\title{
ASSESSMENT OF RESPONSE REDUCTION FACTORS OF REINFORCED CONCRETE BUILDINGS USING RESPONSE SPECTRUM ANALYSIS
}

\author{
by \\ Natalie Simone Bryan, \\ B.Sc. Mechanical Engineering, University of the West Indies, Trinidad, 2000 \\ A master's research project \\ presented to Ryerson University \\ in partial fulfillment of the \\ requirements for the degree of \\ Master of Engineering \\ in the program of \\ Civil Engineering \\ Toronto, Ontario, Canada, 2017 \\ CNatalie Bryan, 2017
}




\section{AUTHOR'S DECLARATION}

I hereby declare that I am the sole author of this MRP. This is a true copy of the MRP, including any required final revisions.

I authorize Ryerson University to lend this MRP to other institutions or individuals for the purpose of scholarly research.

I further authorize Ryerson University to reproduce this MRP by photocopying or by other means, in total or in part, at the request of other institutions or individuals for the purpose of scholarly research.

I understand that my MRP may be made electronically available to the public. 


\section{ABSTRACT \\ Assessment of response reduction factors of reinforced concrete buildings using response spectrum analysis, Natalie Bryan, Civil Engineering, 2017, Ryerson University.}

This study provides an in-depth comparative review of the response reduction factors per NBCC 2015 code used to reduce the elastic response of the structure. An assembly of eight (8) reinforced concrete buildings of which four (4) different Seismic Force Resisting System (SFRS) types was included. The models were also categorized based on ductility and overstrength characteristics specifically ductile and conventional construction moment frames as well as ductile and conventional construction shear walls. All eight (8) models were analyzed using elastic Response Spectrum Analysis (RSA). Each SFRS was also analyzed as both a 12 storey and 40 storey building in order to explore the effects / restrictions of building height. The Equivalent Lateral Force Procedure was performed on the assembly of models for comparison to determine if the static procedure as per NBCC 2015 provisions resulted in overly conservative or similar results.

The relevant structural response such as base reactions, storey drifts, storey forces, and member forces were recorded and analyzed. 


\section{ACKNOWLEDGEMENTS}

I wish to express my sincere appreciation and thanks to my supervisor, Dr. Reza Kianoush, for his guidance, support and encouragement which made possible the successful completion of this study.

I would also like to acknowledge the following individuals who imparted their vast knowledge and expertise and enriched my experience at Ryerson University: Dr Abrishami, Dr. Hossain and Dr. Amleh.

Most importantly, thanks to my family, especially my mother Thelma Marriott, whose unending love and support made this possible. 


\section{TABLE OF CONTENTS}

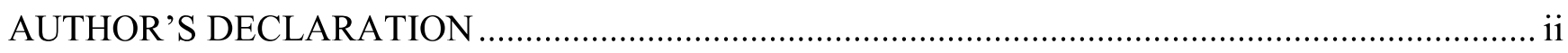

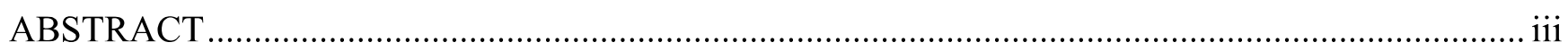

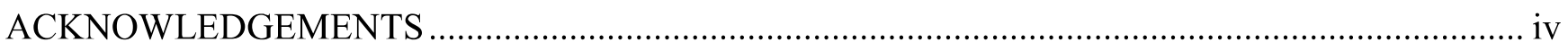

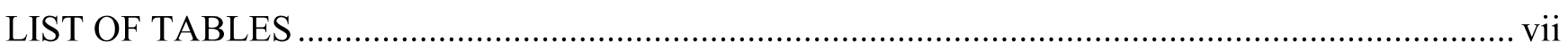

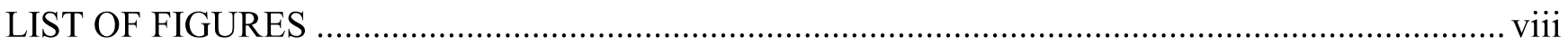

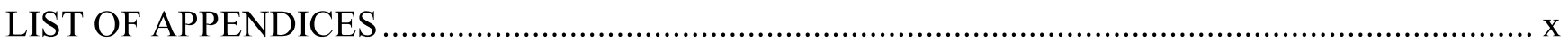

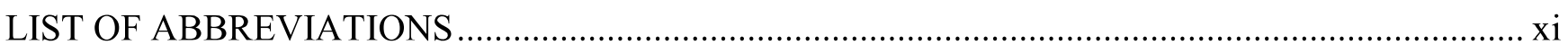

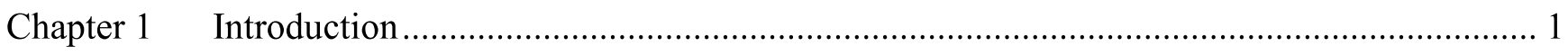

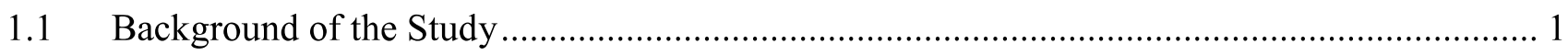

1.1.1 Brief history of the development of the NBCC Seismic code ......................................... 1

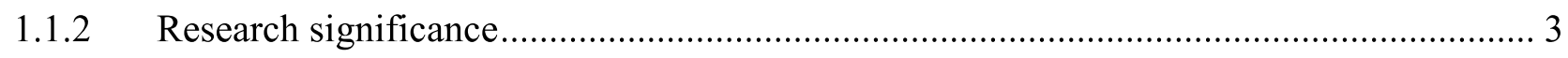

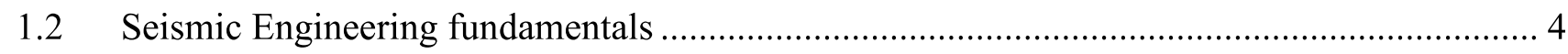

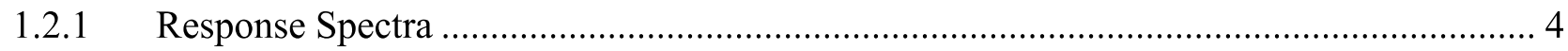

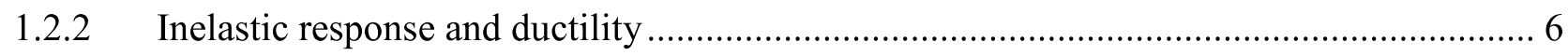

1.2.3 Reinforced concrete ductility and hysteresis .............................................................. 7

1.3 Brief overview of other Structural Analysis methods for seismic design ................................. 8

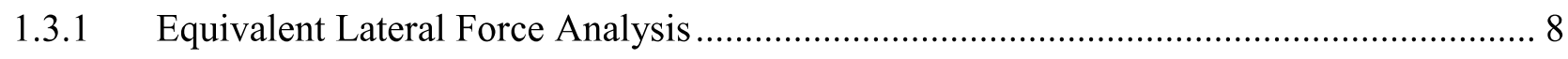

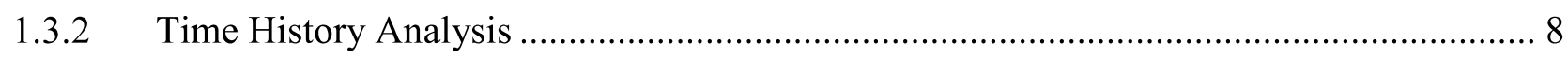

Chapter 2 Objectives, Case study outline and Methodologies ........................................................ 9

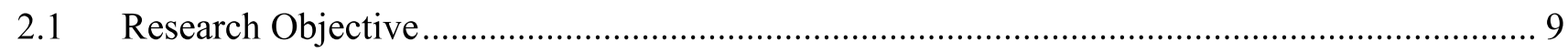

2.2 Research Methodology / Case Study Outline of selected SFRS .............................................. 9

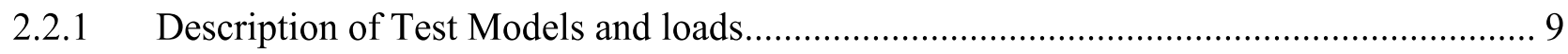

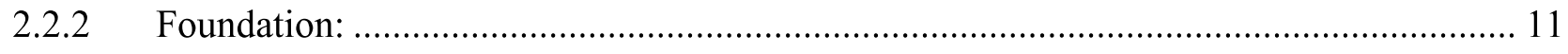

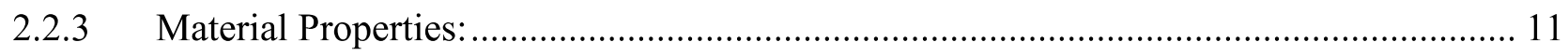




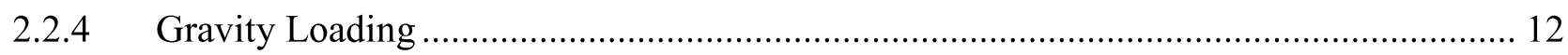

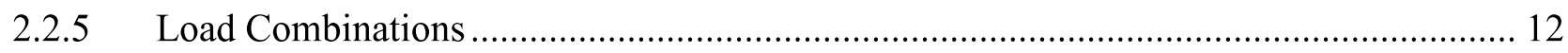

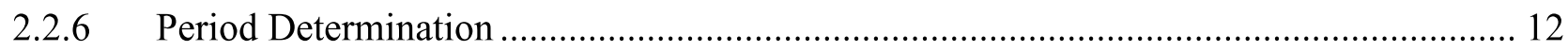

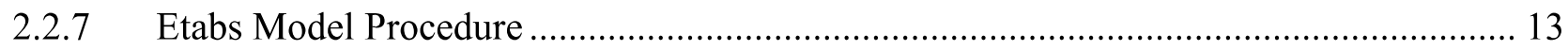

Chapter 3 Review of selected Literature and international Seismic codes on Response Reduction Factors $\quad 15$

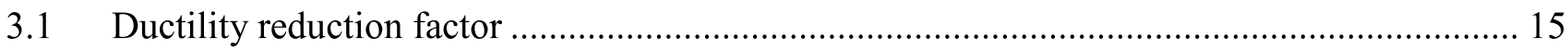

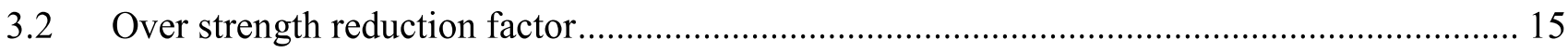

3.3 Comparison of International code provisions for reduction factors with the NBCC 2015 …. 16

3.3.1 Response Reduction Factor as per Mexico City Building code (2004 Building Code) ... 16

3.3.2 Response Reduction Factor as per IBC/ASCE-07 Seismic ……………......................... 17

3.3.3 Response Reduction Factor as per Eurocode .............................................................. 18

3.3.4 Response Reduction Factor in Japanese design code .................................................... 19

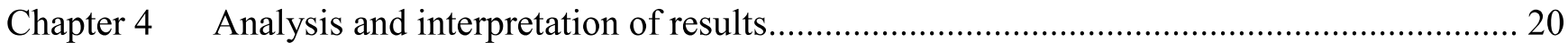

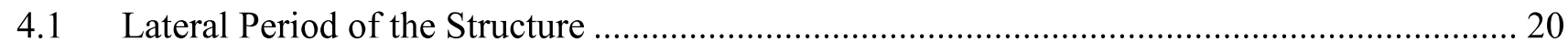

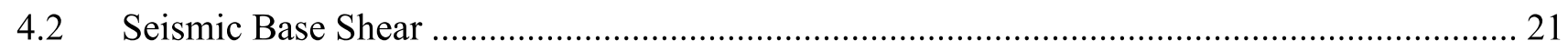

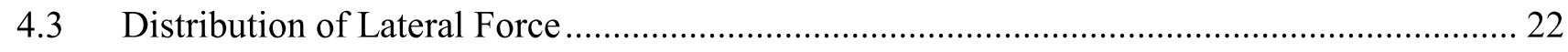

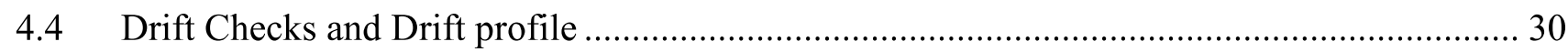

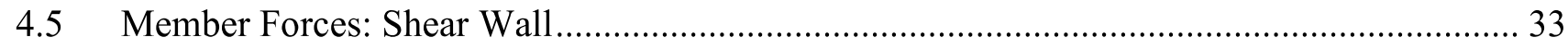

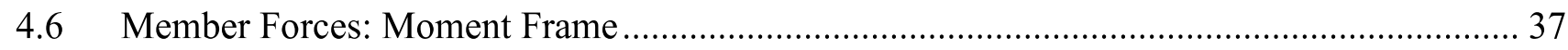

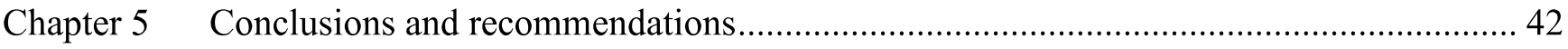

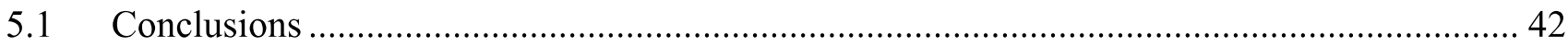

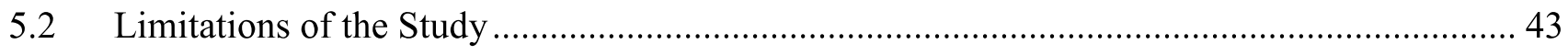

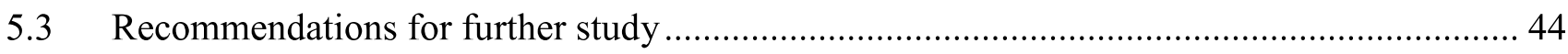

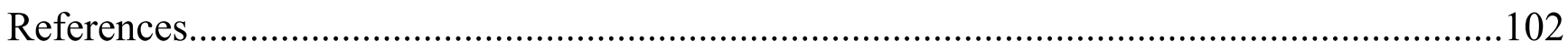




\section{LIST OF TABLES}

Table 1: Summary of signification changes per issued NBCC code

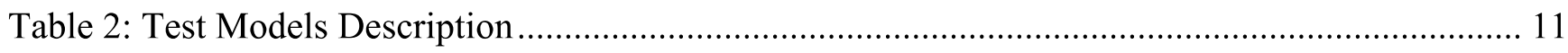

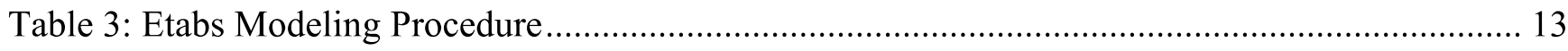

Table 4: Design and detailing provisions of selected Concrete SFRS [13] .......................................... 14

Table 5: Derivation of overstrength-related force modification factors for reinforced concrete seismic

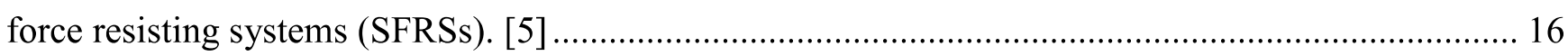

Table 6: Force modification factors per Mexico City Building Code (2004 Building Code). [10]........ 17

Table 7: Force modification factors per ASCE 7-10 Building Code (2004 Building Code). [11] ......... 18

Table 8: Basic behavior factor, $\mathrm{q}_{\mathrm{o}}$, for systems in regular elevation per Eurocode 8 (EC8). [14] .......... 18

Table 9: $D_{s}$ values for reinforced concrete structures (for steel reinforced concrete structures, subtract

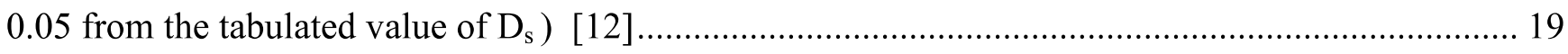

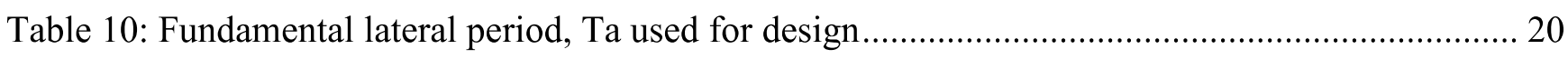

Table 11: Periods and Modal Response Characteristics from Dynamic Analysis.................................. 20

Table 12: Design Base Shear Comparison - Shear Wall (SFRS) .......................................................... 22

Table 13: Design Base Shear Comparison - Moment Frame (SFRS) ................................................. 22 


\section{LIST OF FIGURES}

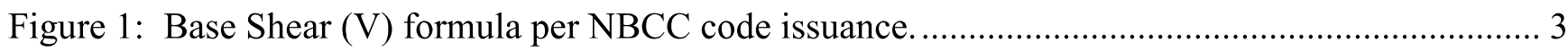

Figure 2: 1990 NBCC code introductions of Force Modification factor / General Ductility (R)........... 4

Figure 3: Acceleration spectrum: El Centro earthquake. [8] ........................................................ 5

Figure 4: Smoothed acceleration spectra for the El Centro earthquake. [8] ……………....................... 5

Figure 5: Concept of response reduction factors used for computing the lateral design force................. 6

Figure 6: Material of the world's tallest building per decade [15] ........................................................ 7

Figure 7: Hysteretic behavior curve representing large energy dissipation [8] ……............................. 7

Figure 8: Base shear formulation per NBCC 2015, where V is the Seismic Base Shear ........................ 8

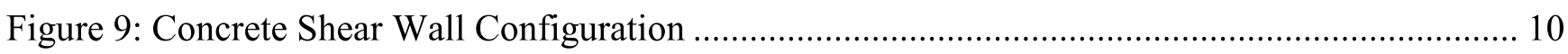

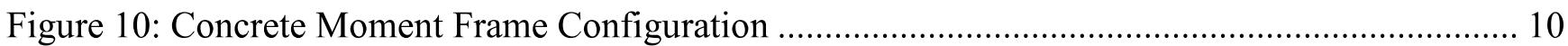

Figure 11: Low Rise Shear Wall SFRS: Lateral Force Distribution - SHEAR …………..................... 23

Figure 12: Low Rise Shear Wall SFRS: Lateral Force Distribution - TORSION .................................... 24

Figure 13: Low Rise Shear Wall SFRS: Lateral Force Distribution - MOMENT ................................. 24

Figure 14: High Rise Shear Wall SFRS: Lateral Force Distribution - SHEAR …………...................... 25

Figure 15: High Rise Shear Wall SFRS: Lateral Force Distribution - TORSION ………………….... 25

Figure 16: High Rise Shear Wall SFRS: Lateral Force Distribution - MOMENT .................................. 26

Figure 17: Low Rise Moment Frame SFRS: Lateral Force Distribution - SHEAR …………................ 26

Figure 18: Low Rise Moment Frame SFRS: Lateral Force Distribution - MOMENT............................ 27

Figure 19: Low Rise Moment Frame SFRS: Lateral Force Distribution - TORSION ........................... 27

Figure 20: High Rise Moment Frame SFRS: Lateral Force Distribution - SHEAR................................ 28

Figure 21: High Rise Moment Frame SFRS: Lateral Force Distribution - TORSION ……………...... 28

Figure 22: High Rise Moment Frame SFRS: Lateral Force Distribution - MOMENT ............................ 29

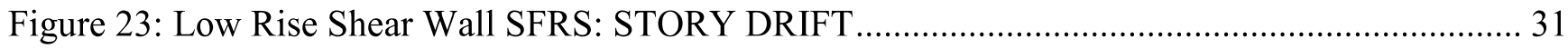

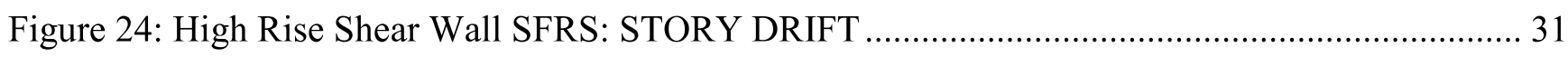

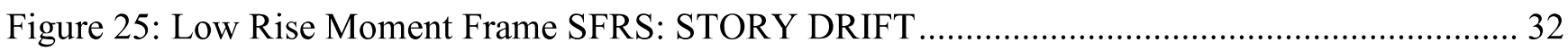

Figure 26: High Rise Moment Frame SFRS: STORY DRIFT ......................................................... 32

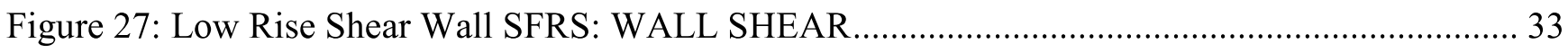

Figure 28: Low Rise Shear Wall SFRS: WALL AXIAL FORCE .................................................. 34

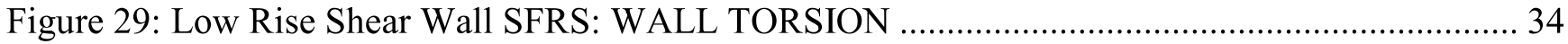

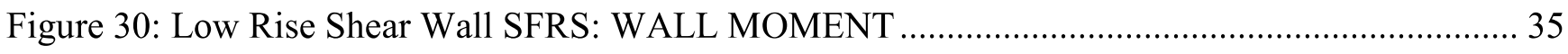

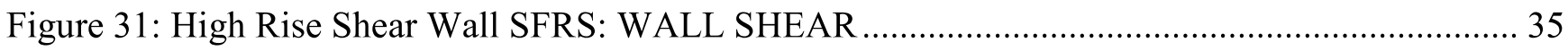


Figure 32: High Rise Shear Wall SFRS: WALL AXIAL FORCE .............................................. 36

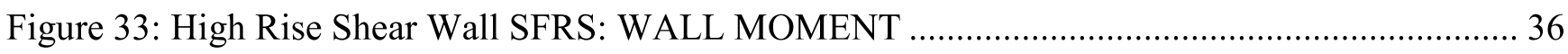

Figure 34: High Rise Shear Wall SFRS: WALL TORSION ...................................................... 37

Figure 35: Low Rise Moment Frame SFRS: BEAM SHEAR .................................................. 38

Figure 36: Low Rise Moment Frame SFRS: BEAM AXIAL FORCE.......................................... 38

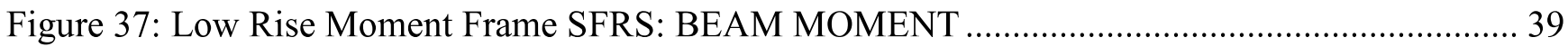

Figure 38: Low Rise Moment Frame SFRS: BEAM TORSION .................................................. 39

Figure 39: High Rise Moment Frame SFRS: BEAM SHEAR ................................................ 40

Figure 40: High Rise Moment Frame SFRS: BEAM AXIAL FORCE ........................................ 40

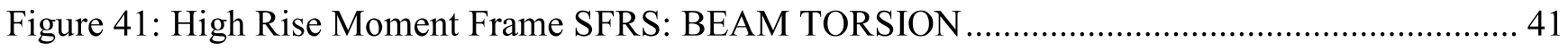

Figure 42: High Rise Moment Frame SFRS: BEAM MOMENT ............................................... 41 


\section{LIST OF APPENDICES}

Appendix A: Plans, Elevations, Material \& Section properties and Loading.................................. 45

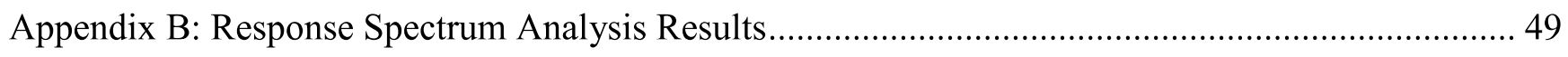

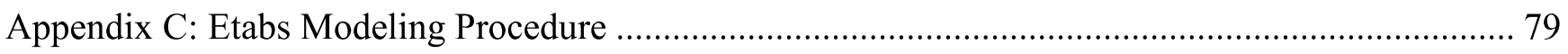

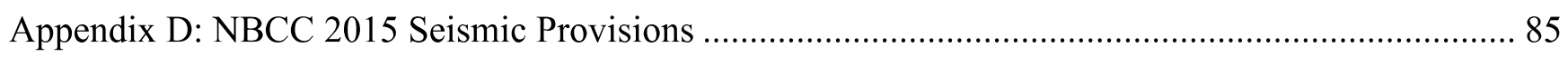

Appendix E: NBCC 2015 Equivalent Lateral Force Procedure Results......................................... 90 


\section{LIST OF ABBREVIATIONS}

Ar Response amplification factor to account for type of attachment of mechanical/electrical equipment.

Ax Amplification factor at level $\mathrm{x}$ to account for variation of response of mechanical/electrical equipment with elevation within the building.

$\mathrm{Bx} \quad$ Ratio at level $\mathrm{x}$ used to determine torsional sensitivity.

B Maximum value of Bxr.

CP Seismic coefficient for mechanical/electrical equipment.

Dnx Plan dimension of the building at level $\mathrm{x}$ perpendicular to the direction of seismic loading being considered.

ex Distance measured perpendicular to the direction of earthquake loading between centre of mass and centre of rigidity at the level being considered.

ELFP Equivalent Later Force Procedure

$\mathrm{Fa}$ Acceleration-related foundation/soil factor.

F(PGA Site coefficient for PGA.

F(PGV) Site coefficient for PGV.

Fs Site coefficient.

$\mathrm{F}(\mathrm{T}) \quad$ Site coefficient for spectral acceleration.

Ft Portion of $\mathrm{V}$ to be concentrated at the top of the structure.

Fv Velocity-related foundation/soil factor.

Fx Lateral force applied to level $\mathrm{x}$.

hv hlV hx The height above the base $(i=0)$ to level $\mathrm{i}, \mathrm{n}$, or $\mathrm{x}$ respectively, where the base of the structure is the level at which horizontal earthquake motions are considered to be imparted to the structure.

hs Interstorey height (hi - hi-1).

IE Earthquake importance factor of the structure.

J Numerical reduction coefficient for base overturning moment.

Jx Numerical reduction coefficient for overturning moment at level $x$.

Level $\mathrm{i} \quad$ Any level in the building, $\mathrm{i}=1$ for first level above the base.

Level $n \quad$ Level that is uppermost in the main portion of the structure. 
Level $\mathrm{x} \quad$ Level that is under design consideration.

Mv Factor to account for higher mode effect on base shear.

Mx Overturning moment at level.

$\mathrm{N} \quad$ Total number of storeys above exterior grade to level $\mathrm{n}$.

PGA Peak Ground Acceleration expressed as a ratio to gravitational acceleration.

PGAref Reference PGA for determining F(T), F(PGA) and F(PGV).

PGV Peak Ground Velocity, in $\mathrm{m} / \mathrm{s}$.

Rd Ductility-related force modification factor reflecting the capability of a structure to dissipate energy through reversed cyclic inelastic behaviour.

Ro Overstrength-related force modification factor accounting for the dependable portion of reserve strength in a structure.

Rs Combined overstrength and ductility-related modification factor.

RSA Response Spectrum Analysis

$\mathrm{S}(\mathrm{T}) \quad$ Design spectral response acceleration, expressed as a ratio to gravitational acceleration, for a period of $\mathrm{T}$.

$\mathrm{Sa}(\mathrm{T}) \quad 5 \%$ damped spectral response acceleration, expressed as a ratio to gravitational acceleration, for a period of $\mathrm{T}$.

SFRS Seismic Force Resisting System(s) is that part of the structural system that has been considered in the design to provide the required resistance to the earthquake forces and effects.

T Period in seconds.

Ta Fundamental lateral period of vibration of the building or structure, ins, in the direction under consideration.

T5 Fundamental lateral period of vibration of the building or structure, ins, in the direction under consideration.

Tx Floor torque at level $\mathrm{x}$.

$\mathrm{V} \quad$ Lateral earthquake design force at the base of the structure.

$\mathrm{Vd} \quad$ Lateral earthquake design force at the base of the structure.

$\mathrm{Ve} \quad$ Lateral earthquake elastic force at the base of the structure.

Ved Lateral earthquake design elastic force at the base of the structure.

VP Lateral force on a part of the structure.

W Dead load plus $25 \%$ of design snow load. 


\section{Chapter 1 Introduction}

\subsection{Background of the Study}

\subsubsection{Brief history of the development of the NBCC Seismic code}

The evolution of the Canadian seismic design codes over the past 70 years has seen many drastic changes. Arguably, the most significant change is the shift from working stress design to ultimate strength design, with load factors and capacity reduction factors, and then to limit states design, with load factors and material resistance factors [6]. Another significant change is the specification of seismic hazard maps and corresponding seismic/site effects across Canada. Table 1 below provides a summary of the significant changes and addition to the National Building Code of Canada regarding the seismic analysis and design of structures.

\section{Table 1: Summary of signification changes per issued NBCC code}

\begin{tabular}{|c|c|}
\hline Year & Significant Addition \\
\hline 1941 & $\begin{array}{l}\text { The first National Building Code (NBC), which contained seismic design provisions in an appendix } \\
\text { (NRCC 1941) [6], was published (Mitchell d et al, 2010) [6] }\end{array}$ \\
\hline 1953 & Introduction of first Seismic zoning map \\
\hline 1960 & Suggested consideration of torsional effects, with no specific guidance provided. \\
\hline 1965 & $\begin{array}{l}\text { Introduction of Importance factor, a foundation factor and consideration for torsion. Ultimate } \\
\text { strength permitted as an alternative method based on the ACI code }\end{array}$ \\
\hline 1970 & Development of truly probalistic seismic zoning map \\
\hline 1975 & $\begin{array}{l}\text { Permitted the use of dynamic analysis as an alternative procedure. A response spectrum compatible } \\
\text { with that proposed by Newmark et al. (1973) with 5\% damping was adopted for the dynamic analysis } \\
\text { that was scaled to the design ground acceleration, , A, equal to } 0,0.02 \mathrm{~g}, 0.04 \mathrm{~g} \text {, and } 0.08 \mathrm{~g} \text { for zones } 0 \text {, } \\
1,2 \text {, and } 3 \text {, respectively. [6] }\end{array}$ \\
\hline 1977 & $\begin{array}{l}\text { A key change in the dynamic analysis design procedure was the introduction of a minimum base } \\
\text { shear equal to } 90 \% \text { of the base shear determined from the static analysis procedure, to limit the } \\
\text { difference between the base shears determined from static and dynamic analyses. }\end{array}$ \\
\hline 1980 & $\begin{array}{l}\text { Introduction of SI Units. Proposal of a procedure for the determination of the structural eccentricity, } \\
\text { e, for each floor level in a structure. }\end{array}$ \\
\hline
\end{tabular}


1985 New seismic zoning maps, based on the point source model developed by Cornell (1968) [6], were introduced in 1985 (NRCC 1985) [6]. Introduction of the acceleration-velocity ratio and its influence of the period of the structure. Hence the spectral shape varies geographically in different regions of the country. Also, this was the first time that the code allowed the building period obtained from modal analysis. [6]

1990 Replacement of the $\mathrm{K}$ factor by the force modification factor $\mathrm{R}$. The $\mathrm{R}$ factor reflecting the ability of the structure to dissipate energy through inelastic behaviour.

1995 The three major changes to the 1995 NBCC (NRCC 1995) were the additional R factors, new expressions for building periods, and new torsional eccentricity expressions. Additional lateral load resisting systems introduced include nominally ductile and ordinary steel plate shear walls $(\mathrm{R}=3$ and 2 , respectively), ductile coupled walls $(\mathrm{R}=4)$, and reinforced masonry walls with nominal ductility $(\mathrm{R}=2)$. [6]

2005 The uniform hazard spectrum (UHS) approach (NEHRP 1997) was adopted essentially giving sitespecific response spectral accelerations for numerous locations in Canada (Adams and Atkinson 2003). These spectral accelerations have a probability of exceedance of $2 \%$ in 50 years (2475-year return period). Dynamic analysis approach became the preferred method of analysis and must be used for structures with certain irregularities. Introduction of two separate force modification factors, the ductility-related force modification factor, $\mathrm{Rd}$, reflects the capability of a structure to dissipate energy through inelastic behaviour while the overstrength-related force modification factor, Ro, accounts for the dependable portion of reserve strength in a structure. [6]

2010 The values for the UHS for all but western localities were recalculated using an improved fit to the ground motion relations used in 2005. In general short-period hazard in low seismic zones were slightly reduced though long-period hazard increased slightly (e.g., Toronto).

2015 Flexible Diaphragms - Buildings with large footprints with flexible steel deck or wood panel diaphragms. Includes design specifications that account for effect of diaphragm flexibility on the period and increased ductility demand on lateral force resisting system. Seismic Isolation Introduces requirement and guidance for three-dimensional non-linear dynamic analysis. Guidance on designing seismically isolated structures and modelling supplementary energy dissipation devices. 


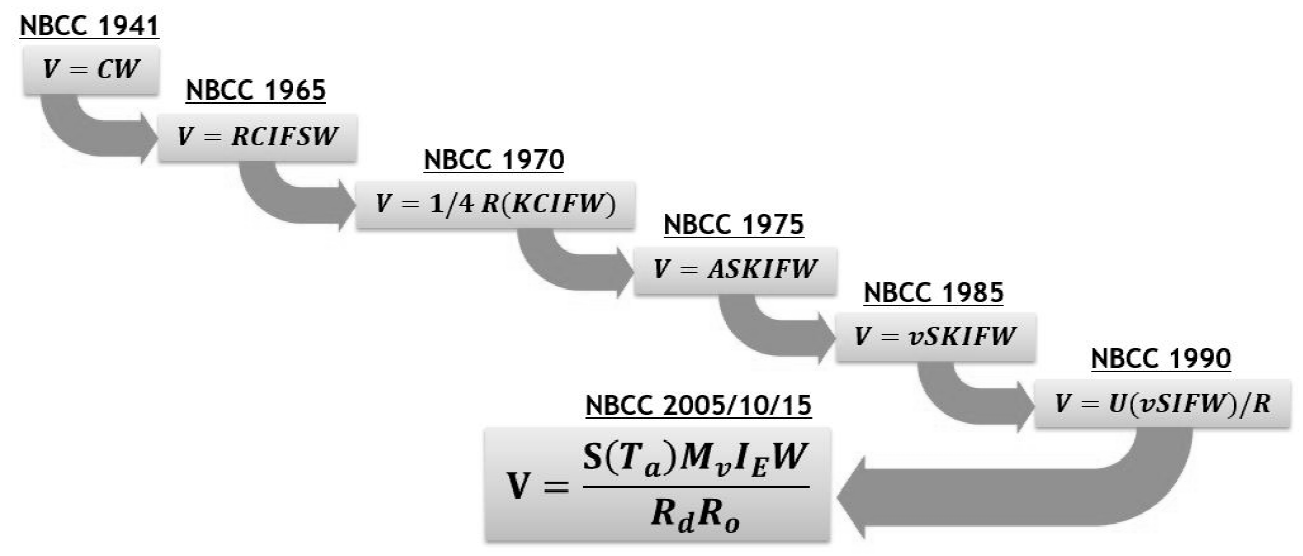

Figure 1: Base Shear (V) formula per NBCC code issuance.

\subsubsection{Research significance}

The general approach of reducing the seismic forces using a reduction factor to generate the design forces remains the predominant concept in seismic design and incorporated in most if not all international codes. These reduction forces are based on rigorous mathematical analysis, experimentation, past building performance among other data analysis. However, the calibrations of these factors are empirical and the values of which have significant influence on the seismic forceresisting system (SFRS) design. There is little evidence that this approach is likely to change in the near future and so further in-depth research into the calibration of these force reduction factors and their impact on the overall SFRS design remains relevant and necessary. This paper will focus on the latter objective as it delves into four different categories of SFRS based on the NBCC 2015 code and how the different $\mathrm{R}$ values of the assigned systems affect various building response and structural member sizes.

The introduction of the ductility and overstrength factors in seismic design results in a more efficient design as the ability of a structure to dissipate energy through inelastic deformation increases its lateral load resistance capability hence reducing the base shear V, applied in structural analysis. As previously mentioned, the introduction of the Force Modification factor/General Ductility (R) factor to replace the K factor was first introduced to the NBCC code in 1990, with structures assigned to three categories, see Figure 2. A ductile moment-resisting frame per 1990 NBCC code prescribed requirements was assigned a value of 4.0 , essentially reducing the idealized elastic base shear by $75 \%$. This demonstrates the significance of a structure's ductility and overstrength in determining its seismic capacity. This paper will attempt to explore the quantitative effects of the code prescribed Force Modification Factors $\left(R_{d}\right.$ and $\left.R_{o}\right)$ on structural seismic response based on linear dynamic response 
spectrum analysis. Such effects are to include force-displacement relationship, distribution of lateral force, natural period, and sensitivity to variations in height, and performance and overall capacity.

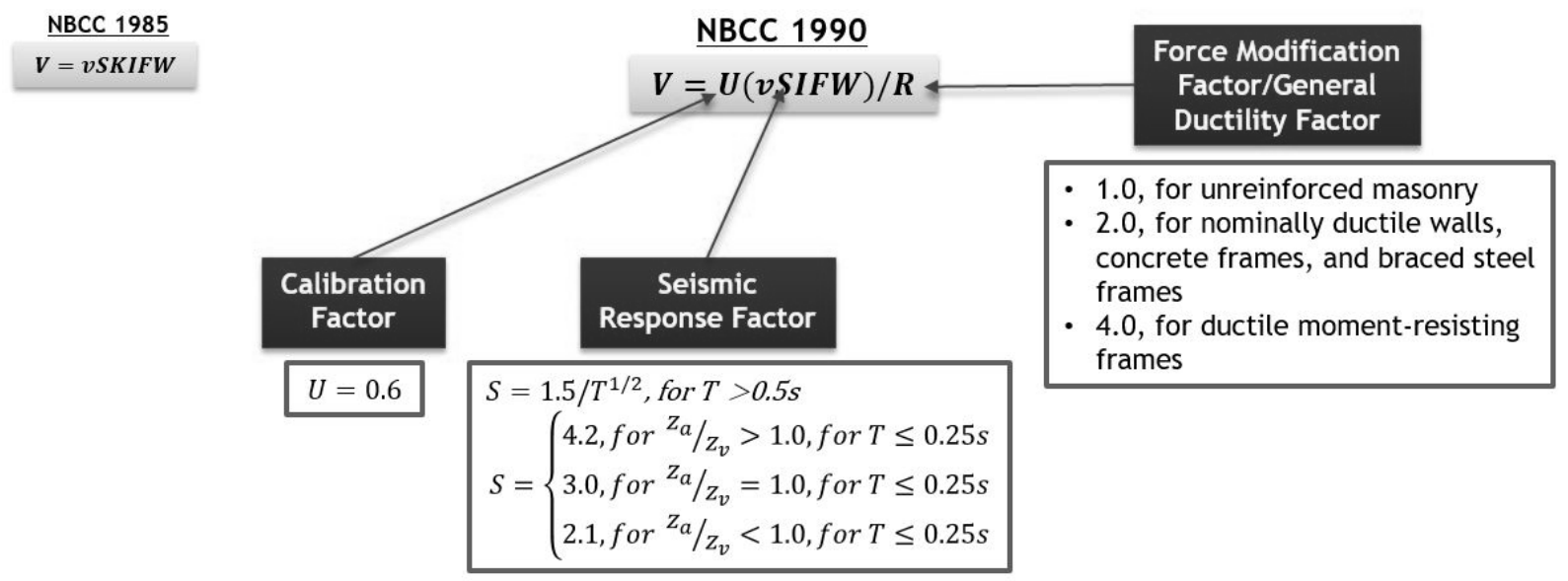

Figure 2: 1990 NBCC code introductions of Force Modification factor / General Ductility (R).

\subsection{Seismic Engineering fundamentals}

\subsubsection{Response Spectra}

The response spectrum analysis (RSA) is a linear elastic dynamic analysis of structures. Literature defines RSA as a graphical representation of the dynamic earthquake-related response such as acceleration, velocity, displacement, etc., of a structure having a broad range of periods subjected to a common lateral seismic motion at the base [8]. Accelerograms, such as shown in Figure 3, records the maximum dynamic response, acceleration in this case, for various levels of damping for a given earthquake motion. The erratic nature of ground shaking leads to a response that is very erratic in that a slight change in the natural period of vibration brings about a very large change in response. Hence, to achieve a smooth spectral shape (design spectra), several ground motions are averaged and normalized based on a probalistic model, see Figure 4. Realistically, very few structures vibrate as a single-degreeof-freedom system, however, the principles of dynamic modal analysis, allow a reasonable approximation of the maximum response of a multi-degree-of-freedom oscillator, such as a multistory building, if many specific conditions are met. The procedure involves dividing the total response into several natural modes, modeling each mode as an equivalent single degree-of-freedom oscillator, determining the maximum response for each mode from a single-degree-of-freedom response spectrum and then estimating the maximum total response by statistically summing the responses of the individual modes. The provisions does not require consideration of all possible modes of vibration for 
most buildings because the contribution of the higher modes (lower periods) to the total response is relatively minor. This concept is generally referred to as the participation factor [8].

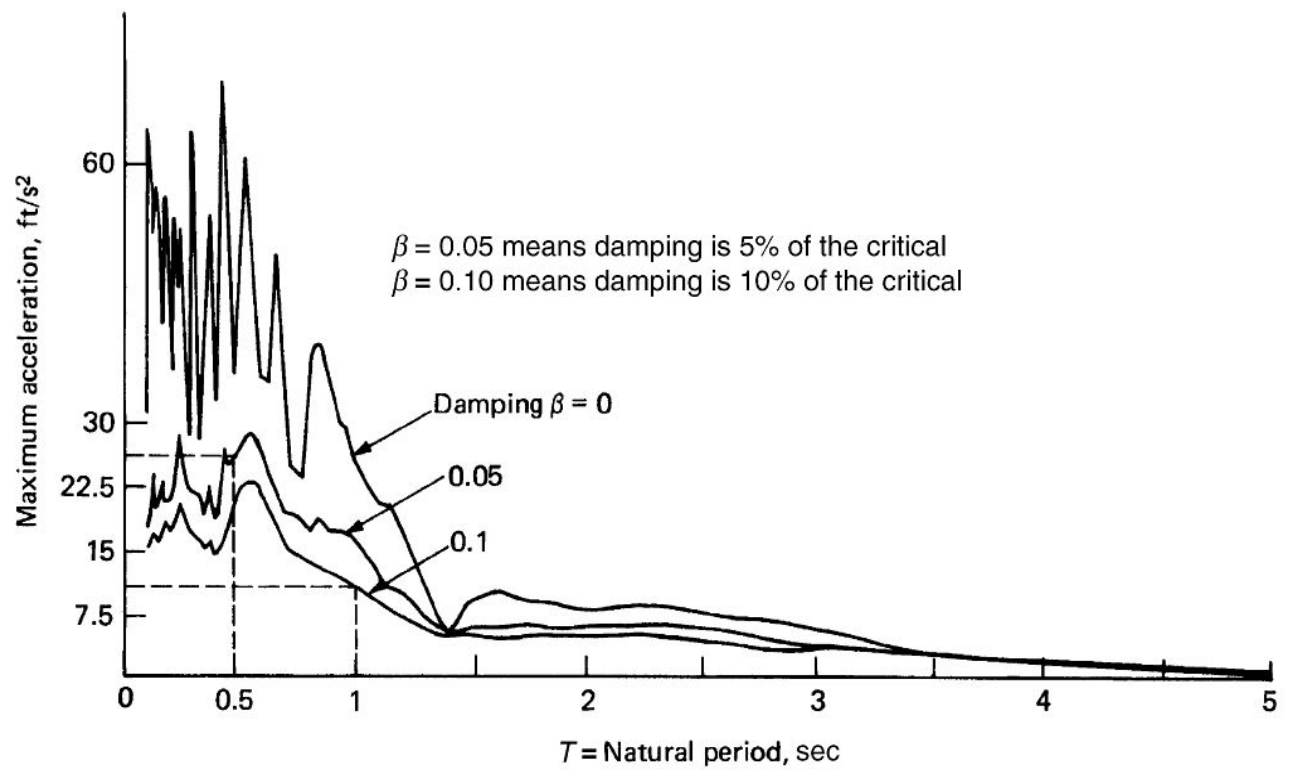

Figure 3: Acceleration spectrum: El Centro earthquake. [8]

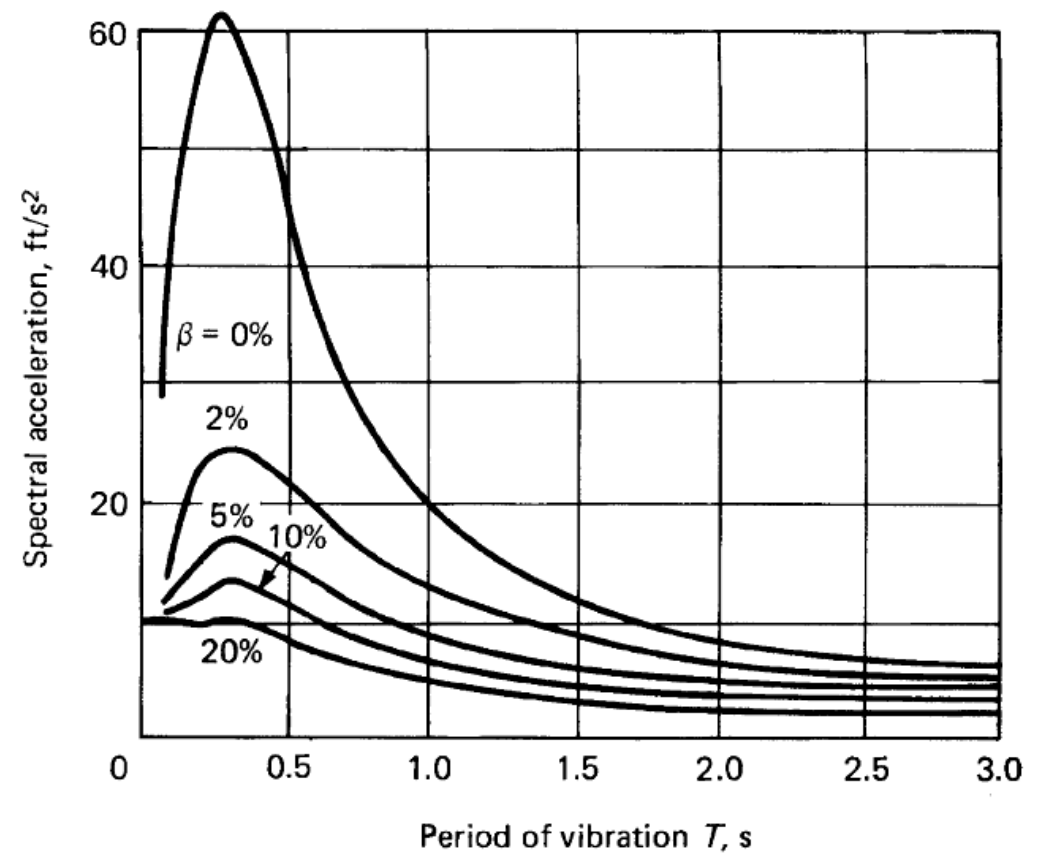

Figure 4: Smoothed acceleration spectra for the El Centro earthquake. [8] 


\subsubsection{Inelastic response and ductility}

Response reduction factors such as $R_{d}$ and $R_{o}$ (NBCC 2015) are essentially used to reduce the idealized linear elastic response of a structure. Generally, the three response reduction factors considered in seismic design are due to the ductility of the structure, the various redundancies or options for the load path to foundation and the sources of overstrength incorporated in the design of the structure. The overstrength and redundancy are considered as one component while the damping and ductility are also considered as one component, hence the use of $\mathrm{R}_{\mathrm{d}}$ and $\mathrm{R}_{\mathrm{o}}$. Figure 5 gives a simplified graphical representation based on the lateral load-displacement relationship. The idealized elastic load, $F_{e l}$ is reduced to the design force due to these above mentioned factors. The combined reduction factor $R_{d} R_{0}$ is an empirical numerical value intended to account for damping, overstrength, redundancy and ductility inherent in the structural system at forces large enough to cause displacement beyond the yield displacement, $\Delta_{\mathrm{y}}$ but less that the ultimate load displacement $\Delta_{\max }$ of the system. The general concept is that a well detailed seismic framing system can sustain large inelastic deformations without collapse (ductile behavior) and develop lateral strength in excess of the design strength (overstrength). These concepts will be further explored in Chapter 3.

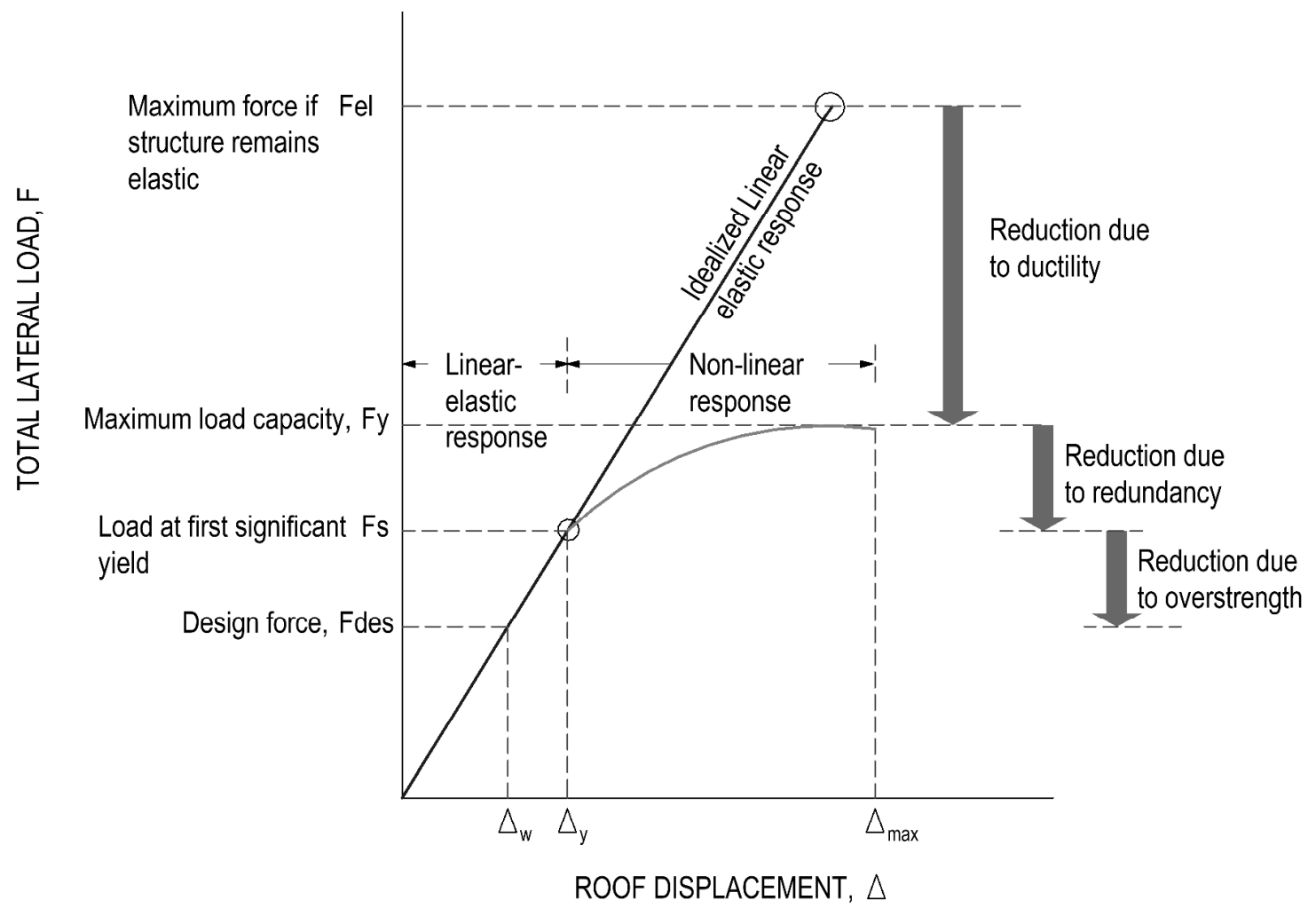

Figure 5: Concept of response reduction factors used for computing the lateral design force. 


\subsubsection{Reinforced concrete ductility and hysteresis}

Over the past four decades, concrete has emerged as the most commonly used material in the construction of tall buildings, see Figure 6 . For this reason, among other factors, concrete SFRS systems were selected for this study. In seismic design, reinforced concrete structures with well detailed and designed members and joints must be able to sustain large deformations without losing their vertical load carrying capacity. When the structure is able to respond inelastically (ductile), it must do so for the full duration of the seismic event, implying many inelastic excursions in each direction [8]. The force-displacement diagram for reinforced concrete, in the inelastic range, follows a hysteresis loop as opposed to the idealized elastic/perfectly plastic (elastoplastic) behavior. Essentially, the hysteresis loop, see Figure 7, represents the ductile behavior of well designed reinforced concrete in that there is excessive strength degradation with increasing displacement or cyclic loading.

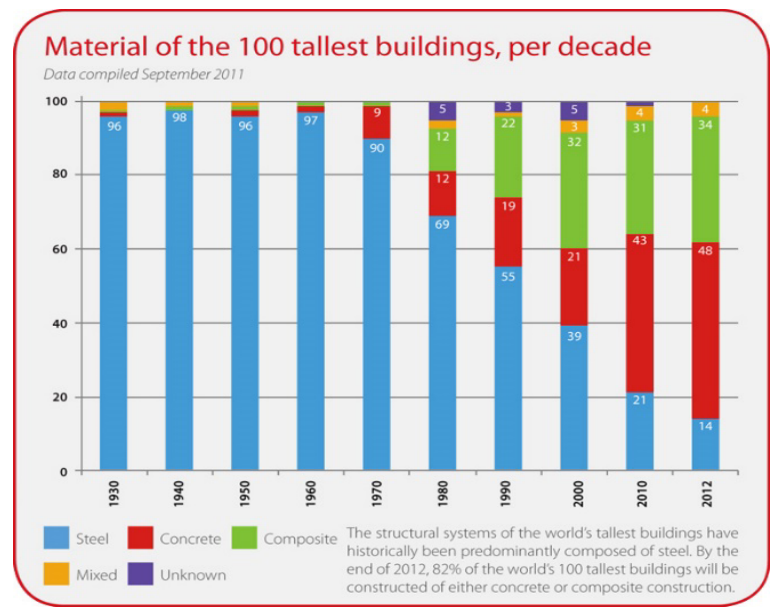

Figure 6: Material of the world's tallest building per decade [15]

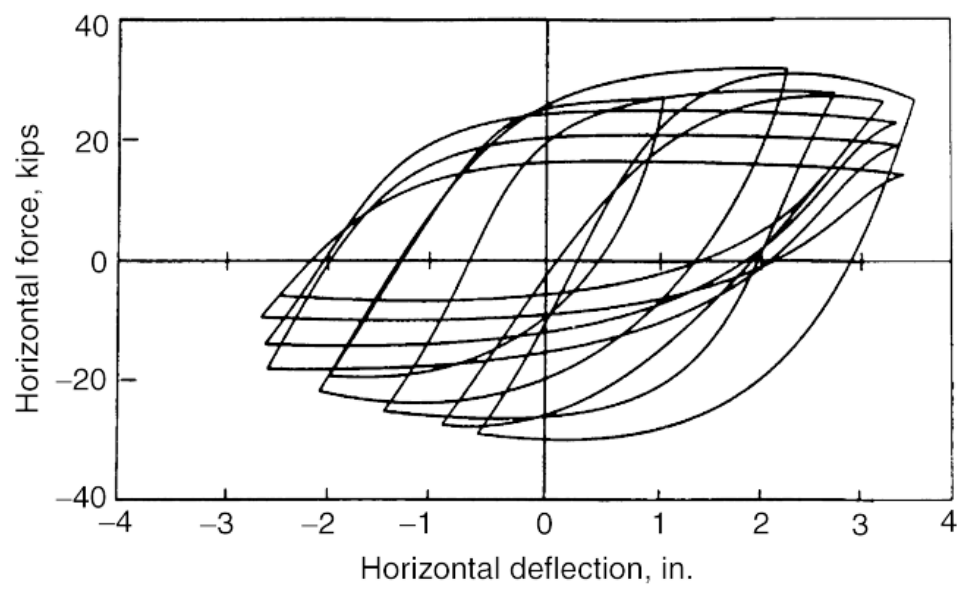

Figure 7: Hysteretic behavior curve representing large energy dissipation [8] 


\subsection{Brief overview of other Structural Analysis methods for seismic design}

\subsubsection{Equivalent Lateral Force Analysis}

The equivalent lateral force procedure is allowed for the following cases in the NBCC 2015:

i. In cases where $I_{\mathrm{e}} F_{\mathrm{a}} S_{\mathrm{a}}(0.2)$ is less than 0.35 ,

ii. Regular structures, less than $60 \mathrm{~m}$ in height and have a fundamental lateral, Ta period less than $2 \mathrm{~s}$ in each of two orthogonal directions; or

iii. Structures with structural irregularity, of type $1,2,3,4,5,6$ or 8 , that are less than $60 \mathrm{~m}$ in height, have a fundamental lateral period less than $0.5 \mathrm{~s}$ in each of two orthogonal directions.

\section{$\underline{\text { NBCC } 2015}$}

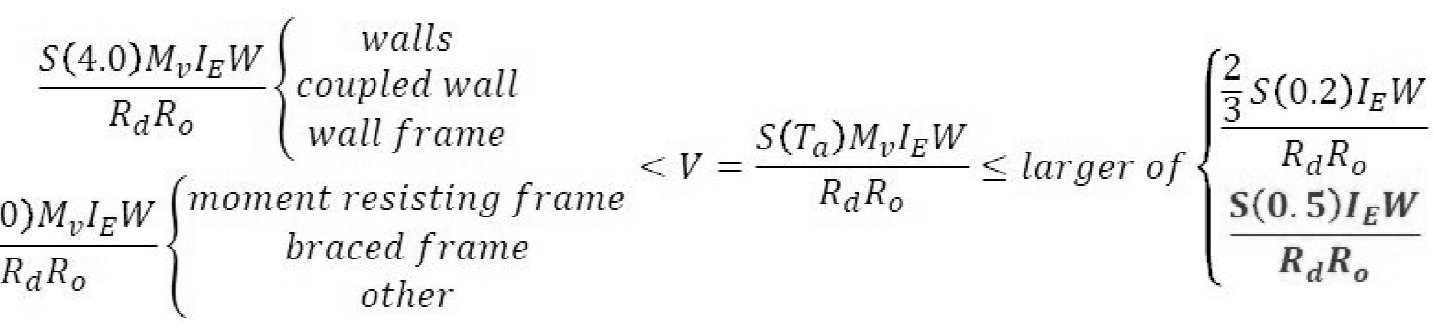

Figure 8: Base shear formulation per NBCC 2015, where V is the Seismic Base Shear

\subsubsection{Time History Analysis}

Unlike Response Spectrum Analysis, time history methods are applicable to both elastic and inelastic analysis. The main distinction between linear elastic response method and Time History Analysis (linear and non-linear) is the assumption of the structures stiffness over time. In the former, the stiffness is considered to be constant over the entire duration of the seismic event, while the latter assumes the stiffness is constant only for a short time $\partial_{\mathrm{t}}$. For Time History Analysis, the initial stiffness is modified over time to account for cracking, deflection, formation of plastic hinges, etc.

The Numerical Integration Time History Method, involves the determination of the response of a structural model to a specified earthquake ground motion accelorogram through the numerical integration of the equations of motion. The primary advantage of this method to the Modal Response Spectrum Method is that the various response parameters are obtained as time histories providing information on the time-wise fluctuation of the state of deformation of the structure [8].

However, there are several disadvantages as well including the complexity and computing time /costs as well as the heavy reliance of user assumptions can lead to significant uncertainties and errors. Hence this method is rarely used for the analysis of ordinary building structures. 


\section{Chapter 2 Objectives, Case study outline and Methodologies}

\subsection{Research Objective}

The main research objective is to compare the NBCC code prescribed response reduction factors used for ductile versus conventional construction reinforced concrete SFRS, based on selected building response. The specific objectives of the study are:

1. Conduct Response analysis on 8 different building structures of varying height, ductility and overstrength modification factors using 3-dimensional mathematical models in Etabs software.

2. Conduct Equivalent Lateral force procedure on all 8 structures and compare the results obtained from the dynamic analysis.

3. Evaluate structural response such as base reactions (seismic base shear), story forces, story drifts and member forces.

4. Review overall building drifts per code provisions.

\subsection{Research Methodology / Case Study Outline of selected SFRS}

\subsubsection{Description of Test Models and loads}

An assembly of 8 test models was used in this study. The models were categorized based on height (Low-rise/High-rise), SFRS type (Shear wall/Moment Frame) and SFRS detailing and design (Ductile/Conventional Construction). The low-rise models are 12 storeys high, while the high-rise models are 40 storeys. The building site was located in Montreal, Quebec. The basic structural configuration of the concrete shear wall and concrete moment frame is shown in Figure 9 and Figure 10, which show a typical floor plan. All eight buildings have two basement levels, however the basement levels were not considered in the dynamic analysis. They all have a centrally located elevator core. Each floor consists of a $200 \mathrm{~mm}$ thick flat plate with $6 \mathrm{~m}$ interior spans and $5.5 \mathrm{~m}$ end spans. For the moment frame configurations, the columns are all $550 \mathrm{~mm} 5550 \mathrm{~mm}$ with $550 \mathrm{~mm}$ wide $\mathrm{x} 1000 \mathrm{~mm}$ deep beams spanning each bay (interior and exterior). For the shear wall configuration, the thicknesses of all walls are $400 \mathrm{~mm}$. The wall thickness of $400 \mathrm{~mm}$ initially chosen such that it exceeds $1_{\mathrm{u}} / 14=$ $4650 / 14=332 \mathrm{~mm}$ (Clause21.5.3). The core walls extend one storey above the roof at the level forming an elevator penthouse at the upper most level. For all eight test models, the main SFRS is designed to take $100 \%$ of the lateral load, per NBCC 2015 code prescription. The designs of all 8 buildings are essentially symmetric in both orthogonal directions. Hence, for the purpose or clarity, the results in the E-W (x-axis) direction will be reviewed as both orthogonal directions have produced similar results. 

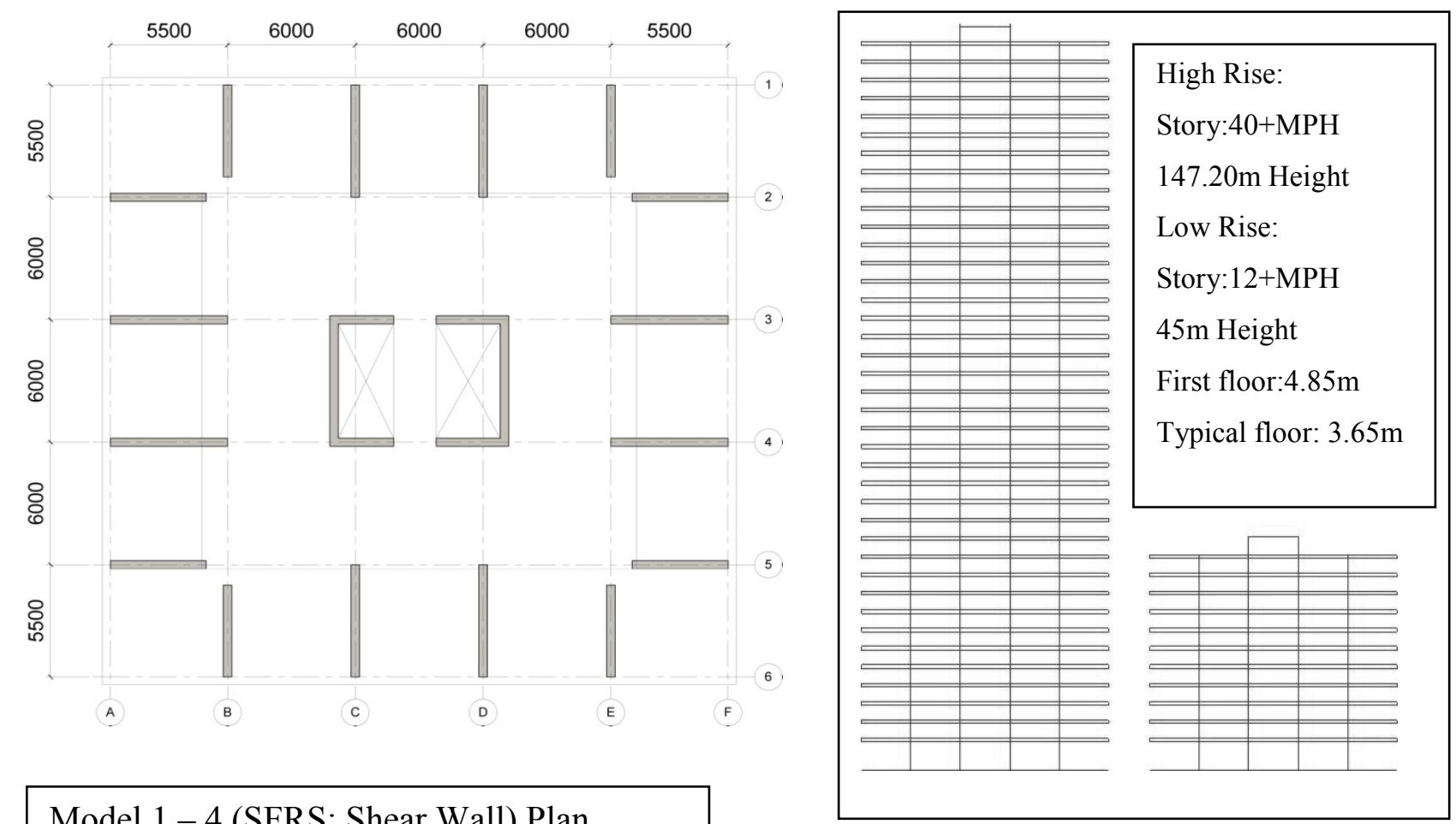

Model 1 - 4 (SFRS: Shear Wall) Plan

$200 \mathrm{~mm}$ Slab. $400 \mathrm{~m}$ thick walls

Figure 9: Concrete Shear Wall Configuration

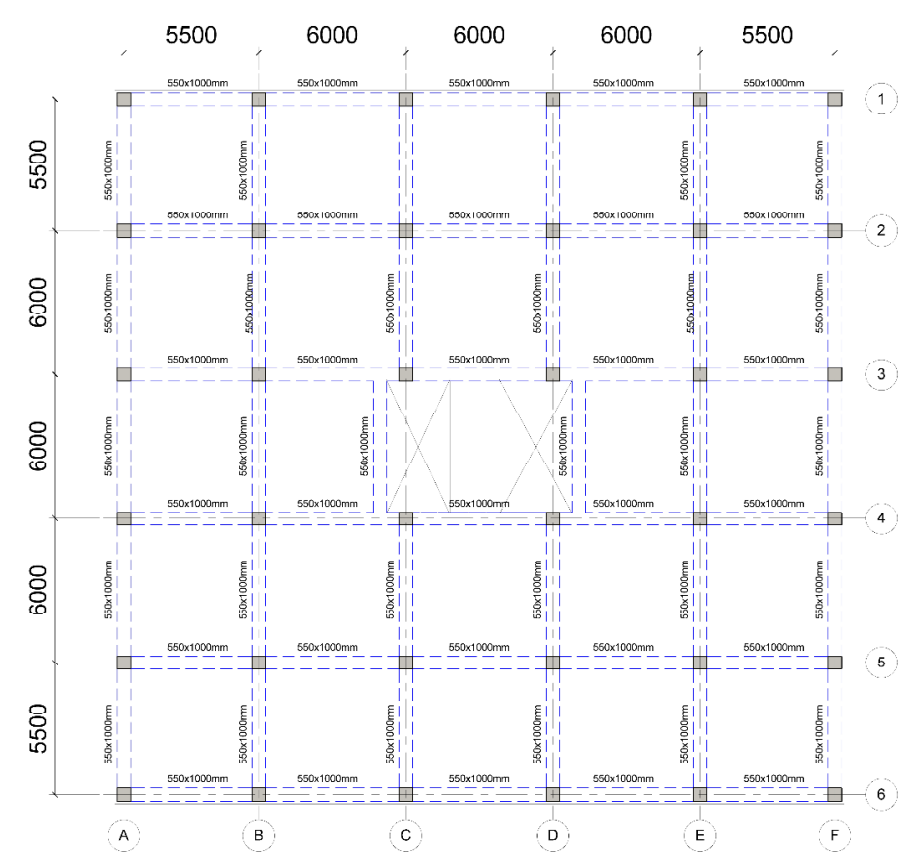

Figure 10: Concrete Moment Frame Configuration

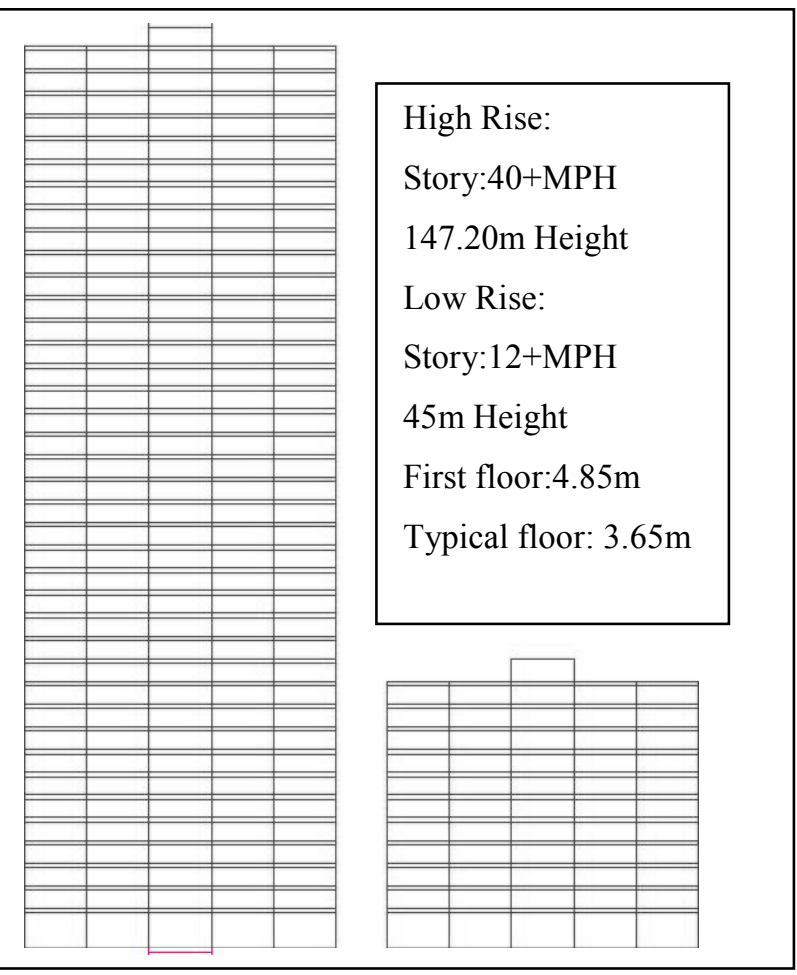

Model 5 - 8 (SFRS: Concrete Moment Frame) Plan

$550 \mathrm{~mm} \times 550 \mathrm{~mm}$ Columns. $550 \mathrm{~mm} \mathrm{~W}$ x $1000 \mathrm{~mm}$ Deep beams 
Table 2: Test Models Description

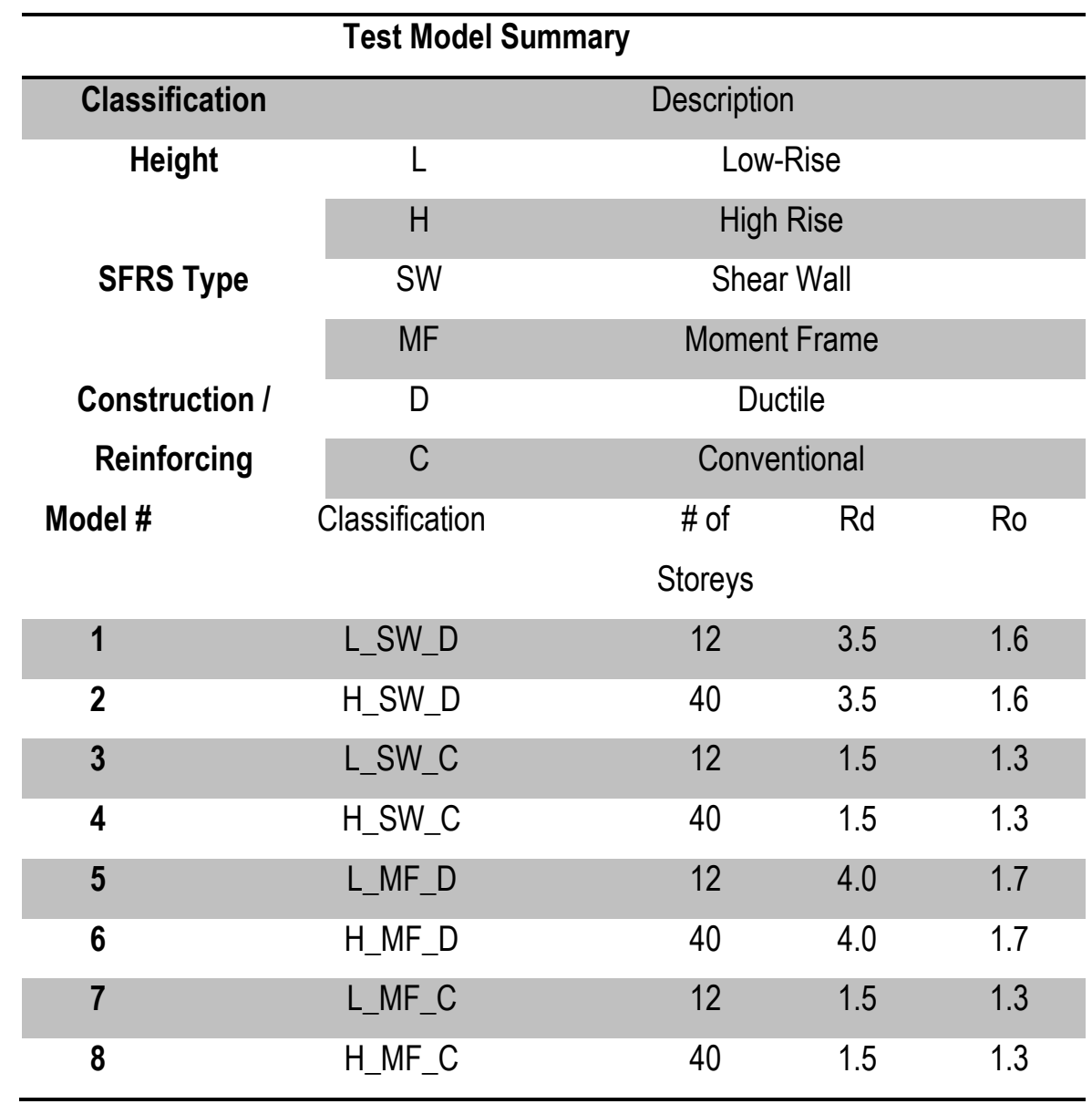

\subsubsection{Foundation:}

The foundation system is not analyzed in this case study, but is assumed that the structure is founded on stiff soil. Each building has 2 basement levels with concrete walls located around the perimeter of the foundations. The site classification is " $\mathrm{D}$ ".

\subsubsection{Material Properties:}

Concrete: Normal density concrete with $\mathrm{f}_{\mathrm{c}}=30 \mathrm{MPa}$.

Reinforcement: $f_{y}=400 \mathrm{MPa}$. 


\subsubsection{Gravity Loading}

Floor Live Load: $\quad 2.4 \mathrm{kN} / \mathrm{m}^{2}$ on typical office floors

$4.8 \mathrm{kN} / \mathrm{m}^{2}$ on $12 \mathrm{~m}$ by $12 \mathrm{~m}$ corridor area around core

Roof Load: $\quad 2.5 \mathrm{kN} / \mathrm{m}^{2}$ full snow load

$1.6 \mathrm{kN} / \mathrm{m}^{2}$ mechanical services loading in $6 \mathrm{~m}$ wide strip over corridor bay

Dead Loads: $\quad$ self-weight of members calculated at $24 \mathrm{kN} / \mathrm{m}^{3}$

$1.0 \mathrm{kN} / \mathrm{m}^{2}$ partition loading on all floors

$0.5 \mathrm{kN} / \mathrm{m}^{2}$ ceiling and mechanical services loading on all floors

$0.5 \mathrm{kN} / \mathrm{m}^{2}$ roofing

\subsubsection{Load Combinations}

The basic strength design load combinations that must be considered are:

1. $1.4 \mathrm{D}$

2. $(1.25 \mathrm{D}$ or $0.9 \mathrm{~d})+1.5 \mathrm{~L}$

3. $(1.25 \mathrm{D}$ or $0.9 \mathrm{~d})+1.5 \mathrm{~S}$

4. $1.4 \mathrm{D}+1.0 \mathrm{E}$

Due to the focus on seismic design, the wind loads were not included in the applied loads and/or load combinations. See Appendix C for detailed lists of principal and companion load combinations.

\subsubsection{Period Determination}

Requirements for the computation of the building periods were followed as outlined in the NBCC 2015 provisions. For the preliminary design, the approximate fundamental lateral period of vibration, Ta, code was calculated as per Cl.4.1.8.1 (7)

For concrete moment frames:

$$
T_{a, c o d e}=0.075\left(h_{n}\right)^{3 / 4}
$$

For Shear Walls:

$$
\text { (2) } \quad T_{a, \text { code }}=0.05\left(h_{n}\right)^{3 / 4}
$$

Where $h_{n}$ is the height above the base in $\mathrm{m}$. This method for determining the approximate period will generally result in periods that are lower (hence, more conservative for use in predicting base shear) than those computed from a more rigorous mathematical model. Therefore, the lateral period of the structure was also determined after performing the Response Spectrum Analysis. Per code provisions, if the building period computed through dynamic analysis is too high, due in part to a variety of 
possible modeling simplifications and assumptions, then the period is given an upper limit as per $\mathrm{Cl}$. 4.1.8.11(3).

For concrete moment frames:

$$
T_{a} \leq 1.5\left(T_{a, c o d e}\right)
$$

For Shear Walls:

(4) $T_{a} \leq 2\left(T_{a, c o d e}\right)$

\subsubsection{Etabs Model Procedure}

The site location of Montreal, Quebec per NBCC 2015 requires dynamic analysis procedure (explored further in Appendix D). Etabs was used as to conduct the elastic dynamic analysis using Response Spectrum. The modeling procedure for Etabs is summarized in Table 3. The detailed Etabs procedure is illustrated in Appendix C.

Table 3: Etabs Modeling Procedure

\section{Etabs Modeling Procedure}

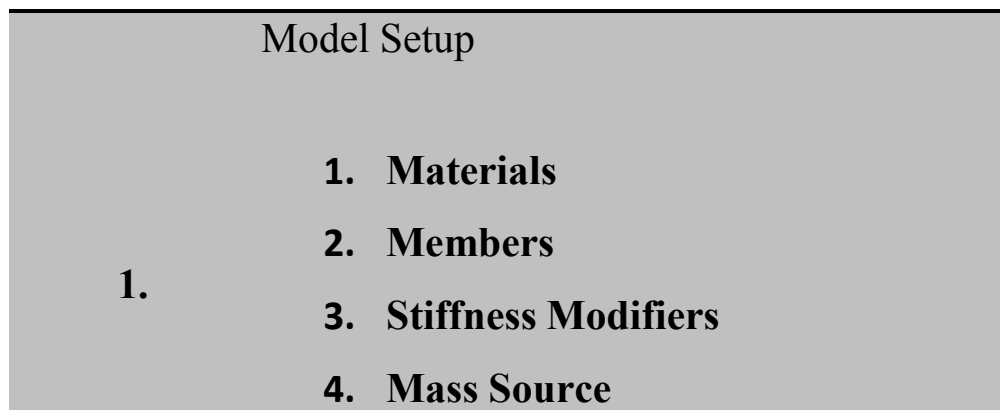

Loads

1. Load Patterns/Cases

2. 2. Floor Loads

3. Lateral Loads

Modeling

1. Slab/Wall Meshing

3. 2. Releasing Frame Elements

3. Coupling Beams

4. Post-Analysis Model Verification 
Table 4: Design and detailing provisions of selected Concrete SFRS [13]

\section{Concrete SFRS}

\begin{tabular}{llll}
\hline Type of SFRS & Rd & Ro & Summary of design and detailing requirements
\end{tabular}

\begin{tabular}{|c|c|c|c|}
\hline $\begin{array}{l}\text { Ductile moment } \\
\text { resisting frames }\end{array}$ & 4.0 & 1.7 & $\begin{array}{l}\text { Beams capable of flexural hinging with shear failure and bar } \\
\text { buckling avoided. Beams and columns must satisfy ductile detailing } \\
\text { requirements. Columns properly confined and stronger than beams. } \\
\text { Joints properly confined and stronger than beams. }\end{array}$ \\
\hline $\begin{array}{l}\text { Conventional } \\
\text { Construction: }\end{array}$ & 1.5 & 1.3 & $\begin{array}{l}\text { Beams and columns must have factored resistances greater than or } \\
\text { equal to factored loads. Columns and beams must satisfy minimum }\end{array}$ \\
\hline $\begin{array}{l}\text { Moment } \\
\text { resisting frames }\end{array}$ & & & $\begin{array}{l}\text { detailing requirements for conventional construction. Closely } \\
\text { spaced hoops required in columns unless factored resistance of } \\
\text { columns greater than factored resistance of beams of if RdRo }=1.3\end{array}$ \\
\hline
\end{tabular}

$\begin{array}{llll}\begin{array}{l}\text { Ductile shear } \\ \text { walls }\end{array} & 3.5 & 1.6 & \begin{array}{l}\text { Walls must be of flexural yielding without local instability, Shear } \\ \text { failure or bar buckling. Walls must satisfy ductile detailing and } \\ \text { ductility requirements. }\end{array} \\ \begin{array}{l}\text { Conventional } \\ \text { Construction: }\end{array} & 1.5 & 1.3 & \text { Walls must have factored resistances greater than or equal to } \\ \text { Shear walls } & & \text { factored loads. Factored shear resistance must exceed shear } \\ & \text { corresponding to factored flexural resistance or shear corresponding } \\ & \text { to RdRo }=1.3 . \text { Walls must satisfy minimum detailing requirements } \\ & \text { for conventional construction and minimum ductility requirements. }\end{array}$




\section{Chapter 3 Review of selected Literature and international Seismic codes on Response Reduction Factors}

\subsection{Ductility reduction factor}

Ductility is essentially the measure of the ability to deform beyond the yield limit without significant loss of strength. This inelastic deformation absorbs and dissipates energy imposed on a structure such as the cyclic dynamic action of a seismic event. The overall ductility of a structure depends on the ductile properties of the material, structural elements and the design of the connections between both the structural and non-structural elements. The physical manifestation of the ductility of the material is expressed as a function of the stress-strain curve, for the structural element with the moment-curvature diagram and for the structural assembly with the force-displacement diagram.

The ductility-related force modification factor, $R_{d}$, was first explicitly introduced in the 2005 NBCC codes, however it is essentially corresponds to the R factor used in previous NBCC code. It was the 2005 code that introduced two separate force modification factors, one accounting for the ductility, $R_{d}$ and the other for the overstrength, $R_{o}$ of the structure [5]. The factor ranges from 1 for brittle systems such as unreinforced masonry to 5.0 for ductile moment-resisting steel frames. The specified ductility and energy absorption capabilities of the structure are designed per strict specification of the NBCC code in accordance with the CSA standard. For example, in reinforced concrete ductile coupled wall design, the coupling beam must be able to resist a minimum $66 \%$ of the base overturning moment by the axial tension and compression forces resulting from shear in the coupling beam. This example of capacity design is used for providing significant yielding in the critical elements (such as coupling beams), while limiting inelastic demands in the other elements (such as shear walls), hence avoiding all potential brittle failure modes. Table 4 illustrates the design and detailing of selected reinforced concrete SFRS.

\subsection{Over strength reduction factor}

The inclusion of an explicit overstrength -related force modification factor, $\mathrm{R}_{\mathrm{o}}$, was first introduced in the 2005 NBCC code to account for the inherent reserve strength due to a number of design factors. As explored in the report by Mitchell et al (2005) [5], $\mathrm{R}_{\mathrm{o}}$ is a product of a four (4) different $\mathrm{R}$ factors accounting for the structural member size, $R_{\text {size }}$, design and material resistance factors, $R \Phi$, the

underestimation of the minimum specified yield strength versus the actual yield strength, $R$ yield, 
the ability of strain hardening to develop in the material, $R_{\mathrm{Sh}}$, and the additional resistance that can be developed before a collapse mechanism is formed in the structure, $R$ mech. Table 5 lists the values assigned to the aforementioned overstrength factors for the different reinforced concrete SFRS's.

$$
R_{o}=R_{\text {size }} R_{\Phi} R_{y i e l d} R_{s h} R_{m e c h}
$$

Table 5: Derivation of overstrength-related force modification factors for reinforced concrete seismic force resisting systems (SFRSs). [5]

\begin{tabular}{|c|c|c|c|c|c|c|c|}
\hline Type of SFRS & $R_{\text {size }}$ & $\boldsymbol{R} \Phi$ & $R_{\text {yield }}$ & $\boldsymbol{R}_{\text {Sh }}$ & $R_{\text {mech }}$ & $\boldsymbol{R}_{\mathbf{O}}$ & $\begin{array}{l}\text { NBCC } \\
2015 \\
R_{0}\end{array}$ \\
\hline Ductile moment-resisting frames & 1.05 & 1.18 & 1.05 & 1.25 & 1.05 & 1.71 & 1.7 \\
\hline $\begin{array}{l}\text { Moderately ductile moment- } \\
\text { resisting frames }\end{array}$ & 1.05 & 1.18 & 1.05 & 1.10 & 1.00 & 1.43 & 1.4 \\
\hline $\begin{array}{l}\text { Moment-resisting frames with } \\
\text { conventional }\end{array}$ & 1.05 & 1.18 & 1.05 & 1.00 & 1.00 & 1.30 & 1.3 \\
\hline \multicolumn{8}{|l|}{ construction } \\
\hline Ductile coupled walls & 1.05 & 1.18 & 1.05 & 1.25 & 1.05 & 1.71 & 1.7 \\
\hline Ductile partially coupled walls & 1.05 & 1.18 & 1.05 & 1.25 & 1.05 & 1.71 & 1.7 \\
\hline Ductile shear walls & 1.05 & 1.18 & 1.05 & 1.25 & 1.00 & 1.63 & 1.6 \\
\hline Moderately ductile shear walls & 1.05 & 1.18 & 1.05 & 1.10 & 1.00 & 1.43 & 1.4 \\
\hline $\begin{array}{l}\text { Shear walls with conventional } \\
\text { construction }\end{array}$ & 1.05 & 1.18 & 1.05 & 1.00 & 1.00 & 1.30 & 1.3 \\
\hline
\end{tabular}

\subsection{Comparison of International code provisions for reduction factors with the NBCC 2015}

\subsubsection{Response Reduction Factor as per Mexico City Building code (2004 Building Code)}

The Mexico City Building Code contains specific requirements to achieve either high or moderate ductility on the structural members and components for each structural material. A reduction factor Q' is used for the determination of the design base shear [10]. The assigned values of the force reduction factors are notably similar to the NBCC 2015 as illustrated in Table 6 . 
Table 6: Force modification factors per Mexico City Building Code (2004 Building Code). [10]

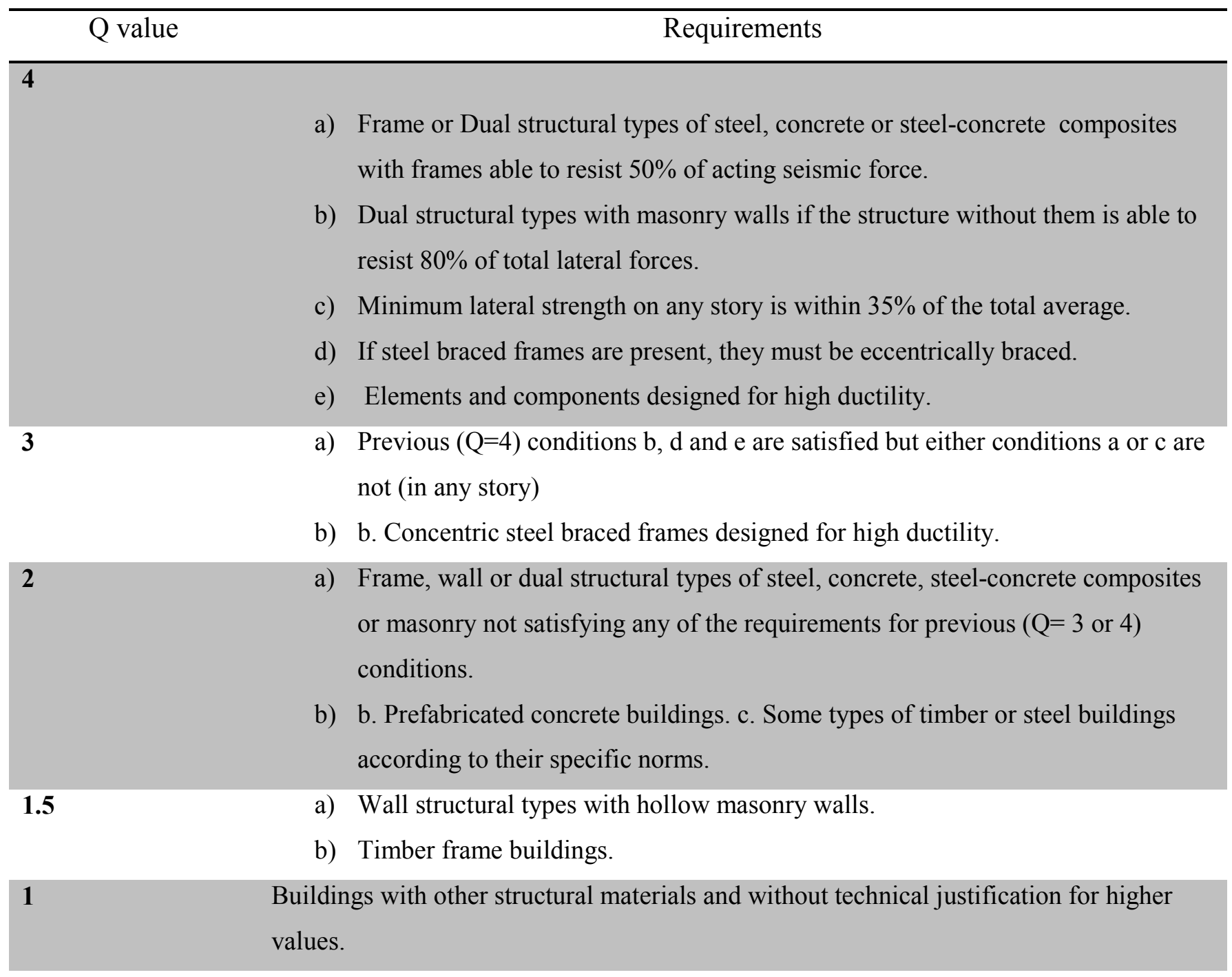

\subsubsection{Response Reduction Factor as per IBC/ASCE-07 Seismic}

The ASCE 7-10 incorporates a response modification coefficient $\mathrm{R}$ and an overstrength factor in the determination of the base shear. The classification of the SFRS in the ASCE 7-10 design code is more extensive than the NBCC 2015 with a larger number of classifications. Table 7 lists a few of the related SFRS force modification factors for comparison with the SFRS selected in this study. In broad terms, the modification factors per ASCE 7-10 code prescriptions appear less conservative than those stipulated by the NBCC code. For example, the maximum combined force reduction factor related to ductility and overstrength is $6.8(4 * 1.7)$ in comparison to 8 per ACSE 7-10 for special reinforced concrete moment frames. 
Table 7: Force modification factors per ASCE 7-10 Building Code (2004 Building Code). [11]

\begin{tabular}{llr}
\hline Seismic Force-Resisting System & $\begin{array}{l}\text { Response } \\
\text { Modification } \\
\text { Coefficient, } \mathbf{R}\end{array}$ & $\begin{array}{l}\text { Overstrength } \\
\text { Factor, } \boldsymbol{\Omega}\end{array}$ \\
\hline Special reinforced concrete shear walls & 5 & 2.5 \\
\hline Ordinary reinforced concrete shear walls & 4 & 2.5 \\
\hline Ordinary plain concrete shear walls & 1.5 & 3 \\
\hline Special reinforced concrete moment frames & 8 & 3 \\
\hline Ordinary reinforced concrete moment frames & 3 & 2.5 \\
\hline
\end{tabular}

\subsubsection{Response Reduction Factor as per Eurocode}

The Eurocode 8 (EC8) has three dissipation (ductility) classes, namely Low Ductility (DCL), Medium Ductility (DCM) and High Ductility (DCH) classes [14]. Table 8 below gives the ductility behavior factors for the two most commonly designed ductility class per EC8. It should be noted that Table 8 is a simplified version of the ductility class requirements as there are numerous other factors in consideration such as seismicity of the design site, measure of regularity of the structure, design material, etc.

Table 8: Basic behavior factor, $q_{\mathrm{o}}$, for systems in regular elevation per Eurocode 8 (EC8). [14]

\begin{tabular}{lll}
\hline Structural Type & DCM & DCH \\
\hline Frame system, dual system, coupled wall system & $3.0 \alpha_{\mathrm{u}} / \alpha_{1}$ & $4.5 \alpha_{\mathrm{u}} / \alpha_{1}$ \\
Uncoupled wall system & 3.0 & $4.0 \alpha_{\mathrm{u}} / \alpha_{1}$ \\
Torsionally flexible system & 2.0 & 3.0 \\
Inverted pendulum system & 1.5 & 2.0 \\
\hline
\end{tabular}

Where $\alpha_{u} / \alpha_{1}$ represents the ratio between the lateral load at which structural instability occurs and that at which the first yield occurs in any member. Default values of between 1.0 and 1.3 are given in the code with an upper limit of 1.5. 


\subsubsection{Response Reduction Factor in Japanese design code}

Per the Japanese Seismic Code (Building Standard law of Japan, 2004), [12], the base shear is computed using the following equation, where the coefficient Ds, represents the ductility response of the structural configuration. This value represents an inverted form of the NBCC 2015, ACSE 7-08 or most other international building codes.

(6) Vun,i = Ds,i Fes, i Vi.

Table 9: $\mathrm{D}_{\mathrm{s}}$ values for reinforced concrete structures (for steel reinforced concrete structures, subtract 0.05 from the tabulated value of $\mathrm{D}_{\mathrm{s}}$ ) [12]

STRUCTURAL TYPE

\begin{tabular}{|c|c|c|c|}
\hline Framing Members & $\begin{array}{l}\text { (a) Rigid frames or } \\
\text { very ductile shear wall } \\
\text { with } \beta_{w} \leq 0.5\end{array}$ & $\begin{array}{l}\text { (b) Very ductile or } \\
\text { ductile shear wall with } \\
\beta_{w} \leq 0.7\end{array}$ & $\begin{array}{l}\text { (c) Very ductile or } \\
\text { ductile shear wall with } \\
\boldsymbol{\beta}_{w} \leq 0.7 \text {, or less } \\
\text { ductile shear wall }\end{array}$ \\
\hline Most Ductile & 0.25 & 0.30 & 0.35 \\
\hline Very Ductile & 0.30 & 0.35 & 0.40 \\
\hline Ductile & 0.35 & 0.40 & 0.45 \\
\hline Others & 0.40 & 0.45 & 0.50 \\
\hline
\end{tabular}

$\beta_{w}=$ ratio of load carried by shear walls to total story shear. The classification of very ductile, ductile, or less ductile shear walls depends mainly on the shear stress level at ultimate and on the mode of failure. 


\section{Chapter 4 Analysis and interpretation of results}

The tabulated results obtained from both the Response Spectrum Analysis (RSA) and the Equivalent Lateral Force Procedure (ELFP) is provided in Appendix B and Appendix E.

\subsection{Lateral Period of the Structure}

The modal parameters were combined using the complete quadratic combination (CQC) method. The computed periods and the modal response characteristic of the test models are presented in Table 10 and Table 11. The number of modes selected was based on the minimum requirement of the accumulated modal mass should equal or exceed $90 \%$ of the total mass.

Table 10: Fundamental lateral period, Ta used for design

\begin{tabular}{llllll}
\hline & & Ta, code $(\mathbf{s})$ & Ta, etabs $(\mathbf{s})$ & Ta, design $(\mathbf{s})$ & H (m) \\
\hline Shear Wall & Model 1 & 0.87 & 1.217 & 1.217 & 45 \\
& Model 2 & 2.11 & 8.826 & 4.22 & 174.2 \\
Model 3 & 0.87 & 1.217 & 1.217 & 45 \\
Moment Frame & Model 4 & 2.11 & 8.826 & 4.22 & 147.02 \\
& Model 5 & 1.30 & 1.854 & 1.854 & 45 \\
& Model 6 & 3.17 & 7.382 & 4.755 & 147.2 \\
& Model 7 & 1.30 & 1.854 & 1.854 & 45 \\
& Model 8 & 3.17 & 7.382 & 4.755 & 147.2 \\
\hline
\end{tabular}

Table 11: Periods and Modal Response Characteristics from Dynamic Analysis

\begin{tabular}{llll}
\hline Model & Period (s) & \multicolumn{1}{c}{$\begin{array}{c}\text { \% of Effective Mass } \\
\text { Represented by Mode* }\end{array}$} & Description \\
\cline { 3 - 4 } & & X-dir (E-W) & \\
$\mathbf{1}$ & 91.3 & Translation in the x-direction \\
$\mathbf{3}$ & 1.217 & 92.4 & Translation in the x-direction \\
$\mathbf{4}$ & 8.826 & 91.3 & Translation in the x-direction \\
$\mathbf{5}$ & 1.217 & 92.4 & Translation in the x-direction \\
$\mathbf{6}$ & 8.826 & 91.9 & Translation in the x-direction \\
$\mathbf{7}$ & 1.854 & 93.4 & Translation in the x-direction \\
$\mathbf{8}$ & 7.382 & 91.9 & Translation in the x-direction \\
\hline
\end{tabular}




\subsection{Seismic Base Shear}

In accordance with NBCC $2015 \mathrm{Cl}$.4.1.8.12 (8), if the design base shear, $\mathrm{V}_{\mathrm{d}}$ obtained from linear dynamic analysis is less than $80 \%$ of the lateral earthquake design force $\mathrm{V}$, obtained from the Equivalent Lateral Force Procedure ( $\mathrm{Cl}$. 4.1.8.11), then $\mathrm{V}_{\mathrm{d}}$ shall be taken as $0.8 \mathrm{~V}$. Based on the results obtained from both the Response Spectrum Analysis (RSA) and the Equivalent Lateral Force Procedure (ELFP), the effect of the ductility and overstrength factors of the structure is notable. Based on the results as shown in Table 11 and Table 13, the following results are highlighted:

1. For shear wall configurations, using RSA, the base shear of both the 12 and 40 story buildings are similar for both the ductile and conventional construction. For e.g. the $\mathrm{V}_{\mathrm{RSA}, 12 \text { storey }}=3749$ $\mathrm{kN}$ and $\mathrm{V}_{\mathrm{RSA}, 40 \text { storey }}=3350 \mathrm{kN}$. While this result is unexpected, the significantly larger period for the 40 story structure, as well as the high ductility (flexibility) of both structures might account for these results. The higher the natural period of a structure is an indicator of higher flexibility. Also, the high ductility of the structure means that it is less stiff and therefore considering $\mathrm{F}=\mathrm{kU}$, with ductile structures having smaller $\mathrm{k}$ values, the base shear tends to be smaller as well since generally flexible structures experiences lower accelerations than a stiffer buildings.

2. For the 12 story buildings, the seismic base shear obtained through both the RSA and ELFP are within $20 \%$ or less discrepancy with the RSA results lower for both the ductile and conventional shear wall buildings. This result is also similar for the moment frame buildings as well. These results justify the NBCC code upper limit of $60 \mathrm{~m}$ in building height above base that can be designed using the static ELFP procedure. The results obtained from the ELFP for the taller structure, $(147.2 \mathrm{~m})$ is overly conservative. It is observed that for the 40 story buildings, the seismic base shear obtained through the RSA and ELFP are markedly different. For e.g., $\mathrm{V}_{\mathrm{RSA}, 40 \text { storey }}=3350 \mathrm{kN}$ and $\mathrm{V}_{\mathrm{ELFP}, 40 \text { storey }}=6342 \mathrm{Kn}$ indicating a difference of almost $50 \%$. Again, this is an indication that the effect of the ductility of the building is magnified as building height increases due to the increase in the natural period. The results for the moment frame 40 storey buildings follow a similar pattern as well. 
Table 12: Design Base Shear Comparison - Shear Wall (SFRS)

\section{Design Base Shear Comparison - Shear Wall (SFRS) X-dir (E-W)}

\begin{tabular}{lllll}
\hline Model & RSA, V $(\mathrm{kN})$ & ELFP, V $(\mathrm{kN})$ & $\%$ RSA/ELFP & $\mathrm{V}_{\mathrm{d}}(\mathrm{Selected})(\mathrm{kN})$ \\
1 (L_SW_D) & 3749 & 4452 & $84.21 \%$ & 3749 \\
$\mathbf{2}$ (H_SW_D) & 3350 & 6342 & $52.82 \%$ & 5074 \\
3 (L_SW_C) & 10775 & 12993 & $82.93 \%$ & 10775 \\
$\mathbf{4}$ (H_SW_C) & 11968 & 18213 & $65.71 \%$ & 14570 \\
\hline
\end{tabular}

Table 13: Design Base Shear Comparison - Moment Frame (SFRS)

\begin{tabular}{|c|c|c|c|c|}
\hline \multicolumn{5}{|c|}{ Design Base Shear Comparison - Shear Wall (SFRS) } \\
\hline Model & $\mathrm{RSA}, \mathrm{V}_{\mathrm{d}}(\mathrm{kN})$ & ELFP, V (kN) & $\%$ RSA/ELFP & $\mathrm{V}_{\mathrm{d}}($ Selected $)(\mathrm{kN})$ \\
\hline 5 (L_MF_D) & 1909 & 2489 & $76.70 \%$ & 1991 \\
\hline 6 (H_MF_D) & 3185 & 7336 & $43.42 \%$ & 5869 \\
\hline 7 (L_MF_C) & 6667 & 8680 & $76.81 \%$ & 6944 \\
\hline 8 (H_MF_C) & 11126 & 25581 & $43.49 \%$ & 20465 \\
\hline
\end{tabular}

\subsection{Distribution of Lateral Force}

The story forces are distributed to the various vertical elements of the seismic force-resisting system based on relative rigidity using the ETABS model. The buildings are modeled using rigid diaphragms at each floor. Since the structures are symmetric in both directions and the distribution of mass is assumed to be uniform, there is no inherent torsion at either building. However, accidental torsion should be considered in accordance with $\mathrm{Cl}$. 4.1.8.11 (11). However for the scope of this study, accidental torsion results will not be analyzed. Based on the results shown in Figure 11 to Figure 22 the following are notable observations:

1. The lateral force distribution of shear walls and moment frames were similar, with the lateral loads distributed between the two systems according to their relative stiffness. However, in general, the two systems deform with their own characteristic shapes. The interaction between the two, particularly at the upper levels of the buildings, results in quite a different lateral load distribution.

2. The results obtained from the response spectrum analysis appear to be scaled linearly by the ratio of the RdRo factors of the SFSR configuration. For e.g, the Low-Rise Ductile Shear Wall 
building has a base shear of $3749 \mathrm{kN}$ while Low-Rise Conventional Shear Wall building has a base shear of $10775 \mathrm{kN}$. The ratio of base shear of the respective SFRS is approximately equal to the ratio of the RdRo factors. This result is consistent with all 8 models.

3. The shear wall and frame appear to display constant stiffness throughout the height of the structure based on the similar design of each floor.

4. The slope of the shear wall curves appear to be more steep that the moment frame curves as is expected as the shear wall acts as vertical cantilever column with a greater slope at the top.

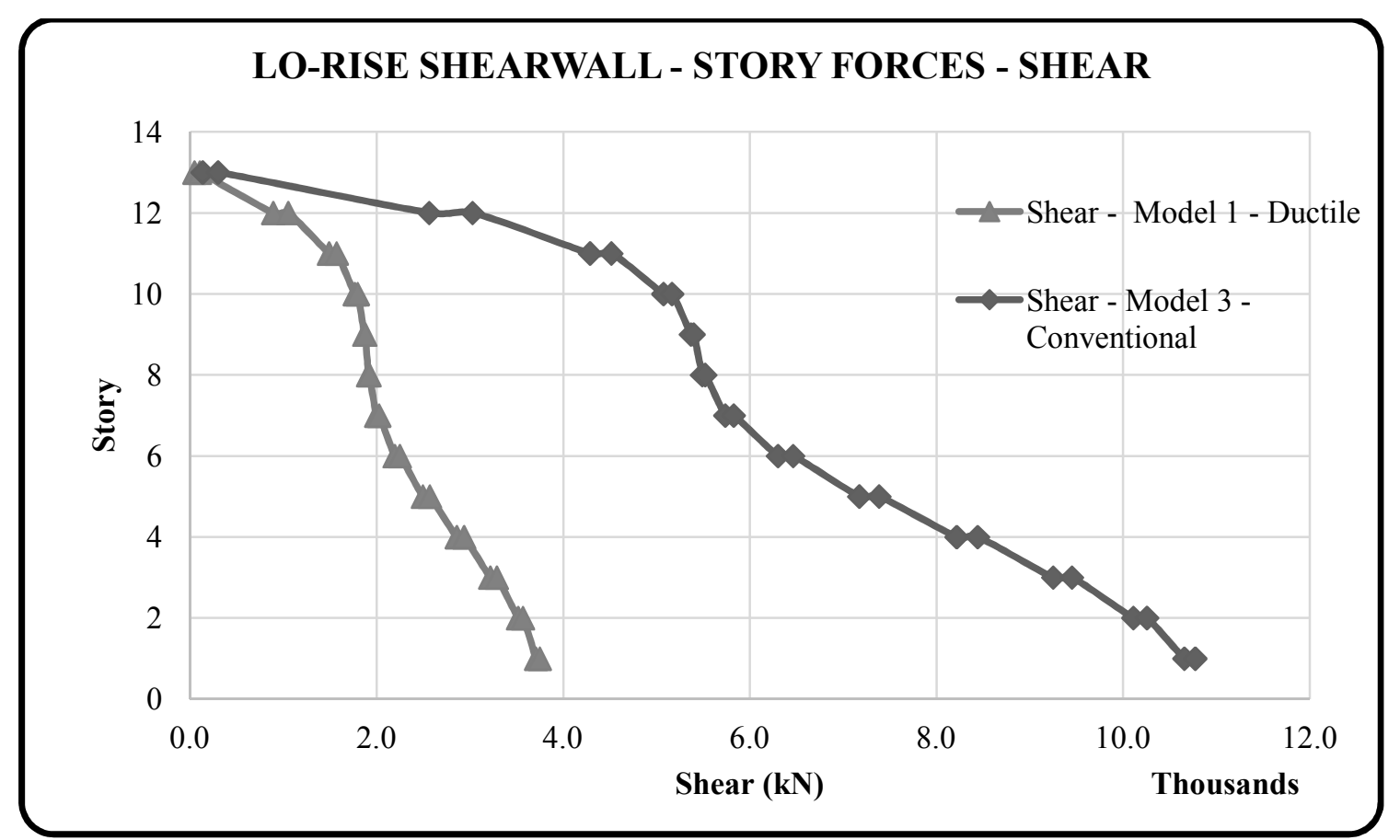

Figure 11: Low Rise Shear Wall SFRS: Lateral Force Distribution - SHEAR 


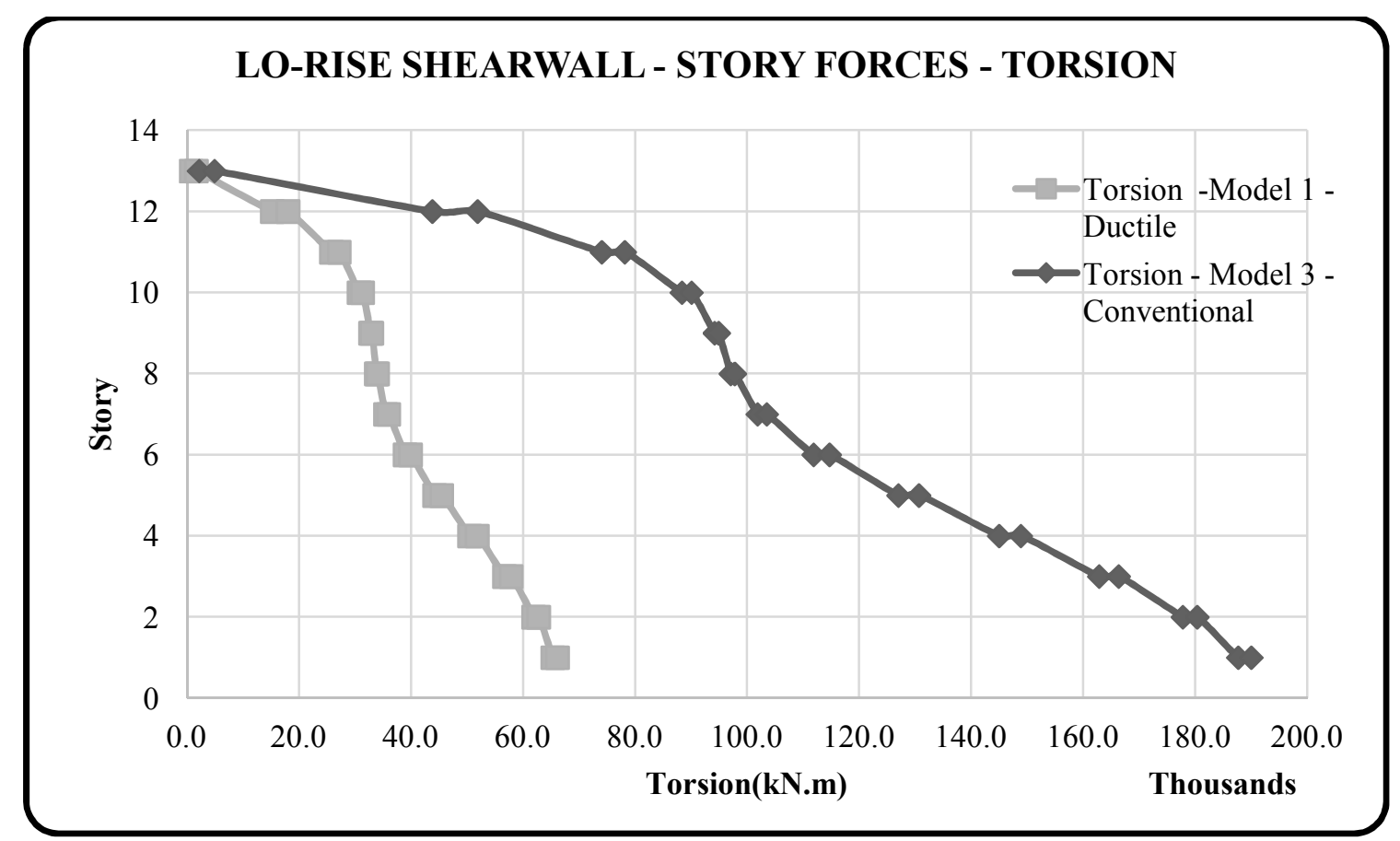

Figure 12: Low Rise Shear Wall SFRS: Lateral Force Distribution - TORSION

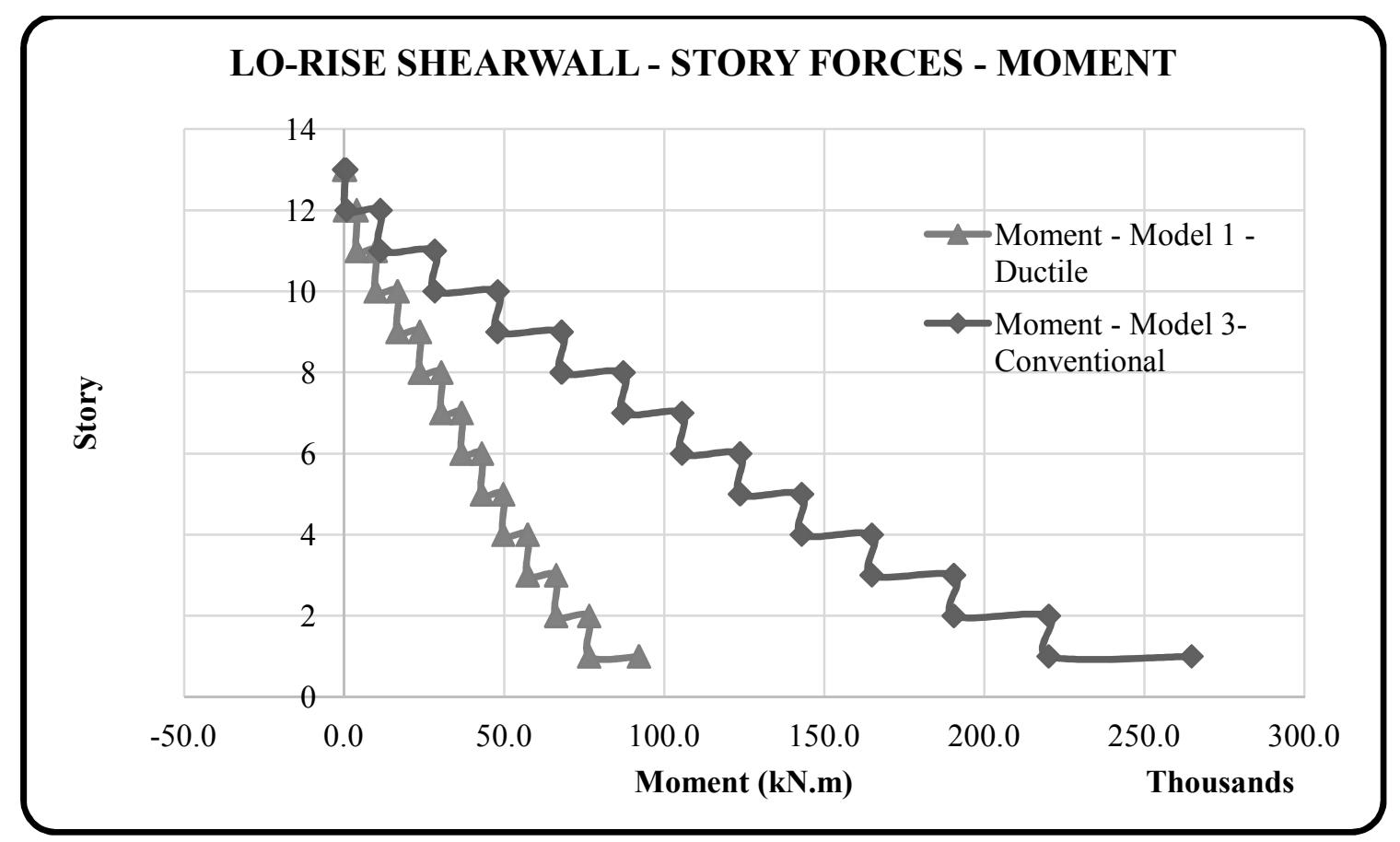

Figure 13: Low Rise Shear Wall SFRS: Lateral Force Distribution - MOMENT 


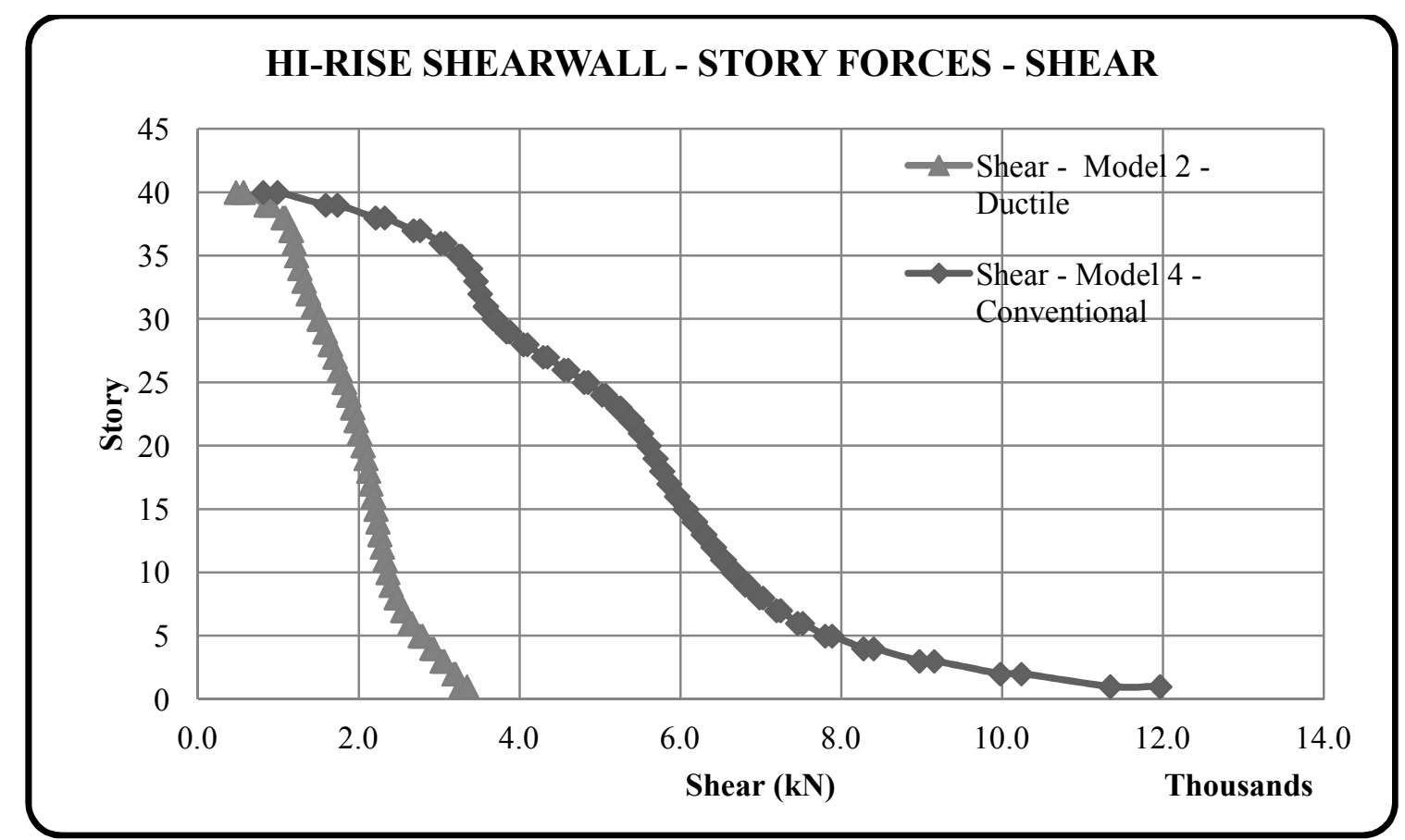

Figure 14: High Rise Shear Wall SFRS: Lateral Force Distribution - SHEAR

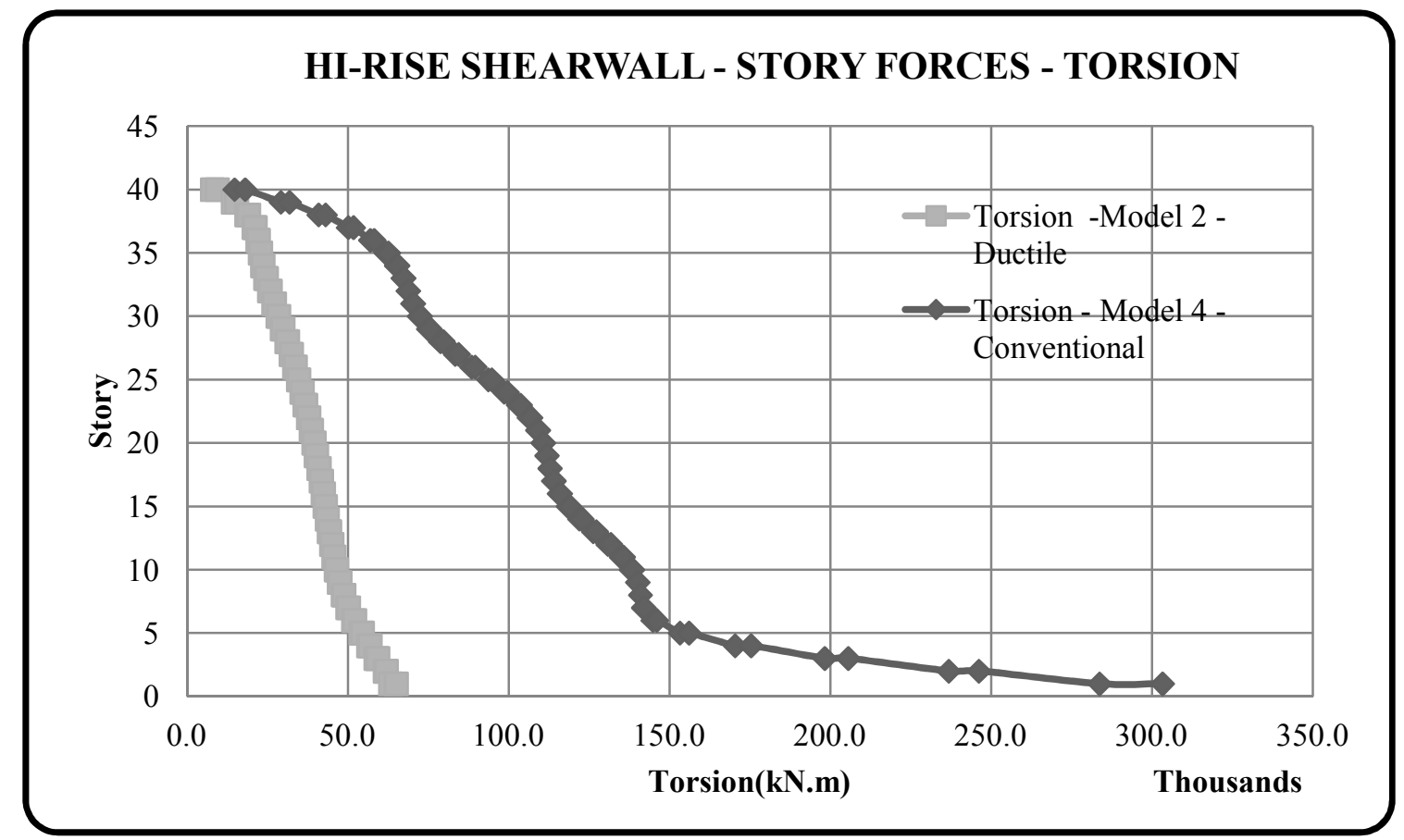

Figure 15: High Rise Shear Wall SFRS: Lateral Force Distribution - TORSION 


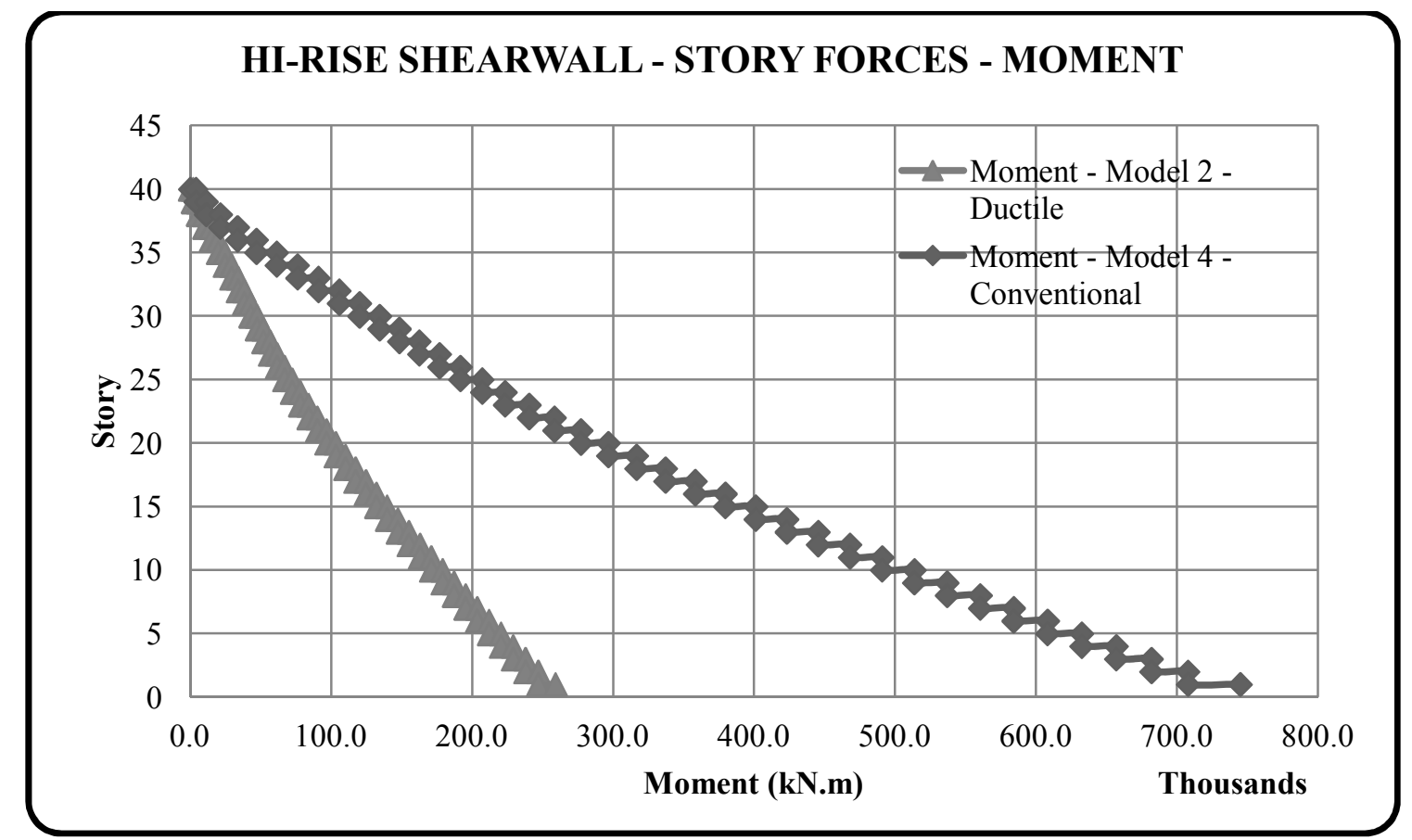

Figure 16: High Rise Shear Wall SFRS: Lateral Force Distribution - MOMENT

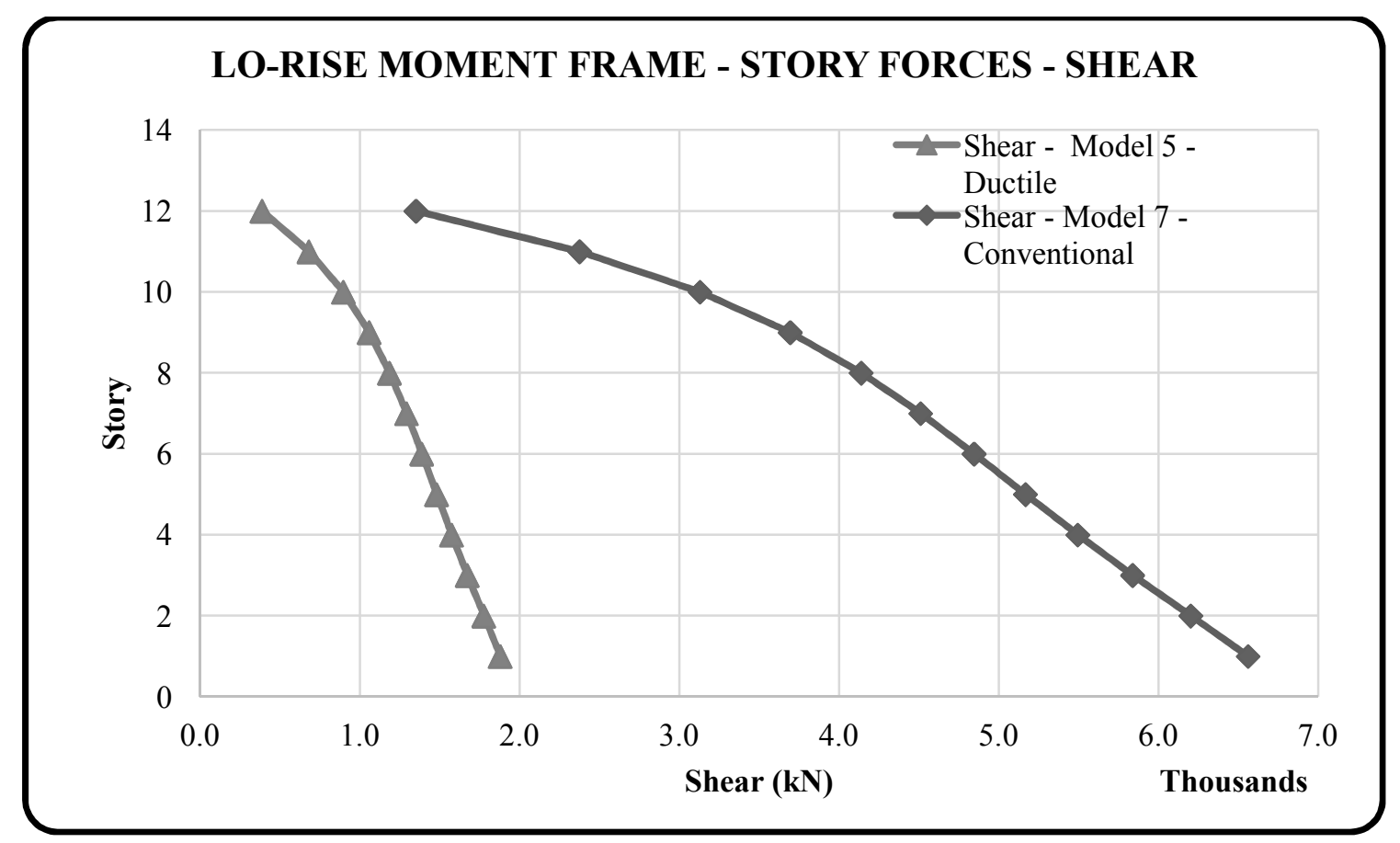

Figure 17: Low Rise Moment Frame SFRS: Lateral Force Distribution - SHEAR 


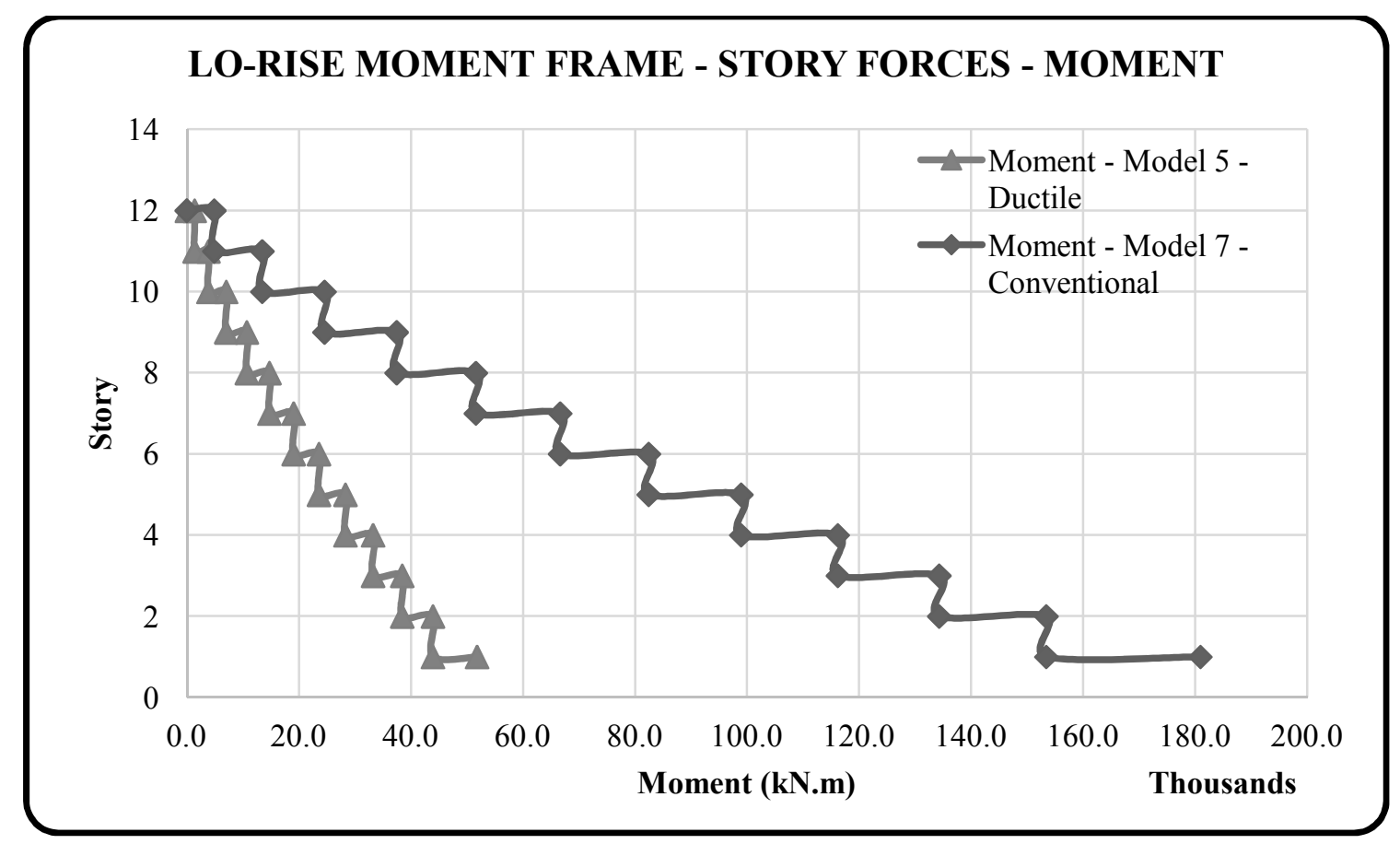

Figure 18: Low Rise Moment Frame SFRS: Lateral Force Distribution - MOMENT

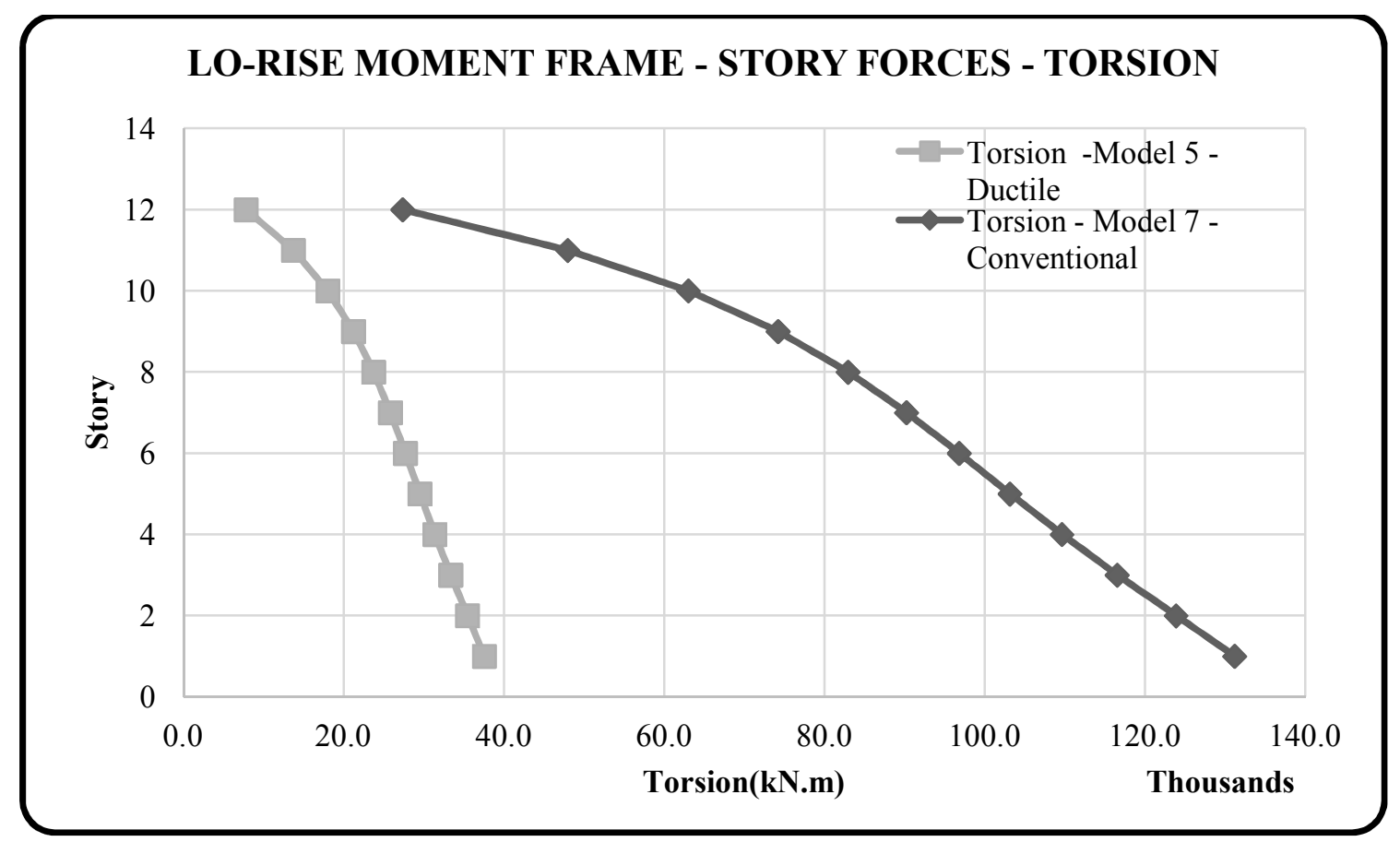

Figure 19: Low Rise Moment Frame SFRS: Lateral Force Distribution - TORSION 


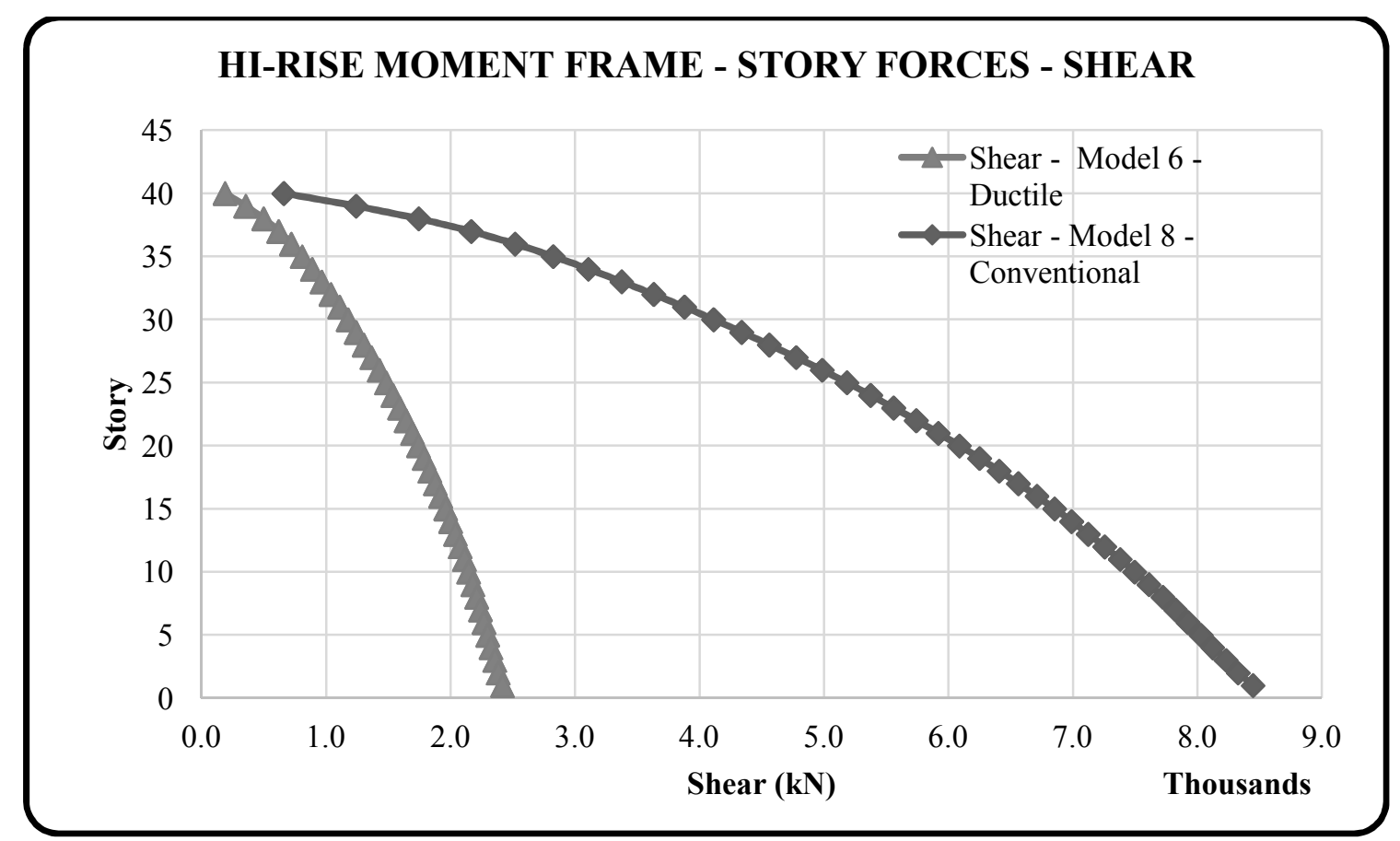

Figure 20: High Rise Moment Frame SFRS: Lateral Force Distribution - SHEAR

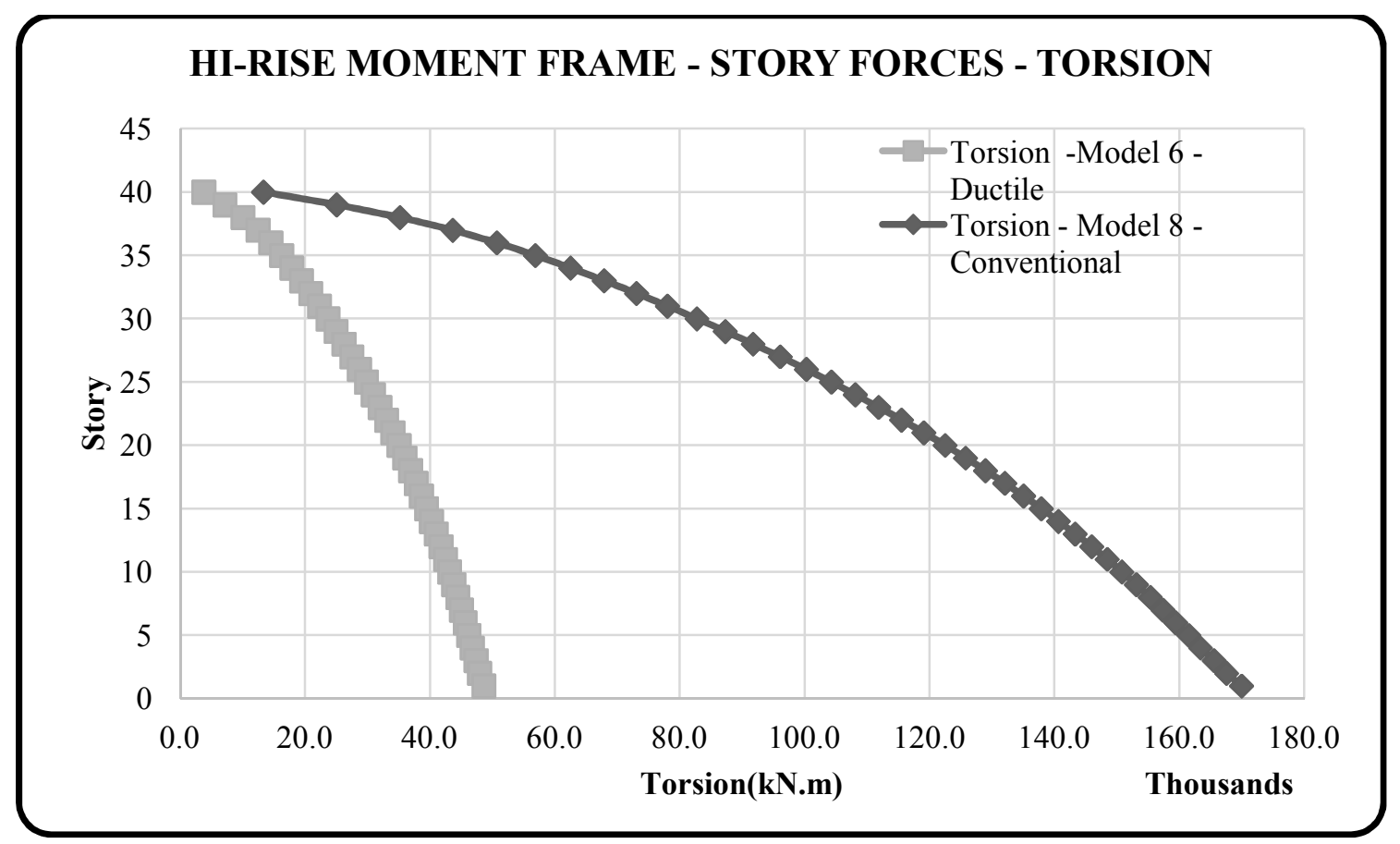

Figure 21: High Rise Moment Frame SFRS: Lateral Force Distribution - TORSION 


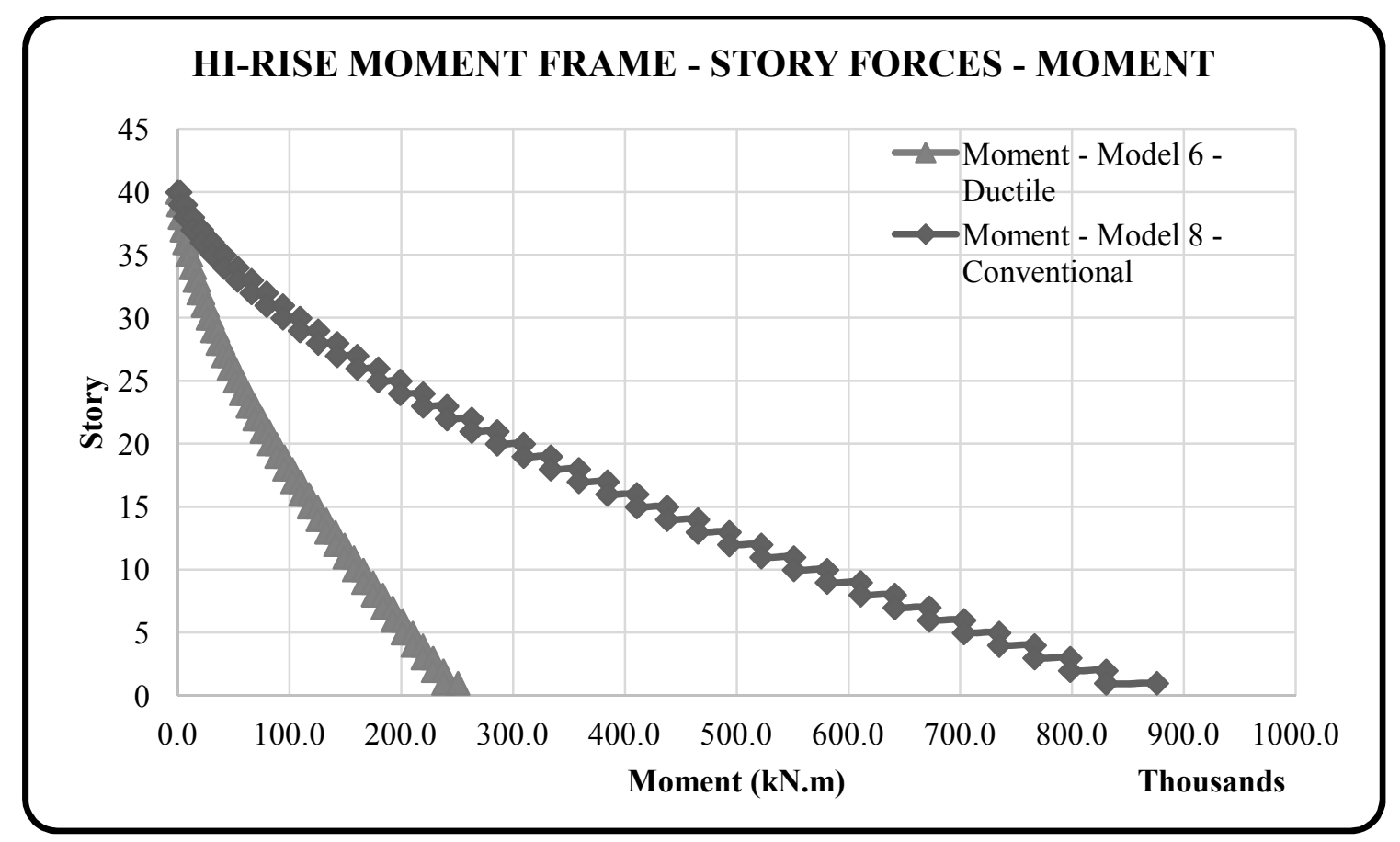

Figure 22: High Rise Moment Frame SFRS: Lateral Force Distribution - MOMENT 


\subsection{Drift Checks and Drift profile}

The limit on deflections and interstorey drifts limits are in accordance with Cl. 4.1.8.13, where the lateral deflections obtained from linear elastic analysis shall be multiplied by $\mathrm{RdRo} / \mathrm{I}_{\mathrm{E}}$ to give realistic values of anticipated deflections. Per NBCC 2015 provisions, an upper limit of $0.025 \mathrm{~h}_{\mathrm{s}}$ was imposed as the acceptable interstorey drift criteria check. The interstorey drift limit for the first floor is $0.12125 \mathrm{~m}$ and for all other floors is $0.09125 \mathrm{~m}$. Based on the results shown in Figure 23 to Figure 26, the following are notable observations:

1. As stated previously, the deflection modes of shear walls and moment frames were similar because the lateral loads would be distributed between the two systems more or less, according to their relative stiffness. However, in general, the two systems deform with their own characteristic shapes. The interaction between the two, particularly at the upper levels of the buildings, results in quite a different lateral load distribution.

2. The lateral deflections of the shear wall deflect similar to those of a cantilever column where near the bottom, the shear wall is relatively stiff, and therefore, the floor-to-floor deflections are less than half the values near the top. At top floors, the deflections increase rather rapidly, mainly from the cumulative effect of wall rotation.

3. Moment frames, on the other hand, deform predominantly in a shear mode. The relative story deflections depend primarily on the magnitude of shear applied at each story level. Although the deflections are larger near the bottom and smaller near the top as compared to the shear walls, the floor-to-floor deflections can be considered more nearly uniform throughout the height.

4. The results obtained from the response spectrum analysis appear to be scaled linearly by the ratio of the RdRo factors of the SFSR configuration.

5. The interstorey drifts for all 8 models were with code accepted limts. 


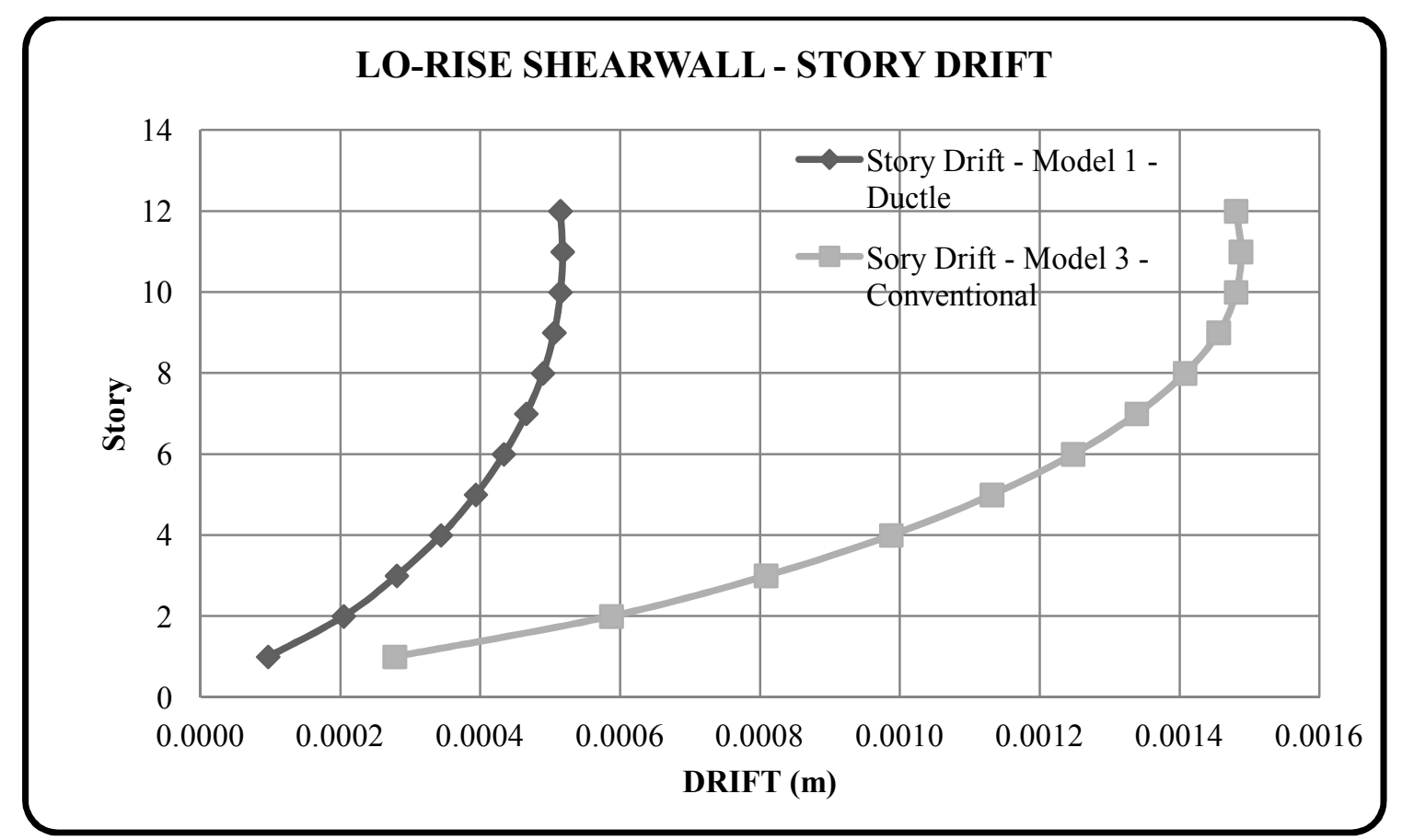

Figure 23: Low Rise Shear Wall SFRS: STORY DRIFT

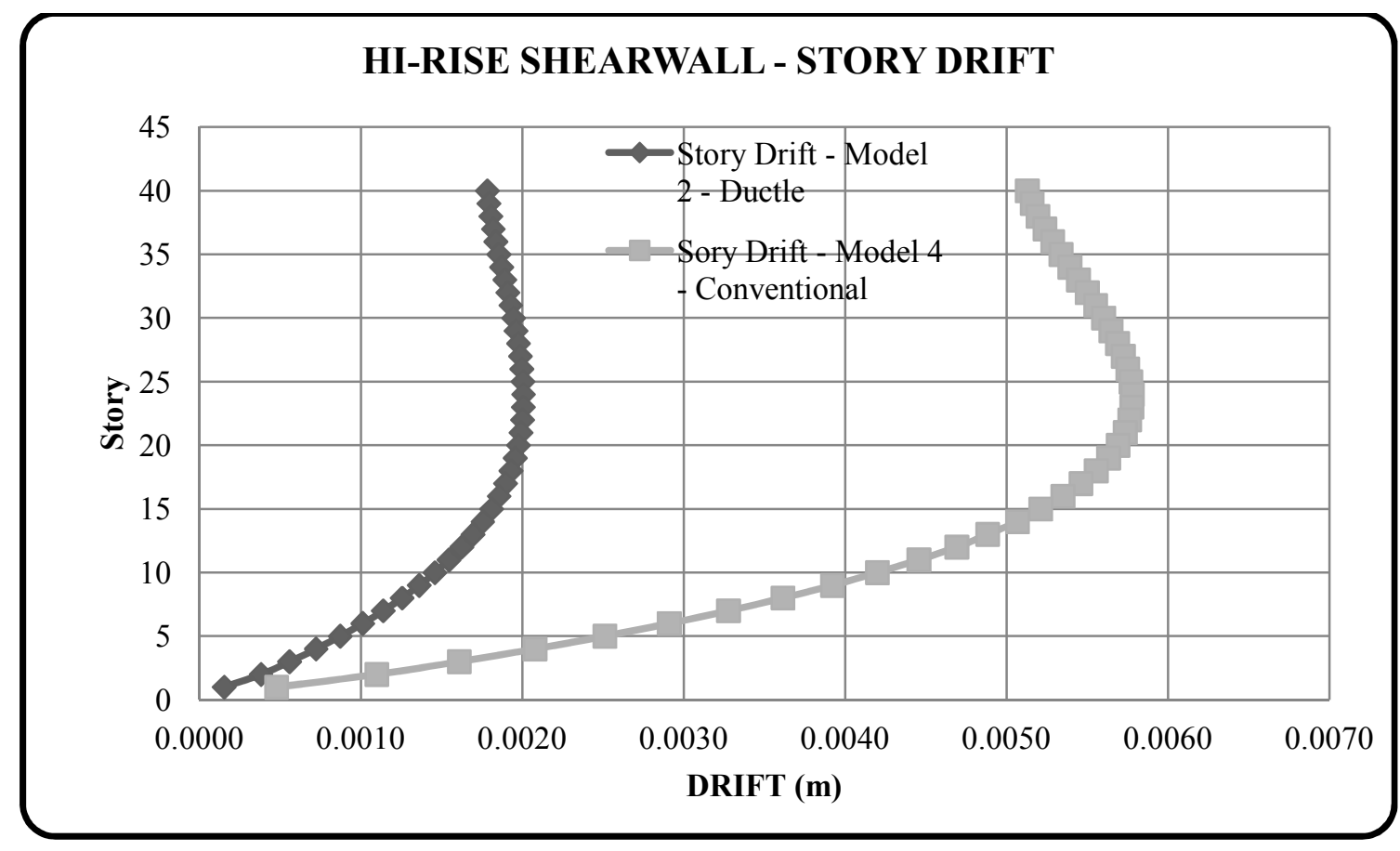

Figure 24: High Rise Shear Wall SFRS: STORY DRIFT 


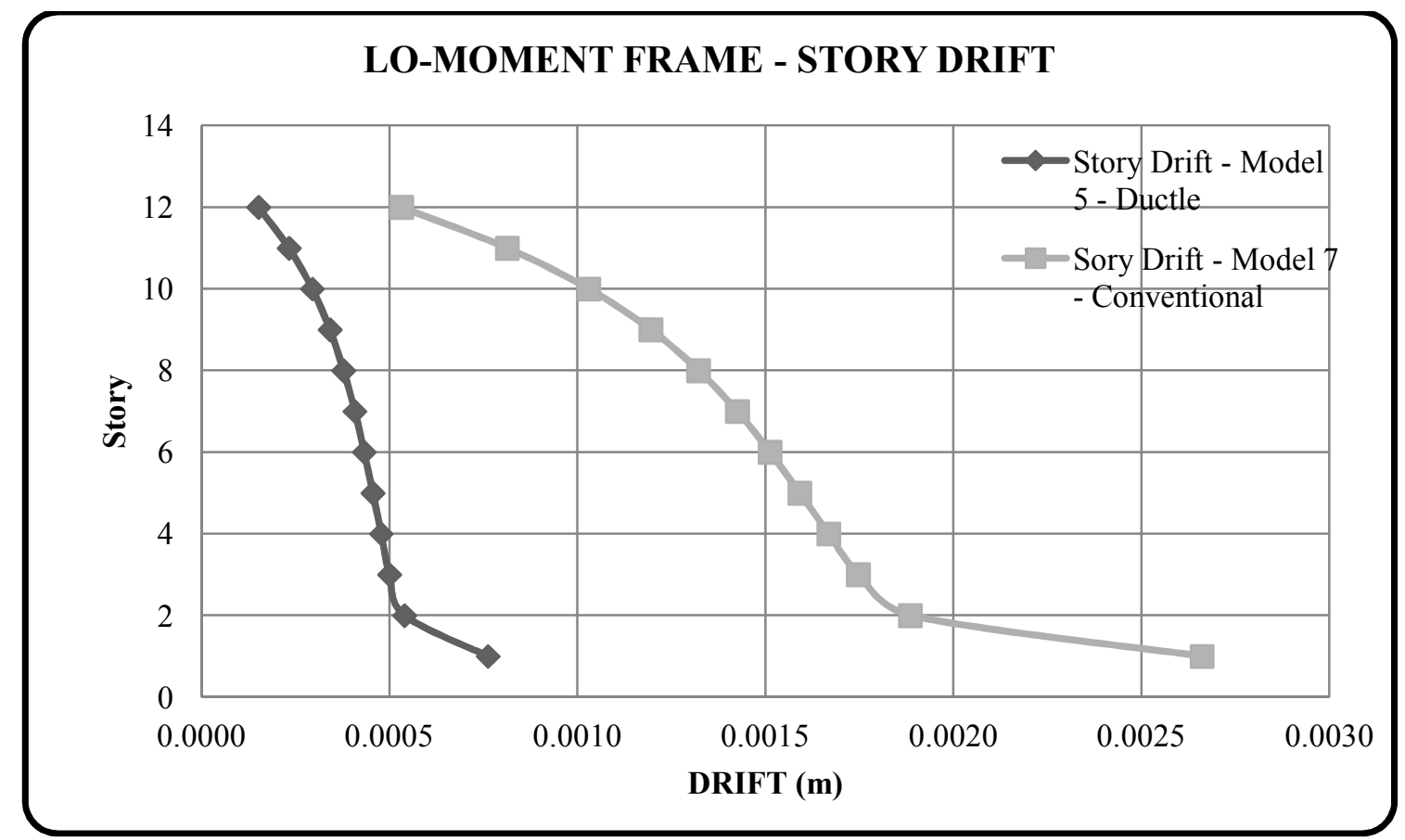

Figure 25: Low Rise Moment Frame SFRS: STORY DRIFT

\section{HI-MOMENT FRAME - STORY DRIFT}

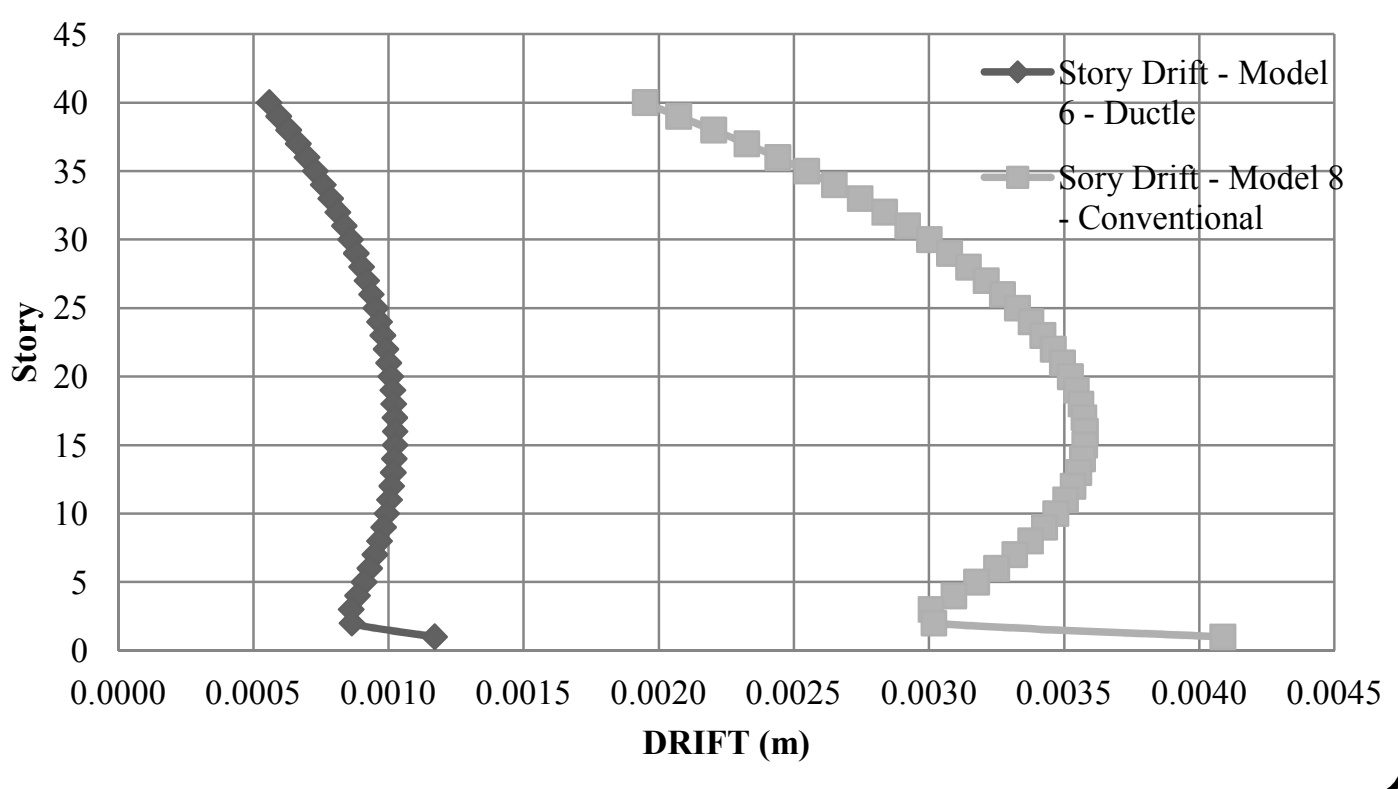

Figure 26: High Rise Moment Frame SFRS: STORY DRIFT 


\subsection{Member Forces: Shear Wall}

The exterior wall at the S-E corner of the building was selected to provide sample results. Based on the results shown in Figure 27 to Figure 34Figure 26, the following are notable observations:

1. As expected, the slope of the conventional construction curves is significantly steeper than the ductile curves. The wall forces distributed throughout the height of the building is much more uniform for the ductile configuration hence the member sizes and capacity demand is more uniform for the ductile configuration as opposed to conventional construction. This means that similar wall and slab thickness would be required on the lower floors for a ductile configuration as opposed to a conventional construction that would require significantly larger members on the lower floors in order to meet the capacity demand requirements.

2. The conventional construction configurations, especially in the taller buildings appear to be sensitive to torsional effects at the lower floors when exposed to dynamic earthquake force. This is likely a contributing factor for the $20 \mathrm{~m}$ and $40 \mathrm{~m}$ height limitation in regions of mid to high seismicity, $\leq 0.35\left(\mathrm{I}_{\mathrm{E}} \mathrm{FaSa}(0.2)\right) \leq 0.75$ for moment resisting frames and shear wall respectively.

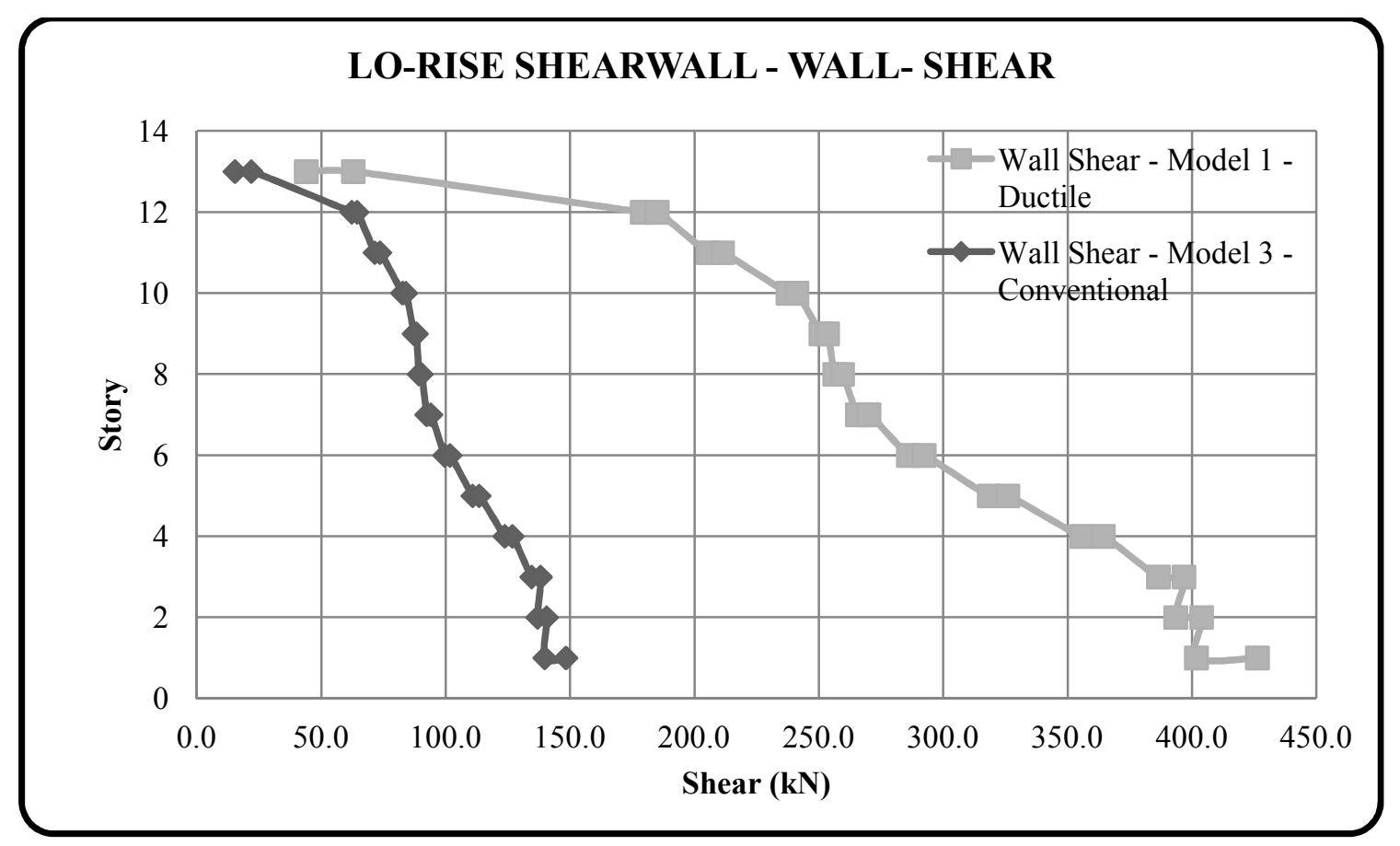

Figure 27: Low Rise Shear Wall SFRS: WALL SHEAR 


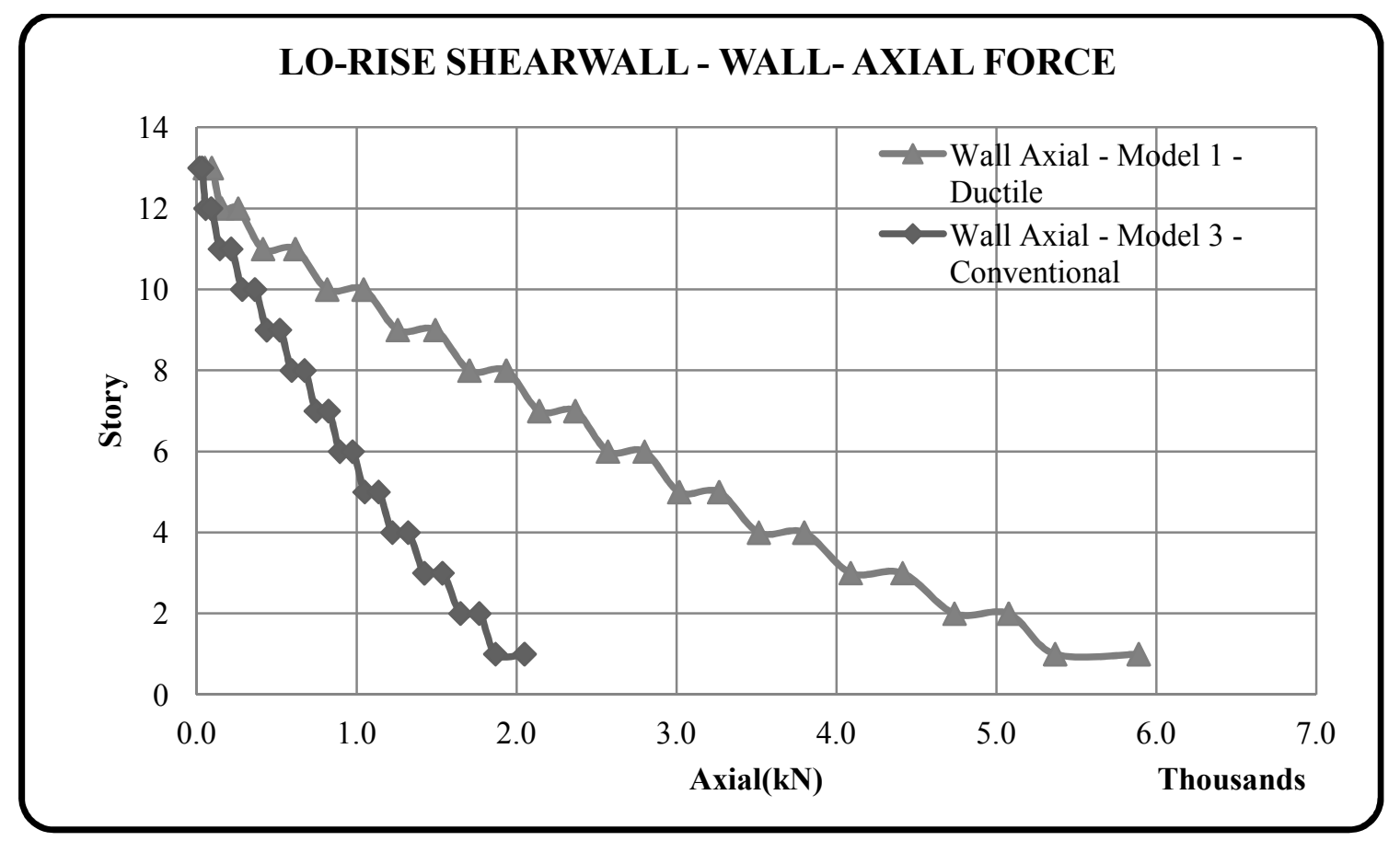

Figure 28: Low Rise Shear Wall SFRS: WALL AXIAL FORCE

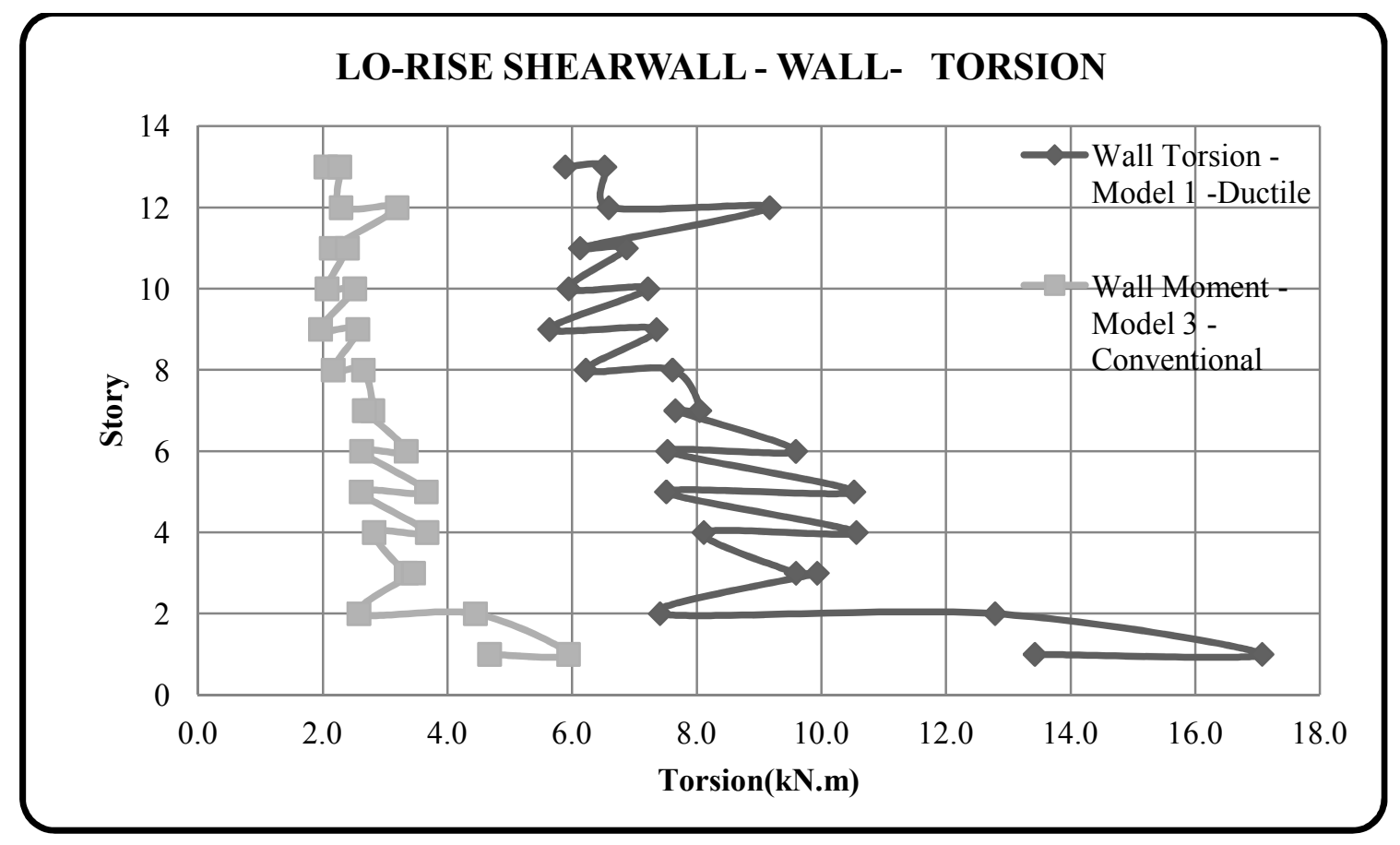

Figure 29: Low Rise Shear Wall SFRS: WALL TORSION 


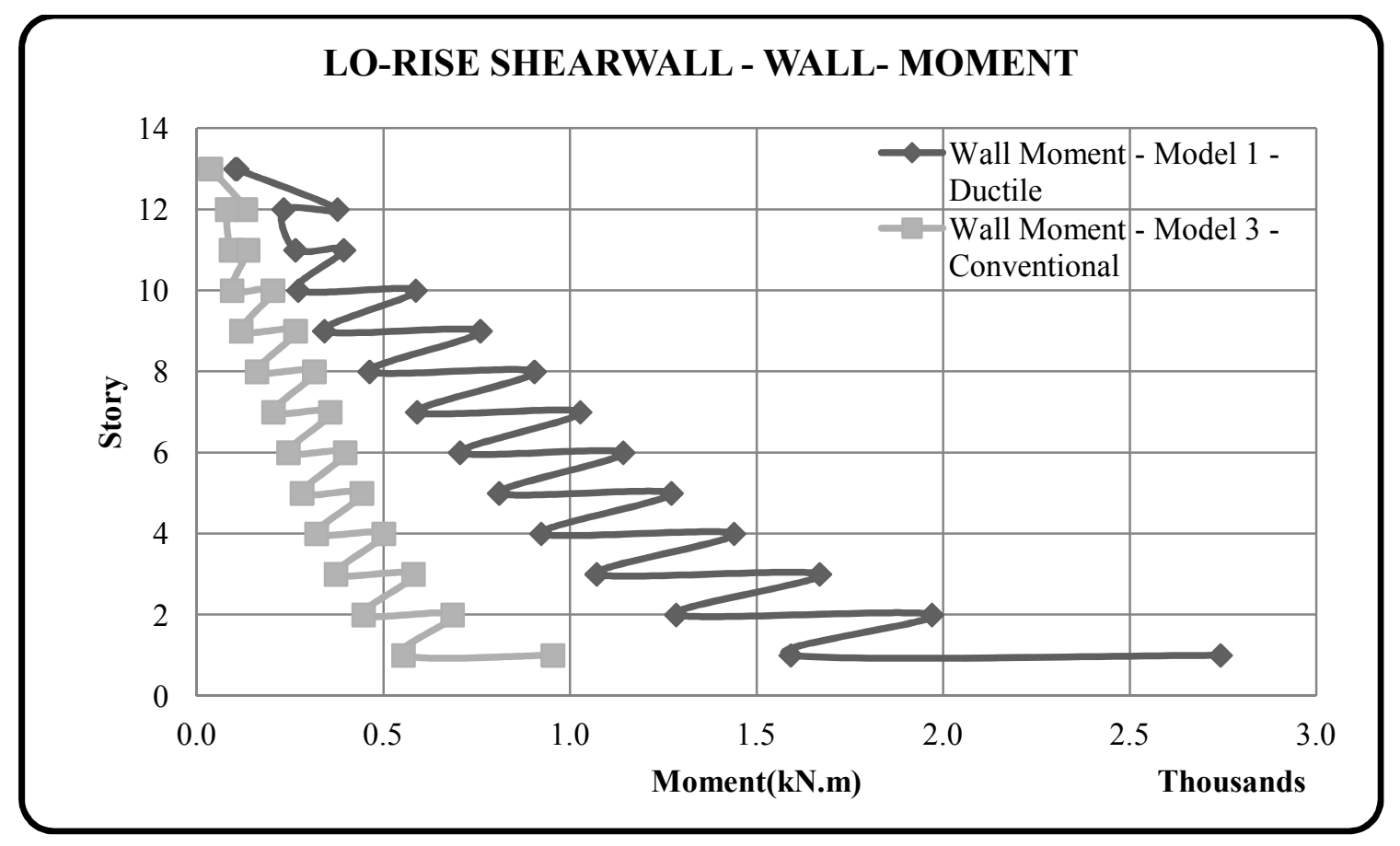

Figure 30: Low Rise Shear Wall SFRS: WALL MOMENT

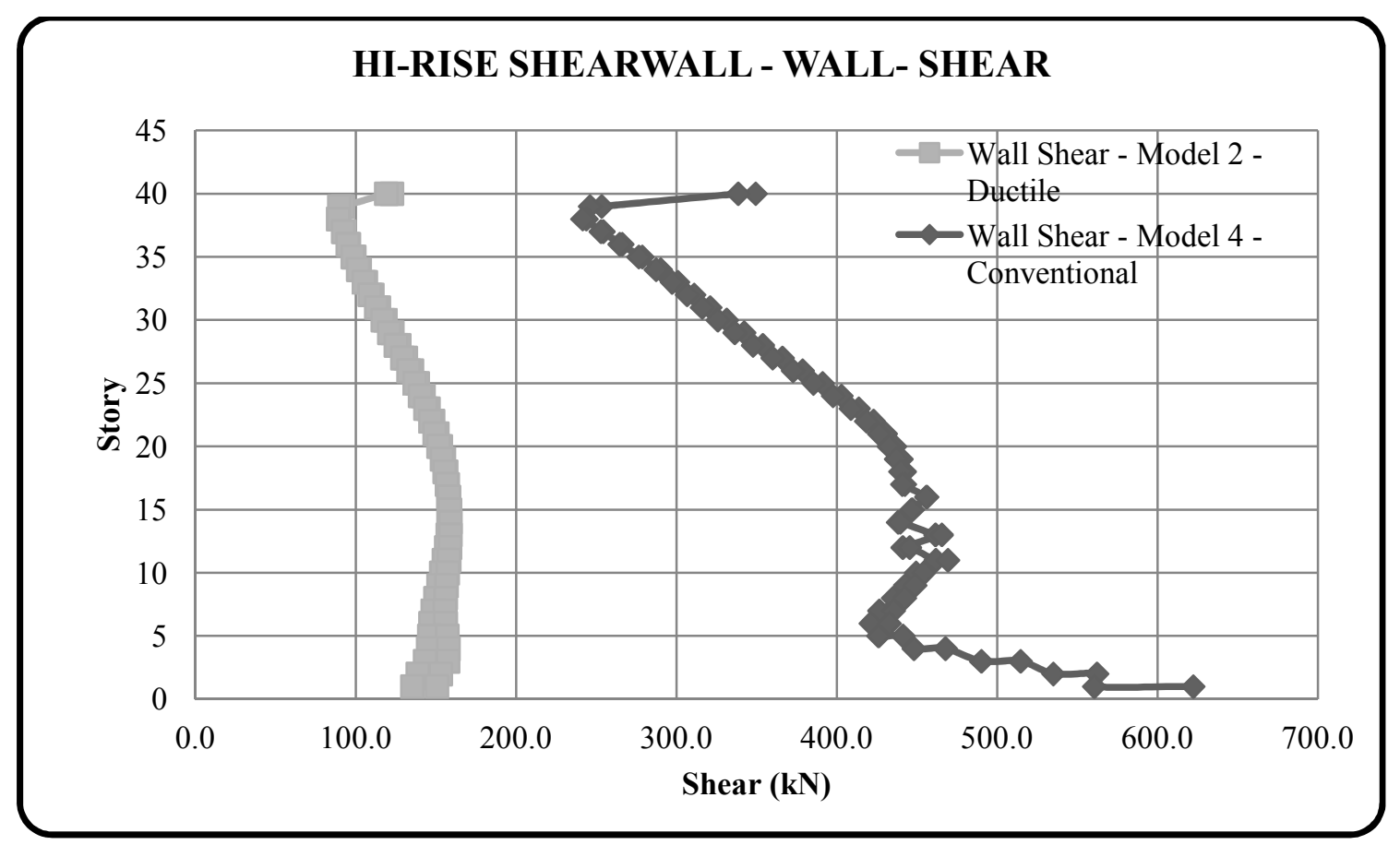

Figure 31: High Rise Shear Wall SFRS: WALL SHEAR 


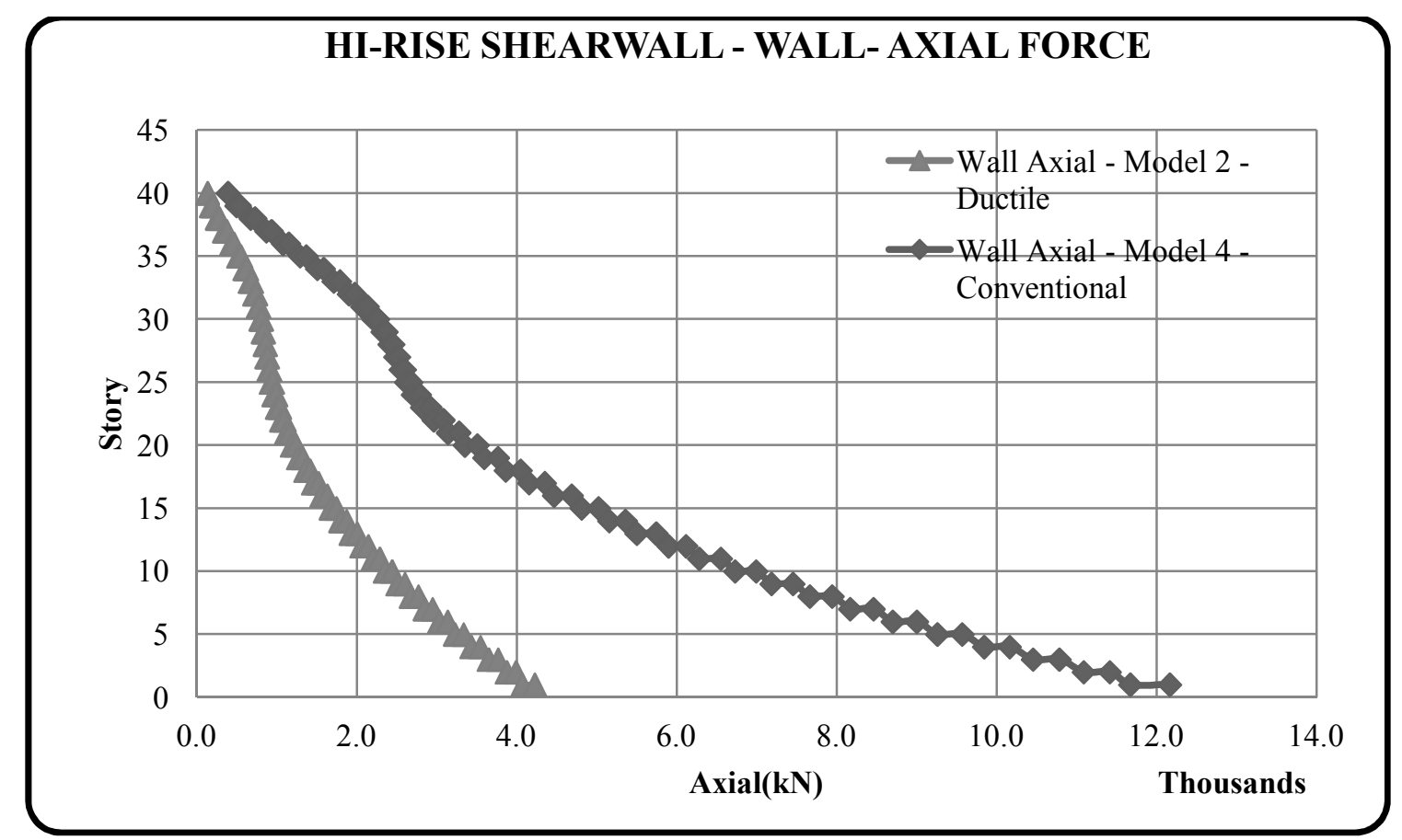

Figure 32: High Rise Shear Wall SFRS: WALL AXIAL FORCE

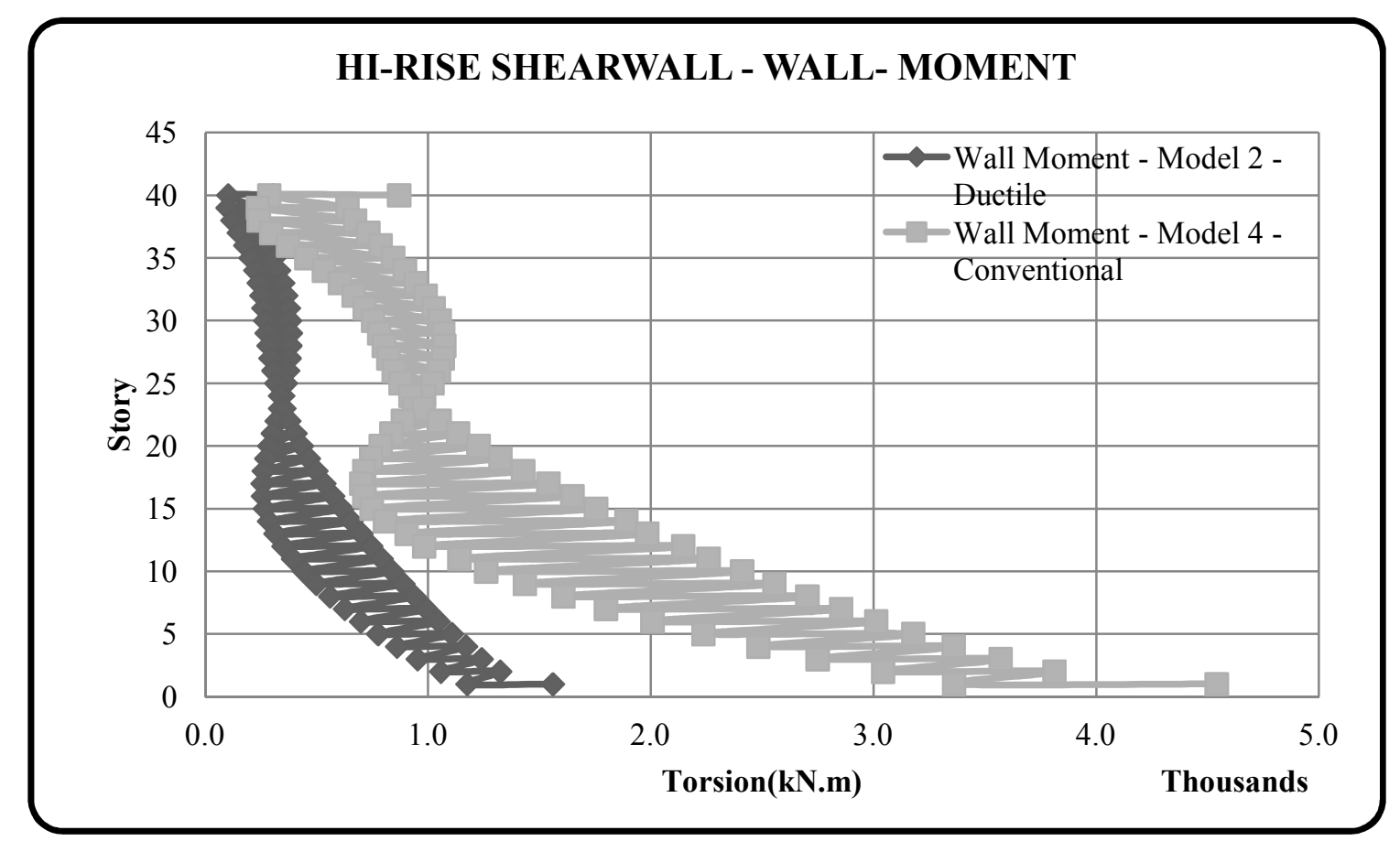

Figure 33: High Rise Shear Wall SFRS: WALL MOMENT 


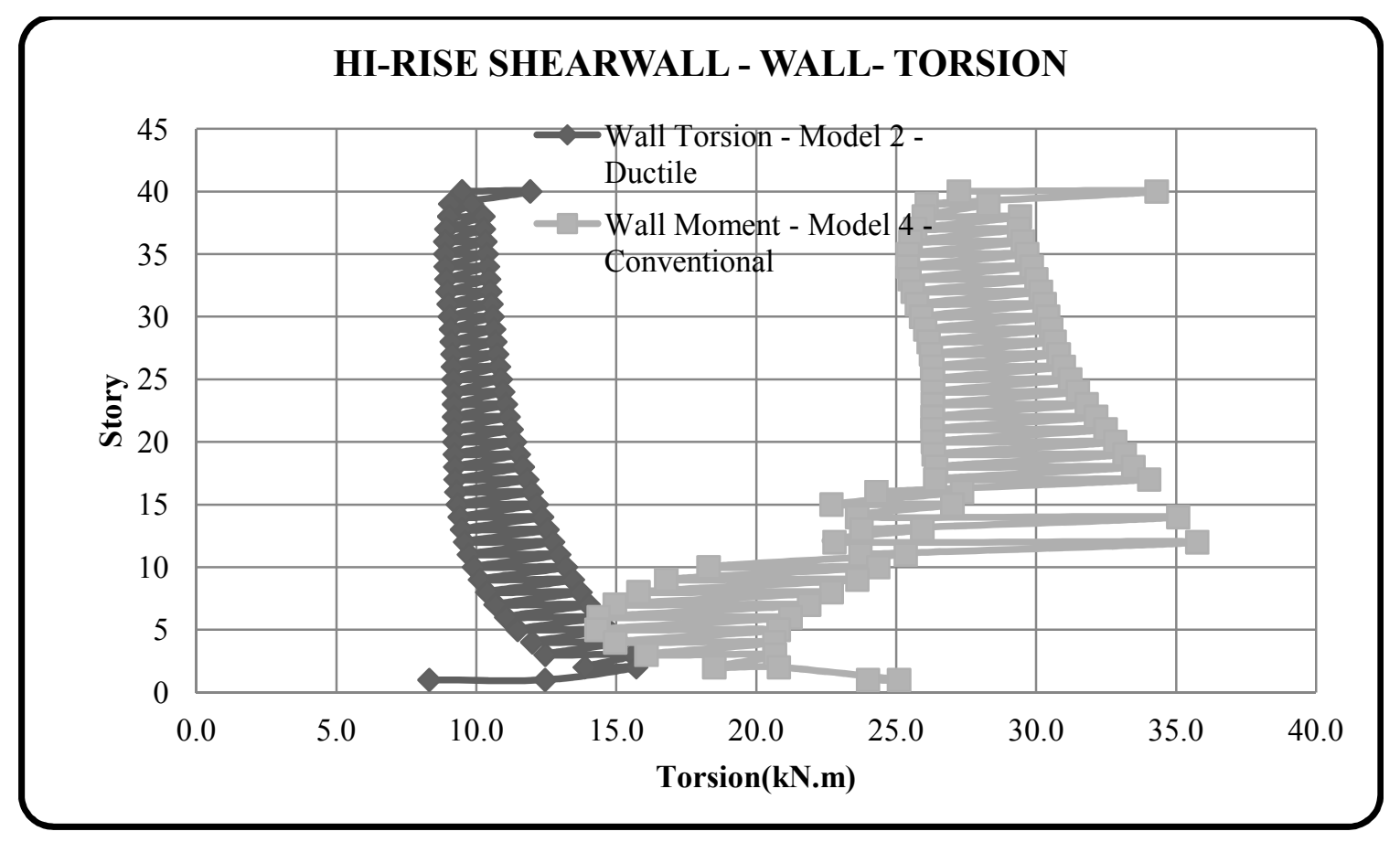

Figure 34: High Rise Shear Wall SFRS: WALL TORSION

\subsection{Member Forces: Moment Frame}

The exterior beam at the N-W corner of the building was selected to provide sample results. Based on the results shown in Figure 35 toFigure 34Figure 26, the following are notable observations:

1. As expected, the slope of the conventional construction curves is significantly steeper than the ductile curves. The beam forces distributed throughout the height of the building is much more uniform for the ductile configuration hence the member sizes and capacity demand is more uniform for the ductile configuration as opposed to conventional construction. This means that similar beam and slab thickness would be required on the lower floors for a ductile configuration as opposed to a conventional construction that would require significantly larger members on the lower floors in order to meet the capacity demand requirements.

2. The conventional construction configurations, especially in the taller buildings appear to be sensitive to torsional effects at the lower floors when exposed to dynamic earthquake force. This is likely a contributing factor for the $20 \mathrm{~m}$ and $40 \mathrm{~m}$ height limitation in regions of mid to high seismicity, $\leq 0.35\left(\mathrm{I}_{\mathrm{E}} \mathrm{FaSa}(0.2)\right) \leq 0.75$ for moment resisting frames and shear wall respectively. 


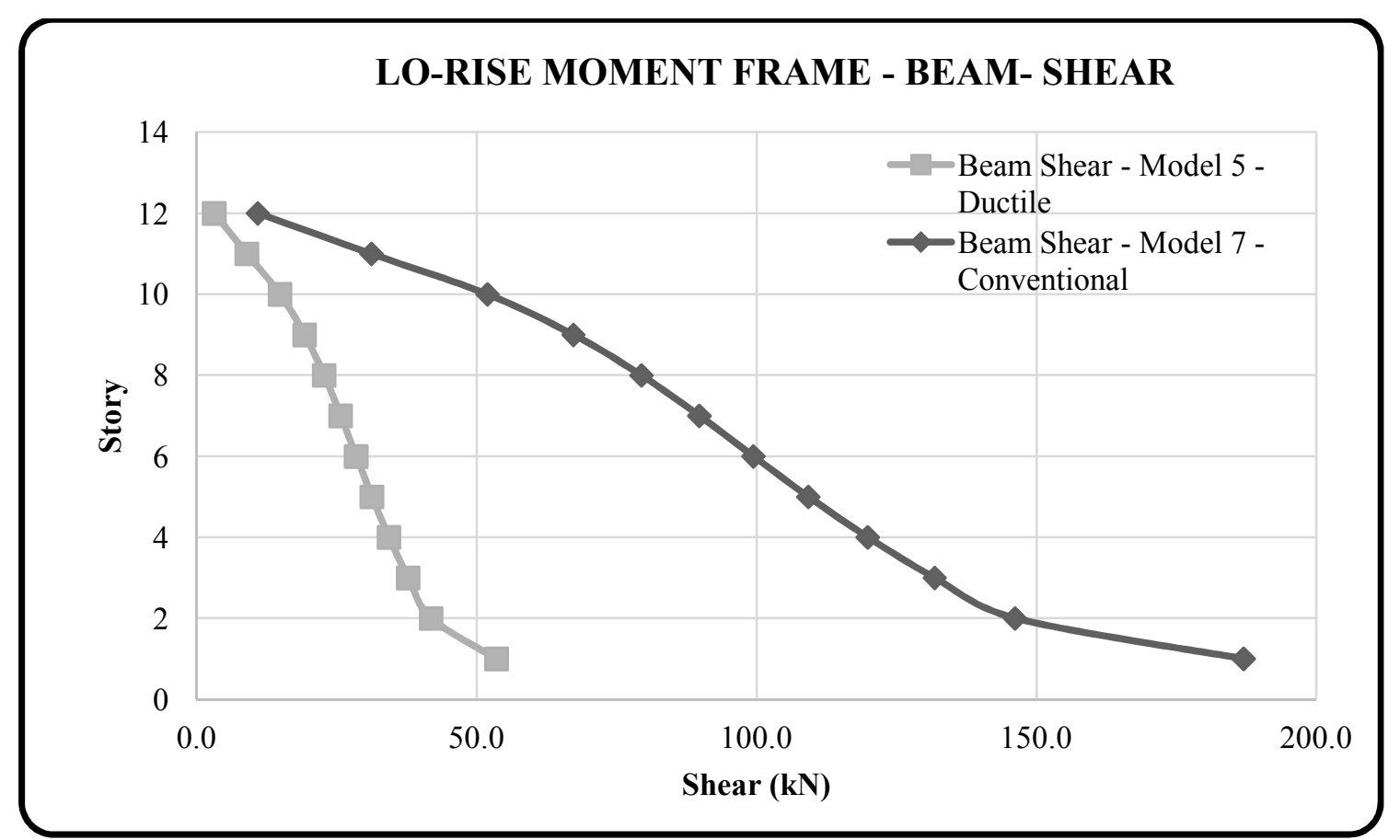

Figure 35: Low Rise Moment Frame SFRS: BEAM SHEAR

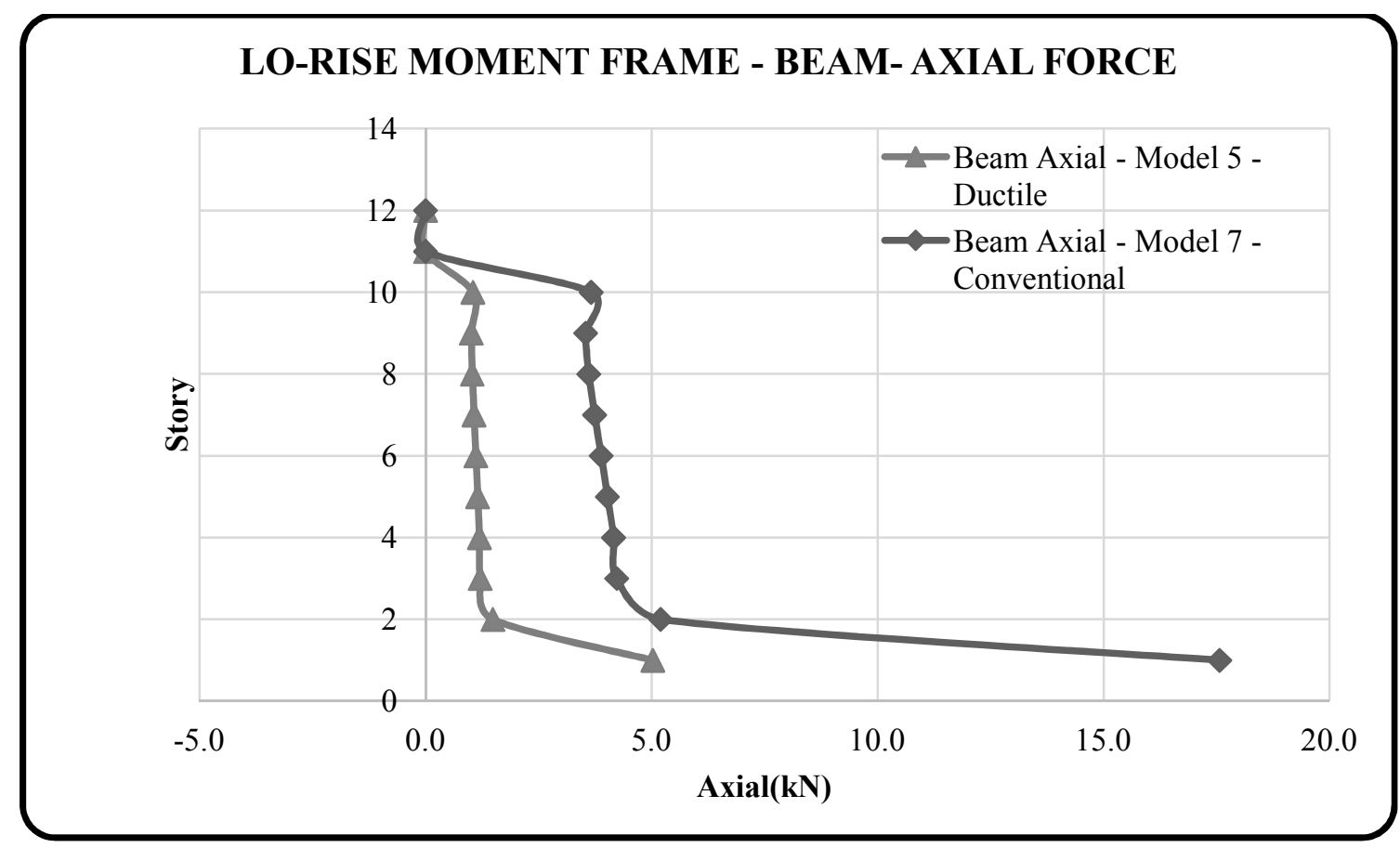

Figure 36: Low Rise Moment Frame SFRS: BEAM AXIAL FORCE 


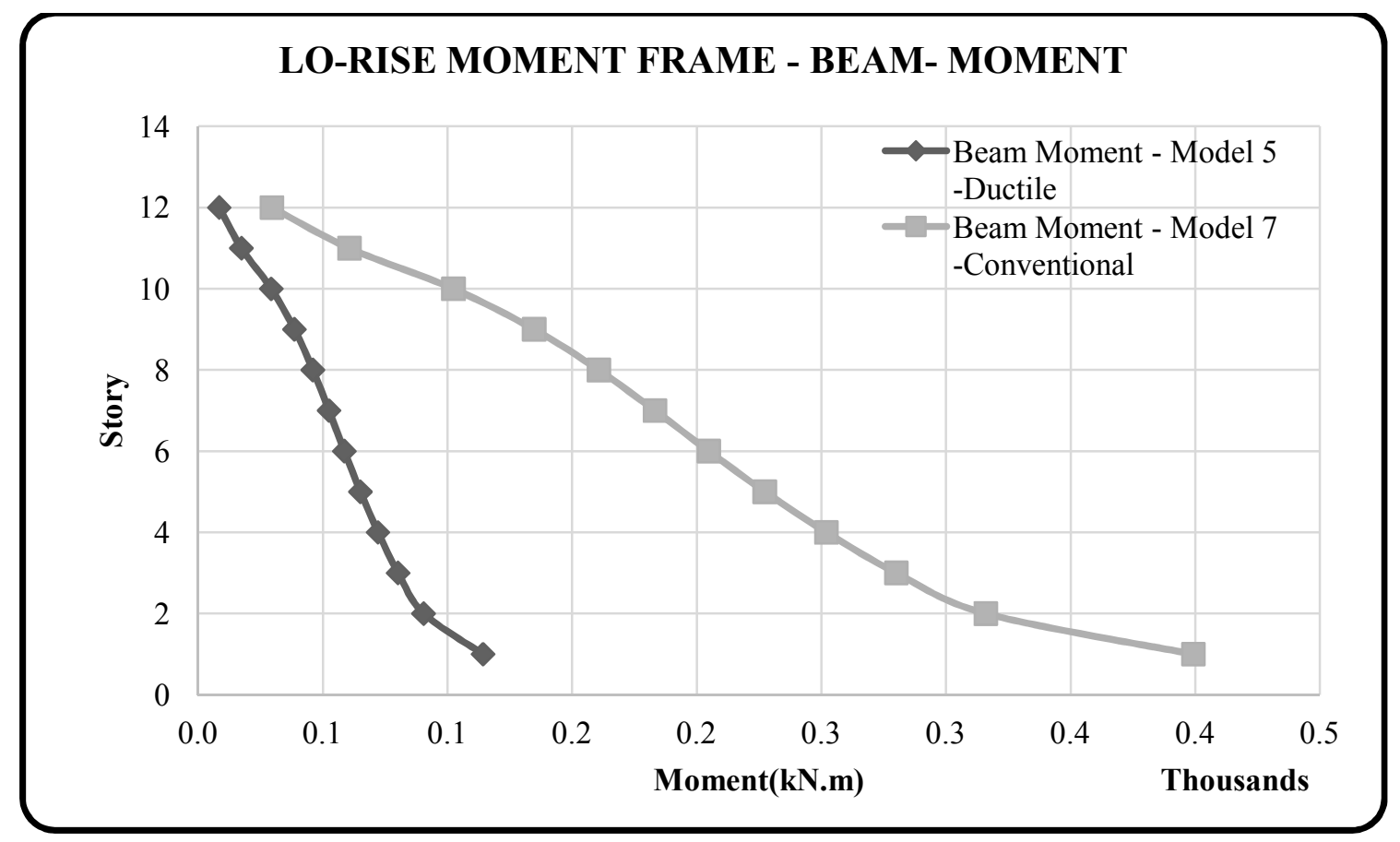

Figure 37: Low Rise Moment Frame SFRS: BEAM MOMENT

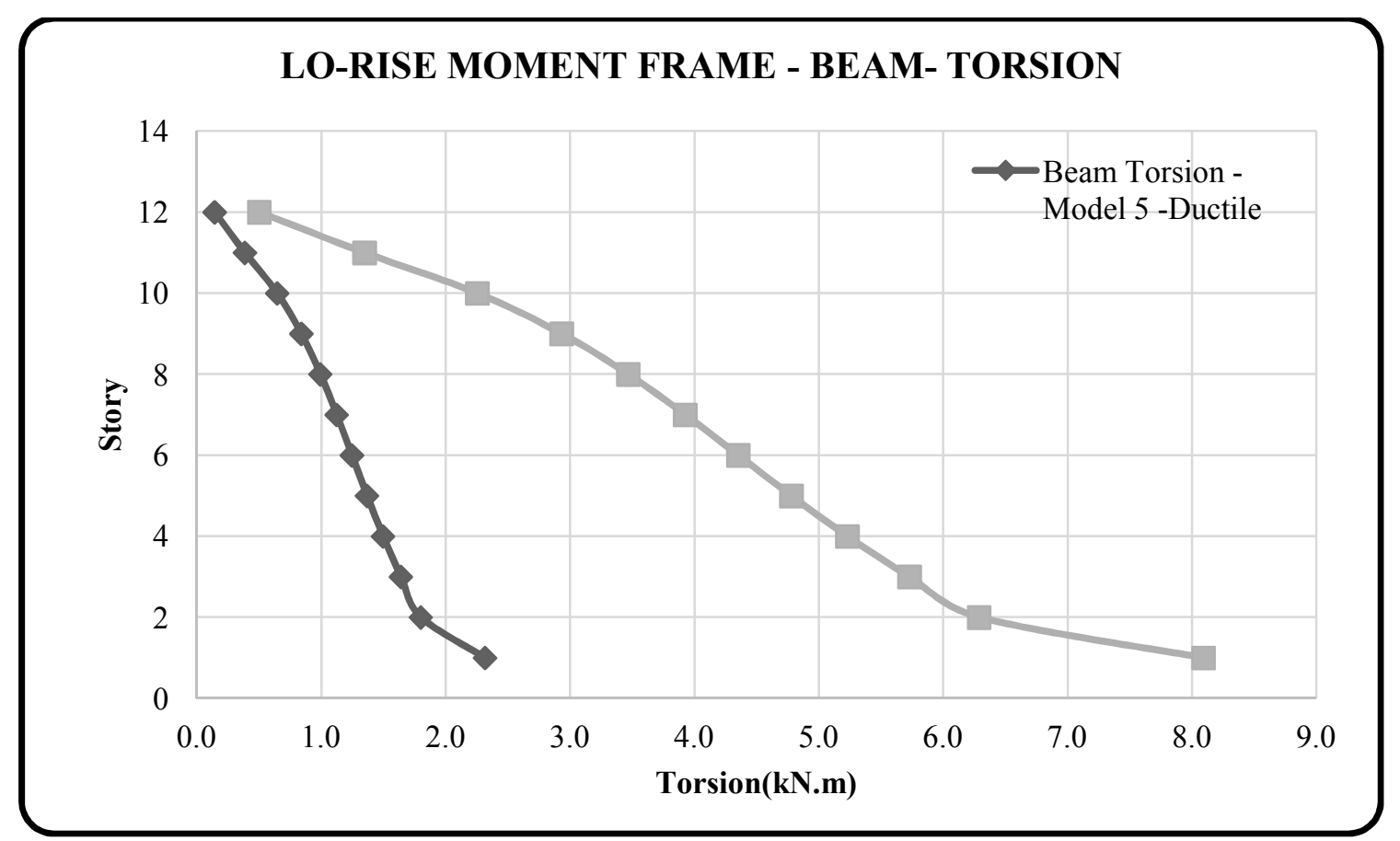

Figure 38: Low Rise Moment Frame SFRS: BEAM TORSION 


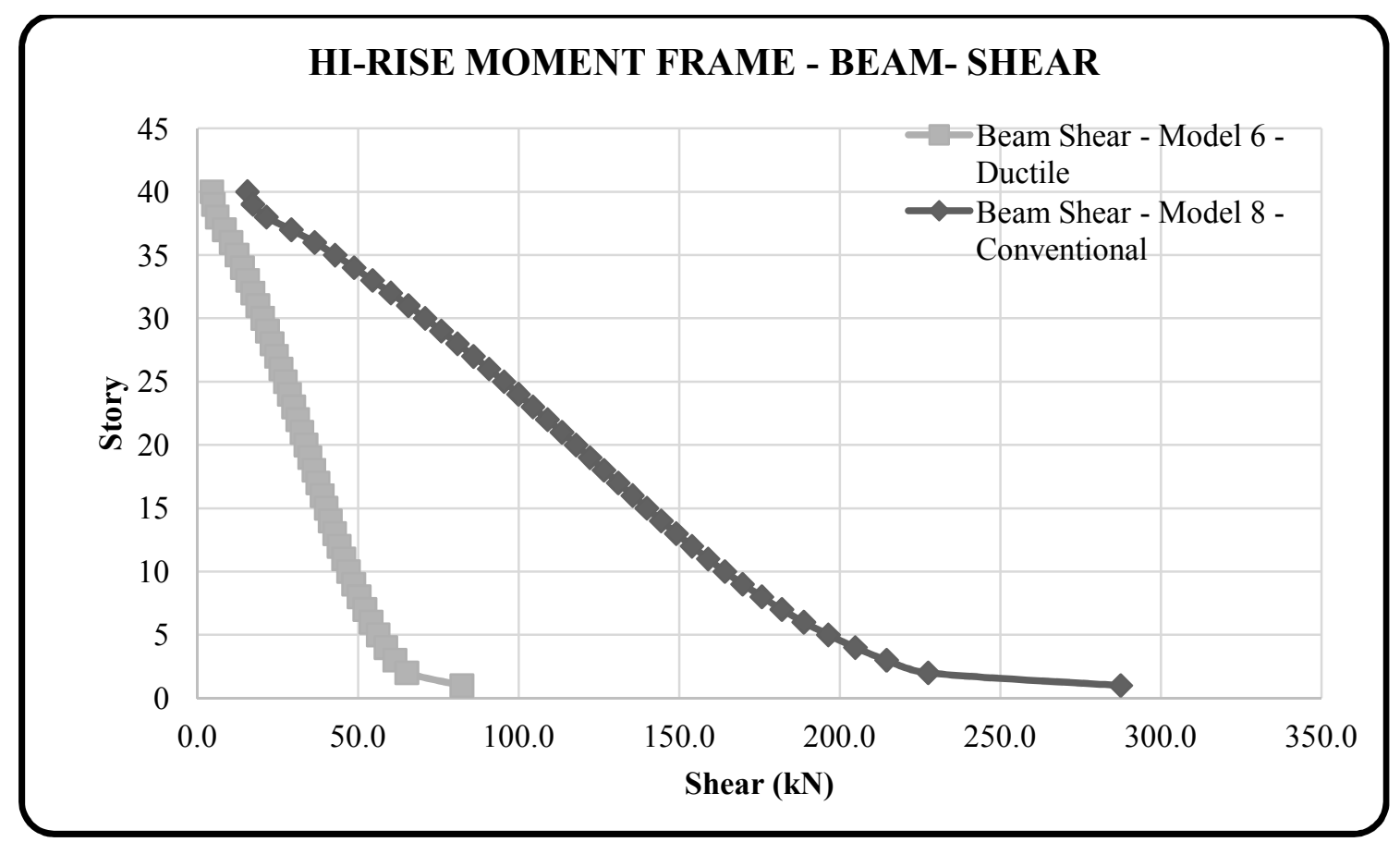

Figure 39: High Rise Moment Frame SFRS: BEAM SHEAR

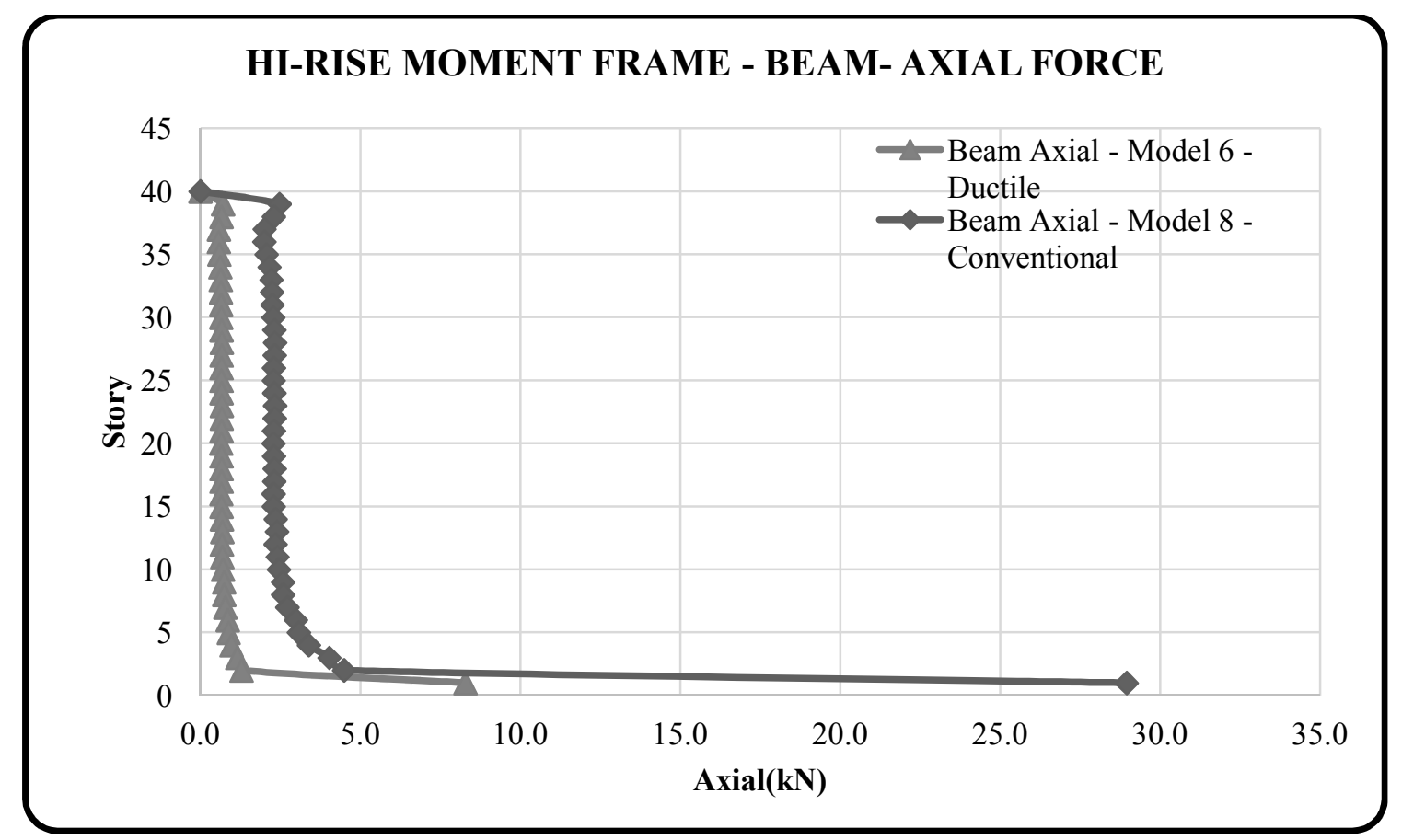

Figure 40: High Rise Moment Frame SFRS: BEAM AXIAL FORCE 


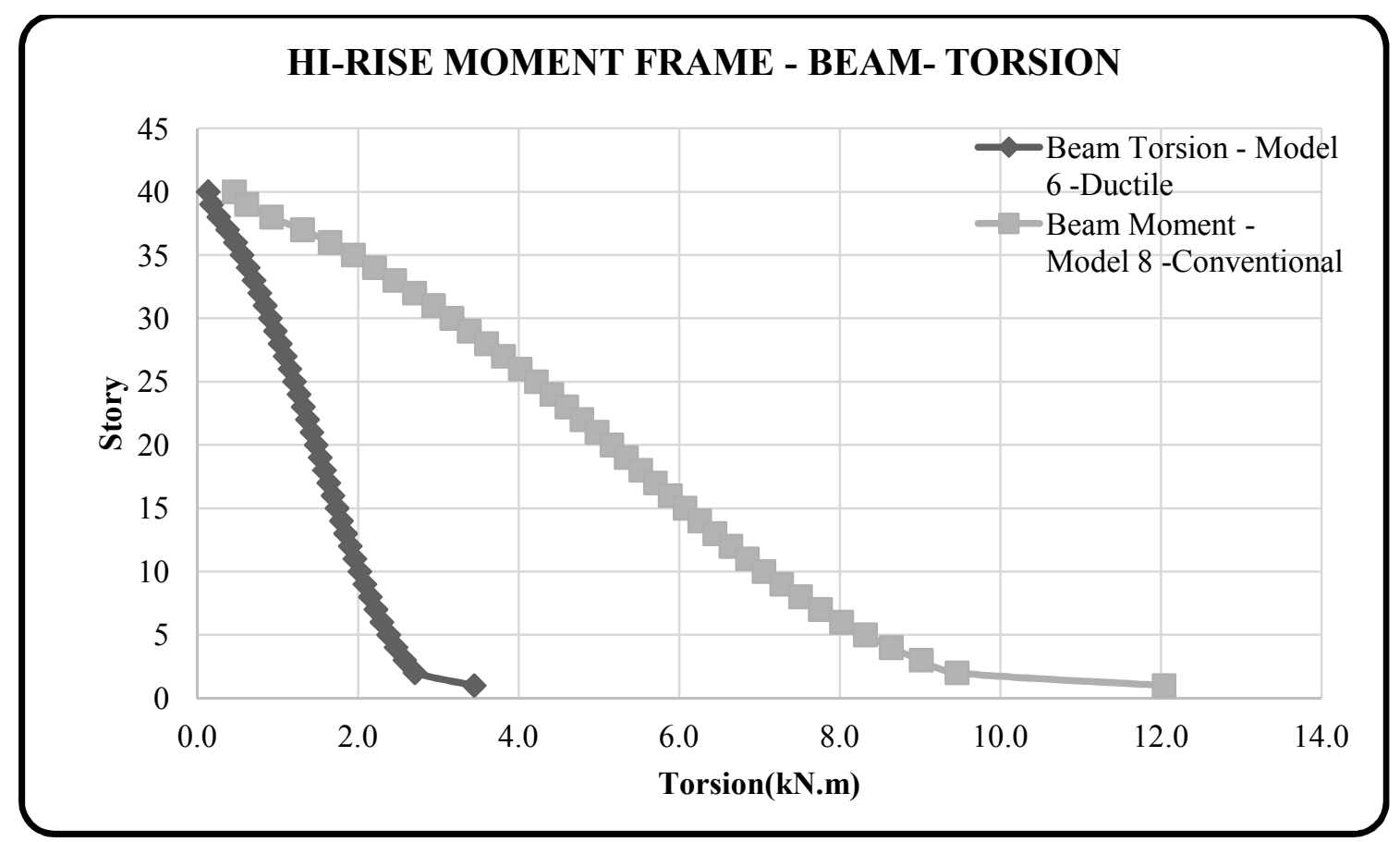

Figure 41: High Rise Moment Frame SFRS: BEAM TORSION

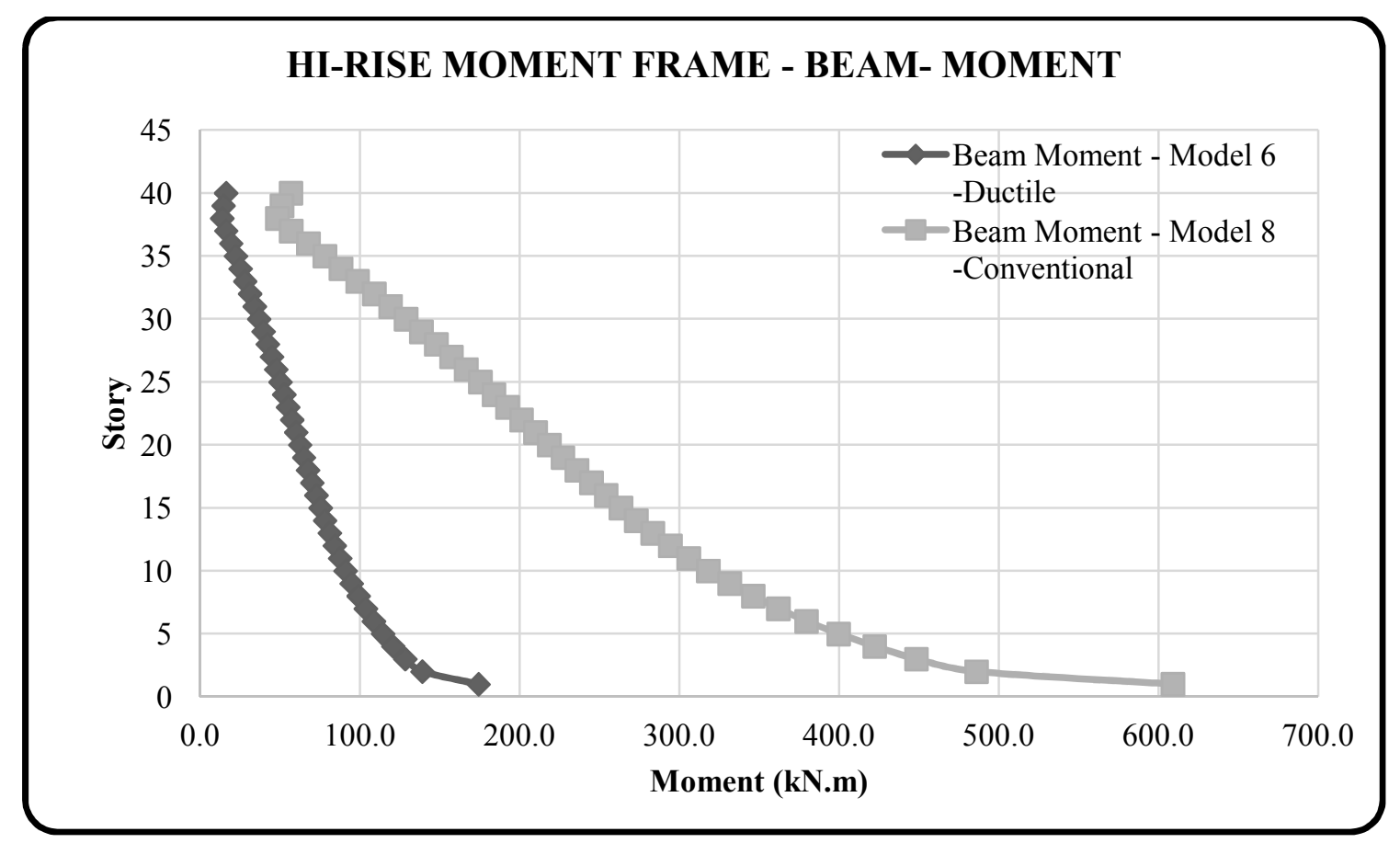

Figure 42: High Rise Moment Frame SFRS: BEAM MOMENT 


\section{Chapter 5 Conclusions and recommendations}

\subsection{Conclusions}

Response Spectrum Analysis of an assembly of 8 buildings located in Montreal, Quebec, with varying heights, SFRS types and ductility and overstrength factors was performed in Etabs. The obtained results from the dynamic analysis were also compared to the static Equivalent Lateral Force Procedure as stipulated in the NBCC 2015 Seismic code provisions. The following are conclusions deducted from the analysis and interpretation of the results.

1. For shear wall configurations, using RSA, the base shear of both the 12 and 40 story buildings are similar for both the ductile and conventional construction. While this result is unexpected, the significantly larger period for the 40 story structure, as well as the high ductility (flexibility) of both structures might account for these results. The higher the natural period of a structure is an indicator of higher flexibility, with ductile structures having smaller $\mathrm{k}$ values; hence the base shear tends to be smaller as well since generally flexible structures experiences lower accelerations than stiffer buildings.

2. For the 12 story buildings, the seismic base shear obtained through both the RSA and ELFP are within $20 \%$ or less discrepancy with the RSA results lower for both the ductile and conventional shear wall buildings. This result is also similar for the moment frame buildings as well. These results justify the NBCC code upper limit of $60 \mathrm{~m}$ in building height above base that can be designed using the static ELFP procedure.

3. The results obtained from the ELFP for the taller structure, $(147.2 \mathrm{~m})$ is overly conservative. It is observed that for the 40 story buildings, the seismic base shear obtained through the RSA and ELFP are markedly different. Again, this is an indication that the effect of the ductility of the building is magnified as building height increases due to the increase in the natural period. The results for the moment frame 40 storey buildings follow a similar pattern as well.

5. The lateral force distribution of shear walls and moment frames were similar, with the lateral loads distributed between the two systems according to their relative stiffness. However, in general, the two systems deform with their own characteristic shapes. The interaction between the two, particularly at the upper levels of the buildings, results in quite a different lateral load distribution.

6. The results obtained from the response spectrum analysis appear to be scaled linearly by the ratio of the RdRo factors of the SFSR configuration. This result is consistent with all 8 
models.

7. The shear wall and frame appear to display constant stiffness throughout the height of the structure based on the similar design of each floor.

4. The slope of the shear wall curves appear to be more steep that the moment frame curves as is expected as the shear wall acts as vertical cantilever column with a greater slope at the top.

5. As expected, the slope of the conventional construction curves is significantly steeper than the ductile curves. The wall forces distributed throughout the height of the building is much more uniform for the ductile configuration hence the member sizes and capacity demand is more uniform for the ductile configuration as opposed to conventional construction. This means that similar wall and slab thickness would be required on the lower floors for a ductile configuration as opposed to a conventional construction that would require significantly larger members on the lower floors in order to meet the capacity demand requirements.

6. The conventional construction configurations, especially in the taller buildings appear to be sensitive to torsional effects at the lower floors when exposed to dynamic earthquake force. This is likely a contributing factor for the $20 \mathrm{~m}$ and $40 \mathrm{~m}$ height limitation in regions of mid to high seismicity, $\leq 0.35\left(\mathrm{I}_{\mathrm{E}} \mathrm{FaSa}(0.2)\right) \leq 0.75$ for moment resisting frames and shear wall respectively.

\subsection{Limitations of the Study}

1. Only the effects of the horizontal force were considered.

2. The practical limitations of mathematical response spectrum analysis modeling including interacting effects of inelastic elements to determine the effects of ductility and plastic hinge development demands, strong column-weak beam demands, etc was not performed.

3. The performance / capacity demand and design was outside the scope of this study.

4. The hysteretic behavior of members was assumed which might pose limitations on the results obtained.

5. Soil structure and foundation interactions were not considered.

6. The accidental torsional effects as per NBCC 2015 Seismic Code provisions were also outside the scope of this study. 


\subsection{Recommendations for further study}

1. A non-linear time history analysis of the eight buildings to determine the inelastic deformation demands such as the criteria for "Strong Column - Weak Beam" or the high ductility demands of the moment frame joints and the column/beam capacity ratio.

2. An in-depth review of the detailing and design requirements per CSA A23.3-14 code provisions to achieve high ductility in the respective concrete SFRS. An overall cost comparison of the ductile and conventional framed building would also be worthwhile.

3. The inclusion of the wind load in addition to the earthquake load to compare the seismic shear demands with the wind shears.

4. Further study of the effects of structural irregularities such as Vertical Stiffness, Weight (Mass), or Out-of-Plane offset irregularities on the results obtained. 
Appendix A: Plans, Elevations, Material \& Section properties and Loading

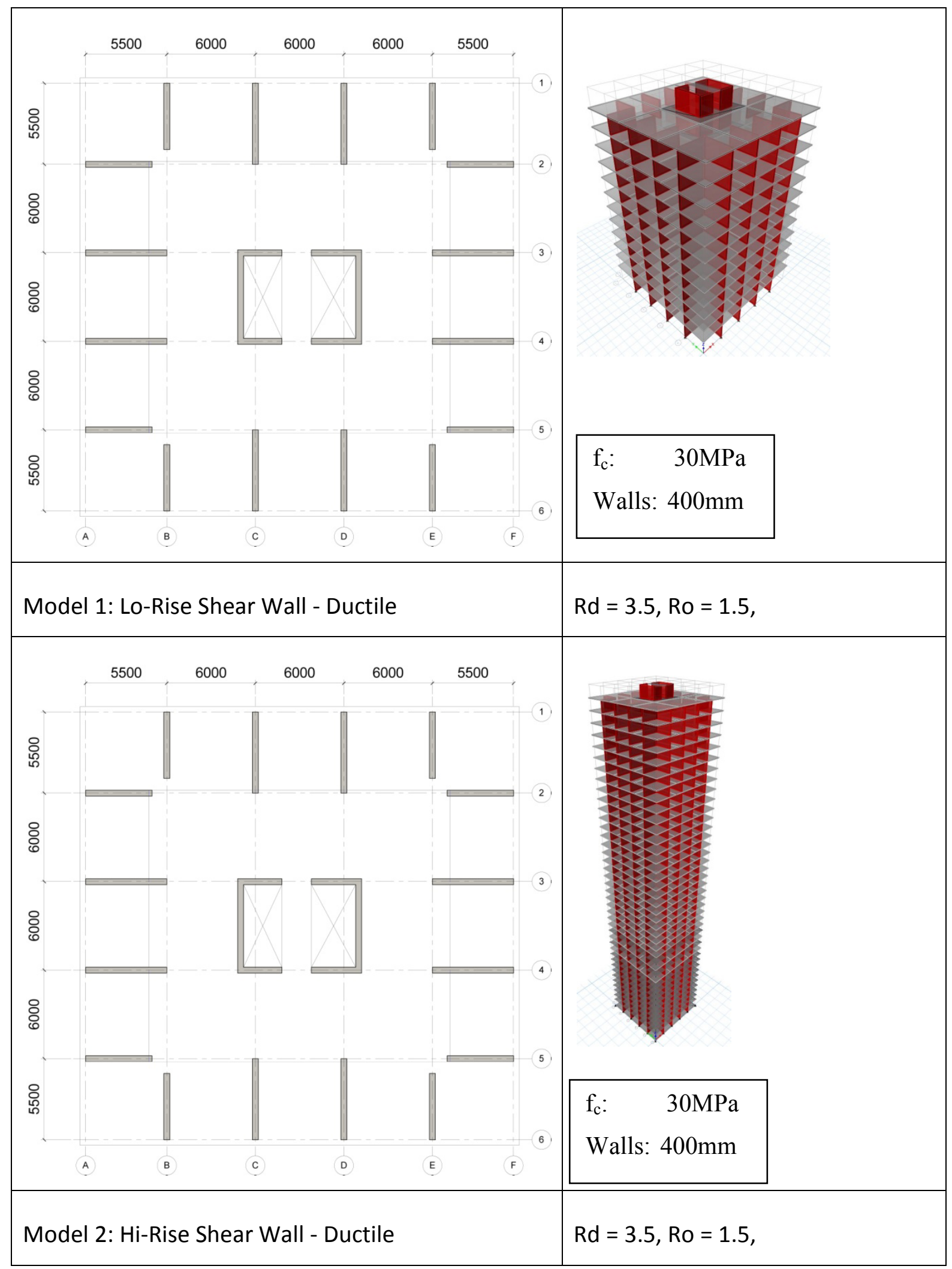




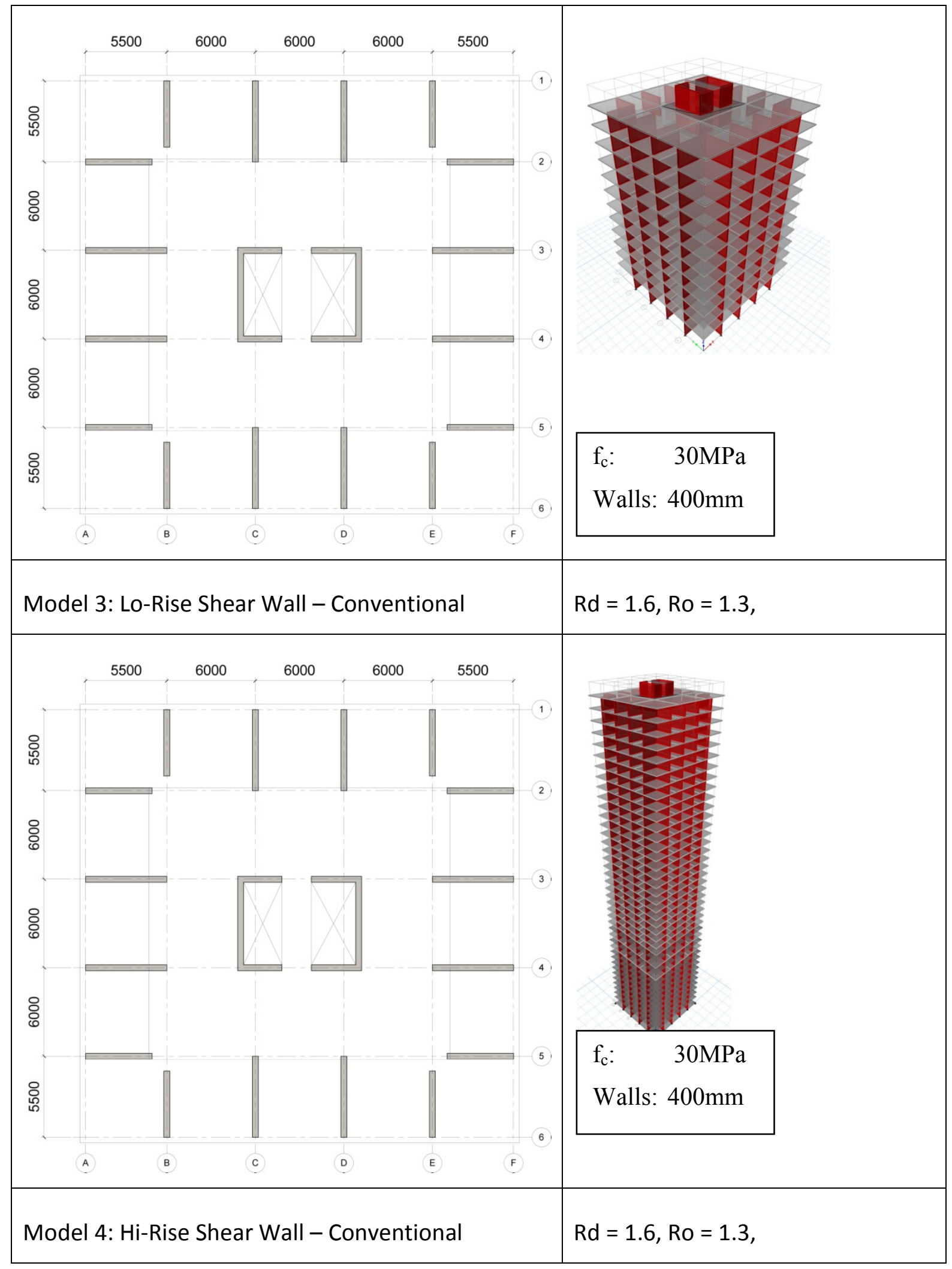




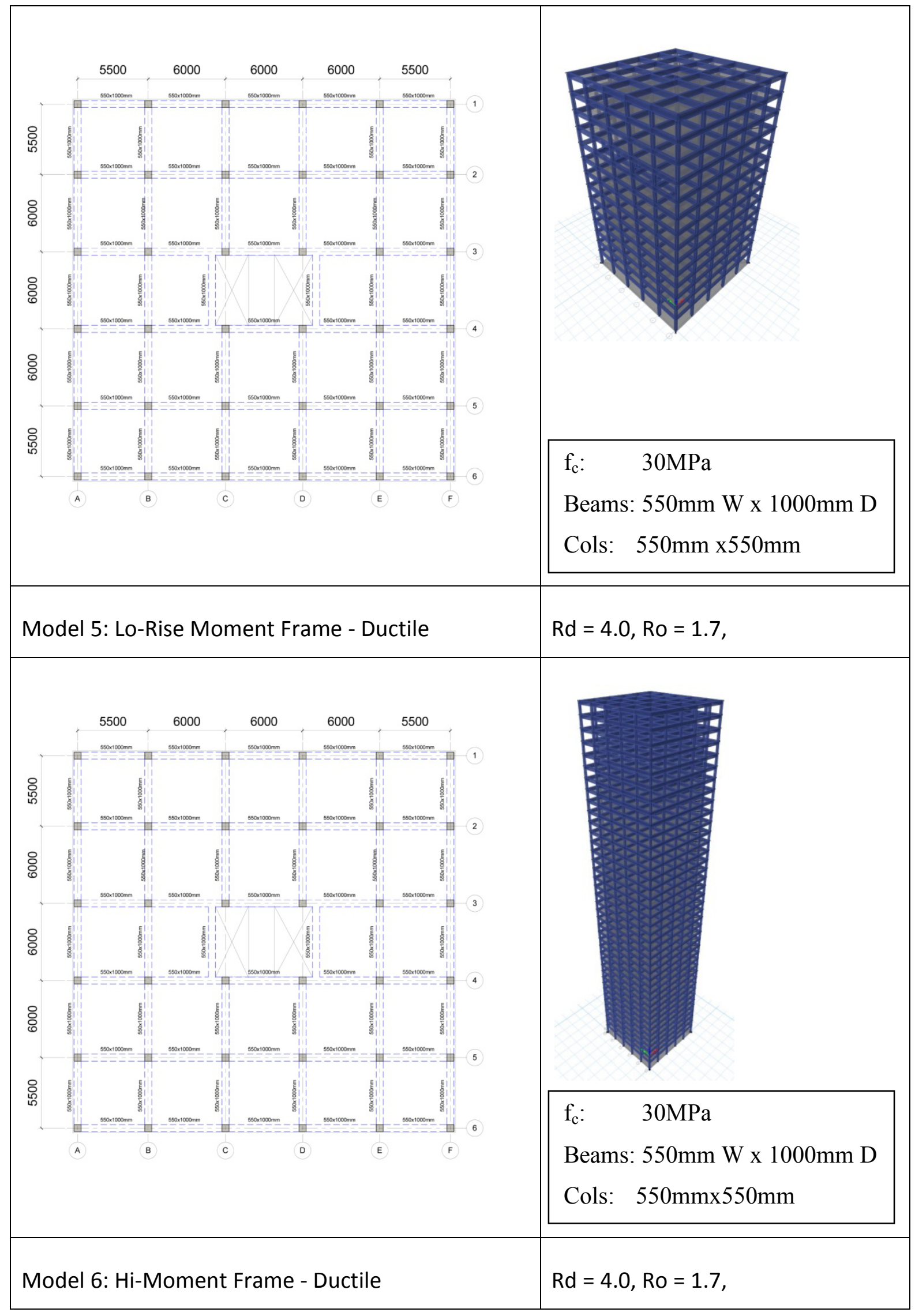




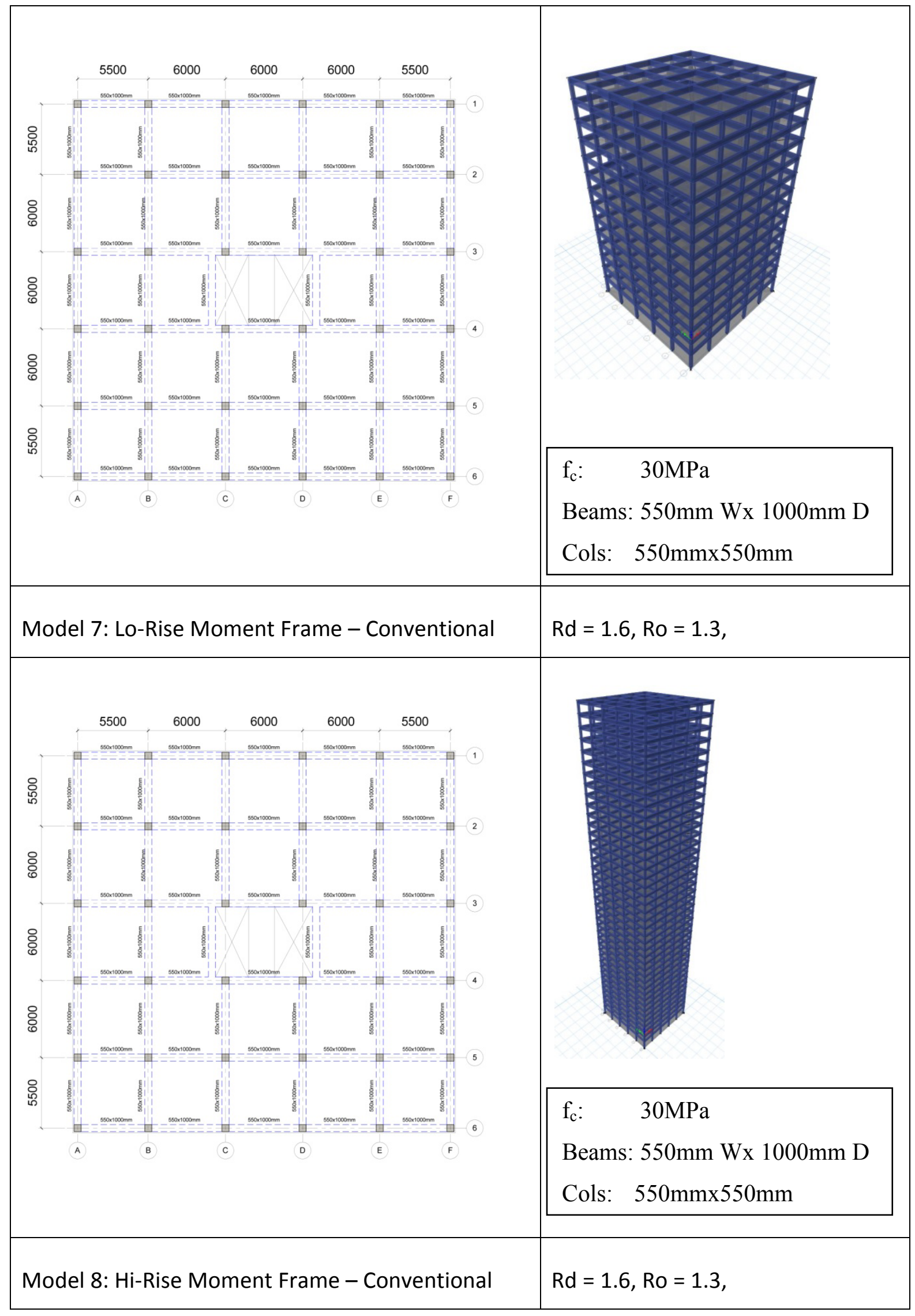


Appendix B: Response Spectrum Analysis Results

Part I - Concrete Shear Wall - Low - Rise (Ductile /Conventional Framing)

\begin{tabular}{|c|c|c|}
\hline \multicolumn{3}{|c|}{ STORY DRIFTS } \\
\hline & MODEL 1 & MODEL 3 \\
\hline Story & Drift (m) & Drift (m) \\
\hline 12 & 0.000515 & 0.001481 \\
\hline 11 & 0.000518 & 0.001488 \\
\hline 10 & 0.000515 & 0.001481 \\
\hline 9 & 0.000506 & 0.001456 \\
\hline 8 & 0.00049 & 0.001408 \\
\hline 7 & 0.000466 & 0.001339 \\
\hline 6 & 0.000434 & 0.001248 \\
\hline 5 & 0.000394 & 0.001132 \\
\hline 4 & 0.000344 & 0.000988 \\
\hline 3 & 0.000281 & 0.000809 \\
\hline 2 & 0.000205 & 0.000588 \\
\hline 1 & 0.000097 & 0.000278 \\
\hline
\end{tabular}

\begin{tabular}{|c|c|c|c|c|c|c|}
\hline \multicolumn{7}{|c|}{ BASE REACTIONS - MODEL 1} \\
\hline Load Case/Combo & FX & FY & FZ & MX & MY & MZ \\
\hline & $\mathrm{kN}$ & $\mathrm{kN}$ & $\mathrm{kN}$ & $\mathrm{kN}-\mathrm{m}$ & $\mathrm{kN}-\mathrm{m}$ & $\mathrm{kN}-\mathrm{m}$ \\
\hline SPECX1 Max & 3749 & 4050 & 0 & 92124 & 83619 & 66162 \\
\hline \multicolumn{7}{|c|}{ BASE REACTIONS - MODEL 3} \\
\hline Load Case/Combo & FX & FY & FZ & MX & MY & MZ \\
\hline & $\mathrm{kN}$ & $\mathrm{kN}$ & $\mathrm{kN}$ & $\mathrm{kN}-\mathrm{m}$ & $\mathrm{kN}-\mathrm{m}$ & $\mathrm{kN}-\mathrm{m}$ \\
\hline SPECX1 Max & 10775 & 11641 & 0 & 264789 & 240345 & 190033 \\
\hline
\end{tabular}




\begin{tabular}{|c|c|c|c|c|c|c|}
\hline \multicolumn{7}{|c|}{ STORY FORCES - MODEL 1} \\
\hline Story & Location & VX & VY & $\mathbf{T}$ & MX & MY \\
\hline & & $\mathrm{kN}$ & $\mathrm{kN}$ & $\mathrm{kN}-\mathrm{m}$ & $\mathrm{kN}-\mathrm{m}$ & $\mathrm{kN}-\mathrm{m}$ \\
\hline 12 & Top & 892 & 921 & 15268 & 262 & 278 \\
\hline 12 & Bottom & 1053 & 1094 & 18083 & 3948 & 3832 \\
\hline 11 & Top & 1492 & 1575 & 25803 & 3948 & 3832 \\
\hline 11 & Bottom & 1571 & 1665 & 27229 & 9854 & 9405 \\
\hline 10 & Top & 1765 & 1891 & 30776 & 9854 & 9405 \\
\hline 10 & Bottom & 1797 & 1929 & 31380 & 16690 & 15745 \\
\hline 9 & Top & 1868 & 2019 & 32811 & 16689 & 15744 \\
\hline 9 & Bottom & 1878 & 2034 & 33055 & 23653 & 22116 \\
\hline 8 & Top & 1910 & 2082 & 33816 & 23652 & 22115 \\
\hline 8 & Bottom & 1921 & 2097 & 34059 & 30353 & 28161 \\
\hline 7 & Top & 1996 & 2185 & 35478 & 30352 & 28159 \\
\hline 7 & Bottom & 2027 & 2220 & 36046 & 36735 & 33836 \\
\hline 6 & Top & 2193 & 2400 & 38964 & 36733 & 33834 \\
\hline 6 & Bottom & 2249 & 2461 & 39949 & 43044 & 39393 \\
\hline 5 & Top & 2496 & 2726 & 44236 & 43043 & 39391 \\
\hline 5 & Bottom & 2570 & 2805 & 45509 & 49748 & 45291 \\
\hline 4 & Top & 2859 & 3111 & 50491 & 49747 & 45288 \\
\hline 4 & Bottom & 2937 & 3194 & 51843 & 57364 & 52045 \\
\hline 3 & Top & 3219 & 3492 & 56707 & 57363 & 52043 \\
\hline 3 & Bottom & 3289 & 3566 & 57921 & 66274 & 60045 \\
\hline 2 & Top & 3518 & 3807 & 61916 & 66273 & 60043 \\
\hline 2 & Bottom & 3568 & 3860 & 62804 & 76590 & 69407 \\
\hline 1 & Top & 3708 & 4007 & 65354 & 76589 & 69405 \\
\hline 1 & Bottom & 3749 & 4050 & 66162 & 92124 & 83619 \\
\hline
\end{tabular}




\begin{tabular}{|c|c|c|c|c|c|c|}
\hline \multicolumn{7}{|c|}{ STORY FORCES - MODEL 3} \\
\hline Story & Location & $\mathbf{V X}$ & $\mathbf{V Y}$ & $\mathbf{T}$ & MX & MY \\
\hline & & $\mathrm{kN}$ & $\mathrm{kN}$ & $\mathrm{kN}-\mathrm{m}$ & $\mathrm{kN}-\mathrm{m}$ & $\mathrm{kN}-\mathrm{m}$ \\
\hline 12 & Top & 2563 & 2648 & 43852 & 753 & 799 \\
\hline 12 & Bottom & 3028 & 3145 & 51936 & 11349 & 11016 \\
\hline 11 & Top & 4287 & 4528 & 74110 & 11349 & 11016 \\
\hline 11 & Bottom & 4516 & 4787 & 78205 & 28324 & 27034 \\
\hline 10 & Top & 5074 & 5435 & 88393 & 28322 & 27032 \\
\hline 10 & Bottom & 5166 & 5544 & 90127 & 47972 & 45256 \\
\hline 9 & Top & 5368 & 5803 & 94240 & 47969 & 45253 \\
\hline 9 & Bottom & 5398 & 5847 & 94940 & 67985 & 63568 \\
\hline 8 & Top & 5489 & 5985 & 97128 & 67981 & 63564 \\
\hline 8 & Bottom & 5522 & 6028 & 97824 & 87244 & 80942 \\
\hline 7 & Top & 5737 & 6280 & 101900 & 87240 & 80938 \\
\hline 7 & Bottom & 5827 & 6381 & 103533 & 105586 & 97254 \\
\hline 6 & Top & 6302 & 6898 & 111913 & 105581 & 97249 \\
\hline 6 & Bottom & 6464 & 7073 & 114743 & 123722 & 113226 \\
\hline 5 & Top & 7174 & 7835 & 127055 & 123717 & 113220 \\
\hline 5 & Bottom & 7386 & 8061 & 130712 & 142991 & 130178 \\
\hline 4 & Top & 8217 & 8943 & 145021 & 142986 & 130171 \\
\hline 4 & Bottom & 8443 & 9182 & 148902 & 164882 & 149593 \\
\hline 3 & Top & 9252 & 10037 & 162874 & 164876 & 149587 \\
\hline 3 & Bottom & 9453 & 10249 & 166359 & 190491 & 172585 \\
\hline 2 & Top & 10112 & 10942 & 177835 & 190487 & 172580 \\
\hline 2 & Bottom & 10256 & 11094 & 180385 & 220141 & 199495 \\
\hline 1 & Top & 10658 & 11517 & 187712 & 220138 & 199491 \\
\hline 1 & Bottom & 10775 & 11641 & 190033 & 264789 & 240345 \\
\hline
\end{tabular}




\begin{tabular}{|c|c|c|c|c|c|c|}
\hline \multicolumn{7}{|c|}{ WALL FORCES - MODEL 1} \\
\hline Story & Pier & Location & $\mathbf{P}(\mathbf{k N})$ & V2(kN) & T(kN.m) & M3(kN.m) \\
\hline 12 & W17 & Top & 158 & 178.98 & 6.59 & 377.09 \\
\hline 12 & W17 & Bottom & 259 & 185.03 & 9.17 & 232.78 \\
\hline 11 & W17 & Top & 414 & 205.51 & 6.13 & 264.41 \\
\hline 11 & W17 & Bottom & 617 & 211.37 & 6.88 & 393.76 \\
\hline 10 & W17 & Top & 816 & 237.55 & 5.95 & 271.76 \\
\hline 10 & W17 & Bottom & 1044 & 241.26 & 7.22 & 586.86 \\
\hline 9 & W17 & Top & 1257 & 250.89 & 5.64 & 342.01 \\
\hline 9 & W17 & Bottom & 1492 & 253.53 & 7.36 & 759.9 \\
\hline 8 & W17 & Top & 1705 & 256.35 & 6.22 & 463.08 \\
\hline 8 & W17 & Bottom & 1935 & 259.47 & 7.61 & 904.98 \\
\hline 7 & W17 & Top & 2142 & 265.5 & 8.05 & 590.6 \\
\hline 7 & W17 & Bottom & 2366 & 270.17 & 7.66 & 1027.7 \\
\hline 6 & W17 & Top & 2571 & 286.04 & 9.59 & 705.41 \\
\hline 6 & W17 & Bottom & 2800 & 292.3 & 7.53 & 1142.6 \\
\hline 5 & W17 & Top & 3017 & 318.47 & 10.5 & 810.13 \\
\hline 5 & W17 & Bottom & 3266 & 325.95 & 7.51 & 1271.9 \\
\hline 4 & W17 & Top & 3514 & 355.61 & 10.6 & 923.01 \\
\hline 4 & W17 & Bottom & 3799 & 364.31 & 8.11 & 1439.9 \\
\hline 3 & W17 & Top & 4089 & 386.57 & 9.59 & 1071.7 \\
\hline 3 & W17 & Bottom & 4413 & 396.78 & 9.94 & 1669.1 \\
\hline 2 & W17 & Top & 4737 & 393.47 & 7.41 & 1284.7 \\
\hline 2 & W17 & Bottom & 5077 & 403.85 & 12.8 & 1970.1 \\
\hline 1 & W17 & Top & 5367 & 401.75 & 17.1 & 1591.6 \\
\hline 1 & W17 & Bottom & 5890 & 426.27 & 13.4 & 2743.3 \\
\hline \multicolumn{7}{|c|}{ WALL FORCES - MODEL 3} \\
\hline Story & Pier & Location & $\mathbf{P}(\mathbf{k N})$ & $\mathbf{V 2}(\mathbf{k N})$ & T(kN.m) & M3(kN.m) \\
\hline 12 & W17 & Top & 54.846 & 62.297 & 2.294 & 131.1985 \\
\hline 12 & W17 & Bottom & 90.267 & 64.402 & 3.194 & 81.0161 \\
\hline 11 & W17 & Top & 144.09 & 71.548 & 2.134 & 92.0177 \\
\hline 11 & W17 & Bottom & 214.62 & 73.587 & 2.394 & 137.0226 \\
\hline 10 & W17 & Top & 283.85 & 82.701 & 2.07 & 94.5871 \\
\hline
\end{tabular}




\begin{tabular}{|c|c|c|c|c|c|c|}
\hline 10 & W17 & Bottom & 363.15 & 83.995 & 2.514 & 204.1981 \\
\hline 9 & W17 & Top & 437.26 & 87.348 & 1.963 & 119.0281 \\
\hline 9 & W17 & Bottom & 519.07 & 88.266 & 2.562 & 264.4002 \\
\hline 8 & W17 & Top & 593.12 & 89.252 & 2.167 & 161.1456 \\
\hline 8 & W17 & Bottom & 673.34 & 90.338 & 2.651 & 314.8744 \\
\hline 7 & W17 & Top & 745.17 & 92.44 & 2.801 & 205.5059 \\
\hline 7 & W17 & Bottom & 823.34 & 94.063 & 2.667 & 357.5546 \\
\hline 6 & W17 & Top & 894.63 & 99.59 & 3.338 & 245.4499 \\
\hline 6 & W17 & Bottom & 974.06 & 101.77 & 2.623 & 397.5562 \\
\hline 5 & W17 & Top & 1049.8 & 110.88 & 3.662 & 281.8899 \\
\hline 5 & W17 & Bottom & 1136.3 & 113.48 & 2.616 & 442.5275 \\
\hline 4 & W17 & Top & 1222.7 & 123.8 & 3.675 & 321.1651 \\
\hline 4 & W17 & Bottom & 1321.7 & 126.84 & 2.825 & 500.9785 \\
\hline 3 & W17 & Top & 1422.7 & 134.58 & 3.338 & 372.9083 \\
\hline 3 & W17 & Bottom & 1535.4 & 138.14 & 3.458 & 580.7475 \\
\hline 2 & W17 & Top & 1648.3 & 136.99 & 2.58 & 446.9937 \\
\hline 2 & W17 & Bottom & 1766.4 & 140.61 & 4.45 & 685.4367 \\
\hline 1 & W17 & Top & 1867.4 & 139.84 & 5.943 & 553.7638 \\
\hline 1 & W17 & Bottom & 2049.4 & 148.37 & 4.675 & 954.4202 \\
\hline & & & & & & \\
\hline
\end{tabular}


Part II - Concrete Shear Wall - High - Rise (Ductile /Conventional Framing)

\begin{tabular}{|c|c|c|c|c|c|}
\hline \multicolumn{6}{|c|}{ STORY DRIFTS } \\
\hline & MODEL 2 & MODEL 4 & & MODEL 2 & MODEL 4 \\
\hline Story & Drift (m) & Drift (m) & Story & Drift (m) & Drift (m) \\
\hline 40 & 0.001783 & 0.005128 & 20 & 0.001976 & 0.00569 \\
\hline 39 & 0.001793 & 0.005158 & 19 & 0.001955 & 0.005631 \\
\hline 38 & 0.001805 & 0.005194 & 18 & 0.001929 & 0.005555 \\
\hline 37 & 0.00182 & 0.005237 & 17 & 0.001896 & 0.00546 \\
\hline 36 & 0.001836 & 0.005285 & 16 & 0.001856 & 0.005349 \\
\hline 35 & 0.001854 & 0.005337 & 15 & 0.00181 & 0.005211 \\
\hline 34 & 0.001872 & 0.005391 & 14 & 0.001755 & 0.005067 \\
\hline 33 & 0.001891 & 0.005445 & 13 & 0.001694 & 0.004882 \\
\hline 32 & 0.00191 & 0.005499 & 12 & 0.001624 & 0.004691 \\
\hline 31 & 0.001928 & 0.005551 & 11 & 0.001545 & 0.004456 \\
\hline 30 & 0.001945 & 0.0056 & 10 & 0.001458 & 0.004199 \\
\hline 29 & 0.001961 & 0.005646 & 9 & 0.001361 & 0.003921 \\
\hline 28 & 0.001976 & 0.005687 & 8 & 0.001255 & 0.003614 \\
\hline 27 & 0.001988 & 0.005722 & 7 & 0.001138 & 0.003277 \\
\hline 26 & 0.001997 & 0.00575 & 6 & 0.001011 & 0.00291 \\
\hline 25 & 0.002004 & 0.005769 & 5 & 0.000872 & 0.002511 \\
\hline 24 & 0.002007 & 0.005778 & 4 & 0.000722 & 0.002078 \\
\hline 23 & 0.002006 & 0.005776 & 3 & 0.000558 & 0.001609 \\
\hline 22 & 0.002001 & 0.005762 & 2 & 0.000381 & 0.001098 \\
\hline 21 & 0.001991 & 0.005734 & 1 & 0.000153 & 0.000477 \\
\hline
\end{tabular}




\begin{tabular}{|c|c|c|c|c|c|c|}
\hline \multicolumn{7}{|c|}{ BASE REACTIONS - MODEL 2} \\
\hline \multirow[t]{2}{*}{ Load Case/Combo } & FX & FY & FZ & MX & MY & MZ \\
\hline & $\mathbf{k N}$ & $\mathbf{k N}$ & $\mathbf{k N}$ & kN-m & kN-m & $\mathbf{k N}-\mathbf{m}$ \\
\hline SPECX1 Max & 3350 & 3705 & 0 & 259285 & 263691 & 65090 \\
\hline \multicolumn{7}{|c|}{ BASE REACTIONS - MODEL 4} \\
\hline \multirow[t]{2}{*}{ Load Case/Combo } & FX & FY & FZ & MX & MY & MZ \\
\hline & $\mathbf{k N}$ & $\mathbf{k N}$ & $\mathbf{k N}$ & kN-m & kN-m & kN-m \\
\hline SPECX1 Max & 11968 & 14277 & 0 & 745131 & 756673 & 303333 \\
\hline
\end{tabular}

\begin{tabular}{|c|c|c|c|c|c|c|}
\hline \multicolumn{7}{|c|}{ STORY FORCES - MODEL 2} \\
\hline Story & Location & $\mathbf{V X}$ & $\mathbf{V Y}$ & $\mathbf{T}$ & MX & MY \\
\hline & & $\mathbf{k N}$ & $\mathbf{k N}$ & $\mathbf{k N}-\mathbf{m}$ & kN-m & kN-m \\
\hline 40 & Top & 476 & 510 & 7864 & 138 & 134 \\
\hline 40 & Bottom & 569 & 612 & 9461 & 2209 & 2063 \\
\hline 39 & Top & 847 & 926 & 14402 & 2209 & 2063 \\
\hline 39 & Bottom & 904 & 993 & 15470 & 5762 & 5305 \\
\hline 38 & Top & 1059 & 1183 & 18582 & 5762 & 5305 \\
\hline 38 & Bottom & 1087 & 1219 & 19208 & 10211 & 9277 \\
\hline 37 & Top & 1156 & 1312 & 20903 & 10211 & 9277 \\
\hline 37 & Bottom & 1168 & 1328 & 21220 & 15076 & 13536 \\
\hline 36 & Top & 1196 & 1363 & 22060 & 15076 & 13536 \\
\hline 36 & Bottom & 1202 & 1369 & 22226 & 20020 & 17814 \\
\hline 35 & Top & 1226 & 1384 & 22765 & 20020 & 17814 \\
\hline 35 & Bottom & 1233 & 1389 & 22910 & 24863 & 22004 \\
\hline 34 & Top & 1266 & 1409 & 23517 & 24863 & 22004 \\
\hline 34 & Bottom & 1276 & 1416 & 23704 & 29550 & 26105 \\
\hline 33 & Top & 1315 & 1448 & 24493 & 29550 & 26105 \\
\hline 33 & Bottom & 1326 & 1458 & 24727 & 34102 & 30165 \\
\hline 32 & Top & 1371 & 1496 & 25658 & 34102 & 30165 \\
\hline 32 & Bottom & 1383 & 1507 & 25921 & 38573 & 34246 \\
\hline
\end{tabular}




\begin{tabular}{|c|c|c|c|c|c|c|}
\hline 31 & Top & 1434 & 1549 & 26936 & 38573 & 34246 \\
\hline 31 & Bottom & 1448 & 1561 & 27215 & 43023 & 38414 \\
\hline 30 & Top & 1504 & 1609 & 28279 & 43023 & 38414 \\
\hline 30 & Bottom & 1520 & 1623 & 28569 & 47515 & 42739 \\
\hline 29 & Top & 1576 & 1676 & 29655 & 47515 & 42739 \\
\hline 29 & Bottom & 1591 & 1690 & 29946 & 52111 & 47284 \\
\hline 28 & Top & 1642 & 1744 & 31013 & 52111 & 47284 \\
\hline 28 & Bottom & 1656 & 1759 & 31292 & 56873 & 52095 \\
\hline 27 & Top & 1702 & 1808 & 32301 & 56873 & 52095 \\
\hline 27 & Bottom & 1714 & 1820 & 32561 & 61845 & 57196 \\
\hline 26 & Top & 1759 & 1863 & 33496 & 61845 & 57196 \\
\hline 26 & Bottom & 1771 & 1874 & 33737 & 67051 & 62598 \\
\hline 25 & Top & 1817 & 1912 & 34613 & 67051 & 62598 \\
\hline 25 & Bottom & 1829 & 1923 & 34842 & 72503 & 68311 \\
\hline 24 & Top & 1873 & 1962 & 35682 & 72503 & 68311 \\
\hline 24 & Bottom & 1884 & 1972 & 35904 & 78205 & 74339 \\
\hline 23 & Top & 1922 & 2012 & 36716 & 78205 & 74339 \\
\hline 23 & Bottom & 1932 & 2023 & 36928 & 84161 & 80676 \\
\hline 22 & Top & 1966 & 2060 & 37697 & 84161 & 80676 \\
\hline 22 & Bottom & 1975 & 2069 & 37895 & 90370 & 87309 \\
\hline 21 & Top & 2009 & 2100 & 38603 & 90370 & 87309 \\
\hline 21 & Bottom & 2018 & 2108 & 38784 & 96825 & 94222 \\
\hline 20 & Top & 2051 & 2135 & 39430 & 96825 & 94222 \\
\hline 20 & Bottom & 2060 & 2142 & 39597 & 103511 & 101400 \\
\hline 19 & Top & 2090 & 2170 & 40205 & 103511 & 101400 \\
\hline 19 & Bottom & 2097 & 2178 & 40365 & 110408 & 108826 \\
\hline 18 & Top & 2122 & 2206 & 40955 & 110408 & 108826 \\
\hline 18 & Bottom & 2128 & 2214 & 41111 & 117502 & 116476 \\
\hline 17 & Top & 2151 & 2241 & 41678 & 117502 & 116476 \\
\hline 17 & Bottom & 2158 & 2248 & 41824 & 124778 & 124327 \\
\hline 16 & Top & 2182 & 2272 & 42345 & 124778 & 124327 \\
\hline 16 & Bottom & 2189 & 2277 & 42478 & 132216 & 132353 \\
\hline
\end{tabular}




\begin{tabular}{|c|c|c|c|c|c|c|}
\hline 15 & Top & 2213 & 2300 & 42959 & 132216 & 132353 \\
\hline 15 & Bottom & 2219 & 2307 & 43087 & 139796 & 140535 \\
\hline 14 & Top & 2239 & 2333 & 43576 & 139796 & 140535 \\
\hline 14 & Bottom & 2244 & 2341 & 43713 & 147498 & 148847 \\
\hline 13 & Top & 2263 & 2373 & 44248 & 147498 & 148847 \\
\hline 13 & Bottom & 2269 & 2381 & 44396 & 155308 & 157264 \\
\hline 12 & Top & 2293 & 2413 & 44945 & 155308 & 157264 \\
\hline 12 & Bottom & 2300 & 2421 & 45090 & 163212 & 165762 \\
\hline 11 & Top & 2327 & 2454 & 45623 & 163212 & 165762 \\
\hline 11 & Bottom & 2334 & 2463 & 45769 & 171194 & 174320 \\
\hline 10 & Top & 2361 & 2506 & 46370 & 171194 & 174320 \\
\hline 10 & Bottom & 2368 & 2519 & 46555 & 179243 & 182918 \\
\hline 9 & Top & 2402 & 2578 & 47359 & 179243 & 182918 \\
\hline 9 & Bottom & 2414 & 2596 & 47604 & 187356 & 191535 \\
\hline 8 & Top & 2464 & 2667 & 48595 & 187356 & 191535 \\
\hline 8 & Bottom & 2480 & 2688 & 48877 & 195537 & 200159 \\
\hline 7 & Top & 2543 & 2770 & 49992 & 195537 & 200159 \\
\hline 7 & Bottom & 2561 & 2795 & 50321 & 203798 & 208785 \\
\hline 6 & Top & 2637 & 2901 & 51753 & 203798 & 208785 \\
\hline 6 & Bottom & 2660 & 2934 & 52204 & 212155 & 217412 \\
\hline 5 & Top & 2763 & 3063 & 54083 & 212155 & 217412 \\
\hline 5 & Bottom & 2794 & 3098 & 54609 & 220642 & 226048 \\
\hline 4 & Top & 2907 & 3219 & 56482 & 220642 & 226048 \\
\hline 4 & Bottom & 2936 & 3250 & 56956 & 229290 & 234710 \\
\hline 3 & Top & 3035 & 3366 & 58792 & 229290 & 234710 \\
\hline 3 & Bottom & 3064 & 3399 & 59357 & 238109 & 243402 \\
\hline 2 & Top & 3181 & 3524 & 61582 & 238109 & 243402 \\
\hline 2 & Bottom & 3205 & 3548 & 62011 & 247107 & 252120 \\
\hline 1 & Top & 3269 & 3617 & 63272 & 247107 & 252120 \\
\hline 1 & Bottom & 3349 & 3705 & 65087 & 259285 & 263691 \\
\hline
\end{tabular}


STORY FORCES - MODEL 4

\begin{tabular}{|c|c|c|c|c|c|c|}
\hline Story & Location & VX & VY & $\mathbf{T}$ & MX & MY \\
\hline & & kN & $\mathbf{k N}$ & kN-m & kN-m & kN-m \\
\hline 40 & Top & 814 & 960 & 14836 & 243 & 207 \\
\hline 40 & Bottom & 992 & 1170 & 18107 & 4227 & 3605 \\
\hline 39 & Top & 1592 & 1873 & 29224 & 4227 & 3605 \\
\hline 39 & Bottom & 1736 & 2041 & 31924 & 11580 & 9900 \\
\hline 38 & Top & 2213 & 2594 & 40957 & 11580 & 9900 \\
\hline 38 & Bottom & 2325 & 2723 & 43110 & 21617 & 18529 \\
\hline 37 & Top & 2684 & 3133 & 50161 & 21617 & 18529 \\
\hline 37 & Bottom & 2766 & 3225 & 51803 & 33680 & 28962 \\
\hline 36 & Top & 3021 & 3505 & 57038 & 33680 & 28962 \\
\hline 36 & Bottom & 3077 & 3564 & 58222 & 47162 & 40710 \\
\hline 35 & Top & 3243 & 3731 & 61882 & 47162 & 40710 \\
\hline 35 & Bottom & 3277 & 3763 & 62683 & 61522 & 53344 \\
\hline 34 & Top & 3376 & 3844 & 65090 & 61522 & 53344 \\
\hline 34 & Bottom & 3396 & 3856 & 65605 & 76308 & 66513 \\
\hline 33 & Top & 3452 & 3880 & 67157 & 76308 & 66513 \\
\hline 33 & Bottom & 3464 & 3882 & 67502 & 91172 & 79957 \\
\hline 32 & Top & 3507 & 3883 & 68650 & 91172 & 79957 \\
\hline 32 & Bottom & 3519 & 3884 & 68949 & 105886 & 93514 \\
\hline 31 & Top & 3574 & 3897 & 70149 & 105886 & 93514 \\
\hline 31 & Bottom & 3592 & 3905 & 70518 & 120339 & 107122 \\
\hline 30 & Top & 3680 & 3959 & 72158 & 120339 & 107122 \\
\hline 30 & Bottom & 3709 & 3980 & 72684 & 134541 & 120812 \\
\hline 29 & Top & 3840 & 4087 & 75012 & 134541 & 120812 \\
\hline 29 & Bottom & 3880 & 4122 & 75738 & 148598 & 134692 \\
\hline 28 & Top & 4050 & 4280 & 78812 & 148598 & 134692 \\
\hline 28 & Bottom & 4100 & 4328 & 79728 & 162691 & 148921 \\
\hline 27 & Top & 4295 & 4522 & 83422 & 162691 & 148921 \\
\hline 27 & Bottom & 4350 & 4577 & 84474 & 177037 & 163682 \\
\hline
\end{tabular}




\begin{tabular}{|c|c|c|c|c|c|c|}
\hline 26 & Top & 4554 & 4787 & 88530 & 177037 & 163682 \\
\hline 26 & Bottom & 4608 & 4843 & 89637 & 191853 & 179149 \\
\hline 25 & Top & 4804 & 5047 & 93737 & 191853 & 179149 \\
\hline 25 & Bottom & 4854 & 5100 & 94813 & 207322 & 195462 \\
\hline 24 & Top & 5030 & 5283 & 98649 & 207322 & 195462 \\
\hline 24 & Bottom & 5073 & 5328 & 99617 & 223572 & 212706 \\
\hline 23 & Top & 5222 & 5480 & 102938 & 223572 & 212706 \\
\hline 23 & Bottom & 5258 & 5516 & 103742 & 240663 & 230911 \\
\hline 22 & Top & 5377 & 5636 & 106393 & 240663 & 230911 \\
\hline 22 & Bottom & 5406 & 5664 & 107007 & 258596 & 250054 \\
\hline 21 & Top & 5501 & 5755 & 108945 & 258596 & 250054 \\
\hline 21 & Bottom & 5523 & 5776 & 109375 & 277321 & 270071 \\
\hline 20 & Top & 5600 & 5847 & 110682 & 277321 & 270071 \\
\hline 20 & Bottom & 5619 & 5865 & 110964 & 296761 & 290879 \\
\hline 19 & Top & 5685 & 5927 & 111839 & 296761 & 290879 \\
\hline 19 & Bottom & 5702 & 5943 & 112043 & 316827 & 312385 \\
\hline 18 & Top & 5767 & 6004 & 112783 & 316827 & 312385 \\
\hline 18 & Bottom & 5785 & 6020 & 112996 & 337432 & 334501 \\
\hline 17 & Top & 5855 & 6086 & 113945 & 337432 & 334501 \\
\hline 17 & Bottom & 5874 & 6105 & 114259 & 358503 & 357151 \\
\hline 16 & Top & 5952 & 6180 & 115733 & 358503 & 357151 \\
\hline 16 & Bottom & 5973 & 6202 & 116221 & 379891 & 380182 \\
\hline 15 & Top & 6058 & 6289 & 118422 & 379788 & 380072 \\
\hline 15 & Bottom & 6081 & 6314 & 119114 & 401439 & 403423 \\
\hline 14 & Top & 6170 & 6416 & 122045 & 401335 & 403312 \\
\hline 14 & Bottom & 6194 & 6445 & 122911 & 423386 & 427106 \\
\hline 13 & Top & 6284 & 6562 & 126350 & 423386 & 427106 \\
\hline 13 & Bottom & 6309 & 6596 & 127305 & 445721 & 451208 \\
\hline 12 & Top & 6401 & 6730 & 130861 & 445615 & 451094 \\
\hline 12 & Bottom & 6427 & 6768 & 131783 & 468213 & 475449 \\
\hline 11 & Top & 6524 & 6920 & 134969 & 468213 & 475449 \\
\hline 11 & Bottom & 6551 & 6964 & 135730 & 491070 & 500010 \\
\hline
\end{tabular}




\begin{tabular}{|c|c|c|c|c|c|c|}
\hline 10 & Top & 6658 & 7138 & 138134 & 490971 & 499901 \\
\hline 10 & Bottom & 6688 & 7188 & 138645 & 513998 & 524522 \\
\hline 9 & Top & 6810 & 7387 & 140056 & 513904 & 524419 \\
\hline 9 & Bottom & 6845 & 7443 & 140308 & 537194 & 549136 \\
\hline 8 & Top & 6987 & 7661 & 140943 & 537105 & 549038 \\
\hline 8 & Bottom & 7028 & 7721 & 141075 & 560662 & 573804 \\
\hline 7 & Top & 7198 & 7947 & 141830 & 560579 & 573711 \\
\hline 7 & Bottom & 7248 & 8009 & 142198 & 584401 & 598483 \\
\hline 6 & Top & 7459 & 8248 & 144874 & 584324 & 598397 \\
\hline 6 & Bottom & 7523 & 8317 & 146086 & 608399 & 623144 \\
\hline 5 & Top & 7801 & 8618 & 153290 & 608330 & 623067 \\
\hline 5 & Bottom & 7889 & 8715 & 156091 & 632644 & 647774 \\
\hline 4 & Top & 8279 & 9175 & 170431 & 632585 & 647706 \\
\hline 4 & Bottom & 8405 & 9331 & 175404 & 657175 & 672397 \\
\hline 3 & Top & 8975 & 10059 & 198308 & 657126 & 672341 \\
\hline 3 & Bottom & 9159 & 10300 & 205609 & 682162 & 697118 \\
\hline 2 & Top & 9982 & 11399 & 236856 & 682125 & 697077 \\
\hline 2 & Bottom & 10242 & 11756 & 246237 & 708032 & 722170 \\
\hline 1 & Top & 11348 & 13338 & 283759 & 708009 & 722145 \\
\hline 1 & Bottom & 11968 & 14279 & 303342 & 745131 & 756673 \\
\hline
\end{tabular}

\begin{tabular}{|r|l|l|r|r|r|r|}
\hline \multicolumn{7}{|c|}{ WALL FORCES - MODEL 2 } \\
\hline \multicolumn{1}{|c|}{ Location } & \multicolumn{1}{|c|}{ P } & V2 & T & \multicolumn{1}{c|}{ M3 } \\
\hline 40 & W17 & Top & 137 & 122 & 9 & 304 \\
\hline 40 & W17 & Bottom & 137 & 119 & 12 & 104 \\
\hline 39 & W17 & Top & 179 & 92 & 9 & 223 \\
\hline 39 & W17 & Bottom & 199 & 90 & 10 & 101 \\
\hline 38 & W17 & Top & 255 & 90 & 9 & 235 \\
\hline 38 & W17 & Bottom & 285 & 89 & 10 & 122 \\
\hline 37 & W17 & Top & 344 & 93 & 9 & 259 \\
\hline 37 & W17 & Bottom & 379 & 92 & 10 & 152 \\
\hline
\end{tabular}




\begin{tabular}{|c|c|c|c|c|c|c|}
\hline 36 & W17 & Top & 436 & 96 & 9 & 284 \\
\hline 36 & W17 & Bottom & 470 & 95 & 10 & 181 \\
\hline 35 & W17 & Top & 522 & 99 & 9 & 309 \\
\hline 35 & W17 & Bottom & 555 & 98 & 10 & 205 \\
\hline 34 & W17 & Top & 600 & 102 & 9 & 331 \\
\hline 34 & W17 & Bottom & 628 & 101 & 10 & 225 \\
\hline 33 & W17 & Top & 666 & 106 & 9 & 350 \\
\hline 33 & W17 & Bottom & 690 & 105 & 10 & 240 \\
\hline 32 & W17 & Top & 721 & 110 & 9 & 365 \\
\hline 32 & W17 & Bottom & 740 & 109 & 10 & 252 \\
\hline 31 & W17 & Top & 765 & 114 & 9 & 376 \\
\hline 31 & W17 & Bottom & 781 & 113 & 11 & 262 \\
\hline 30 & W17 & Top & 800 & 118 & 9 & 382 \\
\hline 30 & W17 & Bottom & 813 & 117 & 11 & 270 \\
\hline 29 & W17 & Top & 828 & 123 & 9 & 385 \\
\hline 29 & W17 & Bottom & 840 & 121 & 11 & 277 \\
\hline 28 & W17 & Top & 851 & 127 & 9 & 384 \\
\hline 28 & W17 & Bottom & 864 & 125 & 11 & 285 \\
\hline 27 & W17 & Top & 874 & 131 & 9 & 379 \\
\hline 27 & W17 & Bottom & 889 & 129 & 11 & 295 \\
\hline 26 & W17 & Top & 898 & 135 & 9 & 372 \\
\hline 26 & W17 & Bottom & 918 & 133 & 11 & 306 \\
\hline 25 & W17 & Top & 927 & 139 & 9 & 362 \\
\hline 25 & W17 & Bottom & 951 & 137 & 11 & 319 \\
\hline 24 & W17 & Top & 962 & 142 & 9 & 350 \\
\hline 24 & W17 & Bottom & 992 & 140 & 11 & 336 \\
\hline 23 & W17 & Top & 1006 & 145 & 9 & 336 \\
\hline 23 & W17 & Bottom & 1041 & 143 & 11 & 356 \\
\hline 22 & W17 & Top & 1058 & 148 & 9 & 321 \\
\hline 22 & W17 & Bottom & 1099 & 146 & 11 & 379 \\
\hline 21 & W17 & Top & 1120 & 151 & 9 & 305 \\
\hline 21 & W17 & Bottom & 1167 & 149 & 11 & 405 \\
\hline
\end{tabular}




\begin{tabular}{|c|c|c|c|c|c|c|}
\hline 20 & W17 & Top & 1191 & 153 & 9 & 289 \\
\hline 20 & W17 & Bottom & 1243 & 152 & 11 & 434 \\
\hline 19 & W17 & Top & 1271 & 155 & 9 & 275 \\
\hline 19 & W17 & Bottom & 1328 & 154 & 12 & 466 \\
\hline 18 & W17 & Top & 1360 & 156 & 9 & 264 \\
\hline 18 & W17 & Bottom & 1421 & 155 & 12 & 500 \\
\hline 17 & W17 & Top & 1457 & 157 & 9 & 258 \\
\hline 17 & W17 & Bottom & 1523 & 157 & 12 & 537 \\
\hline 16 & W17 & Top & 1563 & 158 & 9 & 259 \\
\hline 16 & W17 & Bottom & 1633 & 158 & 12 & 575 \\
\hline 15 & W17 & Top & 1677 & 158 & 9 & 269 \\
\hline 15 & W17 & Bottom & 1751 & 159 & 12 & 616 \\
\hline 14 & W17 & Top & 1798 & 158 & 9 & 287 \\
\hline 14 & W17 & Bottom & 1875 & 159 & 12 & 658 \\
\hline 13 & W17 & Top & 1927 & 157 & 9 & 315 \\
\hline 13 & W17 & Bottom & 2007 & 159 & 13 & 701 \\
\hline 12 & W17 & Top & 2062 & 156 & 10 & 351 \\
\hline 12 & W17 & Bottom & 2146 & 159 & 13 & 746 \\
\hline 11 & W17 & Top & 2205 & 155 & 10 & 394 \\
\hline 11 & W17 & Bottom & 2292 & 158 & 13 & 793 \\
\hline 10 & W17 & Top & 2355 & 153 & 10 & 444 \\
\hline 10 & W17 & Bottom & 2445 & 157 & 13 & 841 \\
\hline 9 & W17 & Top & 2513 & 152 & 10 & 500 \\
\hline 9 & W17 & Bottom & 2605 & 157 & 13 & 890 \\
\hline 8 & W17 & Top & 2678 & 150 & 10 & 561 \\
\hline 8 & W17 & Bottom & 2774 & 156 & 14 & 941 \\
\hline 7 & W17 & Top & 2852 & 148 & 11 & 627 \\
\hline 7 & W17 & Bottom & 2951 & 156 & 14 & 993 \\
\hline 6 & W17 & Top & 3035 & 147 & 11 & 699 \\
\hline 6 & W17 & Bottom & 3139 & 156 & 14 & 1049 \\
\hline 5 & W17 & Top & 3230 & 146 & 11 & 777 \\
\hline 5 & W17 & Bottom & 3339 & 157 & 15 & 1107 \\
\hline
\end{tabular}




\begin{tabular}{|c|c|c|c|c|c|c|}
\hline 4 & W17 & Top & 3437 & 145 & 12 & 862 \\
\hline 4 & W17 & Bottom & 3550 & 158 & 15 & 1171 \\
\hline 3 & W17 & Top & 3654 & 143 & 12 & 954 \\
\hline 3 & W17 & Bottom & 3771 & 158 & 16 & 1242 \\
\hline 2 & W17 & Top & 3879 & 139 & 14 & 1059 \\
\hline 2 & W17 & Bottom & 3993 & 153 & 16 & 1325 \\
\hline 1 & W17 & Top & 4073 & 135 & 12 & 1177 \\
\hline \multirow[t]{2}{*}{1} & W17 & Bottom & 4229 & 151 & 8 & 1561 \\
\hline & & & $\mathbf{k N}$ & $\mathbf{k N}$ & kN-m & $\mathrm{kN}-\mathrm{m}$ \\
\hline \multicolumn{7}{|c|}{ TABLE: WALL FORCES - MODEL 4} \\
\hline Story & Pier & Location & $\mathbf{P}$ & $\mathbf{V 2}$ & $\mathbf{T}$ & M3 \\
\hline 40 & W17 & Top & 394 & 349 & 27 & 872 \\
\hline 40 & W17 & Bottom & 391 & 338 & 34 & 288 \\
\hline 39 & W17 & Top & 501 & 253 & 26 & 639 \\
\hline 39 & W17 & Bottom & 538 & 246 & 28 & 237 \\
\hline 38 & W17 & Top & 675 & 244 & 26 & 673 \\
\hline 38 & W17 & Bottom & 730 & 241 & 29 & 241 \\
\hline 37 & W17 & Top & 873 & 254 & 26 & 732 \\
\hline 37 & W17 & Bottom & 937 & 253 & 29 & 296 \\
\hline 36 & W17 & Top & 1,080 & 266 & 26 & 788 \\
\hline 36 & W17 & Bottom & 1,152 & 265 & 30 & 372 \\
\hline 35 & W17 & Top & 1,294 & 279 & 25 & 844 \\
\hline 35 & W17 & Bottom & 1,372 & 276 & 30 & 454 \\
\hline 34 & W17 & Top & 1,508 & 290 & 25 & 897 \\
\hline 34 & W17 & Bottom & 1,588 & 287 & 30 & 533 \\
\hline 33 & W17 & Top & 1,715 & 301 & 25 & 946 \\
\hline 33 & W17 & Bottom & 1,793 & 297 & 30 & 605 \\
\hline 32 & W17 & Top & 1,905 & 311 & 26 & 990 \\
\hline 32 & W17 & Bottom & 1,977 & 307 & 30 & 667 \\
\hline 31 & W17 & Top & 2,073 & 321 & 26 & 1,026 \\
\hline 31 & W17 & Bottom & 2,136 & 316 & 30 & 716 \\
\hline 30 & W17 & Top & 2,214 & 331 & 26 & 1,053 \\
\hline
\end{tabular}




\begin{tabular}{|c|c|c|c|c|c|c|}
\hline 30 & W17 & Bottom & 2,268 & 326 & 30 & 754 \\
\hline 29 & W17 & Top & 2,326 & 342 & 26 & 1,069 \\
\hline 29 & W17 & Bottom & 2,372 & 336 & 31 & 782 \\
\hline 28 & W17 & Top & 2,414 & 354 & 26 & 1,074 \\
\hline 28 & W17 & Bottom & 2,456 & 348 & 31 & 803 \\
\hline 27 & W17 & Top & 2,485 & 366 & 26 & 1,067 \\
\hline 27 & W17 & Bottom & 2,529 & 360 & 31 & 823 \\
\hline 26 & W17 & Top & 2,550 & 379 & 26 & 1,049 \\
\hline 26 & W17 & Bottom & 2,600 & 373 & 31 & 846 \\
\hline 25 & W17 & Top & 2,620 & 391 & 26 & 1,021 \\
\hline 25 & W17 & Bottom & 2,684 & 385 & 31 & 878 \\
\hline 24 & W17 & Top & 2,708 & 403 & 26 & 983 \\
\hline 24 & W17 & Bottom & 2,788 & 398 & 31 & 922 \\
\hline 23 & W17 & Top & 2,821 & 414 & 26 & 938 \\
\hline 23 & W17 & Bottom & 2,920 & 409 & 32 & 981 \\
\hline 22 & W17 & Top & 2,965 & 423 & 26 & 889 \\
\hline 22 & W17 & Bottom & 3,084 & 418 & 32 & 1,052 \\
\hline 21 & W17 & Top & 3,143 & 430 & 26 & 837 \\
\hline 21 & W17 & Bottom & 3,281 & 426 & 32 & 1,136 \\
\hline 20 & W17 & Top & 3,354 & 436 & 26 & 788 \\
\hline 20 & W17 & Bottom & 3,510 & 433 & 33 & 1,228 \\
\hline 19 & W17 & Top & 3,596 & 440 & 26 & 745 \\
\hline 19 & W17 & Bottom & 3,768 & 437 & 33 & 1,326 \\
\hline 18 & W17 & Top & 3,865 & 442 & 26 & 714 \\
\hline 18 & W17 & Bottom & 4,050 & 440 & 33 & 1,428 \\
\hline 17 & W17 & Top & 4,157 & 442 & 26 & 701 \\
\hline 17 & W17 & Bottom & 4,353 & 441 & 34 & 1,541 \\
\hline 16 & W17 & Top & 4,469 & 456 & 24 & 715 \\
\hline 16 & W17 & Bottom & 4,689 & 456 & 27 & 1,649 \\
\hline 15 & W17 & Top & 4,814 & 447 & 23 & 748 \\
\hline 15 & W17 & Bottom & 5,026 & 447 & 27 & 1,755 \\
\hline 14 & W17 & Top & 5,159 & 438 & 24 & 808 \\
\hline
\end{tabular}




\begin{tabular}{|c|c|c|c|c|c|c|}
\hline 14 & W17 & Bottom & 5,362 & 440 & 35 & 1,891 \\
\hline 13 & W17 & Top & 5,503 & 462 & 24 & 905 \\
\hline 13 & W17 & Bottom & 5,747 & 465 & 26 & 1,984 \\
\hline 12 & W17 & Top & 5,899 & 441 & 23 & 983 \\
\hline 12 & W17 & Bottom & 6,119 & 445 & 36 & 2,147 \\
\hline 11 & W17 & Top & 6,284 & 462 & 24 & 1,142 \\
\hline 11 & W17 & Bottom & 6,554 & 469 & 25 & 2,260 \\
\hline 10 & W17 & Top & 6,733 & 449 & 18 & 1,262 \\
\hline 10 & W17 & Bottom & 6,995 & 454 & 24 & 2,411 \\
\hline 9 & W17 & Top & 7,188 & 443 & 17 & 1,435 \\
\hline 9 & W17 & Bottom & 7,458 & 449 & 24 & 2,556 \\
\hline 8 & W17 & Top & 7,666 & 435 & 16 & 1,609 \\
\hline 8 & W17 & Bottom & 7,947 & 442 & 23 & 2,704 \\
\hline 7 & W17 & Top & 8,172 & 426 & 15 & 1,800 \\
\hline 7 & W17 & Bottom & 8,463 & 435 & 22 & 2,856 \\
\hline 6 & W17 & Top & 8,704 & 421 & 14 & 2,009 \\
\hline 6 & W17 & Bottom & 9,005 & 433 & 21 & 3,013 \\
\hline 5 & W17 & Top & 9,262 & 426 & 14 & 2,237 \\
\hline 5 & W17 & Bottom & 9,572 & 441 & 21 & 3,180 \\
\hline 4 & W17 & Top & 9,846 & 448 & 15 & 2,484 \\
\hline 4 & W17 & Bottom & 10,166 & 468 & 21 & 3,361 \\
\hline 3 & W17 & Top & 10,458 & 490 & 16 & 2,750 \\
\hline 3 & W17 & Bottom & 10,787 & 515 & 21 & 3,571 \\
\hline 2 & W17 & Top & 11,092 & 535 & 18 & 3,044 \\
\hline 2 & W17 & Bottom & 11,417 & 562 & 21 & 3,813 \\
\hline 1 & W17 & Top & 11,674 & 561 & 25 & 3,362 \\
\hline 1 & W17 & Bottom & 12,167 & 622 & 24 & 4,542 \\
\hline & & & $\mathbf{k N}$ & $\mathbf{k N}$ & kN-m & kN-m \\
\hline
\end{tabular}


Part III Concrete Moment Frame- Low - Rise (Ductile /Conventional Framing)

\begin{tabular}{|r|r|r|}
\hline \multicolumn{3}{|c|}{ STORY DRIFTS } \\
\hline & MODEL 5 & MODEL 7 \\
\hline Story & Drift(m) & \multicolumn{1}{c|}{ Drift(m) } \\
\hline 12 & 0.000152 & 0.000532 \\
\hline 11 & 0.000233 & 0.000813 \\
\hline 10 & 0.000295 & 0.00103 \\
\hline 9 & 0.000342 & 0.001195 \\
\hline 8 & 0.000378 & 0.001322 \\
\hline 7 & 0.000408 & 0.001425 \\
\hline 6 & 0.000433 & 0.001512 \\
\hline 5 & 0.000456 & 0.001591 \\
\hline 4 & 0.000478 & 0.001668 \\
\hline 3 & 0.0005 & 0.001747 \\
\hline 2 & 0.00054 & 0.001885 \\
\hline 1 & 0.000762 & 0.002661 \\
\hline
\end{tabular}

\begin{tabular}{|c|c|c|c|c|c|c|}
\hline \multicolumn{7}{|c|}{ BASE REACTIONS - MODEL 5} \\
\hline \multirow[t]{2}{*}{ Load Case/Combo } & FX & FY & FZ & MX & MY & MZ \\
\hline & $\mathrm{kN}$ & $\mathrm{kN}$ & $\mathrm{kN}$ & $\mathrm{kN}-\mathrm{m}$ & $\mathrm{kN}-\mathrm{m}$ & $\mathrm{kN}-\mathrm{m}$ \\
\hline SPECX1 Max & 1909 & 1847 & 0 & 51809 & 53805 & 38157 \\
\hline \multicolumn{7}{|c|}{ BASE REACTIONS - MODEL 7} \\
\hline \multirow[t]{2}{*}{ Load Case/Combo } & $\mathbf{F X}$ & FY & FZ & MX & MY & MZ \\
\hline & $\mathrm{kN}$ & $\mathrm{kN}$ & $\mathrm{kN}$ & $\mathrm{kN}-\mathrm{m}$ & $\mathrm{kN}-\mathrm{m}$ & $\mathrm{kN}-\mathrm{m}$ \\
\hline SPECX1 Max & 6667 & 6452 & 0 & 180970 & 187942 & 133285 \\
\hline
\end{tabular}




\begin{tabular}{|c|c|c|c|c|c|c|c|c|c|}
\hline \multicolumn{10}{|c|}{ STORY FORCES - MODEL 5} \\
\hline \multirow[t]{2}{*}{ Story } & \multicolumn{2}{|c|}{ Location } & $\mathbf{V X}$ & VY & \multicolumn{2}{|c|}{$\mathbf{T}$} & \multicolumn{2}{|c|}{ MX } & MY \\
\hline & & & $\mathrm{kN}$ & $\mathrm{kN}$ & $\mathrm{kN}$ & $-m$ & $\mathrm{kN}$ & $\mathrm{J}-\mathrm{m}$ & $\mathrm{kN}-\mathrm{m}$ \\
\hline 1 & \multicolumn{2}{|l|}{ Top } & 387 & 383 & & 7837 & & 0 & 0 \\
\hline 1 & \multicolumn{2}{|l|}{ Bottom } & 387 & 383 & & 7837 & & 1404 & 1418 \\
\hline 1 & \multicolumn{2}{|l|}{ Top } & 680 & 670 & & 13732 & & 1404 & 1418 \\
\hline 1 & \multicolumn{2}{|l|}{ Bottom } & 680 & 670 & & 13732 & & 3856 & 3906 \\
\hline 1 & \multicolumn{2}{|l|}{ Top } & 896 & 878 & & 18045 & & 3856 & 3906 \\
\hline 1 & \multicolumn{2}{|l|}{ Bottom } & 896 & 878 & & 18045 & & 7041 & 7155 \\
\hline & \multicolumn{2}{|l|}{ Top } & 1058 & 1032 & & 21250 & & 7041 & 7155 \\
\hline & \multicolumn{2}{|l|}{ Bottom } & 1058 & 1032 & & 21250 & & 10730 & 10938 \\
\hline & \multicolumn{2}{|l|}{ Top } & 1185 & 1151 & & 23751 & & 10730 & 10938 \\
\hline & \multicolumn{2}{|l|}{ Bottom } & 1185 & 1151 & & 23751 & & 14775 & 15108 \\
\hline & \multicolumn{2}{|l|}{ Top } & 1291 & 1250 & & 25838 & & 14775 & 15108 \\
\hline & \multicolumn{2}{|l|}{ Bottom } & 1291 & 1250 & & 25838 & & 19083 & 19573 \\
\hline & \multicolumn{2}{|l|}{ Top } & 1387 & 1339 & & 27717 & & 19083 & 19573 \\
\hline & \multicolumn{2}{|l|}{ Bottom } & 1387 & 1339 & & 27717 & & 23609 & 24285 \\
\hline & \multicolumn{2}{|l|}{ Top } & 1479 & 1425 & & 29532 & & 23609 & 24285 \\
\hline & \multicolumn{2}{|l|}{ Bottom } & 1479 & 1425 & & 29532 & & 28336 & 29226 \\
\hline & \multicolumn{2}{|l|}{ Top } & 1573 & 1514 & & 31393 & & 28336 & 29226 \\
\hline & \multicolumn{2}{|l|}{ Bottom } & 1573 & 1514 & & 31393 & & 33275 & 34401 \\
\hline & \multicolumn{2}{|l|}{ Top } & 1671 & 1610 & & 33366 & & 33275 & 34401 \\
\hline & \multicolumn{2}{|l|}{ Bottom } & 1671 & 1610 & & 33366 & & 38456 & 39835 \\
\hline & \multicolumn{2}{|l|}{ Top } & 1775 & 1713 & & 35470 & & 38456 & 39835 \\
\hline & Bottom & & 1775 & 1713 & & 35470 & & 43927 & 45568 \\
\hline & Top & & 1878 & 1816 & & 37564 & & 43927 & 45568 \\
\hline & Bottom & & 1878 & 1816 & & 37564 & & 51809 & 53805 \\
\hline & & STO & DRY FO & $\overline{C E S}$ - MC & ODEL 7 & & & & \\
\hline Story & Location & VX & VY & $T$ & & & & & MY \\
\hline & & $\mathrm{kN}$ & $\mathrm{kN}$ & $\mathrm{kN}$ & & $\mathrm{kN}$ & & & $\mathrm{kN}-\mathrm{m}$ \\
\hline 12 & Top & 1351 & 13 & & 7373.7 & & 0 & & 0 \\
\hline 12 & Bottom & 1351 & 13 & & 7373.7 & & 903.3 & & 4952.76 \\
\hline 11 & Top & 2375 & 23 & & 7968.2 & & 4903.3 & & 4952.76 \\
\hline
\end{tabular}




\begin{tabular}{|c|c|c|c|c|c|c|}
\hline 11 & Bottom & 2375 & 2340 & 47968.2 & 13469 & 13644 \\
\hline 10 & Top & 3129 & 3068 & 63033.1 & 13469 & 13644 \\
\hline 10 & Bottom & 3129 & 3068 & 63033.1 & 24594 & 24991.3 \\
\hline 9 & Top & 3694 & 3605 & 74227.3 & 24593 & 24991.3 \\
\hline 9 & Bottom & 3694 & 3605 & 74227.3 & 37481 & 38207.2 \\
\hline 8 & Top & 4138 & 4021 & 82963.5 & 37481 & 38207.2 \\
\hline 8 & Bottom & 4138 & 4021 & 82963.5 & 51609 & 52773 \\
\hline 7 & Top & 4510 & 4366 & 90254.3 & 51609 & 52773 \\
\hline 7 & Bottom & 4510 & 4366 & 90254.3 & 66660 & 68370.8 \\
\hline 6 & Top & 4845 & 4676 & 96816.5 & 66660 & 68370.7 \\
\hline 6 & Bottom & 4845 & 4676 & 96816.5 & 82466 & 84830 \\
\hline 5 & Top & 5167 & 4978 & 103160 & 82466 & 84829.9 \\
\hline 5 & Bottom & 5167 & 4978 & 103160 & 98978 & 102089 \\
\hline 4 & Top & 5494 & 5290 & 109657 & 98978 & 102089 \\
\hline 4 & Bottom & 5494 & 5290 & 109657 & 116230 & 120166 \\
\hline 3 & Top & 5838 & 5625 & 116549 & 116230 & 120166 \\
\hline 3 & Bottom & 5838 & 5625 & 116549 & 134328 & 139146 \\
\hline 2 & Top & 6202 & 5984 & 123900 & 134328 & 139146 \\
\hline 2 & Bottom & 6202 & 5984 & 123900 & 153441 & 159173 \\
\hline 1 & Top & 6561 & 6343 & 131213 & 153440 & 159173 \\
\hline 1 & Bottom & 6561 & 6343 & 131213 & 180970 & 187942 \\
\hline
\end{tabular}

\begin{tabular}{|r|l|r|r|r|r|}
\hline \multicolumn{7}{|c|}{ BEAM FORCES - MODEL 5 } \\
\hline \multicolumn{1}{|c|}{ Beam } & P (kN) & \multicolumn{1}{|c|}{ V2 (kN) } & T(kN-m) & M3(kN-m) \\
\hline 12 & B11 & 0.00 & 3.12 & 0.14 & 8.5 \\
\hline 11 & B11 & 0.00 & 8.93 & 0.39 & 29.3 \\
\hline 10 & B11 & 1.05 & 14.87 & 0.65 & 38.6 \\
\hline 9 & B11 & 1.01 & 19.26 & 0.84 & 46.0 \\
\hline 8 & B11 & 1.03 & 22.74 & 0.99 & 52.5 \\
\hline 7 & B11 & 1.07 & 25.70 & 1.12 & 58.6 \\
\hline 6 & B11 & 1.11 & 28.46 & 1.25 & 65.1 \\
\hline 5 & B11 & 1.15 & 31.28 & 1.50 & 72.2 \\
\hline 4 & B11 & & 34.32 & & \\
\hline
\end{tabular}




\begin{tabular}{|r|l|r|r|r|r|}
\hline 3 & B11 & 1.21 & 37.74 & 1.64 & 80.2 \\
\hline 2 & B11 & 1.49 & 41.85 & 1.80 & 90.5 \\
\hline 1 & B11 & 5.03 & 53.54 & 2.32 & 114.3 \\
\hline
\end{tabular}

\begin{tabular}{|r|l|r|r|r|r|}
\hline \multicolumn{7}{|c|}{ BEAM FORCES - MODEL 7 } \\
\hline Story & \multicolumn{1}{|c|}{ Beam } & P (kN) & V2 (kN) & T(kN-m) & M3(kN-m) \\
\hline 12 & B11 & 0.00 & 10.892 & 0.50 & 29.6 \\
\hline 11 & B11 & 0.00 & 31.202 & 1.35 & 102.4 \\
\hline 10 & B11 & 3.66 & 51.931 & 2.25 & 134.8 \\
\hline 9 & B11 & 3.54 & 67.285 & 2.93 & 160.8 \\
\hline 8 & B11 & 3.61 & 79.435 & 3.47 & 183.3 \\
\hline 7 & B11 & 3.74 & 89.766 & 4.93 & 204.9 \\
\hline 6 & B11 & 3.88 & 99.428 & 4.78 & 227.3 \\
\hline 5 & B11 & 4.02 & 109.25 & 5.23 & 252.0 \\
\hline 4 & B11 & 4.16 & 119.87 & 5.73 & 280.1 \\
\hline 3 & B11 & 4.23 & 131.82 & 6.29 & 316.0 \\
\hline 2 & B11 & 5.20 & 146.18 & 8.09 & 399.2 \\
\hline 1 & B11 & 17.57 & 187.01 & & \\
\hline
\end{tabular}


Part IV Concrete Moment Frame- High - Rise (Ductile /Conventional Framing)

\begin{tabular}{|c|c|c|c|c|c|}
\hline \multicolumn{6}{|c|}{ STORY DRIFTS } \\
\hline & MODEL 6 & MODEL 8 & & MODEL 6 & MODEL 8 \\
\hline Story & Drift & Drift & Story & Drift & Drift \\
\hline 40 & 0.000558 & 0.001949 & 20 & 0.001008 & 0.003522 \\
\hline 39 & 0.000593 & 0.002073 & 19 & 0.001015 & 0.003544 \\
\hline 38 & 0.00063 & 0.002202 & 18 & 0.001019 & 0.003561 \\
\hline 37 & 0.000666 & 0.002325 & 17 & 0.001023 & 0.003572 \\
\hline 36 & 0.000698 & 0.00244 & 16 & 0.001024 & 0.003577 \\
\hline 35 & 0.000729 & 0.002547 & 15 & 0.001024 & 0.003575 \\
\hline 34 & 0.000758 & 0.002649 & 14 & 0.001021 & 0.003567 \\
\hline 33 & 0.000786 & 0.002744 & 13 & 0.001017 & 0.003553 \\
\hline 32 & 0.000812 & 0.002835 & 12 & 0.001011 & 0.003532 \\
\hline 31 & 0.000836 & 0.00292 & 11 & 0.001003 & 0.003504 \\
\hline 30 & 0.000859 & 0.003 & 10 & 0.000993 & 0.003468 \\
\hline 29 & 0.00088 & 0.003075 & 9 & 0.000981 & 0.003426 \\
\hline 28 & 0.0009 & 0.003145 & 8 & 0.000966 & 0.003375 \\
\hline 27 & 0.000919 & 0.003211 & 7 & 0.000949 & 0.003316 \\
\hline 26 & 0.000936 & 0.003271 & 6 & 0.00093 & 0.003249 \\
\hline 25 & 0.000952 & 0.003326 & 5 & 0.000909 & 0.003175 \\
\hline 24 & 0.000966 & 0.003376 & 4 & 0.000885 & 0.003091 \\
\hline 23 & 0.000979 & 0.00342 & 3 & 0.000861 & 0.003006 \\
\hline 22 & 0.00099 & 0.003459 & 2 & 0.000864 & 0.003017 \\
\hline 21 & 0.001 & 0.003493 & 1 & 0.00117 & 0.004086 \\
\hline
\end{tabular}




\begin{tabular}{|c|c|c|c|c|c|c|}
\hline \multicolumn{7}{|c|}{ BASE REACTIONS - MODEL 6} \\
\hline \multirow[t]{2}{*}{ Load Case/Combo } & FX & FY & FZ & MX & MY & MZ \\
\hline & $\mathrm{kN}$ & $\mathrm{kN}$ & $\mathrm{kN}$ & $\mathrm{kN}-\mathrm{m}$ & $\mathrm{kN}-\mathrm{m}$ & $\mathrm{kN}-\mathrm{m}$ \\
\hline SPECX1 Max & 3185 & 3051 & 0 & 250786 & 249074 & 63518 \\
\hline \multicolumn{7}{|c|}{ BASE REACTIONS - MODEL 8} \\
\hline \multirow[t]{2}{*}{ Load Case/Combo } & FX & FY & FZ & MX & MY & MZ \\
\hline & $\mathrm{kN}$ & $\mathrm{kN}$ & $\mathrm{kN}$ & $\mathrm{kN}-\mathrm{m}$ & $\mathrm{kN}-\mathrm{m}$ & $\mathrm{kN}-\mathrm{m}$ \\
\hline SPECX1 Max & 11126 & 10656 & 0 & 876010 & 870031 & 221880 \\
\hline
\end{tabular}

\begin{tabular}{|c|c|c|c|c|c|c|}
\hline \multicolumn{7}{|c|}{ STORY FORCES - MODEL 6} \\
\hline Story & Location & $\mathbf{V X}$ & $\mathbf{V Y}$ & $\mathbf{T}$ & MX & MY \\
\hline & & $\mathrm{kN}$ & $\mathrm{kN}$ & $\mathrm{kN}-\mathrm{m}$ & $\mathrm{kN}-\mathrm{m}$ & $\mathrm{kN}-\mathrm{m}$ \\
\hline 40 & Top & 189 & 190 & 3829 & 0 & 0 \\
\hline 40 & Bottom & 189 & 190 & 3829 & 709 & 708 \\
\hline 39 & Top & 356 & 355 & 7184 & 708 & 706 \\
\hline 39 & Bottom & 356 & 355 & 7184 & 2044 & 2041 \\
\hline 38 & Top & 500 & 498 & 10082 & 2044 & 2042 \\
\hline 38 & Bottom & 500 & 498 & 10082 & 3927 & 3927 \\
\hline 37 & Top & 620 & 617 & 12505 & 3927 & 3926 \\
\hline 37 & Bottom & 620 & 617 & 12505 & 6267 & 6274 \\
\hline 36 & Top & 721 & 717 & 14530 & 6267 & 6274 \\
\hline 36 & Bottom & 721 & 717 & 14530 & 8988 & 9006 \\
\hline 35 & Top & 809 & 804 & 16289 & 8988 & 9006 \\
\hline 35 & Bottom & 809 & 804 & 16289 & 12031 & 12062 \\
\hline 34 & Top & 890 & 885 & 17905 & 12031 & 12062 \\
\hline 34 & Bottom & 890 & 885 & 17905 & 15364 & 15405 \\
\hline 33 & Top & 966 & 962 & 19447 & 15364 & 15405 \\
\hline 33 & Bottom & 966 & 962 & 19447 & 18969 & 19016 \\
\hline 32 & Top & 1040 & 1036 & 20930 & 18969 & 19016 \\
\hline 32 & Bottom & 1040 & 1036 & 20930 & 22839 & 22887 \\
\hline 31 & Top & 1111 & 1106 & 22345 & 22839 & 22887 \\
\hline 31 & Bottom & 1111 & 1106 & 22345 & 26971 & 27014 \\
\hline
\end{tabular}




\begin{tabular}{|c|c|c|c|c|c|c|}
\hline 30 & Top & 1178 & 1173 & 23695 & 26971 & 27014 \\
\hline 30 & Bottom & 1178 & 1173 & 23695 & 31358 & 31394 \\
\hline 29 & Top & 1242 & 1238 & 24999 & 31358 & 31394 \\
\hline 29 & Bottom & 1242 & 1238 & 24999 & 35999 & 36023 \\
\hline 28 & Top & 1306 & 1302 & 26274 & 35999 & 36022 \\
\hline 28 & Bottom & 1306 & 1302 & 26274 & 40891 & 40897 \\
\hline 27 & Top & 1368 & 1364 & 27519 & 40891 & 40897 \\
\hline 27 & Bottom & 1368 & 1364 & 27519 & 46032 & 46016 \\
\hline 26 & Top & 1427 & 1423 & 28718 & 46032 & 46016 \\
\hline 26 & Bottom & 1427 & 1423 & 28718 & 51419 & 51377 \\
\hline 25 & Top & 1484 & 1480 & 29862 & 51419 & 51377 \\
\hline 25 & Bottom & 1484 & 1480 & 29862 & 57047 & 56975 \\
\hline 24 & Top & 1539 & 1535 & 30960 & 57047 & 56975 \\
\hline 24 & Bottom & 1539 & 1535 & 30960 & 62911 & 62805 \\
\hline 23 & Top & 1592 & 1588 & 32031 & 62911 & 62805 \\
\hline 23 & Bottom & 1592 & 1588 & 32031 & 69005 & 68859 \\
\hline 22 & Top & 1644 & 1641 & 33082 & 69005 & 68859 \\
\hline 22 & Bottom & 1644 & 1641 & 33082 & 75323 & 75132 \\
\hline 21 & Top & 1694 & 1692 & 34103 & 75323 & 75132 \\
\hline 21 & Bottom & 1694 & 1692 & 34103 & 81862 & 81620 \\
\hline 20 & Top & 1743 & 1740 & 35079 & 81862 & 81620 \\
\hline 20 & Bottom & 1743 & 1740 & 35079 & 88614 & 88316 \\
\hline 19 & Top & 1789 & 1787 & 36014 & 88614 & 88316 \\
\hline 19 & Bottom & 1789 & 1787 & 36014 & 95574 & 95215 \\
\hline 18 & Top & 1834 & 1832 & 36923 & 95574 & 95215 \\
\hline 18 & Bottom & 1834 & 1832 & 36923 & 102735 & 102309 \\
\hline 17 & Top & 1879 & 1877 & 37814 & 102735 & 102309 \\
\hline 17 & Bottom & 1879 & 1877 & 37814 & 110089 & 109592 \\
\hline 16 & Top & 1921 & 1919 & 38674 & 110089 & 109592 \\
\hline 16 & Bottom & 1921 & 1919 & 38674 & 117631 & 117058 \\
\hline 15 & Top & 1962 & 1959 & 39489 & 117631 & 117057 \\
\hline 15 & Bottom & 1962 & 1959 & 39489 & 125350 & 124698 \\
\hline 14 & Top & 2001 & 1998 & 40270 & 125350 & 124698 \\
\hline 14 & Bottom & 2001 & 1998 & 40270 & 133239 & 132505 \\
\hline
\end{tabular}




\begin{tabular}{|c|c|c|c|c|c|c|}
\hline 13 & Top & 2039 & 2037 & 41042 & 133239 & 132504 \\
\hline 13 & Bottom & 2039 & 2037 & 41042 & 141289 & 140470 \\
\hline 12 & Top & 2077 & 2074 & 41798 & 141289 & 140470 \\
\hline 12 & Bottom & 2077 & 2074 & 41798 & 149492 & 148586 \\
\hline 11 & Top & 2113 & 2108 & 42510 & 149492 & 148586 \\
\hline 11 & Bottom & 2113 & 2108 & 42510 & 157840 & 156846 \\
\hline 10 & Top & 2146 & 2142 & 43181 & 157840 & 156846 \\
\hline 10 & Bottom & 2146 & 2142 & 43181 & 166321 & 165240 \\
\hline 9 & Top & 2179 & 2175 & 43845 & 166321 & 165240 \\
\hline 9 & Bottom & 2179 & 2175 & 43845 & 174927 & 173760 \\
\hline 8 & Top & 2211 & 2206 & 44486 & 174927 & 173760 \\
\hline 8 & Bottom & 2211 & 2206 & 44486 & 183648 & 182396 \\
\hline 7 & Top & 2240 & 2234 & 45067 & 183648 & 182396 \\
\hline 7 & Bottom & 2240 & 2234 & 45067 & 192471 & 191139 \\
\hline 6 & Top & 2269 & 2264 & 45647 & 192471 & 191139 \\
\hline 6 & Bottom & 2269 & 2264 & 45647 & 201386 & 199976 \\
\hline 5 & Top & 2299 & 2292 & 46243 & 201386 & 199976 \\
\hline 5 & Bottom & 2299 & 2292 & 46243 & 210382 & 208899 \\
\hline 4 & Top & 2326 & 2319 & 46787 & 210381 & 208899 \\
\hline 4 & Bottom & 2326 & 2319 & 46787 & 219446 & 217897 \\
\hline 3 & Top & 2356 & 2350 & 47407 & 219445 & 217897 \\
\hline 3 & Bottom & 2356 & 2350 & 47407 & 228569 & 226962 \\
\hline 2 & Top & 2384 & 2377 & 47974 & 228569 & 226962 \\
\hline 2 & Bottom & 2384 & 2377 & 47974 & 237788 & 236128 \\
\hline 1 & Top & 2418 & 2410 & 48670 & 237788 & 236128 \\
\hline 1 & Bottom & 2418 & 2410 & 48670 & 250786 & 249074 \\
\hline
\end{tabular}

\begin{tabular}{|r|l|r|r|r|r|r|}
\hline \multicolumn{7}{|c|}{ STORY FORCES - MODEL 8 } \\
\hline \multicolumn{1}{|c|}{ Story } & \multicolumn{1}{|c|}{ Location } & \multicolumn{1}{c|}{ VX } & \multicolumn{1}{c|}{ VY } & \multicolumn{1}{c|}{ T } & \multicolumn{1}{c|}{ MX } & \multicolumn{1}{c|}{ MY } \\
\hline & & $\mathrm{kN}$ & $\mathrm{kN}$ & $\mathrm{kN}-\mathrm{m}$ & $\mathrm{kN}-\mathrm{m}$ & $\mathrm{kN}-\mathrm{m}$ \\
\hline 40 & Top & 661 & 662 & 13376 & 0 & 0 \\
\hline 40 & Bottom & 661 & 662 & 13376 & 2478 & 2472 \\
\hline 39 & Top & 1242 & 1241 & 25094 & 2473 & 2466 \\
\hline
\end{tabular}




\begin{tabular}{|c|c|c|c|c|c|c|}
\hline 39 & Bottom & 1242 & 1241 & 25094 & 7141 & 7131 \\
\hline 38 & Top & 1745 & 1739 & 35218 & 7141 & 7131 \\
\hline 38 & Bottom & 1745 & 1739 & 35218 & 13717 & 13716 \\
\hline 37 & Top & 2166 & 2156 & 43682 & 13716 & 13715 \\
\hline 37 & Bottom & 2166 & 2156 & 43682 & 21892 & 21917 \\
\hline 36 & Top & 2520 & 2505 & 50755 & 21892 & 21917 \\
\hline 36 & Bottom & 2520 & 2505 & 50755 & 31395 & 31459 \\
\hline 35 & Top & 2826 & 2810 & 56898 & 31395 & 31459 \\
\hline 35 & Bottom & 2826 & 2810 & 56898 & 42026 & 42134 \\
\hline 34 & Top & 3108 & 3092 & 62543 & 42026 & 42134 \\
\hline 34 & Bottom & 3108 & 3092 & 62543 & 53667 & 53810 \\
\hline 33 & Top & 3376 & 3361 & 67930 & 53667 & 53810 \\
\hline 33 & Bottom & 3376 & 3361 & 67930 & 66260 & 66423 \\
\hline 32 & Top & 3633 & 3618 & 73110 & 66260 & 66423 \\
\hline 32 & Bottom & 3633 & 3618 & 73110 & 79780 & 79945 \\
\hline 31 & Top & 3879 & 3863 & 78054 & 79779 & 79945 \\
\hline 31 & Bottom & 3879 & 3863 & 78054 & 94210 & 94362 \\
\hline 30 & Top & 4114 & 4097 & 82771 & 94210 & 94362 \\
\hline 30 & Bottom & 4114 & 4097 & 82771 & 109536 & 109661 \\
\hline 29 & Top & 4340 & 4324 & 87326 & 109536 & 109661 \\
\hline 29 & Bottom & 4340 & 4324 & 87326 & 125747 & 125829 \\
\hline 28 & Top & 4561 & 4547 & 91780 & 125746 & 125829 \\
\hline 28 & Bottom & 4561 & 4547 & 91780 & 142833 & 142856 \\
\hline 27 & Top & 4777 & 4763 & 96128 & 142833 & 142856 \\
\hline 27 & Bottom & 4777 & 4763 & 96128 & 160791 & 160737 \\
\hline 26 & Top & 4986 & 4971 & 100317 & 160791 & 160737 \\
\hline 26 & Bottom & 4986 & 4971 & 100317 & 179609 & 179463 \\
\hline 25 & Top & 5185 & 5170 & 104313 & 179609 & 179463 \\
\hline 25 & Bottom & 5185 & 5170 & 104313 & 199270 & 199018 \\
\hline 24 & Top & 5375 & 5361 & 108147 & 199270 & 199017 \\
\hline 24 & Bottom & 5375 & 5361 & 108147 & 219753 & 219380 \\
\hline 23 & Top & 5560 & 5548 & 111887 & 219753 & 219380 \\
\hline 23 & Bottom & 5560 & 5548 & 111887 & 241038 & 240528 \\
\hline 22 & Top & 5742 & 5732 & 115559 & 241038 & 240527 \\
\hline
\end{tabular}




\begin{tabular}{|c|c|c|c|c|c|c|}
\hline 22 & Bottom & 5742 & 5732 & 115559 & 263109 & 262441 \\
\hline 21 & Top & 5919 & 5909 & 119126 & 263108 & 262440 \\
\hline 21 & Bottom & 5919 & 5909 & 119126 & 285948 & 285102 \\
\hline 20 & Top & 6088 & 6079 & 122537 & 285947 & 285102 \\
\hline 20 & Bottom & 6088 & 6079 & 122537 & 309535 & 308493 \\
\hline 19 & Top & 6251 & 6242 & 125801 & 309534 & 308493 \\
\hline 19 & Bottom & 6251 & 6242 & 125801 & 333846 & 332591 \\
\hline 18 & Top & 6408 & 6401 & 128976 & 333846 & 332591 \\
\hline 18 & Bottom & 6408 & 6401 & 128976 & 358858 & 357372 \\
\hline 17 & Top & 6562 & 6556 & 132090 & 358858 & 357371 \\
\hline 17 & Bottom & 6562 & 6556 & 132090 & 384548 & 382812 \\
\hline 16 & Top & 6712 & 6704 & 135093 & 384548 & 382811 \\
\hline 16 & Bottom & 6712 & 6704 & 135093 & 410891 & 408889 \\
\hline 15 & Top & 6854 & 6844 & 137939 & 410890 & 408888 \\
\hline 15 & Bottom & 6854 & 6844 & 137939 & 437856 & 435576 \\
\hline 14 & Top & 6990 & 6980 & 140669 & 437855 & 435576 \\
\hline 14 & Bottom & 6990 & 6980 & 140669 & 465412 & 462846 \\
\hline 13 & Top & 7124 & 7114 & 143364 & 465412 & 462845 \\
\hline 13 & Bottom & 7124 & 7114 & 143364 & 493532 & 490669 \\
\hline 12 & Top & 7256 & 7244 & 146005 & 493531 & 490668 \\
\hline 12 & Bottom & 7256 & 7244 & 146005 & 522185 & 519019 \\
\hline 11 & Top & 7380 & 7365 & 148492 & 522185 & 519019 \\
\hline 11 & Bottom & 7380 & 7365 & 148492 & 551343 & 547872 \\
\hline 10 & Top & 7497 & 7481 & 150838 & 551342 & 547871 \\
\hline 10 & Bottom & 7497 & 7481 & 150838 & 580969 & 577194 \\
\hline 9 & Top & 7612 & 7597 & 153157 & 580968 & 577193 \\
\hline 9 & Bottom & 7612 & 7597 & 153157 & 611030 & 606954 \\
\hline 8 & Top & 7723 & 7706 & 155395 & 611029 & 606953 \\
\hline 8 & Bottom & 7723 & 7706 & 155395 & 641492 & 637121 \\
\hline 7 & Top & 7825 & 7805 & 157426 & 641491 & 637120 \\
\hline 7 & Bottom & 7825 & 7805 & 157426 & 672314 & 667658 \\
\hline 6 & Top & 7925 & 7907 & 159451 & 672313 & 667657 \\
\hline 6 & Bottom & 7925 & 7907 & 159451 & 703454 & 698528 \\
\hline 5 & Top & 8029 & 8008 & 161533 & 703453 & 698527 \\
\hline
\end{tabular}




\begin{tabular}{|r|l|r|r|r|r|r|}
\hline 5 & Bottom & 8029 & 8008 & 161533 & 734875 & 729695 \\
\hline 4 & Top & 8124 & 8101 & 163432 & 734874 & 729695 \\
\hline 4 & Bottom & 8124 & 8101 & 163432 & 766535 & 761126 \\
\hline 3 & Top & 8231 & 8209 & 165599 & 766535 & 761125 \\
\hline 3 & Bottom & 8231 & 8209 & 165599 & 798405 & 792791 \\
\hline 2 & Top & 8328 & 8304 & 167579 & 798404 & 792790 \\
\hline 2 & Bottom & 8328 & 8304 & 167579 & 830607 & 824808 \\
\hline 1 & Top & 8447 & 8420 & 170009 & 876010 & 870031 \\
\hline 1
\end{tabular}

\begin{tabular}{|c|c|c|c|c|c|}
\hline \multicolumn{6}{|c|}{ BEAM FORCES - MODEL 6} \\
\hline Story & Beam & $\mathbf{P}(\mathbf{k N})$ & V2 (kN) & $T(k N-m)$ & M3(kN-m) \\
\hline 40 & B11 & 0 & 4.4 & 0.13 & 16.3 \\
\hline 39 & B11 & 0.7075 & 4.9 & 0.18 & 14.6 \\
\hline 38 & B11 & 0.657 & 6.1 & 0.26 & 13.8 \\
\hline 37 & B11 & 0.5731 & 8.4 & 0.37 & 16.3 \\
\hline 36 & B11 & 0.5713 & 10.4 & 0.47 & 19.4 \\
\hline 35 & B11 & 0.5917 & 12.3 & 0.56 & 22.4 \\
\hline 34 & B11 & 0.618 & 14.0 & 0.63 & 25.2 \\
\hline 33 & B11 & 0.6347 & 15.6 & 0.70 & 28.2 \\
\hline 32 & B11 & 0.641 & 17.2 & 0.77 & 31.2 \\
\hline 31 & B11 & 0.6448 & 18.8 & 0.84 & 34.1 \\
\hline 30 & B11 & 0.6523 & 20.3 & 0.91 & 36.9 \\
\hline 29 & B11 & 0.6617 & 21.7 & 0.97 & 39.6 \\
\hline 28 & B11 & 0.6665 & 23.2 & 1.03 & 42.3 \\
\hline 27 & B11 & 0.6635 & 24.6 & 1.09 & 45.0 \\
\hline 26 & B11 & 0.6572 & 26.0 & 1.15 & 47.7 \\
\hline 25 & B11 & 0.6556 & 27.3 & 1.21 & 50.2 \\
\hline 24 & B11 & 0.6609 & 28.6 & 1.26 & 52.6 \\
\hline 23 & B11 & 0.6666 & 29.9 & 1.32 & 55.1 \\
\hline 22 & B11 & 0.6651 & 31.2 & 1.37 & 57.6 \\
\hline 21 & B11 & 0.6573 & 32.5 & 1.42 & 60.1 \\
\hline 20 & B11 & 0.6526 & 33.7 & 1.48 & 62.6 \\
\hline
\end{tabular}




\begin{tabular}{|c|c|c|c|c|c|}
\hline 19 & B11 & 0.6568 & 35.0 & 1.53 & 65.0 \\
\hline 18 & B11 & 0.6633 & 36.2 & 1.58 & 67.5 \\
\hline 17 & B11 & 0.6612 & 37.5 & 1.63 & 70.1 \\
\hline 16 & B11 & 0.6534 & 38.8 & 1.69 & 72.8 \\
\hline 15 & B11 & 0.6558 & 40.1 & 1.74 & 75.4 \\
\hline 14 & B11 & 0.6728 & 41.3 & 1.79 & 78.2 \\
\hline 13 & B11 & 0.6855 & 42.7 & 1.84 & 81.1 \\
\hline 12 & B11 & 0.6705 & 44.1 & 1.90 & 84.3 \\
\hline 11 & B11 & 0.6851 & 45.5 & 1.96 & 87.6 \\
\hline 10 & B11 & 0.7019 & 47.0 & 2.02 & 91.1 \\
\hline 9 & B11 & 0.7385 & 48.6 & 2.08 & 94.9 \\
\hline 8 & B11 & 0.7399 & 50.3 & 2.15 & 99.1 \\
\hline 7 & B11 & 0.7779 & 52.1 & 2.22 & 103.6 \\
\hline 6 & B11 & 0.8546 & 54.0 & 2.30 & 108.7 \\
\hline 5 & B11 & 0.8808 & 56.2 & 2.38 & 114.4 \\
\hline 4 & B11 & 0.9689 & 58.6 & 2.47 & 120.9 \\
\hline 3 & B11 & 1.1531 & 61.4 & 2.58 & 128.4 \\
\hline 2 & B11 & 1.2859 & 65.1 & 2.71 & 139.1 \\
\hline 1 & B11 & 8.2882 & 82.3 & 3.45 & 174.3 \\
\hline
\end{tabular}

\begin{tabular}{|r|l|r|r|r|r|}
\hline \multicolumn{7}{|c|}{ BEAM FORCES - MODEL 8 } \\
\hline \multicolumn{1}{|c|}{ Story } & \multicolumn{1}{|c|}{ Beam } & P (kN) & V2 (kN) & T(kN-m) & M3(kN-m) \\
\hline 40 & B11 & 0.00 & 16 & 0.46 & 56.8 \\
\hline 39 & B11 & 2.47 & 21 & 0.61 & 51.1 \\
\hline 38 & B11 & 2.29 & 29 & 17 & 48.3 \\
\hline 37 & B11 & 2.00 & 36 & 1.31 & 57.0 \\
\hline 36 & B11 & 2.00 & 43 & 1.95 & 67.8 \\
\hline 35 & B11 & 2.07 & 49 & 2.20 & 78.1 \\
\hline 34 & B11 & 2.16 & 54 & 2.45 & 98.5 \\
\hline 33 & B11 & 2.22 & 60 & 2.70 & 109.0 \\
\hline 32 & B11 & 2.24 & 71 & 2.94 & 119.2 \\
\hline 31 & B11 & 2.25 & 3.17 & 128.9 \\
\hline 30 & B11 & 2.28 & & & \\
\hline
\end{tabular}




\begin{tabular}{|c|c|c|c|c|c|}
\hline 29 & B11 & 2.31 & 76 & 3.38 & 138.4 \\
\hline 28 & B11 & 2.33 & 81 & 3.60 & 147.9 \\
\hline 27 & B11 & 2.32 & 86 & 3.81 & 157.3 \\
\hline 26 & B11 & 2.30 & 91 & 4.02 & 166.5 \\
\hline 25 & B11 & 2.29 & 95 & 4.22 & 175.4 \\
\hline 24 & B11 & 2.31 & 100 & 4.41 & 183.9 \\
\hline 23 & B11 & 2.33 & 104 & 4.60 & 192.4 \\
\hline 22 & B11 & 2.32 & 109 & 4.79 & 201.1 \\
\hline 21 & B11 & 2.30 & 113 & 4.97 & 209.9 \\
\hline 20 & B11 & 2.28 & 118 & 5.16 & 218.5 \\
\hline 19 & B11 & 2.29 & 122 & 5.34 & 227.1 \\
\hline 18 & B11 & 2.32 & 127 & 5.52 & 235.8 \\
\hline 17 & B11 & 2.31 & 131 & 5.70 & 244.9 \\
\hline 16 & B11 & 2.28 & 135 & 5.89 & 254.2 \\
\hline 15 & B11 & 2.29 & 140 & 6.07 & 263.5 \\
\hline 14 & B11 & 2.35 & 144 & 6.25 & 273.1 \\
\hline 13 & B11 & 2.39 & 149 & 6.44 & 283.3 \\
\hline 12 & B11 & 2.34 & 154 & 6.64 & 294.3 \\
\hline 11 & B11 & 2.41 & 159 & 6.85 & 305.9 \\
\hline 10 & B11 & 2.45 & 164 & 7.06 & 318.1 \\
\hline 9 & B11 & 2.58 & 170 & 7.28 & 331.5 \\
\hline 8 & B11 & 2.58 & 176 & 7.51 & 346.2 \\
\hline 7 & B11 & 2.72 & 182 & 7.76 & 362.0 \\
\hline 6 & B11 & 2.99 & 189 & 8.02 & 379.6 \\
\hline 5 & B11 & 3.08 & 196 & 8.32 & 399.7 \\
\hline 4 & B11 & 3.39 & 205 & 8.64 & 422.3 \\
\hline 3 & B11 & 4.03 & 215 & 9.01 & 448.4 \\
\hline 2 & B11 & 4.49 & 228 & 9.46 & 486.0 \\
\hline 1 & B11 & 28.95 & 287 & 12.04 & 609.0 \\
\hline
\end{tabular}


Appendix C: Etabs Modeling Procedure

MODEL SETUP

1. Materials: 30MPa Concrete

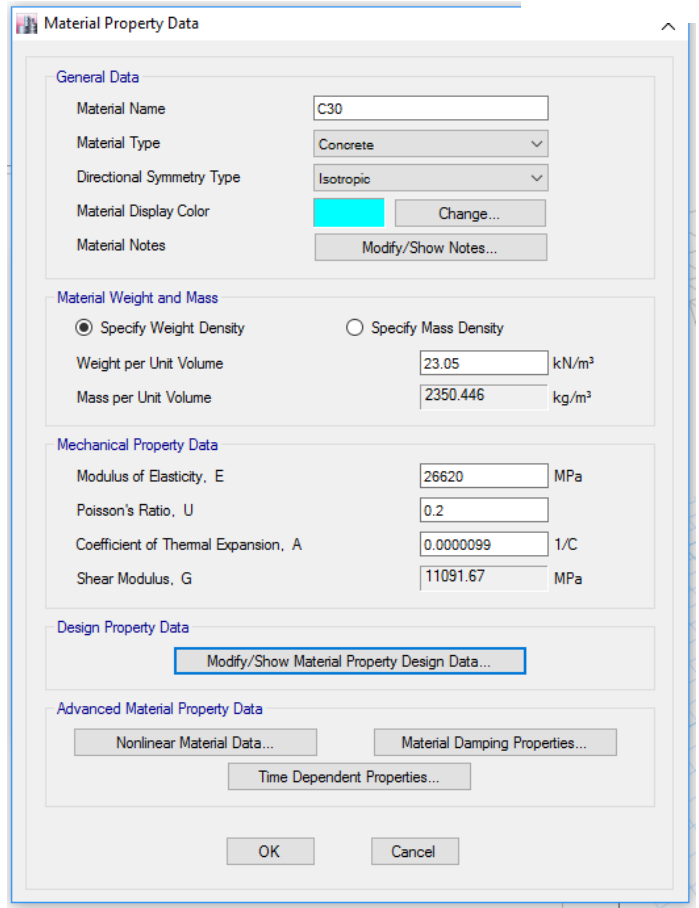

2. Members:

Walls: $\quad 400 \mathrm{~mm}$ Thick

Beams: $\quad 550 \mathrm{~mm}$ Wide $\times 1000 \mathrm{~mm}$ Deep

Columns: $\quad 550 \mathrm{~mm} \times 550 \mathrm{~mm}$

Slabs: $\quad 200 \mathrm{~mm}$ Deep 


\section{Stiffness Modifiers}

Stiffness of members reduced according to Clause 10.14.1 and 21.2.5.1 of CSA A23.3

\begin{tabular}{|c|c|c|c|}
\hline Member & Property & SLS Reduction Factor & ULS Reduction Factor \\
\hline \multirow{2}{*}{ Columns } & $\mathrm{GJ}$ & 0.2 & 0.15 \\
\cline { 2 - 4 } & $\mathrm{I}_{2}, \mathrm{I}_{3}$ & 1.0 & 0.7 \\
\hline \multirow{2}{*}{ Walls (Uncracked) } & $\mathrm{f}_{11}, \mathrm{f}_{22}, \mathrm{f}_{12}$ & 1.0 & 0.7 \\
\cline { 2 - 4 } & $\mathrm{m}_{11}, \mathrm{~m}_{22}, \mathrm{~m}_{12}$ & 0.35 & 0.35 \\
\hline \multirow{2}{*}{ Walls (Cracked) } & $\mathrm{f}_{11}, \mathrm{f}_{22}, \mathrm{f}_{12}$ & 0.5 & 0.35 \\
\cline { 2 - 4 } & $\mathrm{m}_{11}, \mathrm{~m}_{22}, \mathrm{~m}_{12}$ & 0.35 & 0.35 \\
\hline \multirow{2}{*}{ Floor Slabs } & $\mathrm{m}_{11}, \mathrm{~m}_{22}, \mathrm{~m}_{12}$ & 0.35 & 0.2 \\
\hline \multirow{2}{*}{ Typical Beams } & $\mathrm{GJ}$ & 0.2 & 0.15 \\
\cline { 2 - 4 } & $\mathrm{I}_{3}$ & 0.5 & 0.4 \\
\hline \multirow{2}{*}{ Coupling Beams } & $\mathrm{A}_{\mathrm{v} 2}$ & 1.0 & 0.15 \\
\cline { 2 - 4 } (Frame Section) & $\mathrm{GJ}$ & 0.2 & 0.15 \\
\cline { 2 - 4 } & $\mathrm{I}_{3}$ & 0.5 & 0.4 \\
\hline
\end{tabular}

\section{Mass Source}

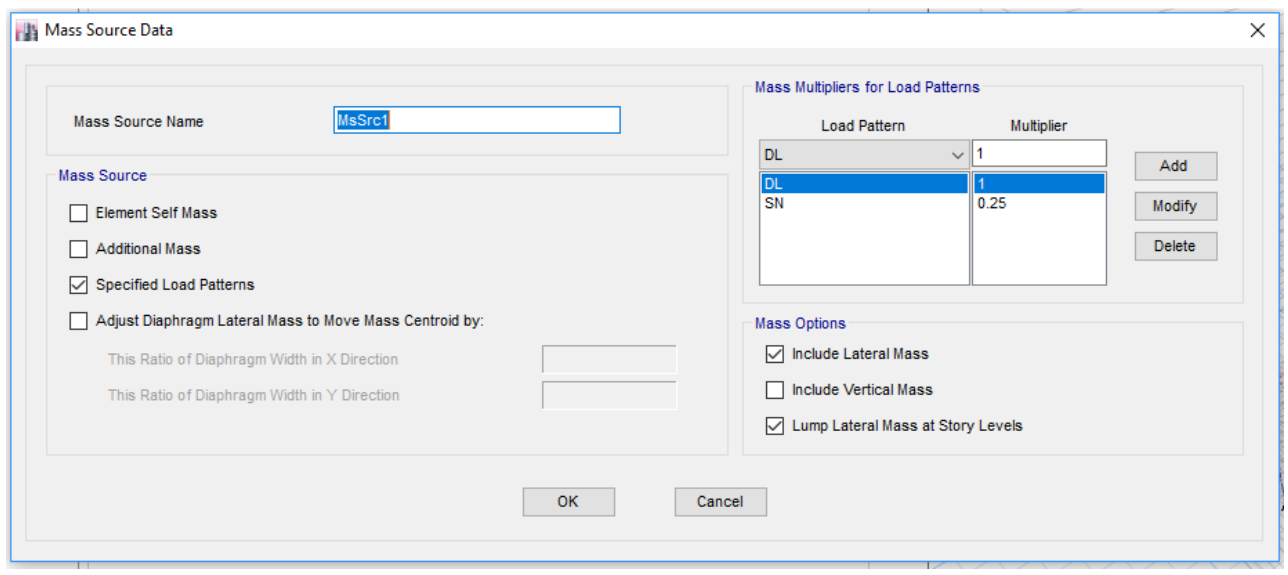

\section{P-Delta Options}

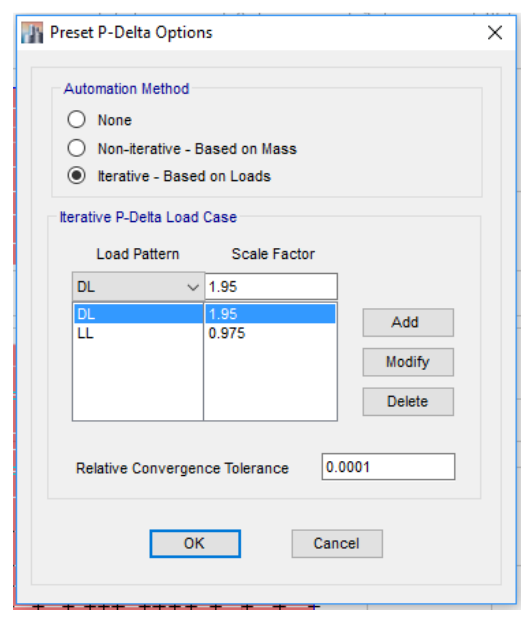




\section{Modal Cases}

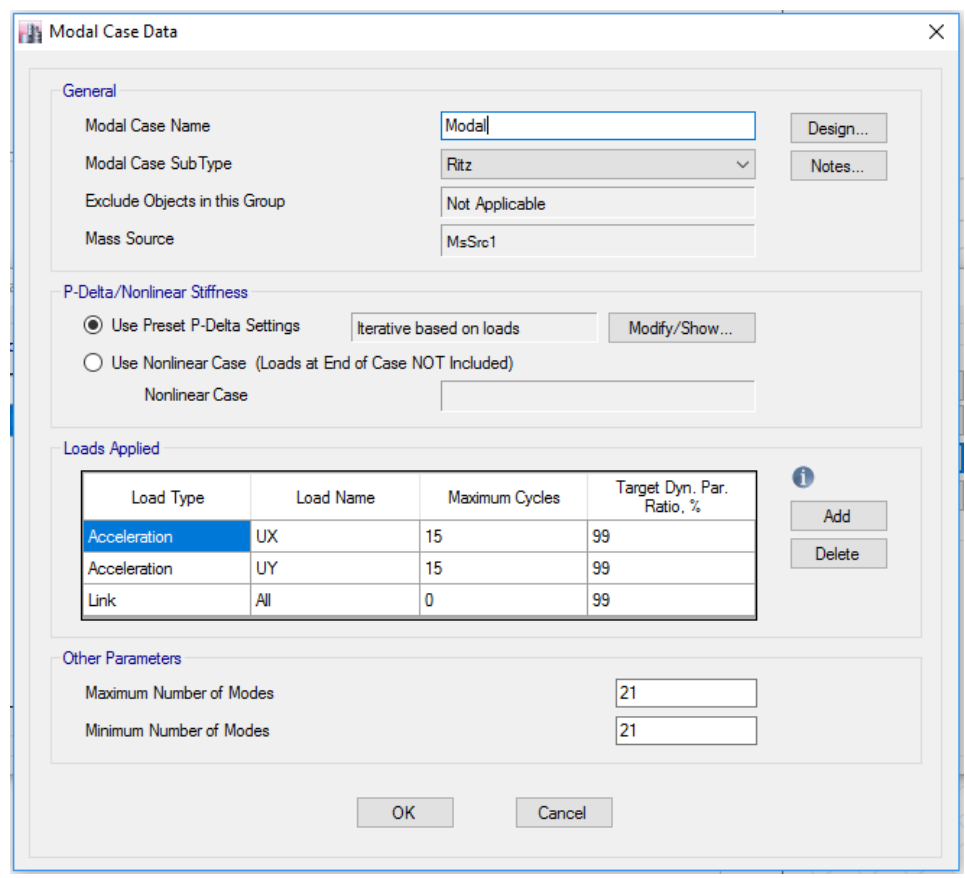

\section{LOADS:}

\section{Load Patterns/Cases}

\begin{tabular}{|c|c|c|l|}
\hline Num & Name & Load & \multicolumn{1}{c|}{ Description } \\
\hline 1 & DL & Dead Load & Self-weight and superimposed dead load \\
\hline 2 & LL & Live Load & Live loads based on associated occupancy \\
\hline 3 & SN & Snow & Snow loading including drifts \\
\hline
\end{tabular}

\section{Floor Load:}

a. Surface loads applied directly to slab elements

b. Line loads applied to frame elements such as beams. These frame elements shall in turn be fully supported by slab elements.

c. Point loads applied to the nodes of slab elements.

\section{Lateral Loads:}

a. Scale factor e calculated as $g \times I_{E} /\left(R_{d} R_{0}\right)$, where $g$ is the standard acceleration due to gravity. for $\mathrm{IE}_{\mathrm{E}}=1, \mathrm{R}_{\mathrm{d}}=1.5, \mathrm{R}_{\mathrm{o}}=1.3$ and metre as unit of length, Scale Factor shall be 5.031 . 


\begin{tabular}{|c|c|}
\hline S.F. $=\begin{array}{c}\mathrm{g \times I_{E }} \\
\mathrm{R}_{\mathrm{d}} \times \mathrm{R}_{\mathrm{o}}\end{array}$ & $\begin{array}{l}\frac{\text { Where }}{\mathrm{g}=\text { gravity }\left(9.81 \mathrm{~m} / \mathrm{s}^{2}\right)} \\
\mathrm{IE}=\text { Importance Factor } \\
\text { Rd = Ductility Factor }\end{array}$ \\
\hline $\begin{array}{c}\text { Normal Importance Conventional } \\
\text { Construction: } \\
\text { S.F. }=\mathbf{5 . 0 3 1}\end{array}$ & $\begin{array}{l}\mathrm{IE}=1.0 \\
\mathrm{Rd}=1.5 \\
\mathrm{Ro}=1.3\end{array}$ \\
\hline
\end{tabular}

b. "Modal Load Case for "Modal Combination Method". Select SRSS for "Directional Combination Type".

c. "Diaphragm Eccentricity" 0.05 as required bycode.

d. Lateral Siesmic loads patterns:

\begin{tabular}{|c|c|c|c|}
\hline Num & Name & Load & Description \\
\hline 1 & SPECX & \multirow{4}{*}{$\begin{array}{c}\text { Dynamic } \\
\text { Earthquake }\end{array}$} & $\begin{array}{l}\text { SPECX - straight earthquake force in X direction (and } \\
\text { straight earthquake force in X direction, plus } 30 \% \text { of } \\
\text { SPECY if required by } 4.1 .8 .8 \text { (1).(c) of OBC 2012) }\end{array}$ \\
\hline 2 & SPECXE & & $\begin{array}{l}\text { SPECXE - earthquake force plus accidental torsion in X } \\
\text { direction (and earthquake force plus accidental torsion } \\
\text { in X direction, plus } 30 \% \text { of SPECYE if required by }\end{array}$ \\
\hline 3 & SPECY & & $\begin{array}{l}\text { SPECY - straight earthquake force in Y direction (and } \\
\text { straight earthquake force in Y direction, plus } 30 \% \text { of } \\
\text { SPECX if required by 4.1.8.8.(1).(c) of OBC 2012) }\end{array}$ \\
\hline 4 & SPECYE & & $\begin{array}{l}\text { SPECYE - earthquake force plus accidental torsion in Y } \\
\text { direction (and earthquake force plus accidental torsion } \\
\text { in Y direction, plus } 30 \% \text { of SPECXE if required by } \\
\text { 4.1.8.8.(1).(c) of OBC 2012) }\end{array}$ \\
\hline
\end{tabular}

4. Load Combinations:

a. All loading combinations are derived based on the following principle of permanent and variable loads as described in the NBC 2015 Structural Commentaries (Part 4 of Division B). See Table below.

b. 


\begin{tabular}{|c|c|c|c|}
\hline \multirow[b]{2}{*}{ Case } & \multicolumn{3}{|c|}{ Load Combinations } \\
\hline & Principal Loads & $\begin{array}{l}\text { Secondary } \\
\text { Principal }\end{array}$ & Companion Loads \\
\hline 1 & $1.4 \mathrm{D}$ & - & - \\
\hline $2 a$ & \multirow{4}{*}{$(1.25 \mathrm{D}+1.5 \mathrm{~L}$ or $1.25 \mathrm{~L})$} & \multirow{4}{*}{$\begin{array}{c}1.5 \mathbf{H}^{(1)} \\
1.25 \mathbf{T}^{(1)} \\
1.0 \mathbf{P}^{(1)}\end{array}$} & - (1) \\
\hline $2 b$ & & & $1.0 \mathbf{S}^{(6)}$ \\
\hline $2 \mathrm{c}$ & & & $1.0 L_{\text {Roof }}^{\text {iol }}$ \\
\hline $2 d$ & & & $0.4 \mathrm{~W}$ \\
\hline $2 d$ & \multirow{4}{*}{$0.9 D^{(4)}+(1.5 \mathrm{~L} \text { or } 1.25 \mathrm{~L})^{(5)}$} & \multirow{4}{*}{$\begin{array}{c}1.5 \mathbf{H}^{(1)} \\
1.25 \mathbf{T}^{(1)} \\
1.0 \mathbf{P}^{(1)}\end{array}$} & $-(1)$ \\
\hline $2 \mathrm{e}$ & & & $1.0 \mathbf{S}^{(6)}$ \\
\hline $2 f$ & & & $1.0 L_{\text {Roo }}{ }_{f}^{c}$ \\
\hline $2 \mathrm{~g}$ & & & $0.4 \mathrm{~W}$ \\
\hline $3 a$ & \multirow{3}{*}{$(1.25 \mathrm{D})^{(3)}+1.5 \mathrm{~S}$} & \multirow{3}{*}{$\begin{array}{c}1.5 \mathbf{H}^{(1)} \\
1.25 \mathbf{T}^{(1)} \\
1.0 \mathbf{P}^{(1)} \\
\end{array}$} & - (1) \\
\hline $3 b$ & & & $(0.5 \mathrm{~L} \text { or } 1.0 \mathrm{~L})^{(6)(7)}$ \\
\hline $3 c$ & & & $0.4 \mathrm{~W}$ \\
\hline $3 d$ & \multirow[b]{3}{*}{$0.9 \mathrm{D}^{(4)}+1.5 \mathrm{~S}$} & \multirow{3}{*}{$\begin{array}{c}1.5 \mathbf{H}^{(1)} \\
1.25 \mathbf{T}^{(1)} \\
1.0 \mathbf{P}^{(1)}\end{array}$} & $-(1)$ \\
\hline $3 e$ & & & $(0.5 \mathrm{~L} \text { or } 1.0 \mathrm{~L})^{(6)(7)}$ \\
\hline $3 f$ & & & $0.4 \mathrm{~W}$ \\
\hline $4 a$ & \multirow{3}{*}{$1.25 D^{(3)}+1.4 W$} & \multirow{3}{*}{$\begin{array}{c}1.5 \mathbf{H}^{(1)} \\
1.25 \mathbf{T}^{(1)} \\
1.0 \mathbf{P}^{(1)}\end{array}$} & -(1) \\
\hline $4 \mathrm{~b}$ & & & $(0.5 \mathrm{~L} \text { or } 1.0 \mathrm{~L})^{(7)}$ \\
\hline $4 c$ & & & $0.5 \mathrm{~S}$ \\
\hline $4 d$ & \multirow[b]{3}{*}{$0.9 \mathbf{D}^{(4)}+1.4 \mathrm{~W}$} & \multirow{3}{*}{$\begin{array}{c}1.5 \mathbf{H}^{(1)} \\
1.25 \mathbf{T}^{(1)} \\
1.0 \mathbf{P}^{(1)}\end{array}$} & - (1) \\
\hline $4 e$ & & & $(0.5 \mathrm{~L} \text { or } 1.0 \mathrm{~L})^{(7)}$ \\
\hline $4 f$ & & & $0.5 \mathrm{~S}$ \\
\hline $5 a$ & \multirow{2}{*}{$1.0 \mathbf{D}^{(4)}+1.0 \mathrm{E}^{(8)}$} & \multirow{2}{*}{$1.0 \mathbf{H}^{(1)}$} & $-(1)$ \\
\hline $5 b$ & & & $(0.5 \mathrm{~L} \text { or } 1.0 \mathrm{~L})^{(6)(7)}+0.25 \mathbf{S}^{(6)}$ \\
\hline
\end{tabular}

\section{MODELING:}

1. Slab/Wall Meshing

a. Slabs and walls automatically meshed at $2 \mathrm{~m}$ increments for all 8 models. Mesh also constrained to maximum 2:1 aspect ratio.

b. "Auto Line Constraint" applied to the whole model.

c. Releasing Frame Elements:

Release only one end - Ensure load transfer between elements.

d. Coupling beams modeled as frame elements.

e. Diaphragm Assignment: Semi Rigid 


\section{POST-ANALYSIS MODEL VERIFICATION}

\section{Last Analysis run log checked to verify the following items:}

a. Verify there are no negative stiffness, structural instability, ill-conditioned structure, or lost digits of accuracy.

b. P-Delta iteration has converged.

c. Global force balance should be reasonably small. The difference reported in Last Analysis Run Log shall have differences in FX, FY and FZ that are smaller than 0.001 and usually around 1x10-5 while those in MX, MY and MZ shall be less than 5 and usually around 0.01 .

d. Mode shapes reviewed after analysis and trivial modes due to insufficient restraint/constraint of specific members were eliminated.

e. Modal participating mass ratios shall be checked:

i. SumUX and SumUY of the last mode shall be greater than 90, preferably 95 . Otherwise the maximum number of modes were increased: The Maximum Number of Modes increased until SumUX and SumUY of the last mode are greater than 90 


\section{Appendix D: NBCC 2015 Seismic Provisions}

Seismic Data for Montreal:

Table C-3

Seismic Design Data for Selected Locations in Canada

\begin{tabular}{|c|c|c|c|c|c|c|c|c|}
\hline \multirow{2}{*}{ Province and Location } & \multicolumn{8}{|c|}{ Seismic Data } \\
\hline & $\mathrm{S}_{\mathrm{a}}(0.2)$ & $\mathrm{S}_{\mathrm{a}}(0.5)$ & $\mathrm{S}_{\mathrm{a}}(1,0)$ & $S_{a}(2.0)$ & $\mathrm{S}_{\mathrm{a}}(5.0)$ & $\mathrm{S}_{\mathrm{a}}(10.0)$ & PGA & PGV \\
\hline Dorval & 0.600 & 0.316 & 0.151 & 0.069 & 0.018 & 0.0062 & 0.382 & 0.259 \\
\hline Laval & 0.595 & 0311 & 0.148 & 0068 & 0.018 & 0.0062 & 0.379 & 0.256 \\
\hline Montréal (City Hall) & 0.595 & 0.311 & 0.148 & 0.068 & 0.018 & 0.0062 & 0.379 & 0.255 \\
\hline Montréal-Est & 0.586 & 0.305 & 0.145 & 0.067 & 0.017 & 0.0062 & 0.374 & 0.250 \\
\hline Montréal-Nord & 0.593 & 0.309 & 0.147 & 0.068 & 0.017 & 0.0062 & 0.378 & 0.254 \\
\hline
\end{tabular}

For determining $\mathrm{PGA}_{\text {ref }}$ per $\mathrm{Cl}$ 4.1.8.4.(4):

a) $0.8 \mathrm{PGA}$, where the ratio $\mathrm{S}_{\mathrm{a}}(0.2) / \mathrm{PGA}<2.0$, and

b) PGA, otherwise.

For determining site class coefficient per Table 4.1.8.4.(B - G): Therefore, using linear interpolation for

$\mathrm{PGA}_{\text {ref }}=.303 \mathrm{~s}$

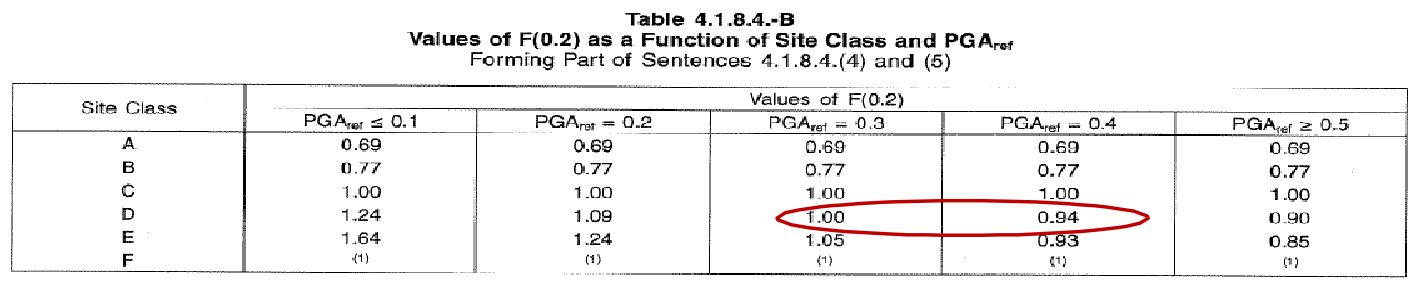

Table 4.1.8.4.-C

Values of $\mathbf{F}(0.5)$ as a Function of Site Class and PGA $\mathbf{A}_{\text {ret }}$ Forming Part of Sentences 4.1.8.4.(4) and (5)

\begin{tabular}{|c|c|c|c|c|c|}
\hline \multirow{2}{*}{ Site Classs } & \multicolumn{5}{|c|}{ Values of $F(0.5)$} \\
\hline & $\mathrm{PGA}_{\text {yet }} \leq 0.1$ & $\mathrm{PGA}_{\text {iel }}=0.2$ & $P G A_{\text {ref }}=0.3$ & $P G A_{p p t}=0.4$ & $P G A_{r a t} \geq 0.5$ \\
\hline A & 0.57 & 0.57 & 0.57 & 0.57 & 0.57 \\
\hline $\mathrm{B}$ & 0.65 & 0.05 & 0.65 & 0.65 & 0.65 \\
\hline $\mathrm{c}$ & 1.00 & 1.00 & 1.00 & 1.00 & 1.00 \\
\hline D & 1.47 & 1.30 & 1.20 & 1.14 & 1.10 \\
\hline E & 2.17 & 1.80 & 1.48 & 1.30 & 1.17 \\
\hline $\mathbf{F}$ & (1) & (1) & (1) & (1) & (3) \\
\hline
\end{tabular}

Table 4.1.8.4.-D

Values of $F(1.0)$ as a Function of Site Class and PGA Forming Part of Sentences 4.1.8.4.(4) and (5)

\begin{tabular}{|c|c|c|c|c|c|}
\hline \multirow{2}{*}{ Site Class } & \multicolumn{5}{|c|}{ Values of $F(1.0)$} \\
\hline & $P G A_{\text {ref }} \leq 0.1$ & $P G A_{\text {sof }}=0.2$ & $P G A_{\text {rat }}=0.3$ & $\mathrm{PGA}_{\mathrm{ref}}=0.4$ & $P G A_{\text {ref }} \geq 0.5$ \\
\hline A & 0.57 & 0.57 & 0.57 & 0.57 & 0.57 \\
\hline B & 0.63 & 0.63 & 0.63 & 0.63 & 0.63 \\
\hline C & 1.00 & 1.00 & 1.00 & 1.00 & 1.00 \\
\hline D & 1.55 & 1.39 & 1.31 & 1.25 & 1.21 \\
\hline$E$ & 2.81 & 2.08 & 1.74 & 1.53 & 1.39 \\
\hline $\mathrm{F}$ & (1) & (1) & (1) & (1) & (1) \\
\hline
\end{tabular}

Table 4.1.8.4.-E

Values of $F(2.0)$ as a Function of Site Class and PGA ref Forming Part of Sentences 4.1.8.4.(4) and (5)

\begin{tabular}{|c|c|c|c|c|c|}
\hline \multirow{2}{*}{ Site Class } & \multicolumn{5}{|c|}{ Values of $F(2.0)$} \\
\hline & $\mathrm{PGA}_{\text {ret }} \leq 0.1$ & $\mathrm{PGA}_{\mathrm{ref}}=0.2$ & $P G A_{\text {ref }}=0.3$ & $\mathrm{PGA}_{\text {ret }}=0.4$ & $P G A_{\text {ret }} \geq 0.5$ \\
\hline A & 0.58 & 0.58 & 0.58 & 0.58 & 0.58 \\
\hline B & 0.63 & 0.63 & 0.63 & 0.63 & 0.63 \\
\hline $\mathrm{C}$ & 1.00 & 1.00 & 1.00 & 1.00 & 1.00 \\
\hline D & 1.57 & 1.44 & 1.36 & 1.31 & 1.27 \\
\hline$E$ & 2.90 & 2.24 & 1.92 & 1.72 & 1.58 \\
\hline $\mathrm{F}$ & (1) & (1) & (1) & (1) & (1) \\
\hline
\end{tabular}


Table 4.1.8.4.-F

Values of $F(5.0)$ as a Function of Site Class and $P G A_{\text {ref }}$

Forming Part of Sentences 4.1.8.4.(4) and (5)

\begin{tabular}{|c|c|c|c|c|c|}
\hline \multirow{2}{*}{ Site Class } & \multicolumn{5}{|c|}{ Values of $F(5.0)$} \\
\hline & $P G A_{\text {ret }} \leq 0.1$ & $P G A_{\text {ref }}=0.2$ & $P G A_{\text {ref }}=0.3$ & $P G A_{\text {ref }}=0.4$ & $P G A_{\text {ret }} \geq 0.5$ \\
\hline A & 0.61 & 0.61 & 0.61 & 0.61 & 0.61 \\
\hline B & 0.64 & 0.64 & 0.64 & 0.64 & 0.64 \\
\hline C & 1.00 & 1.00 & 1.00 & 1.00 & 1.00 \\
\hline D & 1.58 & 1.48 & 1.41 & 1.37 & 1.34 \\
\hline$E$ & 2.93 & 2.40 & 2.14 & 1.96 & 1.84 \\
\hline $\mathrm{F}$ & (1) & (1) & (1) & (1) & (1) \\
\hline
\end{tabular}

\begin{tabular}{|l|l|l|l|l|l|}
\hline & $\mathrm{T} \leq 0.2$ & $\mathrm{~T}=0.5$ & $\mathrm{~T}=1.0$ & $\mathrm{~T}=2.0$ & $\mathrm{~T}=5.0$ \\
\hline $\mathrm{Sa}(\mathrm{T})$ & 0.595 & 0.311 & 0.148 & 0.068 & 0.018 \\
\hline $\mathrm{F}(\mathrm{T})$ & 0.998 & 1.198 & 1.308 & 1.358 & 1.409 \\
\hline $\mathrm{S}(\mathrm{T})$ & 0.594 & 0.373 & 0.194 & 0.092 & 0.025 \\
\hline
\end{tabular}

For determining design spectral analysis $\mathrm{S}(\mathrm{T})$ per $\mathrm{Cl}$ 4.1.8.4.(9):

$$
\begin{aligned}
\mathrm{S}(\mathrm{T}) & =\mathrm{F}(0.2) \mathrm{S}_{\mathrm{a}}(0.2) \text { or } \mathrm{F}(0.5) \mathrm{S}_{\mathrm{a}}(0.5), \text { whichever is larger, for } \mathrm{T} \leq 0.2 \mathrm{~s} \\
& =\mathrm{F}(0.5) \mathrm{S}_{\mathrm{a}}(0.5) \text { for } \mathrm{T}=0.5 \mathrm{~s} \\
& =\mathrm{F}(1.0) \mathrm{S}_{\mathrm{a}}(1.0) \text { for } \mathrm{T}=1.0 \mathrm{~s} \\
& =\mathrm{F}(2.0) \mathrm{S}_{\mathrm{a}}(2.0) \text { for } \mathrm{T}=2.0 \mathrm{~s} \\
& =\mathrm{F}(5.0) \mathrm{S}_{\mathrm{a}}(5.0) \text { for } \mathrm{T}=5.0 \mathrm{~s} \\
& =\mathrm{F}(10.0) \mathrm{S}_{\mathrm{a}}(10.0) \text { for } \mathrm{T} \geq 10.0 \mathrm{~s}
\end{aligned}
$$

Direction of Loading

Both orthogonal directions $(\mathrm{SFRS})=$ Ductile Shear Wall, $\mathrm{R}_{\mathrm{D}}=3.5$ and $\mathrm{R}_{\mathrm{O}}=1.6$

Both orthogonal directions $(\mathrm{SFRS})=$ Ductile Moment Frame, $\mathrm{R}_{\mathrm{D}}=4.0$ and $\mathrm{R}_{\mathrm{O}}=1.7$

For building period, Ts per $\mathrm{Cl}$ 4.1.8.1.(7):

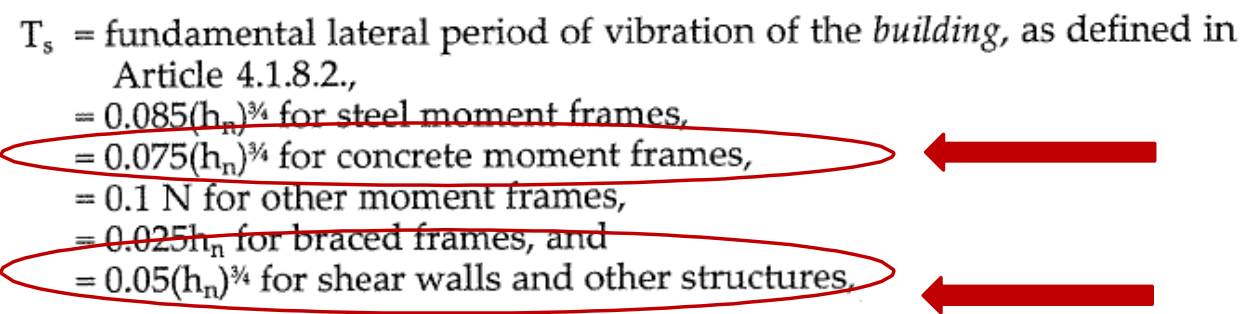


For determining force modifications factors $\mathrm{R}_{\mathrm{D}}$ and $\mathrm{R}_{\mathrm{O}}$ Table4.1.8.9:

Table 4.1.8.9. (Continued)

\begin{tabular}{|c|c|c|c|c|c|c|c|}
\hline \multirow{3}{*}{ Type of SFRS } & \multirow{3}{*}{$R_{d}$} & \multirow{3}{*}{$\mathrm{R}_{0}$} & \multicolumn{5}{|c|}{ Restrictions (2) } \\
\hline & & & \multicolumn{4}{|c|}{ Cases Where $I_{E} F_{a} S_{a}(0.2)$} & \multirow{2}{*}{$\begin{array}{c}\text { Cases } \\
\text { Where } \\
\mathrm{I}_{\mathrm{E}} \mathrm{F}_{\mathrm{v}} \mathrm{S}_{\mathrm{a}}(1.0) \\
>0.3\end{array}$} \\
\hline & & & $<0.2$ & $\begin{array}{c}\geq 0.2 \text { to }< \\
0.35\end{array}$ & $\begin{array}{c}\geq 0.35 \text { to } \\
\leq 0.75\end{array}$ & $>0.75$ & \\
\hline \multicolumn{8}{|c|}{ Concrete Structures Designed and Detailed According to CSA A23.3 } \\
\hline Ductile moment-resisting frames & 4.0 & 1.7 & NL & NL & NL & NL & NL \\
\hline Moderately ductile moment-resisting frames & 2.5 & 1.4 & NL & $\mathrm{NL}$ & 60 & 40 & 40 \\
\hline Ductile coupled walls & 4.0 & 1.7 & NL & $\mathrm{NL}$ & $\mathrm{NL}$ & $\mathrm{NL}$ & NL \\
\hline Moderately ductile coupled walls & 2.5 & 1.4 & $\mathrm{NL}$ & NL & NL & 60 & 60 \\
\hline Ductile partially coupled walls & 3.5 & 1.7 & NL & $\mathrm{NL}$ & $\mathrm{NL}$ & $\mathrm{NL}$ & $\mathrm{NL}$ \\
\hline Moderately ductile partially coupled walls & 2.0 & 1.4 & NL & NL & $\mathrm{NL}$ & 60 & 60 \\
\hline Ductile shear walls & 3.5 & 1.6 & NL & NL & $\mathrm{NL}$ & $\mathrm{NL}$ & NL \\
\hline Moderately ductile shear walls & 2.0 & 1.4 & $\mathrm{NL}$ & NL & NL & 60 & 60 \\
\hline \multicolumn{8}{|l|}{ Conventional construction } \\
\hline Moment-resisting frames & 1.5 & 1.3 & NL & NL & 20 & 15 & $10^{(5)}$ \\
\hline Shear walls & 1.5 & 1.3 & NL & NL & 40 & 30 & 30 \\
\hline Two-way slabs without beams & 1.3 & 1.3 & 20 & 15 & NP & $\mathrm{NP}$ & NP \\
\hline
\end{tabular}

Development of Equivalent Lateral Forces

Lateral earthquake force V shall be determined per $\mathrm{Cl}$ 4.1.8.11 (2)

$$
\mathrm{V}=\mathrm{S}\left(\mathrm{T}_{\mathrm{a}}\right) \mathrm{M}_{\mathrm{v}} \mathrm{I}_{\mathrm{E}} \mathrm{W} /\left(\mathrm{R}_{\mathrm{d}} \mathrm{R}_{\mathrm{o}}\right)
$$

Minimum lateral earthquake force $\mathrm{V}_{\min }$ shall be:

a) for walls, coupled walls and wall-frame systems, V shall not be less than

$$
\mathrm{S}(4.0) \mathrm{M}_{\mathrm{v}} \mathrm{I}_{\mathrm{E}} \mathrm{W} /\left(\mathrm{R}_{\mathrm{d}} \mathrm{R}_{\mathrm{o}}\right)
$$

Maximum lateral earthquake force $\mathrm{V}_{\max }$ shall be:

c) for buildings located on a site other than Class F and having an SFRS with an $R_{d}$ equal to or greater than $1.5, V$ need not be greater than the larger of

$$
\begin{gathered}
\frac{2}{3} \mathrm{~S}(0.2) \mathrm{I}_{\mathrm{E}} \mathrm{W} /\left(\mathrm{R}_{\mathrm{d}} \mathrm{R}_{\mathrm{o}}\right) \text { and } \\
\mathrm{S}(0.5) \mathrm{I}_{\mathrm{E}} \mathrm{W} /\left(\mathrm{R}_{\mathrm{d}} \mathrm{R}_{\mathrm{o}}\right)
\end{gathered}
$$


Building period limitations per $\mathrm{Cl}$ 4.1.8.11(3)(d)(iii)

iii) for shear wall structures, $\mathrm{T}_{\mathrm{a}}$ shall not be taken greater than 2.0 times that determined in Clause (c),

For determining weight of the building, W per $\mathrm{Cl}$ 4.1.8.11(5)

$$
\mathrm{W}=\sum_{\mathrm{i}=1}^{\mathrm{n}} \mathrm{W}_{\mathrm{i}}
$$

For determining the lateral force Fx applied to level x per Cl4.1.8.11(7)

$$
F_{x}=\left(V-F_{t}\right) W_{x} h_{x} /\left(\sum_{i=1}^{n} W_{i} h_{i}\right)
$$

For determining the Higher Mode Factor, $\mathrm{M}_{\mathrm{v}}$ and Base Overturning Reduction factor, J using interpolation per Table 4.1.8.11

Table 4.1.8.11.

Higher Mode Factor, $\mathbf{M}_{\mathrm{v}}$, and Base Overturning Reduction Factor, $J^{(1)(2)(3)(4)}$

\begin{tabular}{|c|c|c|c|c|c|c|c|c|}
\hline $\mathrm{S}(0.2) / \mathrm{S}(5.0)$ & $M_{v}$ for $T_{a} \leq 0.5$ & $M_{v}$ for $T_{a}=1.0$ & $M_{v}$ for $T_{a}=2.0$ & $M_{v}$ for $T_{a} \geq 5.0$ & $\mathrm{~J}$ for $T_{\mathrm{A}} \leq 0.5$ & $\mathrm{~J}$ for $T_{A}=1.0$ & $\mathrm{~J}$ for $T_{\mathrm{a}}=2.0$ & $J$ for $T_{2} \geq 5.0$ \\
\hline \multicolumn{9}{|c|}{ Walls, Wall Frame Systems } \\
\hline 5 & 1 & & & $1.25(7)$ & 1 & 0.97 & -085 & $0.55^{(8)}$ \\
\hline 20 & 1 & & & $2.30(7)$ & 1 & 0.80 & 0.60 & $0.35(8)$ \\
\hline 40 & 1 & 19 & & $3.70(7)$ & 1 & 0.63 & 0.46 & $0.28^{(8)}$ \\
\hline 65 & 1 & 1.55 & 2.25 & $4.65(7)$ & 1 & 0.51 & 0.39 & $0.23^{(8)}$ \\
\hline \multicolumn{9}{|c|}{ Coupled Walls(6) } \\
\hline 5 & 1 & & & $1(7)$ & 1 & 0.97 & 0.92 & $0.80^{(\theta)}$ \\
\hline 0 & 1 & & & $1.08(7)$ & 1 & 0.93 & 0.85 & $0.65(8)$ \\
\hline & 1 & & & $1.30(7)$ & 1 & 0.87 & 0.78 & $0.53^{(8)}$ \\
\hline 65 & 1 & 1 & 1.03 & $1.49(7)$ & 1 & 0.80 & 0.70 & $0.46(8)$ \\
\hline
\end{tabular}
Forming Part of Sentence 4.1.8.11.(6)

For determining the Overturning Moment and level x, Mx applied to level x per Cl4.1.8.11(8)

$$
\mathrm{M}_{\mathrm{x}}=\mathrm{J}_{\mathrm{x}} \sum_{\mathrm{i}=\mathrm{x}}^{\mathrm{n}} \mathrm{F}_{\mathrm{i}}\left(\mathrm{h}_{\mathrm{i}}-\mathrm{h}_{\mathrm{x}}\right)
$$


Dynamic Analysis Procedure requirements per Cl. 4.1.8.12

\subsubsection{Methods of Analysis}

1) Analysis for design earthquake actions shall be carried out in accordance with the Dynamic Analysis Procedure described in Article 4.1.8.12. (see Note A-4.1.8.7.(1)), except that the Equivalent Static Force Procedure described in Article 4.1.8.11. may be used for structures the following criteria:

a) in cases where $\mathrm{I}_{\mathrm{E}} \mathrm{F}_{\mathrm{a}} \mathrm{S}_{\mathrm{a}}(0.2)$ is less than 0.35 Dynamic analysis required

b) regular structures that are less than $60 \mathrm{~m}$ in height and have a fundamental lateral period, $\mathrm{T}_{\mathrm{a}}$ less than $2 \mathrm{~s}$ in each of two orthogonal directions as defined in Article 4.1.8.8., or

c) structures with structural irregularity, of Type 1, 2, 3, 4, 5, 6 or 8 as defined in Table 4.1.8.6., that are less than $20 \mathrm{~m}$ in height and have a fundamental lateral period, $\mathrm{T}_{\mathrm{a}}$, less than $0.5 \mathrm{~s}$ in each of two orthogonal directions as defined in Article 4.1.8.8. 


\section{Appendix E: NBCC 2015 Equivalent Lateral Force Procedure Results}

Project: $\quad$ L_SW_D

Number: $\quad$ Model 1

$\mathrm{X}$

Direction: direction
Location:

Montreal

Total Number of Floors, $\mathrm{N}_{\mathrm{TL}}=$

Climatic Data and Structural Parameters

\begin{tabular}{|c|c|c|c|c|c|c|c|c|c|}
\hline $\mathrm{q}$ & $\mathrm{S}_{\mathrm{a}}(0.2)$ & $\mathrm{S}_{\mathrm{a}}(0.5)$ & $\mathrm{S}_{\mathrm{a}}(1.0)$ & $\mathrm{S}_{\mathrm{a}}(2.0)$ & $\mathrm{PGA}$ & $\mathrm{F}_{\mathrm{a}}$ & $\mathrm{F}_{\mathrm{v}}$ & $\mathrm{M}_{\mathrm{v}}$ & $\mathrm{J}$ \\
\hline 0.42 & 0.594 & 0.373 & 0.194 & 0.092 & 0.303 & 1.2 & 1.3 & 1.043 & 0.809 \\
\hline
\end{tabular}
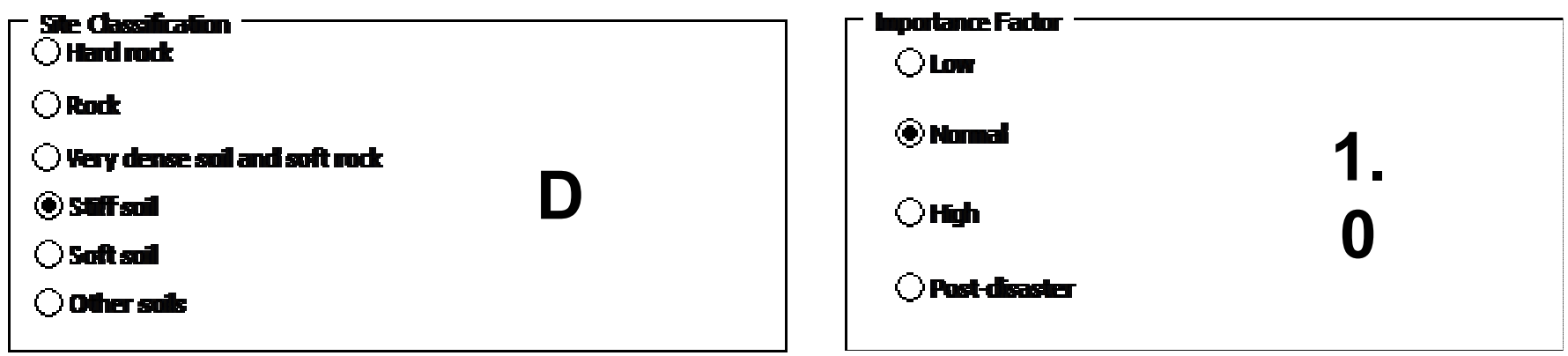

\section{The of sins}

Concrete_Ductile shear walls
$\mathrm{R}_{\mathrm{d}}=$
3.5
$\mathrm{R}_{\mathrm{o}}=$
1.6

$\begin{array}{rrrrrr}\mathrm{T}_{\mathrm{a}, \text { etabs }} & 1.217 & \mathrm{~s} & \mathrm{~T}_{\mathrm{a}}= & 1.217 & \mathrm{~s} \\ \mathrm{~T}_{\mathrm{a}, \text { code }}= & 0.869 & \mathrm{~s} & \mathrm{I}_{\mathrm{E}} \mathrm{F}_{\mathrm{a}} \mathrm{S}_{\mathrm{a}}(0.2 & - & \\ \mathrm{V} / \mathrm{W}= & 0.0410 & & \mathrm{~V}=0.69 & 4452 & \mathrm{kN}\end{array}$

Dynamic Analysis Procedure
Required!

$F_{t}=\quad 379 \mathrm{KN}$

\begin{tabular}{|rrrrrrr|r|r|}
\hline Floor & \multicolumn{1}{c}{$\begin{array}{c}\mathrm{h}_{\mathrm{i}} \\
(\mathrm{m})\end{array}$} & $\begin{array}{c}\mathrm{h}_{\mathrm{x}} \\
(\mathrm{m})\end{array}$ & $\begin{array}{c}\mathrm{DL} \\
(\mathrm{kPa})\end{array}$ & $\begin{array}{c}\mathrm{A}_{\text {trib }} \\
\left(\mathrm{m}^{2}\right)\end{array}$ & $\begin{array}{c}\mathrm{W}_{\mathrm{x}} \\
(\mathrm{kN})\end{array}$ & $\mathrm{W}_{\mathrm{x}}{ }^{*} \mathrm{~h}_{\mathrm{x}}$ & \multicolumn{1}{c|}{$\begin{array}{c}\mathrm{F}_{\mathrm{x}} \\
(\mathrm{kN})\end{array}$} & $\begin{array}{r}\mathrm{M}_{\mathrm{x}} \\
(\mathrm{kN} . \mathrm{m})\end{array}$ \\
\hline ROOF & 3.65 & 45.00 & 5.46 & 853.00 & 4660 & 209689 & 710 & 2590 \\
\hline 12 & 3.65 & 41.35 & 10.93 & 853.00 & 9320 & 385361 & 607 & 7397 \\
\hline 11 & 3.65 & 37.70 & 10.93 & 853.00 & 9320 & 351345 & 554 & 14225 \\
\hline 10 & 3.65 & 34.05 & 10.93 & 853.00 & 9320 & 317329 & 500 & 22878 \\
\hline 9 & 3.65 & 30.40 & 10.93 & 853.00 & 9320 & 283313 & 446 & 33160 \\
\hline 8 & 3.65 & 26.75 & 10.93 & 853.00 & 9320 & 249297 & 393 & 43637 \\
\hline 7 & 3.65 & 23.10 & 10.93 & 853.00 & 9320 & 215280 & 339 & 54739 \\
\hline 6 & 3.65 & 19.45 & 10.93 & 853.00 & 9320 & 181264 & 286 & 66131 \\
\hline 5 & 3.65 & 15.80 & 10.93 & 853.00 & 9320 & 147248 & 232 & 77558 \\
\hline 4 & 3.65 & 12.15 & 10.93 & 853.00 & 9320 & 113232 & 178 & 88783 \\
\hline 3 & 3.65 & 8.50 & 10.93 & 853.00 & 9320 & 79216 & 125 & 99591 \\
\hline 2 & 4.85 & 4.85 & 12.54 & 853.00 & 10693 & 51861 & 82 & 112997 \\
\hline & 0 & 0 & & Sum $=$ & 108548 & 2584435 & 4452 & 112997
\end{tabular}


Project: H_SW_D

Location:

Montreal

Number: $\quad$ Model 2

$\mathrm{X}$

Direction: direction

Total Number of Floors, $\mathrm{N}_{\mathrm{TL}}=$

Climatic Data and Structural Parameters

\begin{tabular}{|c|c|c|c|c|c|c|c|c|c|}
\hline $\mathrm{q}$ & $\mathrm{S}_{\mathrm{a}}(0.2)$ & $\mathrm{S}_{\mathrm{a}}(0.5)$ & $\mathrm{S}_{\mathrm{a}}(1.0)$ & $\begin{array}{c}\mathrm{S}_{\mathrm{a}}(2.0 \\
)\end{array}$ & $\mathrm{PGA}$ & $\mathrm{F}_{\mathrm{a}}$ & $\mathrm{F}_{\mathrm{v}}$ & $\mathrm{M}_{\mathrm{v}}$ & $\mathrm{J}$ \\
\hline 0.42 & 0.594 & 0.373 & 0.194 & 0.092 & 0.303 & 1.2 & 1.3 & 1.600 & 0.500 \\
\hline
\end{tabular}

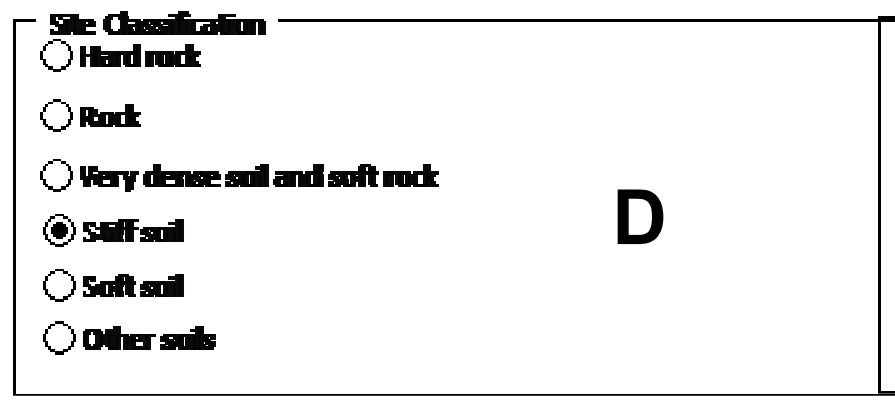

Iputarefactu
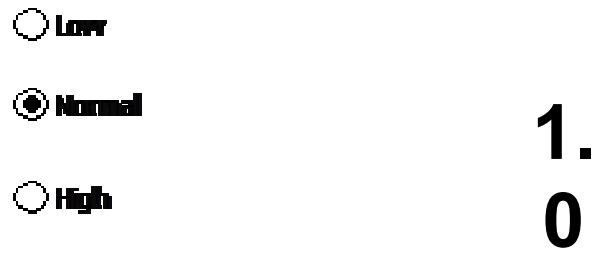

Oputare

\section{Theofsis}

Concrete _Ductile shear walls

$\begin{array}{llll}\mathrm{R}_{\mathrm{d}}= & 3.5 & \mathrm{R}_{\mathrm{o}}= & 1.6\end{array}$

$\begin{array}{rrrrrr}\mathrm{T}_{\mathrm{a}, \text { etabs }}= & 8.826 & \mathrm{~s} & \mathrm{~T}_{\mathrm{a}}= & 4.226 \mathrm{~s} \\ \mathrm{~T}_{\mathrm{a}, \text { code }}= & 2.113 & \mathrm{~s} & \mathrm{I}_{\mathrm{E}} \mathrm{F}_{\mathrm{a}} \mathrm{S}_{\mathrm{a}}(0.2 & & \\ \mathrm{V} / \mathrm{W}= & 0.0172 & \mathrm{~V}= & 0.69 & \\ & & \mathrm{~V}= & 6342 \mathrm{kN}\end{array}$

Dynamic Analysis Procedure Required!

$F_{t}=1586 \mathrm{KN}$

\begin{tabular}{|rrrrrrr|r|r|}
\hline Floor & $\begin{array}{c}\mathrm{h}_{\mathrm{i}} \\
(\mathrm{m})\end{array}$ & $\begin{array}{c}\mathrm{h} \\
(\mathrm{m})\end{array}$ & $\begin{array}{c}\mathrm{DL} \\
(\mathrm{kPa})\end{array}$ & $\begin{array}{c}\mathrm{A}_{\text {trib }} \\
\left(\mathrm{m}^{2}\right)\end{array}$ & $\begin{array}{c}\mathrm{W}_{\mathrm{x}} \\
(\mathrm{kN})\end{array}$ & $\mathrm{W}_{\mathrm{x}}{ }^{*} \mathrm{~h}_{\mathrm{x}}$ & $\begin{array}{c}\mathrm{F}_{\mathrm{x}} \\
(\mathrm{kN})\end{array}$ & $\begin{array}{r}\mathrm{M}_{\mathrm{x}} \\
(\mathrm{kN} . \mathrm{m})\end{array}$ \\
\hline ROOF & 3.65 & 147.20 & 5.46 & 853.00 & 4660 & 685915 & 1704 & 6218 \\
\hline 40 & 3.65 & 143.55 & 10.93 & 853.00 & 9320 & 1337814 & 230 & 13275 \\
\hline 39 & 3.65 & 139.90 & 10.93 & 853.00 & 9320 & 1303798 & 224 & 21151 \\
\hline 38 & 3.65 & 136.25 & 10.93 & 853.00 & 9320 & 1269782 & 218 & 29824 \\
\hline 37 & 3.65 & 132.60 & 10.93 & 853.00 & 9320 & 1235766 & 213 & 39272 \\
\hline 36 & 3.65 & 128.95 & 10.93 & 853.00 & 9320 & 1201750 & 207 & 49475 \\
\hline 35 & 3.65 & 125.30 & 10.93 & 853.00 & 9320 & 1167733 & 201 & 60411 \\
\hline 34 & 3.65 & 121.65 & 10.93 & 853.00 & 9320 & 1133717 & 195 & 72058 \\
\hline 33 & 3.65 & 118.00 & 10.93 & 853.00 & 9320 & 1099701 & 189 & 84395 \\
\hline 32 & 3.65 & 114.35 & 10.93 & 853.00 & 9320 & 1065685 & 183 & 97402 \\
\hline 31 & 3.65 & 110.70 & 10.93 & 853.00 & 9320 & 1031669 & 177 & 111055 \\
\hline 30 & 3.65 & 107.05 & 10.93 & 853.00 & 9320 & 997652 & 172 & 125335 \\
\hline 29 & 3.65 & 103.40 & 10.93 & 853.00 & 9320 & 963636 & 166 & 140220 \\
\hline 28 & 3.65 & 99.75 & 10.93 & 853.00 & 9320 & 929620 & 160 & 155689 \\
\hline 27 & 3.65 & 96.10 & 10.93 & 853.00 & 9320 & 895604 & 154 & 171719 \\
\hline
\end{tabular}




\begin{tabular}{|rrrrrrr|r|r|}
\hline 26 & 3.65 & 92.45 & 10.93 & 853.00 & 9320 & 861588 & 148 & 188290 \\
\hline 25 & 3.65 & 88.80 & 10.93 & 853.00 & 9320 & 827572 & 142 & 205381 \\
\hline 24 & 3.65 & 85.15 & 10.93 & 853.00 & 9320 & 793555 & 136 & 214361 \\
\hline 23 & 3.65 & 81.50 & 10.93 & 853.00 & 9320 & 759539 & 131 & 226748 \\
\hline 22 & 3.65 & 77.85 & 10.93 & 853.00 & 9320 & 725523 & 125 & 238808 \\
\hline 21 & 3.65 & 74.20 & 10.93 & 853.00 & 9320 & 691507 & 119 & 250493 \\
\hline 20 & 3.65 & 70.55 & 10.93 & 853.00 & 9320 & 657491 & 113 & 261757 \\
\hline 19 & 3.65 & 66.90 & 10.93 & 853.00 & 9320 & 623475 & 107 & 272556 \\
\hline 18 & 3.65 & 63.25 & 10.93 & 853.00 & 9320 & 589458 & 101 & 282849 \\
\hline 17 & 3.65 & 59.60 & 10.93 & 853.00 & 9320 & 555442 & 96 & 292594 \\
\hline 16 & 3.65 & 55.95 & 10.93 & 853.00 & 9320 & 521426 & 90 & 301754 \\
\hline 15 & 3.65 & 52.30 & 10.93 & 853.00 & 9320 & 487410 & 84 & 310291 \\
\hline 14 & 3.65 & 48.65 & 10.93 & 853.00 & 9320 & 453394 & 78 & 318171 \\
\hline 13 & 3.65 & 45.00 & 10.93 & 853.00 & 9320 & 419378 & 72 & 325359 \\
\hline 12 & 3.65 & 41.35 & 10.93 & 853.00 & 9320 & 385361 & 66 & 331825 \\
\hline 11 & 3.65 & 37.70 & 10.93 & 853.00 & 9320 & 351345 & 60 & 337539 \\
\hline 10 & 3.65 & 34.05 & 10.93 & 853.00 & 9320 & 317329 & 55 & 342472 \\
\hline 9 & 3.65 & 30.40 & 10.93 & 853.00 & 9320 & 283313 & 49 & 346599 \\
\hline 8 & 3.65 & 26.75 & 10.93 & 853.00 & 9320 & 249297 & 43 & 349895 \\
\hline 7 & 3.65 & 23.10 & 10.93 & 853.00 & 9320 & 215280 & 37 & 352337 \\
\hline 6 & 3.65 & 19.45 & 10.93 & 853.00 & 9320 & 181264 & 31 & 353904 \\
\hline 5 & 3.65 & 15.80 & 10.93 & 853.00 & 9320 & 147248 & 25 & 354577 \\
\hline 4 & 3.65 & 12.15 & 10.93 & 853.00 & 9320 & 113232 & 19 & 354339 \\
\hline 3 & 3.65 & 8.50 & 10.93 & 853.00 & 9320 & 79216 & 14 & 353174 \\
\hline 2 & 4.85 & 4.85 & 12.54 & 853.00 & 10693 & 51861 & 9 & 350169 \\
\hline & 0 & 0 & & $540=$ & 369494 & 27661345 & 6342 & 350169 \\
\hline
\end{tabular}


Project: L_SW_C

Location:

Montreal

Number: $\quad$ Model 3

$\mathrm{X}$

Direction: direction

Total Number of Floors, $\mathrm{N}_{\mathrm{TL}}=$

12

Climatic Data and Structural Parameters

\begin{tabular}{|c|c|c|c|c|c|c|c|c|c|}
\hline $\mathrm{q}$ & $\mathrm{S}_{\mathrm{a}}(0.2)$ & $\begin{array}{c}\mathrm{S}_{\mathrm{a}}(0.5 \\
)\end{array}$ & $\mathrm{S}_{\mathrm{a}}(1.0)$ & $\begin{array}{c}\mathrm{S}_{\mathrm{a}}(2.0 \\
)\end{array}$ & $\mathrm{PGA}$ & $\mathrm{F}_{\mathrm{a}}$ & $\mathrm{F}_{\mathrm{v}}$ & $\mathrm{M}_{\mathrm{v}}$ & $\mathrm{J}$ \\
\hline 0.42 & 0.594 & 0.373 & 0.194 & 0.092 & 0.303 & 1.2 & 1.3 & 1.043 & 0.809 \\
\hline
\end{tabular}
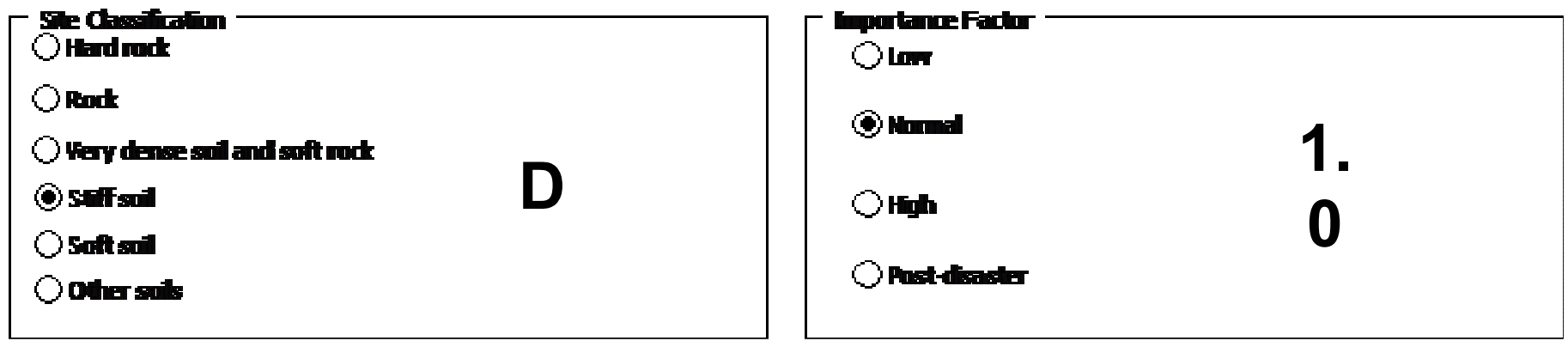

\section{Thpofsis}

Concrete_Conventional shear walls

$\begin{array}{llll}\mathrm{R}_{\mathrm{d}}= & 1.5 & \mathrm{R}_{\mathrm{o}}= & 1.3\end{array}$

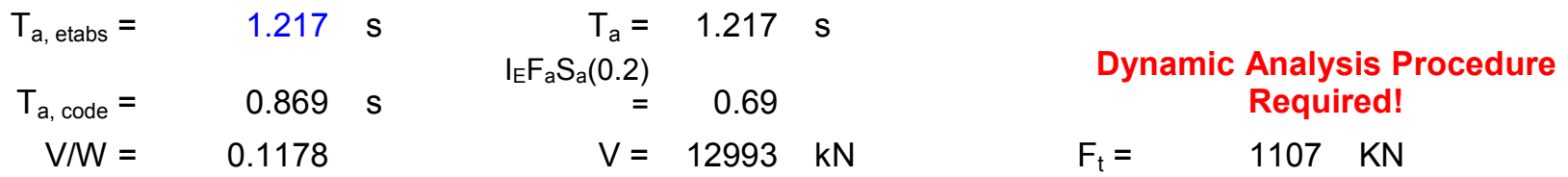

\begin{tabular}{|c|c|c|c|c|c|c|c|c|}
\hline Floor & $\begin{array}{l}h_{i} \\
(m)\end{array}$ & $\begin{array}{l}h_{x} \\
(m)\end{array}$ & $\begin{array}{c}\mathrm{DL} \\
(\mathrm{kPa})\end{array}$ & $\begin{array}{l}A_{\text {trib }} \\
\left(m^{2}\right)\end{array}$ & $\begin{array}{l}W_{x} \\
(k N)\end{array}$ & $W_{x}^{*} h_{x}$ & $\begin{array}{c}F_{x} \\
(k N)\end{array}$ & $\begin{array}{c}\mathrm{M}_{\mathrm{x}} \\
(\mathrm{kN} \cdot \mathrm{m})\end{array}$ \\
\hline ROOF & 3.65 & 45.00 & 7.53 & 853.00 & 6426 & 289150 & 2397 & 8749 \\
\hline 12 & 3.65 & 41.35 & 10.93 & 853.00 & 9320 & 385361 & 1719 & 23774 \\
\hline 11 & 3.65 & 37.70 & 10.93 & 853.00 & 9320 & 351345 & 1568 & 44521 \\
\hline 10 & 3.65 & 34.05 & 10.93 & 853.00 & 9320 & 317329 & 1416 & 70436 \\
\hline 9 & 3.65 & 30.40 & 10.93 & 853.00 & 9320 & 283313 & 1264 & 100964 \\
\hline 8 & 3.65 & 26.75 & 10.93 & 853.00 & 9320 & 249297 & 1112 & 131809 \\
\hline 7 & 3.65 & 23.10 & 10.93 & 853.00 & 9320 & 215280 & 961 & 164364 \\
\hline 6 & 3.65 & 19.45 & 10.93 & 853.00 & 9320 & 181264 & 809 & 197667 \\
\hline 5 & 3.65 & 15.80 & 10.93 & 853.00 & 9320 & 147248 & 657 & 230993 \\
\hline 4 & 3.65 & 12.15 & 10.93 & 853.00 & 9320 & 113232 & 505 & 263677 \\
\hline 3 & 3.65 & 8.50 & 10.93 & 853.00 & 9320 & 79216 & 353 & 295107 \\
\hline 2 & 4.85 & 4.85 & 12.54 & 853.00 & 10693 & 51861 & 231 & 334052 \\
\hline & 0 & 0 & & Sum $=$ & 110313 & 2663896 & 12993 & 334052 \\
\hline
\end{tabular}


Project: H_SW_C

Number: $\quad$ Model 4

Direction: $\quad \begin{aligned} & \mathbf{X} \\ & \text { direction }\end{aligned}$
Location:

Montreal

Total Number of Floors, $\mathrm{N}_{\mathrm{TL}}=$

40

Climatic Data and Structural Parameters

\begin{tabular}{|c|c|c|c|c|c|c|c|c|c|}
\hline $\mathrm{q}$ & $\mathrm{S}_{\mathrm{a}}(0.2)$ & $\mathrm{S}_{\mathrm{a}}(0.5)$ & $\mathrm{S}_{\mathrm{a}}(1.0)$ & $\begin{array}{c}\mathrm{S}_{\mathrm{a}}(2.0 \\
)\end{array}$ & $\mathrm{PGA}$ & $\mathrm{F}_{\mathrm{a}}$ & $\mathrm{F}_{\mathrm{v}}$ & $\mathrm{M}_{\mathrm{v}}$ & $\mathrm{J}$ \\
\hline 0.42 & 0.594 & 0.373 & 0.194 & 0.092 & 0.303 & 1.2 & 1.3 & 1.600 & 0.500 \\
\hline
\end{tabular}
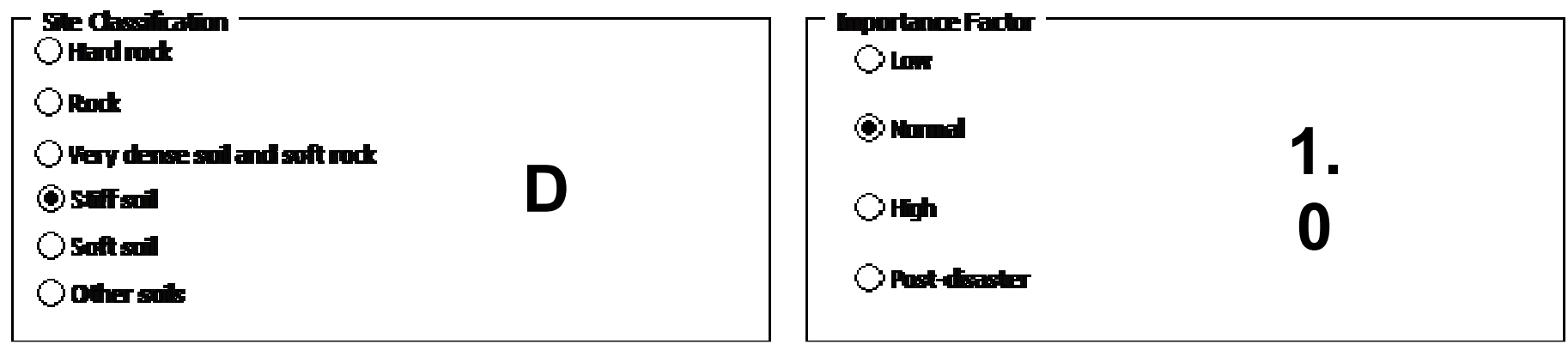

\section{Theofsis}

Concrete _Conventional shear walls
$\mathrm{R}_{\mathrm{d}}=$
1.5
$\mathrm{R}_{\mathrm{o}}=$
1.3

$\begin{array}{rrrrr}\mathrm{T}_{\mathrm{a}, \text { etabs }}= & 8.826 & \mathrm{~s} & \mathrm{~T}_{\mathrm{a}}= & 4.226 \mathrm{~s} \\ \mathrm{~T}_{\mathrm{a} \text {, code }}= & 2.113 & \mathrm{~s} & \mathrm{I}_{\mathrm{E}} \mathrm{F}_{\mathrm{a}} \mathrm{S}_{\mathrm{a}}(0.2 & \\ \mathrm{V} / \mathrm{W}= & 0.0493 & & \mathrm{~V}= & 18213 \mathrm{kN}\end{array}$

Dynamic Analysis Procedure Required!

$F_{t}=4553 \mathrm{KN}$

\begin{tabular}{|c|c|c|c|c|c|c|c|c|}
\hline Floor & $\begin{array}{l}\mathrm{h}_{\mathrm{i}} \\
(\mathrm{m})\end{array}$ & $\begin{array}{l}h_{x} \\
(m)\end{array}$ & $\begin{array}{c}\mathrm{DL} \\
(\mathrm{kPa})\end{array}$ & $\begin{array}{l}A_{\text {trib }} \\
\left(\mathrm{m}^{2}\right)\end{array}$ & $\begin{array}{l}W_{x} \\
(k N)\end{array}$ & $W_{x}{ }^{*} h_{x}$ & $\begin{array}{c}F_{x} \\
(k N)\end{array}$ & $\begin{array}{c}\mathrm{M}_{\mathrm{x}} \\
(\mathrm{kN} \cdot \mathrm{m})\end{array}$ \\
\hline ROOF & 3.65 & 147.20 & 5.46 & 853.00 & 4660 & 685915 & 4892 & 17856 \\
\hline 40 & 3.65 & 143.55 & 10.93 & 853.00 & 9320 & 1337814 & 661 & 38124 \\
\hline 39 & 3.65 & 139.90 & 10.93 & 853.00 & 9320 & 1303798 & 644 & 60741 \\
\hline 38 & 3.65 & 136.25 & 10.93 & 853.00 & 9320 & 1269782 & 627 & 85648 \\
\hline 37 & 3.65 & 132.60 & 10.93 & 853.00 & 9320 & 1235766 & 610 & 112782 \\
\hline 36 & 3.65 & 128.95 & 10.93 & 853.00 & 9320 & 1201750 & 593 & 142082 \\
\hline 35 & 3.65 & 125.30 & 10.93 & 853.00 & 9320 & 1167733 & 577 & 173487 \\
\hline 34 & 3.65 & 121.65 & 10.93 & 853.00 & 9320 & 1133717 & 560 & 206935 \\
\hline 33 & 3.65 & 118.00 & 10.93 & 853.00 & 9320 & 1099701 & 543 & 242366 \\
\hline 32 & 3.65 & 114.35 & 10.93 & 853.00 & 9320 & 1065685 & 526 & 279717 \\
\hline 31 & 3.65 & 110.70 & 10.93 & 853.00 & 9320 & 1031669 & 509 & 318928 \\
\hline 30 & 3.65 & 107.05 & 10.93 & 853.00 & 9320 & 997652 & 493 & 359938 \\
\hline 29 & 3.65 & 103.40 & 10.93 & 853.00 & 9320 & 963636 & 476 & 402684 \\
\hline
\end{tabular}




\begin{tabular}{|rrrrrrrr|r|}
\hline 28 & 3.65 & 99.75 & 10.93 & 853.00 & 9320 & 929620 & 459 & 447106 \\
\hline 27 & 3.65 & 96.10 & 10.93 & 853.00 & 9320 & 895604 & 442 & 493142 \\
\hline 26 & 3.65 & 92.45 & 10.93 & 853.00 & 9320 & 861588 & 425 & 540731 \\
\hline 25 & 3.65 & 88.80 & 10.93 & 853.00 & 9320 & 827572 & 409 & 589812 \\
\hline 24 & 3.65 & 85.15 & 10.93 & 853.00 & 9320 & 793555 & 392 & 615601 \\
\hline 23 & 3.65 & 81.50 & 10.93 & 853.00 & 9320 & 759539 & 375 & 651175 \\
\hline 22 & 3.65 & 77.85 & 10.93 & 853.00 & 9320 & 725523 & 358 & 685808 \\
\hline 21 & 3.65 & 74.20 & 10.93 & 853.00 & 9320 & 691507 & 341 & 719364 \\
\hline 20 & 3.65 & 70.55 & 10.93 & 853.00 & 9320 & 657491 & 325 & 751712 \\
\hline 19 & 3.65 & 66.90 & 10.93 & 853.00 & 9320 & 623475 & 308 & 782726 \\
\hline 18 & 3.65 & 63.25 & 10.93 & 853.00 & 9320 & 589458 & 291 & 812284 \\
\hline 17 & 3.65 & 59.60 & 10.93 & 853.00 & 9320 & 555442 & 274 & 840271 \\
\hline 16 & 3.65 & 55.95 & 10.93 & 853.00 & 9320 & 521426 & 257 & 866576 \\
\hline 15 & 3.65 & 52.30 & 10.93 & 853.00 & 9320 & 487410 & 241 & 891093 \\
\hline 14 & 3.65 & 48.65 & 10.93 & 853.00 & 9320 & 453394 & 224 & 913721 \\
\hline 13 & 3.65 & 45.00 & 10.93 & 853.00 & 9320 & 419378 & 207 & 934365 \\
\hline 12 & 3.65 & 41.35 & 10.93 & 853.00 & 9320 & 385361 & 190 & 952934 \\
\hline 11 & 3.65 & 37.70 & 10.93 & 853.00 & 9320 & 351345 & 174 & 969343 \\
\hline 10 & 3.65 & 34.05 & 10.93 & 853.00 & 9320 & 317329 & 157 & 983511 \\
\hline 9 & 3.65 & 30.40 & 10.93 & 853.00 & 9320 & 283313 & 140 & 995362 \\
\hline 8 & 3.65 & 26.75 & 10.93 & 853.00 & 9320 & 249297 & 123 & 1004827 \\
\hline 7 & 3.65 & 23.10 & 10.93 & 853.00 & 9320 & 215280 & 106 & 1011839 \\
\hline 6 & 3.65 & 19.45 & 10.93 & 853.00 & 9320 & 181264 & 90 & 1016340 \\
\hline 5 & 3.65 & 15.80 & 10.93 & 853.00 & 9320 & 147248 & 73 & 1018273 \\
\hline 4 & 3.65 & 12.15 & 10.93 & 853.00 & 9320 & 113232 & 56 & 1017589 \\
\hline 3 & 3.65 & 8.50 & 10.93 & 853.00 & 9320 & 79216 & 39 & 1014243 \\
\hline 2 & 4.85 & 4.85 & 12.54 & 853.00 & 10693 & 51861 & 26 & 1005614 \\
\hline & 0 & 0 & & $540=$ & 369494 & 27661345 & 18213 & 1005614 \\
\hline
\end{tabular}


Project: $\quad$ L_MF_D

Number: $\quad$ Model 5

$\mathrm{X}$

Direction: direction
Location:

Montreal

Total Number of Floors, $\mathrm{N}_{\mathrm{TL}}=$

Climatic Data and Structural Parameters

\begin{tabular}{|c|c|c|c|c|c|c|c|c|c|}
\hline $\mathrm{q}$ & $\mathrm{S}_{\mathrm{a}}(0.2)$ & $\begin{array}{c}\mathrm{S}_{\mathrm{a}}(0 . \\
5)\end{array}$ & $\mathrm{S}_{\mathrm{a}}(1.0)$ & $\begin{array}{c}\mathrm{S}_{\mathrm{a}}(2 . \\
0)\end{array}$ & $\mathrm{PGA}$ & $\mathrm{F}_{\mathrm{a}}$ & $\mathrm{F}_{\mathrm{v}}$ & $\mathrm{M}_{\mathrm{v}}$ & $\mathrm{J}$ \\
\hline 0.42 & 0.594 & 0.373 & 0.194 & 0.092 & 0.303 & 1.2 & 1.3 & 1.000 & 0.910 \\
\hline
\end{tabular}
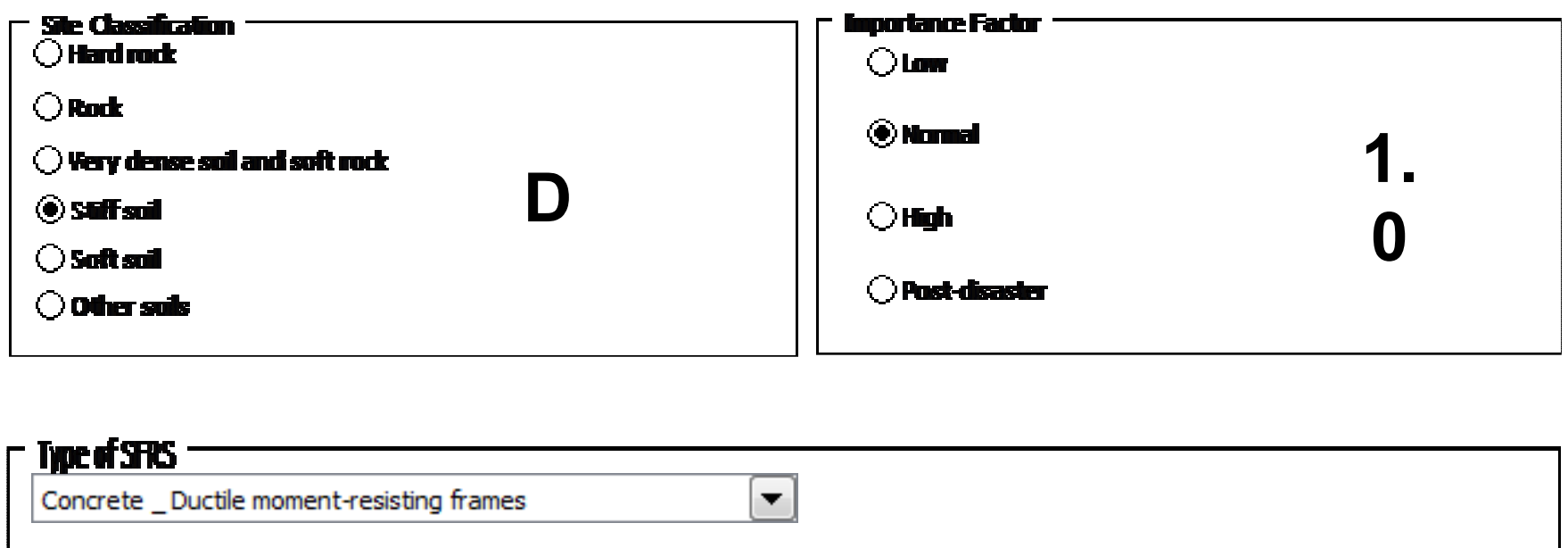
$\mathrm{R}_{\mathrm{d}}=$
4
$\mathrm{R}_{\mathrm{o}}=\quad 1.7$

$\begin{array}{rr}\mathrm{T}_{\mathrm{a}, \text { etabs }} & =1.854 \mathrm{~s} \\ \mathrm{~T}_{\mathrm{a}, \text { code }} & =1.303 \mathrm{~s} \\ \mathrm{~V} / \mathrm{W} & =0.0205\end{array}$
$\mathrm{T}_{\mathrm{a}}=1.854 \mathrm{~s}$ $\mathrm{I}_{\mathrm{E}} \mathrm{F}_{\mathrm{a}} \mathrm{S}_{\mathrm{a}}(0.2)$
$=0.69$
$V=2489 \mathrm{kN}$

Dynamic Analysis Procedure Required!

$F_{t}=\quad 323 \mathrm{KN}$

\begin{tabular}{|rrrrrrr|r|r|}
\hline Floor & $\begin{array}{c}\mathrm{h}_{\mathrm{i}} \\
(\mathrm{m})\end{array}$ & $\begin{array}{c}\mathrm{h}_{\mathrm{x}} \\
(\mathrm{m})\end{array}$ & $\begin{array}{c}\mathrm{DL} \\
(\mathrm{kPa})\end{array}$ & $\begin{array}{c}\mathrm{A}_{\text {trib }} \\
\left(\mathrm{m}^{2}\right)\end{array}$ & $\begin{array}{c}\mathrm{W}_{\mathrm{x}} \\
(\mathrm{kN})\end{array}$ & $\mathrm{W}_{\mathrm{x}}{ }^{*} \mathrm{~h}_{\mathrm{x}}$ & $\begin{array}{c}\mathrm{F}_{\mathrm{x}} \\
(\mathrm{kN})\end{array}$ & $\begin{array}{r}\mathrm{M}_{\mathrm{x}} \\
(\mathrm{kN} . \mathrm{m})\end{array}$ \\
\hline ROOF & 3.65 & 45.00 & 6.56 & 853.00 & 5592 & 251627 & 510 & 1861 \\
\hline 12 & 3.65 & 41.35 & 12.31 & 853.00 & 10497 & 434039 & 322 & 4896 \\
\hline 11 & 3.65 & 37.70 & 12.31 & 853.00 & 10497 & 395726 & 294 & 9004 \\
\hline 10 & 3.65 & 34.05 & 12.31 & 853.00 & 10497 & 357413 & 265 & 14079 \\
\hline 9 & 3.65 & 30.40 & 12.31 & 853.00 & 10497 & 319100 & 237 & 20019 \\
\hline 8 & 3.65 & 26.75 & 12.31 & 853.00 & 10497 & 280787 & 208 & 26370 \\
\hline 7 & 3.65 & 23.10 & 12.31 & 853.00 & 10497 & 242474 & 180 & 33215 \\
\hline 6 & 3.65 & 19.45 & 12.31 & 853.00 & 10497 & 204161 & 151 & 40412 \\
\hline 5 & 3.65 & 15.80 & 12.31 & 853.00 & 10497 & 165848 & 123 & 47843 \\
\hline 4 & 3.65 & 12.15 & 12.31 & 853.00 & 10497 & 127535 & 95 & 55394 \\
\hline 3 & 3.65 & 8.50 & 12.31 & 853.00 & 10497 & 89222 & 66 & 62956 \\
\hline 2 & 4.85 & 4.85 & 12.54 & 853.00 & 10693 & 51861 & 38 & 72837 \\
\hline & 0 & 0 & & Sum $=$ & 121252 & 2919790 & 2489 & 72837 \\
\hline
\end{tabular}


Project: H_MF_D

Number: $\quad$ Model 6

$\mathrm{X}$

Direction: direction
Location:

Montreal

Total Number of Floors, $\mathrm{N}_{\mathrm{TL}}=$

Climatic Data and Structural Parameters

\begin{tabular}{|c|c|c|c|c|c|c|c|c|c|}
\hline $\mathrm{q}$ & $\mathrm{S}_{\mathrm{a}}(0.2)$ & $\mathrm{S}_{\mathrm{a}}(0.5)$ & $\mathrm{S}_{\mathrm{a}}(1.0)$ & $\begin{array}{c}\mathrm{S}_{\mathrm{a}}(2 . \\
0)\end{array}$ & $\mathrm{PGA}$ & $\mathrm{F}_{\mathrm{a}}$ & $\mathrm{F}_{\mathrm{v}}$ & $\mathrm{M}_{\mathrm{v}}$ & $\mathrm{J}$ \\
\hline 0.42 & 0.594 & 0.373 & 0.194 & 0.092 & 0.303 & 1.2 & 1.3 & 1.000 & 0.900 \\
\hline
\end{tabular}
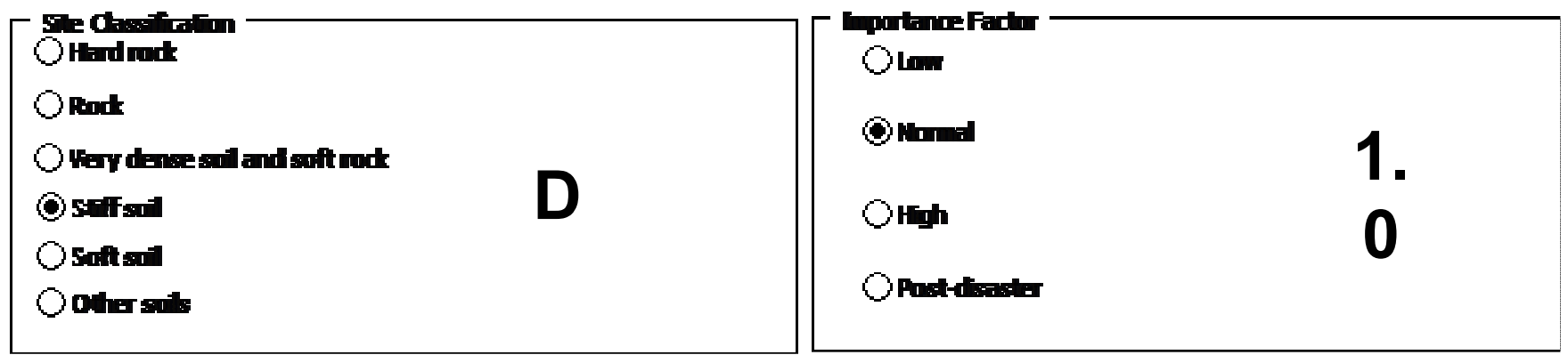

Theofsis

Concrete _ Ductile moment-resisting frames
$\mathrm{R}_{\mathrm{d}}=$
4
$\mathrm{R}_{\mathrm{o}}=$
1.7

\begin{tabular}{|c|c|c|c|c|c|c|}
\hline $\mathrm{T}_{\mathrm{a}, \text { etabs }}=$ & 7.382 & $\mathrm{~s}$ & $\begin{array}{r}\mathrm{T}_{\mathrm{a}}= \\
\mathrm{I}_{\mathrm{E}} \mathrm{F}_{\mathrm{a}} \mathrm{S}_{\mathrm{a}}(0 .\end{array}$ & 4.754 & s & \\
\hline $\mathrm{T}_{\mathrm{a}, \text { code }}=$ & 3.170 & $s$ & $2)=$ & 0.69 & & Dynamic Analysis Procedure Required! \\
\hline $\mathrm{V} / \mathrm{W}=$ & 0.0177 & & $V=$ & 7336 & $\mathrm{kN}$ & $1834 \mathrm{KN}$ \\
\hline
\end{tabular}

\begin{tabular}{|c|c|c|c|c|c|c|c|c|}
\hline Floor & $\begin{array}{l}\mathrm{h}_{\mathrm{i}} \\
(\mathrm{m})\end{array}$ & $\begin{array}{l}\mathrm{h}_{\mathrm{x}} \\
(\mathrm{m})\end{array}$ & $\begin{array}{c}\mathrm{DL} \\
(\mathrm{kPa})\end{array}$ & $\begin{array}{l}A_{\text {trib }} \\
\left(\mathrm{m}^{2}\right)\end{array}$ & $\begin{array}{l}W_{x} \\
(k N)\end{array}$ & $W_{x}{ }^{*} h_{x}$ & $\begin{array}{c}F_{x} \\
(k N)\end{array}$ & $\begin{array}{c}\mathrm{M}_{\mathrm{x}} \\
(\mathrm{kN} \cdot \mathrm{m})\end{array}$ \\
\hline ROOF & 3.65 & 147.20 & 6.56 & 853.00 & 5592 & 823098 & 1979 & 7224 \\
\hline 40 & 3.65 & 143.55 & 12.31 & 853.00 & 10497 & 1506801 & 266 & 15417 \\
\hline 39 & 3.65 & 139.90 & 12.31 & 853.00 & 10497 & 1468488 & 259 & 24555 \\
\hline 38 & 3.65 & 136.25 & 12.31 & 853.00 & 10497 & 1430175 & 252 & 34615 \\
\hline 37 & 3.65 & 132.60 & 12.31 & 853.00 & 10497 & 1391862 & 245 & 45569 \\
\hline 36 & 3.65 & 128.95 & 12.31 & 853.00 & 10497 & 1353549 & 239 & 57396 \\
\hline 35 & 3.65 & 125.30 & 12.31 & 853.00 & 10497 & 1315237 & 232 & 70068 \\
\hline 34 & 3.65 & 121.65 & 12.31 & 853.00 & 10497 & 1276924 & 225 & 83563 \\
\hline 33 & 3.65 & 118.00 & 12.31 & 853.00 & 10497 & 1238611 & 218 & 97855 \\
\hline 32 & 3.65 & 114.35 & 12.31 & 853.00 & 10497 & 1200298 & 212 & 112919 \\
\hline 31 & 3.65 & 110.70 & 12.31 & 853.00 & 10497 & 1161985 & 205 & 128731 \\
\hline 30 & 3.65 & 107.05 & 12.31 & 853.00 & 10497 & 1123672 & 198 & 145267 \\
\hline 29 & 3.65 & 103.40 & 12.31 & 853.00 & 10497 & 1085359 & 191 & 162501 \\
\hline 28 & 3.65 & 99.75 & 12.31 & 853.00 & 10497 & 1047046 & 185 & 180409 \\
\hline 27 & 3.65 & 96.10 & 12.31 & 853.00 & 10497 & 1008733 & 178 & 198966 \\
\hline
\end{tabular}




\begin{tabular}{|c|c|c|c|c|c|c|c|c|}
\hline 26 & 3.65 & 92.45 & 12.31 & 853.00 & 10497 & 970420 & 171 & 218148 \\
\hline 25 & 3.65 & 88.80 & 12.31 & 853.00 & 10497 & 932107 & 164 & 237930 \\
\hline 24 & 3.65 & 85.15 & 12.31 & 853.00 & 10497 & 893794 & 158 & 256292 \\
\hline 23 & 3.65 & 81.50 & 12.31 & 853.00 & 10497 & 855481 & 151 & 275885 \\
\hline 22 & 3.65 & 77.85 & 12.31 & 853.00 & 10497 & 817168 & 144 & 295822 \\
\hline 21 & 3.65 & 74.20 & 12.31 & 853.00 & 10497 & 778855 & 137 & 316073 \\
\hline 20 & 3.65 & 70.55 & 12.31 & 853.00 & 10497 & 740542 & 131 & 336608 \\
\hline 19 & 3.65 & 66.90 & 12.31 & 853.00 & 10497 & 702229 & 124 & 357397 \\
\hline 18 & 3.65 & 63.25 & 12.31 & 853.00 & 10497 & 663916 & 117 & 378411 \\
\hline 17 & 3.65 & 59.60 & 12.31 & 853.00 & 10497 & 625603 & 110 & 399619 \\
\hline 16 & 3.65 & 55.95 & 12.31 & 853.00 & 10497 & 587290 & 104 & 420995 \\
\hline 15 & 3.65 & 52.30 & 12.31 & 853.00 & 10497 & 548977 & 97 & 442509 \\
\hline 14 & 3.65 & 48.65 & 12.31 & 853.00 & 10497 & 510664 & 90 & 464134 \\
\hline 13 & 3.65 & 45.00 & 12.31 & 853.00 & 10497 & 472352 & 83 & 485842 \\
\hline 12 & 3.65 & 41.35 & 12.31 & 853.00 & 10497 & 434039 & 77 & 507606 \\
\hline 11 & 3.65 & 37.70 & 12.31 & 853.00 & 10497 & 395726 & 70 & 529400 \\
\hline 10 & 3.65 & 34.05 & 12.31 & 853.00 & 10497 & 357413 & 63 & 551197 \\
\hline 9 & 3.65 & 30.40 & 12.31 & 853.00 & 10497 & 319100 & 56 & 572972 \\
\hline 8 & 3.65 & 26.75 & 12.31 & 853.00 & 10497 & 280787 & 50 & 594699 \\
\hline 7 & 3.65 & 23.10 & 12.31 & 853.00 & 10497 & 242474 & 43 & 616354 \\
\hline 6 & 3.65 & 19.45 & 12.31 & 853.00 & 10497 & 204161 & 36 & 637911 \\
\hline 5 & 3.65 & 15.80 & 12.31 & 853.00 & 10497 & 165848 & 29 & 659347 \\
\hline 4 & 3.65 & 12.15 & 12.31 & 853.00 & 10497 & 127535 & 22 & 680637 \\
\hline 3 & 3.65 & 8.50 & 12.31 & 853.00 & 10497 & 89222 & 16 & 701759 \\
\hline 2 & 4.85 & 4.85 & 12.54 & 853.00 & 10693 & 51861 & 9 & 729523 \\
\hline & 0 & 0 & & Sum $=$ & 415159 & 31199400 & 7336 & 729523 \\
\hline
\end{tabular}


Project: $\quad$ L_MF_C

Number: $\quad$ Model 7

$\mathrm{X}$

Direction: direction
Location:

Montreal

Total Number of Floors, $\mathrm{N}_{\mathrm{TL}}=$

Climatic Data and Structural Parameters

\begin{tabular}{|c|c|c|c|c|c|c|c|c|c|}
\hline $\mathrm{q}$ & $\mathrm{S}_{\mathrm{a}}(0.2)$ & $\begin{array}{c}\mathrm{S}_{\mathrm{a}}(0 . \\
5)\end{array}$ & $\mathrm{S}_{\mathrm{a}}(1.0)$ & $\begin{array}{c}\mathrm{S}_{\mathrm{a}}(2 . \\
0)\end{array}$ & $\mathrm{PGA}$ & $\mathrm{F}_{\mathrm{a}}$ & $\mathrm{F}_{\mathrm{v}}$ & $\mathrm{M}_{\mathrm{v}}$ & $\mathrm{J}$ \\
\hline 0.42 & 0.594 & 0.373 & 0.194 & 0.092 & 0.303 & 1.2 & 1.3 & 1.000 & 0.910 \\
\hline
\end{tabular}
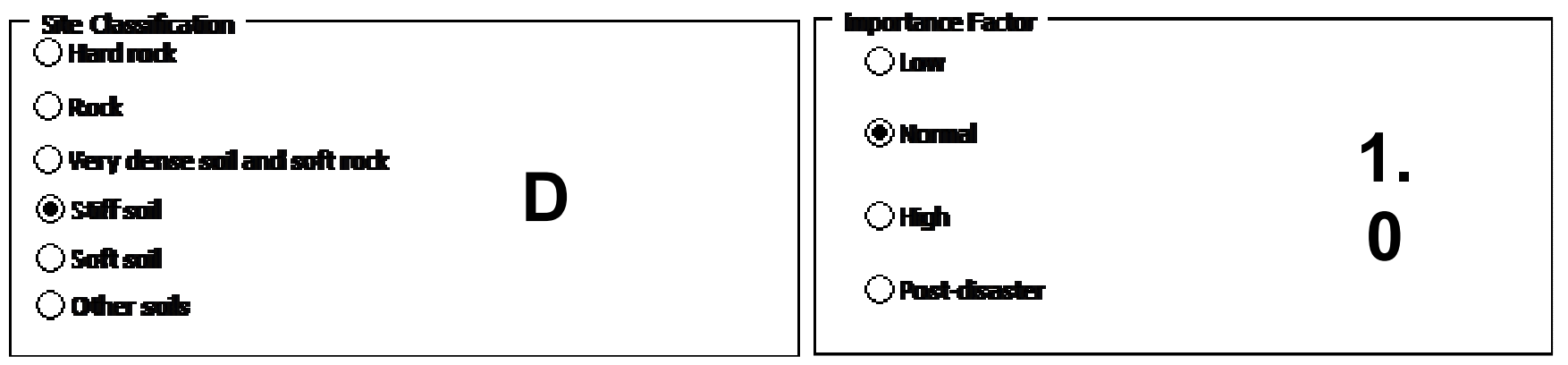

The of sts

Concrete _Conventional moment-resisting frames

$\begin{array}{llll}\mathrm{R}_{\mathrm{d}}= & 1.5 & \mathrm{R}_{\mathrm{o}}= & 1.3\end{array}$

$\begin{array}{rrrrrrr}\mathrm{T}_{\mathrm{a} \text {, etabs }}= & 1.854 & \mathrm{~s} & \mathrm{~T}_{\mathrm{a}}= & 1.854 \mathrm{~s} & \\ \mathrm{~T}_{\mathrm{a} \text {, code }}= & 1.303 & \mathrm{~s} & \mathrm{I}_{\mathrm{E}} \mathrm{F}_{\mathrm{a}} \mathrm{S}_{\mathrm{a}}(0.2) & = & 0.69 & \\ \mathrm{~V} / \mathrm{V}= & 0.0716 & \mathrm{~V}= & 8680 \mathrm{kN} & \text { Dynamic Analysis Procedure Required! }\end{array}$

\begin{tabular}{|c|c|c|c|c|c|c|c|c|}
\hline Floor & $\begin{array}{l}\mathrm{h}_{\mathrm{i}} \\
(\mathrm{m})\end{array}$ & $\begin{array}{l}\mathrm{h}_{\mathrm{x}} \\
(\mathrm{m})\end{array}$ & $\begin{array}{c}\mathrm{DL} \\
(\mathrm{kPa})\end{array}$ & $\begin{array}{l}A_{\text {trib }} \\
\left(m^{2}\right)\end{array}$ & $\begin{array}{l}W_{x} \\
(k N)\end{array}$ & $W_{x}{ }^{*} h_{x}$ & $\begin{array}{c}F_{x} \\
(k N)\end{array}$ & $\begin{array}{c}\mathrm{M}_{\mathrm{x}} \\
(\mathrm{kN} \cdot \mathrm{m})\end{array}$ \\
\hline ROOF & 3.65 & 45.00 & 6.56 & 853.00 & 5592 & 251627 & 1778 & 6488 \\
\hline 12 & 3.65 & 41.35 & 12.31 & 853.00 & 10497 & 434039 & 1123 & 17075 \\
\hline 11 & 3.65 & 37.70 & 12.31 & 853.00 & 10497 & 395726 & 1024 & 31398 \\
\hline 10 & 3.65 & 34.05 & 12.31 & 853.00 & 10497 & 357413 & 925 & 49097 \\
\hline 9 & 3.65 & 30.40 & 12.31 & 853.00 & 10497 & 319100 & 826 & 69809 \\
\hline 8 & 3.65 & 26.75 & 12.31 & 853.00 & 10497 & 280787 & 726 & 91957 \\
\hline 7 & 3.65 & 23.10 & 12.31 & 853.00 & 10497 & 242474 & 627 & 115826 \\
\hline 6 & 3.65 & 19.45 & 12.31 & 853.00 & 10497 & 204161 & 528 & 140924 \\
\hline 5 & 3.65 & 15.80 & 12.31 & 853.00 & 10497 & 165848 & 429 & 166837 \\
\hline 4 & 3.65 & 12.15 & 12.31 & 853.00 & 10497 & 127535 & 330 & 193169 \\
\hline 3 & 3.65 & 8.50 & 12.31 & 853.00 & 10497 & 89222 & 231 & 219540 \\
\hline 2 & 4.85 & 4.85 & 12.54 & 853.00 & 10693 & 51861 & 134 & 253996 \\
\hline & 0 & 0 & & Sum $=$ & 121252 & 2919790 & 8680 & 253996 \\
\hline
\end{tabular}


Project: H_MF_C

Number: $\quad$ Model 8

$\mathrm{X}$

Direction: direction
Location:

Montreal

Total Number of Floors, $\mathrm{N}_{\mathrm{TL}}=$

Climatic Data and Structural Parameters

\begin{tabular}{|c|c|c|c|c|c|c|c|c|c|}
\hline $\mathrm{q}$ & $\mathrm{S}_{\mathrm{a}}(0.2)$ & $\mathrm{S}_{\mathrm{a}}(0.5)$ & $\mathrm{S}_{\mathrm{a}}(1.0)$ & $\begin{array}{c}\mathrm{S}_{\mathrm{a}}(2.0 \\
)\end{array}$ & $\mathrm{PGA}$ & $\mathrm{F}_{\mathrm{a}}$ & $\mathrm{F}_{\mathrm{v}}$ & $\mathrm{M}_{\mathrm{v}}$ & $\mathrm{J}$ \\
\hline 0.42 & 0.594 & 0.373 & 0.194 & 0.092 & 0.303 & 1.2 & 1.3 & 1.000 & 0.900 \\
\hline
\end{tabular}
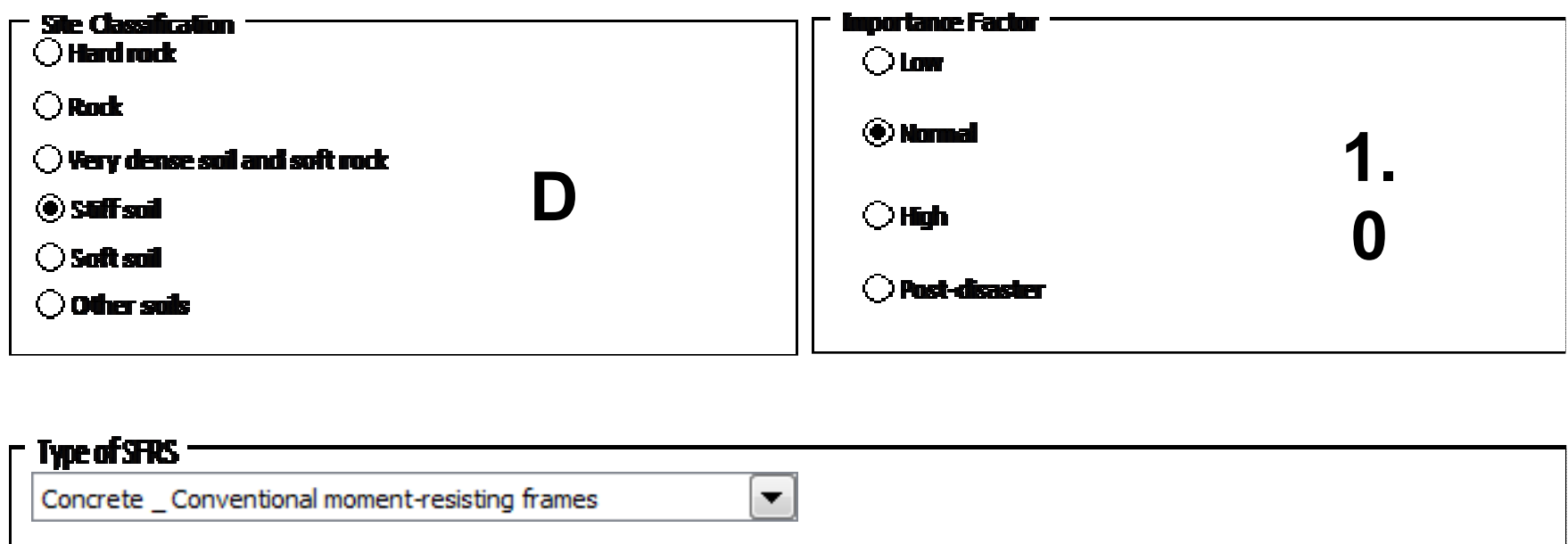
$\mathrm{R}_{\mathrm{d}}=$
1.5
$\mathrm{R}_{\mathrm{o}}=$
1.3

$\begin{array}{rrrrr}\mathrm{T}_{\mathrm{a} \text {, etabs }}= & 7.382 & \mathrm{~s} & \mathrm{~T}_{\mathrm{a}}= & 4.754 \mathrm{~s} \\ \mathrm{~T}_{\mathrm{a} \text {, code }}= & 3.170 & \mathrm{~s} & \mathrm{I}_{\mathrm{E}} \mathrm{F}_{\mathrm{a}} \mathrm{S}_{\mathrm{a}}(0) & 0.69 \\ \mathrm{~V} / \mathrm{V}= & 0.0616 & \mathrm{~V}) & \mathrm{V}= & 25581 \mathrm{kN}\end{array}$

Dynamic Analysis Procedure Required! $F_{t}=6395 \mathrm{KN}$

\begin{tabular}{|c|c|c|c|c|c|c|c|c|}
\hline Floor & $\begin{array}{l}\mathrm{h}_{\mathrm{i}} \\
(\mathrm{m})\end{array}$ & $\begin{array}{l}\mathrm{h}_{\mathrm{x}} \\
(\mathrm{m})\end{array}$ & $\begin{array}{c}\mathrm{DL} \\
(\mathrm{kPa})\end{array}$ & $\begin{array}{l}A_{\text {trib }} \\
\left(m^{2}\right)\end{array}$ & $\begin{array}{l}W_{x} \\
(k N)\end{array}$ & $W_{x}^{*} h_{x}$ & $\begin{array}{c}F_{x} \\
(k N)\end{array}$ & $\begin{array}{c}\mathrm{M}_{\mathrm{x}} \\
(\mathrm{kN} \cdot \mathrm{m})\end{array}$ \\
\hline ROOF & 3.65 & 147.20 & 6.56 & 853.00 & 5592 & 823098 & 6901 & 25190 \\
\hline 40 & 3.65 & 143.55 & 12.31 & 853.00 & 10497 & 1506801 & 927 & 53762 \\
\hline 39 & 3.65 & 139.90 & 12.31 & 853.00 & 10497 & 1468488 & 903 & 85629 \\
\hline 38 & 3.65 & 136.25 & 12.31 & 853.00 & 10497 & 1430175 & 879 & 120707 \\
\hline 37 & 3.65 & 132.60 & 12.31 & 853.00 & 10497 & 1391862 & 856 & 158909 \\
\hline 36 & 3.65 & 128.95 & 12.31 & 853.00 & 10497 & 1353549 & 832 & 200149 \\
\hline 35 & 3.65 & 125.30 & 12.31 & 853.00 & 10497 & 1315237 & 809 & 244341 \\
\hline 34 & 3.65 & 121.65 & 12.31 & 853.00 & 10497 & 1276924 & 785 & 291399 \\
\hline 33 & 3.65 & 118.00 & 12.31 & 853.00 & 10497 & 1238611 & 762 & 341237 \\
\hline 32 & 3.65 & 114.35 & 12.31 & 853.00 & 10497 & 1200298 & 738 & 393769 \\
\hline 31 & 3.65 & 110.70 & 12.31 & 853.00 & 10497 & 1161985 & 715 & 448909 \\
\hline 30 & 3.65 & 107.05 & 12.31 & 853.00 & 10497 & 1123672 & 691 & 506571 \\
\hline 29 & 3.65 & 103.40 & 12.31 & 853.00 & 10497 & 1085359 & 667 & 566670 \\
\hline 28 & 3.65 & 99.75 & 12.31 & 853.00 & 10497 & 1047046 & 644 & 629118 \\
\hline 27 & 3.65 & 96.10 & 12.31 & 853.00 & 10497 & 1008733 & 620 & 693830 \\
\hline
\end{tabular}




\begin{tabular}{|c|c|c|c|c|c|c|c|c|}
\hline 26 & 3.65 & 92.45 & 12.31 & 853.00 & 10497 & 970420 & 597 & 760721 \\
\hline 25 & 3.65 & 88.80 & 12.31 & 853.00 & 10497 & 932107 & 573 & 829704 \\
\hline 24 & 3.65 & 85.15 & 12.31 & 853.00 & 10497 & 893794 & 550 & 893738 \\
\hline 23 & 3.65 & 81.50 & 12.31 & 853.00 & 10497 & 855481 & 526 & 962060 \\
\hline 22 & 3.65 & 77.85 & 12.31 & 853.00 & 10497 & 817168 & 503 & 1031585 \\
\hline 21 & 3.65 & 74.20 & 12.31 & 853.00 & 10497 & 778855 & 479 & 1102204 \\
\hline 20 & 3.65 & 70.55 & 12.31 & 853.00 & 10497 & 740542 & 455 & 1173814 \\
\hline 19 & 3.65 & 66.90 & 12.31 & 853.00 & 10497 & 702229 & 432 & 1246308 \\
\hline 18 & 3.65 & 63.25 & 12.31 & 853.00 & 10497 & 663916 & 408 & 1319586 \\
\hline 17 & 3.65 & 59.60 & 12.31 & 853.00 & 10497 & 625603 & 385 & 1393545 \\
\hline 16 & 3.65 & 55.95 & 12.31 & 853.00 & 10497 & 587290 & 361 & 1468085 \\
\hline 15 & 3.65 & 52.30 & 12.31 & 853.00 & 10497 & 548977 & 338 & 1543108 \\
\hline 14 & 3.65 & 48.65 & 12.31 & 853.00 & 10497 & 510664 & 314 & 1618518 \\
\hline 13 & 3.65 & 45.00 & 12.31 & 853.00 & 10497 & 472352 & 290 & 1694218 \\
\hline 12 & 3.65 & 41.35 & 12.31 & 853.00 & 10497 & 434039 & 267 & 1770113 \\
\hline 11 & 3.65 & 37.70 & 12.31 & 853.00 & 10497 & 395726 & 243 & 1846112 \\
\hline 10 & 3.65 & 34.05 & 12.31 & 853.00 & 10497 & 357413 & 220 & 1922124 \\
\hline 9 & 3.65 & 30.40 & 12.31 & 853.00 & 10497 & 319100 & 196 & 1998057 \\
\hline 8 & 3.65 & 26.75 & 12.31 & 853.00 & 10497 & 280787 & 173 & 2073823 \\
\hline 7 & 3.65 & 23.10 & 12.31 & 853.00 & 10497 & 242474 & 149 & 2149337 \\
\hline 6 & 3.65 & 19.45 & 12.31 & 853.00 & 10497 & 204161 & 126 & 2224510 \\
\hline 5 & 3.65 & 15.80 & 12.31 & 853.00 & 10497 & 165848 & 102 & 2299261 \\
\hline 4 & 3.65 & 12.15 & 12.31 & 853.00 & 10497 & 127535 & 78 & 2373504 \\
\hline 3 & 3.65 & 8.50 & 12.31 & 853.00 & 10497 & 89222 & 55 & 2447161 \\
\hline 2 & 4.85 & 4.85 & 12.54 & 853.00 & 10693 & 51861 & 32 & 2543979 \\
\hline & 0 & 0 & & Sum $=$ & 415159 & 31199400 & 25581 & 2543979 \\
\hline
\end{tabular}




\section{References}

[1] Adams, J., and Atkinson, G. (2003). Development of seismic hazard maps for the proposed 2005 edition of the National Building Code of Canada. Canadian Journal of Civil Engineering, 30: 255-271.

[2] Heidebrecht, C. (2003). Overview of seismic provisions of the proposed 2005 edition of the National Building Code of Canada. Canadian Journal of Civil Engineering, 30:241-254.

[3] Humar, J., Adams, J., Tremblay, R., Rogers, C.A., and Halchuk, S. (2010). Proposals for the seismic design provisions of the 2010 National Building Code of Canada. Proceedings of the $9^{\text {th }}$ U.S. National and $10^{\text {th }}$ Canaidan Conference on Earthquake Engineering. Paper No. 1387.

[4] Humar, J. (2015). Background to some of the seismic design provisions of the 2015 National Building Code of Canada. Canadian Journal of Civil Engineering, 42: 940-952.

[5] Mitchell, D., Tremblay, R., Karacabeyli, E., Paultre, P., Saatcioglu, M., and Donald, L.A. (2003). Seismic force modification factors for the proposed 2005 edition of the National Building Code of Canada. Canadian Journal of Civil Engineering, 30: 308-327.

[6] Mitchell, D., Paultre, P., Tinawi, R., Saatcioglu, M., Tremblay, R., Elwood, K.J., Adams, J., and Devall, R. (2010). Evolution of seismic design provisions in the National Building Code of Canada. Canadian Journal of Civil Engineering, 37: 1157-1170.

[7] Saatcioglu, M., Humar, J. (2003). Dynamic analysis of buildings for earthquake-resistant design. Canadian Journal of Civil Engineering, 30: 338-359.

[8] Taranath, B. (2005). Wind and earthquake resistant buildings. New York: Dekker.

[9] Mwafy, A. M. and Elnashai, A. S.(2002). Calibration of force reduction factors of RC buildings. Journal of Earthquake Engineering, 6: 2, 239 - 273

[10] Gutierrez, G (2003).Complementary Technical Norms for Earthquake Resistant Design.

[11] American Society of Civil Engineers, ASCE Standard 7-10. Minimum Design Loads for 
Buildings and Other Structures. Virginia: ASCE/AEI, 2013.

[12] Architectural Institute of Japan (ed.), Preliminary Reconnaissance Report of the 2011 TohokuChiho Taiheiyo-Oki Earthquake, Geotechnical, Geological and Earthquake Engineering 23, DOI 10.1007/978-4-431-54097-7, (C) Springer Japan 2012

[13] Canadian Standards Association.(2014). CSA A23.3-14. Design of concrete structures.

[14] British Standards Institution. (2004). Eurocode 8: Design provisions for earthquake resistance of structures. London: British Standards Institution.

[15] Ali, Mir M., and Kyoung Sun Moon. "Structural Developments In Tall Buildings: Current Trends And Future Prospects". Architectural Science Review 50.3 (2007): 205-223. Web.

[16] Canadian Commission on Building and Fire Codes. (2015). The National Building Code of Canada 2015.NRC 